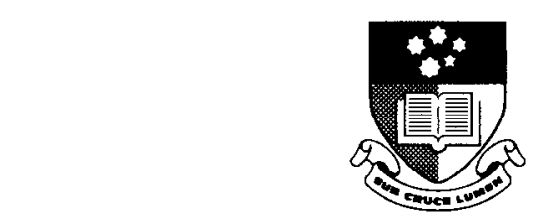

THE UNIVERSITY OF ADELAIDE

\title{
THE ETHICS OF JAPAN'S GLOBAL
}

\section{ENVIRONMENTAL POLICY}

\author{
By
}

\section{Midori Kagawa-Fox}

\section{B.A. Honours (International Relations) (Flinders University)} M.A (International Relations) (Flinders University)

Thesis submitted for the degree of Doctor of Philosophy in Asian Studies

School of Social Sciences

University of Adelaide

October 2009 


\section{TABLE OF CONTENTS}

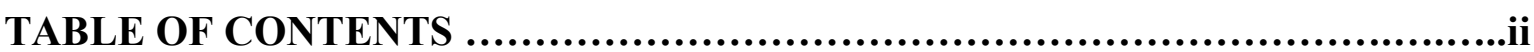

LIST OF TABLES, GRAPHS, FIGURES AND A MAP ............................vi

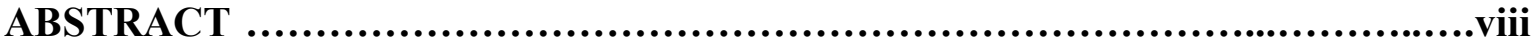

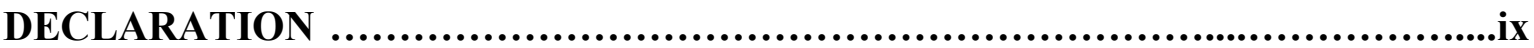

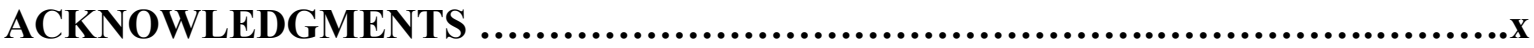

WORK RELATED TO THIS THESIS ........................................... xiii

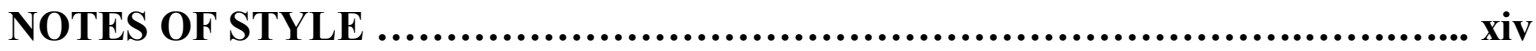

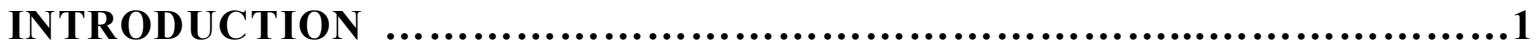

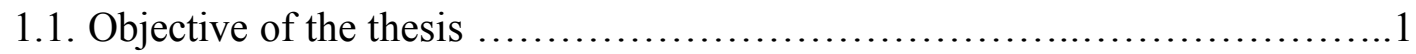

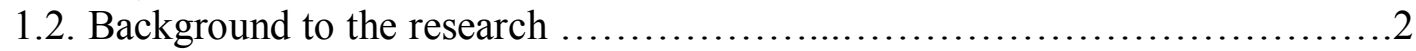

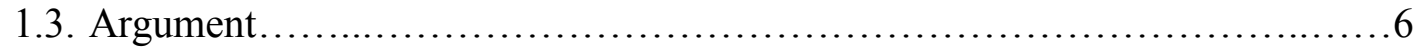

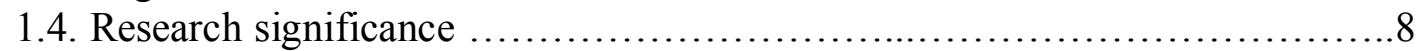

1.5. Methodology .......................................................... 11

1.6. Outline of the thesis ..................................................... 16

CHAPTER ONE: WESTERN AND JAPANESE

ENVIRONMENTAL ETHICS, Environment, culture and morals .............19

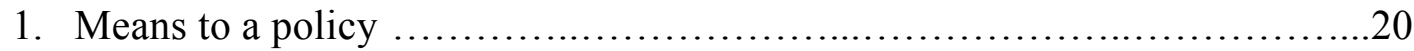

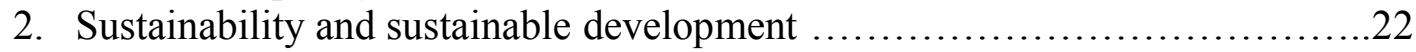

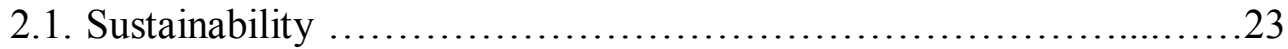

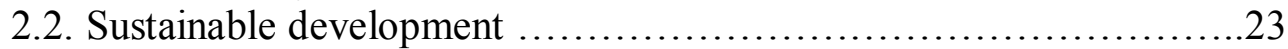

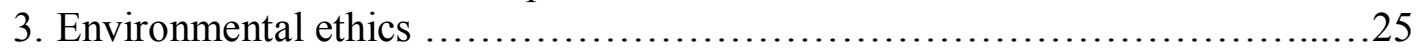

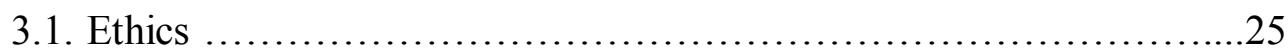

3.2. Environmental ethics - the beginnings ..........................27

3.3. Environmental ethics - a basic understanding .....................28

3.4. The development of a 'new' environmental ethics ................... 30

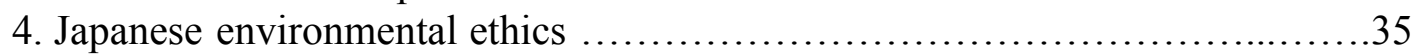

4.1. Japanese Rinri and Nihonjinron ................................36

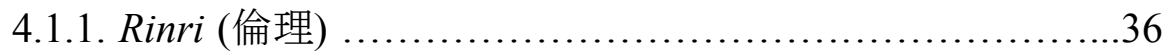

4.1.2. Nihonjinron (Japanese characteristics) .......................38

4.2. Japanese thinkers .............................................39

4.3. The effect of religion on the Japanese environmental consciousness

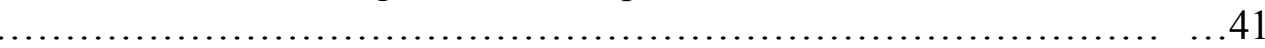

4.4. The Japanese and animal....................................... 44

4.5. Minamata-gaku .................................................46

4.6. A comparison of the two models - development and outcome ....... 50

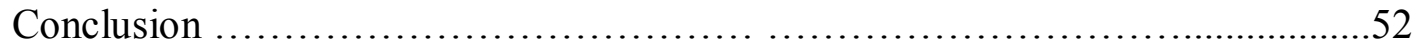


1. Japan's Kögai cases ....................................................55

1.1. Itai-itai disease .................................................

1.2. Minamata disease in Minamata City and Niigata City ................57

1.3. Yokkaichi asthma ...............................................60

2. The development of the domestic environmental policy ......................66

2.1. Kōgai, environmental pollution (1945-1971) .......................61

2.2. From Kōgai to Kayokyō (environment) (1971-1989) ..................65

2.3. From the domestic to the global environment (1990-) ...............67

3. The trio behind Japan's domestic environmental policy .......................70

3.1. The Environmental Agency (1971-2000) and the

Ministry of the Environment (2001-) ................................71

3.2. The Ministry of International Trade and Industry (1949-2000),

Renamed the Ministry of Economy, Trade and Industry (2001-).........75

3.3. Nippon Keidanren (Japan Business Federation) ......................77

4. Japan's domestic environment policy approach ......................... 80

4.1. Sustainable society - 国民運動 (Kokumin undō: National movement

............................................................. 80

4.2. Global environmental focus .................................... 82

4.3. Technological solutions ......................................... 83

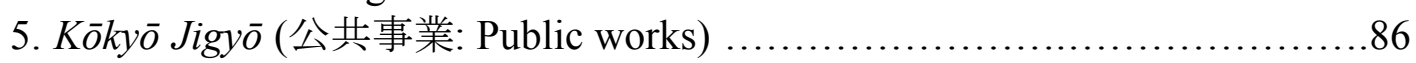

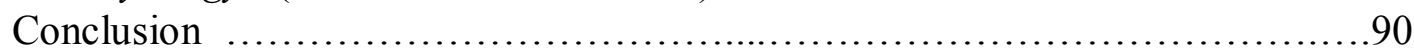

CHAPTER THREE: JAPAN'S GLOBAL ENVIRONMENT POLICY ..............91

1. Japan's global environmental policy development .........................992

1.1. Rio de Janeiro .................................................... 94

1.2. Basic Environment Law .........................................95

1.3. Kyoto Conference ............................................ 96

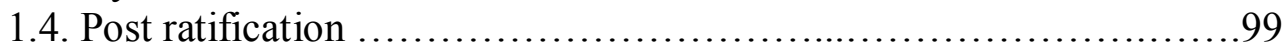

2. The trio behind the GEP ............................................. 100

2.1. The Ministry of the Environment .............................101

2.2. The Ministry of Foreign Affairs ...................................104

2.3. Ministry of Economy, Trade and Industry ........................105

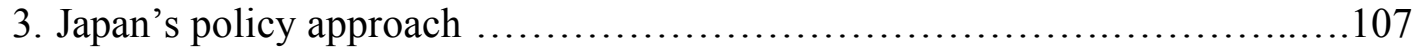

3.1. Japan's Business Community ....................................107

3.2. Environmental ODA ..........................................113

3.3. Environmental technology ........................................119

Conclusion ....

\section{CASE STUDIES:}

CHAPTER FOUR: Case study 1

THE WHALING POLICY, Whales and whaling, a cultural or ethical conflict?......122

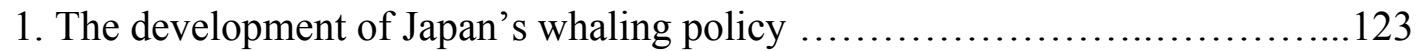

1.1. The period prior to World War II. ................................123 


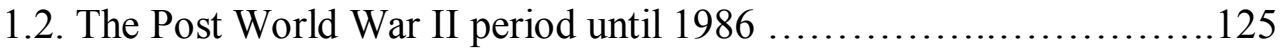

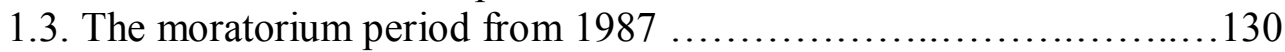

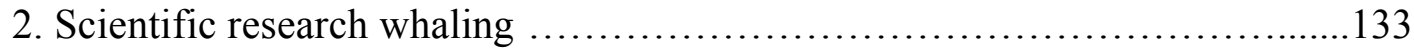

2.1. The legitimacy of the research ....................................133

2.2. Concerns over the quality of Japan's scientific research ..............136

3. The trio behind the Japanese whaling policy .................................140

3.1. The Fisheries Agency - The role of the Hogei-han ..................141

3.2. The Institute of Cetacean Research ...............................143

3.3. Nippon Dai Suisan Kai (Japan Fisheries Association) ..................145

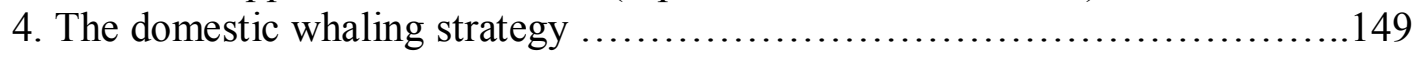

5. Question of the ethics of Japan's whaling policy .......................... 153

5.1. The ethics of scientific whaling .............................. 154

5.2. The Whaling Triangle - distribution network .........................157

Conclusion

\section{CHAPTER FIVE: Case study 2}

NUCLEAR ENERGY POLICY, The ethics of using nuclear energy .....................161

1. The development of Japan's nuclear power policy .........................162

1.1. Foundation of Japan's Nuclear Power Program (NPP)

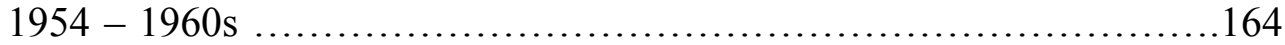

1.2. Energy demand (1970s - mid 1980s) ........................... 168

1.3. The global environment and nuclear energy (1990-) ...............170

1.4. Sustainable supply and environmental preservation (2001-) .........172

2. Concerns: Japan's nuclear power facilities ............................... 173

2.1. Mishaps at nuclear facilities ...................................174

2.2. The Tokaimura nuclear facility accident ........................176

2.2.1. The nature of the accident ...........................176

2.2.2. Tokaimura's dilemma .................................... 178

3. The power behind Japan's nuclear power development .....................179

3.1. Genshiryoku Iin'kai -

The Atomic Energy Commission of Japan ...............................................180

3.2. Science and Technology Policy Bureau under the MEXT ............182

3.3. Agency for Natural Resources and Energy under the METI ..........183

3.4. Japan Atomic Industrial Forum Inc. ..............................184

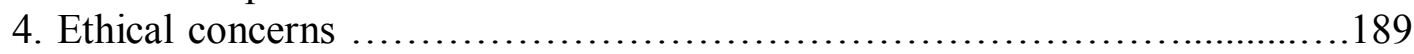

4.1. The focus of Japan's nuclear energy policy ......................190

4.2. Nuclear waste ...................................................192

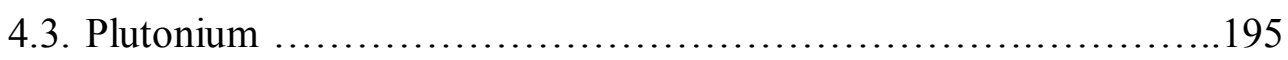

4.4. Nuclear weapons ............................................ 197

4.5. Environmental concerns ........................................ 199

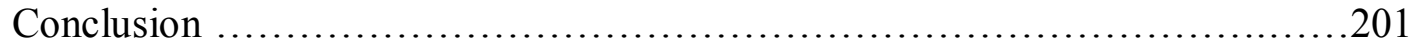

\section{CHAPTER SIX: Case study 3}

FORESTRY AND TIMBER TRADE POLICY, Practice, principles, ethics ............203

1. The development of Japan's forestry policy .........................204

1.1. The period of increased timber demand (1950s - mid-1960s)...204 
1.2. Overseas timber: the extreme demand

(mid-1960s to the mid-1980s) ......................................206

1.3. Japan's forestry policy: a new approach (the mid-1980s -) ..........208

2. The trio behind the forestry policy and timber trading ..................... 212

2.1. The Forestry Agency .........................................213

2.2. Sōgo Shōsha .................................................217

2.3. The Ministry of International Trade and Industry (to 2000), and

The Ministry of Economy, Trade and Industry (from 2001) .............222

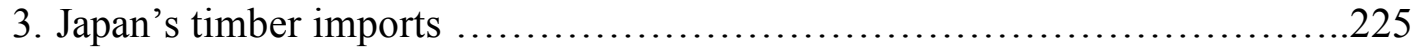

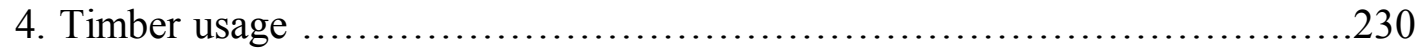

4.1. Building construction ...........................................230

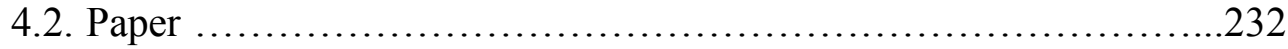

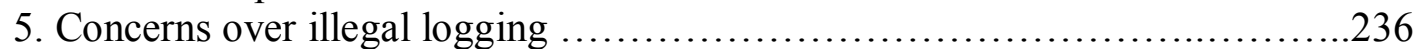

6. The ethics of the Forestry policy and of Japanese corporate practice ...........239

6.1. Ethics of the Forestry policy .....................................240

6.2. Japan's corporate ethics - a paradox .............................242

Conclusion ........................................................... 244

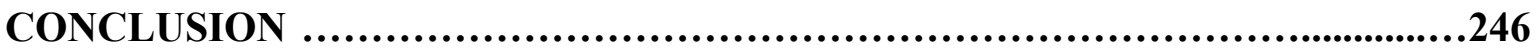

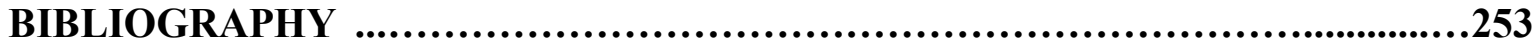




\section{LIST OF TABLES, GRAPHS, FIGURES AND A MAP}

\section{CHAPTER ONE}

Table 1 List of Environmental ethics / theories

Figure 1 Formation of the Japanese environmental ethics

\section{CHAPTER TWO}

Figure 1 The triangle of players in the Japanese domestic environmental policy ....71

\section{CHAPTER THREE}

Table 1 A compassion of $\mathrm{CO}^{2}$ emissions by sector

Figure 1 The triangle of players in the Japanese global environmental policy....

\section{CHAPTER FOUR}

Table 1 ICR income and expenditure for scientific research whaling during the

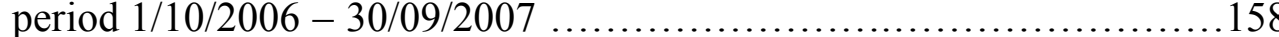

Table 2 Japan's special permit catches from 1987 to 2006 ......................159

Graph 1 Comparison of meat type consumption in Japan between 1948

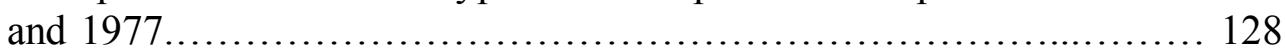

Figure $1 \quad$ List of large whales managed by the IWC ............................139

Figure 2 The Whaling Triangle and its associates

\section{CHAPTER FIVE}

Table 1 Reported nuclear related mishaps in Japan

Graph $1 \quad$ Nuclear power plants built between 1970 - 2006

Graph 2

The Japanese nuclear related budget between 1954 and 1969

Figure 1 The Japanese nuclear power triangle ............................... 180

Figure $2 \quad$ The Nuclear Inc. network ....................................... 185

Figure 3 The three pillars of ethics in the use of nuclear energy ................. 190

Map 1 Nuclear power plants built and operating in Japan between 1970 and 2006

\section{CHAPTER SIX}

Table 1 Financial results (consolidated) as at 31 March 2007 of the top six Sōgō Shōsha and their keiretsu ...............................................220

Table 2 Timber exporting countries to Japan $(1990$ 2003) .......................228

Figure 1 Japan's self-sufficiency rate for timber between 1955 and 2005 ....... 207 
Figure 2 The percentage of forestry workers aged over 65 between 1975 and 2004

Figure 3 The triangle of players in the Japan's forestry policy ...................213

Figure $4 \quad$ Volume of timber imported into Japan .................................226

Figure 5 Comparison of imported and domestic timber (log conversion) ...........227

Figure 6 Timber usage in Japan by percentage ..............................230

Figure $7 \quad$ Number of new homes built between 1980 and 2005 ..................232

Figure $8 \quad$ Changes in the price of waste paper (1972 1999) ....................235

Figure 9 Destination of Japan's waste paper exports .........................235 


\begin{abstract}
This thesis examines several Japanese government policies that impact on the environment in order to determine whether they incorporate a sufficient ethical substance. Japan built its domestic environmental policy on the experiences of combating its catastrophic post war pollution crises; these crises were created as the result of the country's relentless drive towards becoming a world economic super-power. As with many other countries, global environmental issues are an important agenda in governments' policies and from the late 1980 s the Japanese government incorporated global initiatives into its domestic environmental directives. Since that time climate change issues have become a focal point of Japan's environmental policies, and by the 1990s the country had by means of regulations moved from being one of the world's most polluted countries, to one that had become one of the world's most environmentally responsible. However, Japan's economic success from the 1980s led to mounting criticism over its overseas business practices, practices that discounted the value of the ecosystems of its trading partners.

In the enquiry into the ethics of the policies, this thesis explores how Western philosophers combined their theories to develop a 'Western environmental ethics code'; the thesis also reveals the existence of a unique 'Japanese environmental ethics code' built on Japan's cultural traditions, religious practices, and empirical experiences. The discovery of the distinctive Japanese code is not only important for what it discloses as a new philosophy, but most importantly how it can be used to analyse the ethical framework of the Japanese policies. In spite of the positive contributions that Japan has shown towards the global environment, the government has failed to show a corresponding moral obligation to the world ecology in its global environmental policy. The policies examined in the three case studies comprising whaling, nuclear energy, and forestry, have also been found wanting in ecological ethical considerations, both from a Western and Japanese perspective. The main reason for this is that the integrity of the policies has been compromised by Japanese vested interest groups; business and political interests ensure that the policies are primarily focused on maintaining sustainable economic growth. Whilst Japan's global environmental policy initiatives are the key to its economic survival into the $21^{\text {st }}$ century, and these initiatives may achieve their aim, they do however fail the Japanese code of environmental ethics.
\end{abstract}




\section{DECLARATION}

NAME: _ Midori Kagawa-Fox

PROGRAM: Doctor of Philosophy

The work contains no material which has been accepted for the award of any other degree or diploma in any university or other tertiary institution and, to the best of my knowledge and belief, contains no material previously published or written by another person, except where due reference has been made in the text of the thesis.

I give consent to this copy of my thesis, when deposited in the University Library, being made available for loan and photocopying, subject to the provisions of the Copyright Act 1968.

I also give permission for the digital version of my thesis to be made available on the web, via the University's digital research repository, the Library catalogue, the Australasian Digital Theses Program (ADTP) and also through web research engines, unless permission has been granted by the University to restrict access for a period of time.

SIGNED:

DATE:

$\underline{2009}$

\section{Supervisors:}

\section{Professor Purnendra Jain}

Discipline of Asian Studies in School of Social Sciences, the University of Adelaide

\section{Professor Timothy Doyle}

School of History and Politics, the University of Adelaide 


\section{ACKNOWLEDGMENTS}

I am extremely thankful to my supervisors, Professor Purnendra Jain and Professor Tim Doyle, whose encouragement, guidance, and support throughout my research has enabled me to develop the skill of critical thought. I greatly appreciate the tremendous patience and tolerance which they have extended to me during the past years which contributed to my being able to complete the thesis.

Professor Jain has been my principle supervisor whose scholarly challenges helped me to develop an independent, investigation ability. I was most fortunate in being able to benefit from the vast experience and knowledge that he has acquired from his Japanese studies. This forced me to be accurate and logical with my arguments and he was always available to support me; his trust in my research was a driving force behind my belief that I would be able to complete the task. I will value the years working under the supervision of a scholar and mentor.

Professor Tim Doyle has been my co-supervisor and his scholarly input, particularly in the field of environmental ethics, has been invaluable. His questioning led to me to investigate and explore a new field, that of a distinctive Japanese environmental ethics model, and for this I am extremely thankful.

I am indebted to the Centre for Asian Studies in the University of Adelaide; it has given great support by providing the facilities for me to pursue and complete my thesis. I would like to particularly thank Ms. Androniki Pavilidis and Ms. Shoo Lin Siah from the administration team who have helped me with all the paper work and were a great support. I would like to express gratitude to the lecturers in the Japanese language courses who supported me over the past years, Dr. Shoko Yoneyama, Ms. Naomi Aoki, Ms. Kayoko Enomoto, and Ms. Akiko Tomita, and the lectures of Asian Studies / Social Science courses, Dr. Sejin Pak and Dr. Gerry Groot. Their assistance to me while teaching in the courses developed my skills and showed me what scholarly writing is about. 
I owe a deep gratitude to the many people who have spent untold hours reading my papers and offering their warm support. My neighbours, Dr. Catherine Delin and her husband Dr. Peter Delin, kindly read my chapters and gave me constructive feedback. Ms. Lia Fox helped me editing my research proposal in the early stage of my candidacy; this help established my early confidence for the long journey. Mr. Brian Danilko also supported me by reading and commenting on my papers. I deeply appreciate the support of these people whose time and dedication helped ease the pain of the journey.

I give special appreciation to Dr. Vic Beasley for his professional editing; his understanding of thesis writing was indeed very helpful.

I would like to express my gratitude to Professor Shuichi Kitoh in the Institute of Environmental Studies, the University of Tokyo. Reading his books during my literature review moved me to meet and talk with him at his previous post at Keisen University, Tokyo. Professor Kitoh's passionate concern about environmental issues was a further inspiration and led me to the way of Japanese environmental ethics. I also would like to acknowledge the information and offer given to me by Dr. Mike Danaher regarding whaling matters.

I would like to express gratefulness to my fellow postgraduates. Firstly to Dr. Sofei Wong who was especially supportive and close; her encouragement and trusting friendship whilst I was working on my thesis helped me achieve that goal. Others in the postgraduate room included Ms. Heather Longford, Mr. Ming Hwa Ting, and Ms. Joy Ricci; I will miss the early mornings spent with Joy and Ming in the room that became my refuge, a place where I felt comfortable while working on my research.

This thesis would not have been possible without my husband's love, continued support, and encouragement. He put up with me over a long time and was so patient throughout the process; reading and checking my papers over and over. His dedication was not only for reading my papers but also other chores around the house which enabled me to spend more time on my chapters; without exaggeration I could not have achieved this work without his endurance. He deserves to receive a Ph.D. (Partners Honourly Degree); his commitment to help compelled me to complete this thesis for him. I am grateful for the love and devotion 
that I received from Letitia my Saluki dog, she was always waiting to greet me when I returned home, and to comfort me during difficult times.

Finally, my deep and great respect to my parents and to my sister whose encouragement and endless love has been my strength; it has enabled me to carry through with this opus. Even though my sister was not entirely sure of the nature of my thesis, she collected Japanese newspaper articles for me to use in my research. My parents are the hardest working and humblest people I know; my mother loved to study and my father wanted to play during his youth, but instead they had to put their efforts into working hard to sustain their siblings. Although they do not altogether understand my thesis, their belief in my work and their endless love and support during my study time, have been both a source of strength, and a shining example for me to follow. 


\section{Work related to this thesis}

\section{Publications (peer review):}

Kagawa-Fox, Midori, “Japan's Whaling Triangle - the power behind the whaling policy", Japanese Studies, vol. 29, no. 3, December 2009.

Kagawa-Fox, Midori, "Environmental ethics from Japanese perspectives", Ethics, Place and Environment, 2010 (Accepted for forthcoming publication).

\section{Conference presentations:}

2008 - Asia Pacific Futures Network Signature Event, the Globalizing Religions and Culture in the Asia-Pacific, at the University of Adelaide. Presented a paper on the comparative aspect of Japanese and Western environmental ethics.

2006 - Asia Pacific Week at the Australian National University. Presented a paper on Japan's global environmental policy.

2005 - The $14^{\text {th }}$ Biennial Conference of the Japanese Studies Association of Australia at the University of Adelaide. Presented a paper on the development of Japanese environmental ethics.

2003 - The $7^{\text {th }}$ Annual Humanities Graduate Research Conference at Curtain University, Western Australia. Presented a paper on Japan's nuclear power policy program. 
In this thesis, Japanese names are written in Western order, given name followed by family name. Japanese words are rendered in the style of Hepburn romanization and italicised, with macrons indicating long vowels, for example ' $\bar{o}$ ' as in Kōgai', except in cases of personal and place names, and other words easily recognized.

The thesis has used a number of Japanese books, journal and newspapers; where the sources are in Japanese the translations into English are rendered by the author. 


\section{INTRODUCTION}

\subsection{Objective of the thesis}

The objective of this thesis is to determine whether Japan's environmental policies incorporate a sufficient degree of ethical consideration. As an industrialised nation it is expected that Japan's environmental policies would contribute to the nurture of the natural world and to ensure viability of the livelihoods of indigenous peoples who are affected by resource expropriation. The Japanese government believes that it has the skills and experience to combat global environmental problems as it successfully overcame its catastrophic domestic pollution during the 1950s and 1960s. Whilst Japan's Global Environmental Policy (GEP) has shown a firm and positive commitment towards the global ecosystem, other policies that impact on the natural world outside of Japan do not appear to demonstrate a similar consideration. Many of Japan's policies are designed to prioritise the goals of Japanese vested interests at the expense of the global ecology. Three key policies will be used as case studies in order to assess their degree of ethical content; they are the whaling policy, the forestry/timber-trading policy, and the nuclear energy policy. Any policy that has a bearing on the environment needs an ethical/philosophical basis to ensure that its focus remains sound. As Robert Goodin has stated, a philosophical insight should be employed by policy makers in order that they may choose an appropriate plan to contend with the environmental problems that now confront the world. ${ }^{1}$

This thesis endeavours to reveal ethical deficiencies in the policies of the three case studies, policies that impact on the environment; in addition, the thesis will further unveil the two faces of Japan's GEP. The first face is of a policy that attempts to protect, conserve and sustainably use global resources; the second is that of a policy, under the guise of sustainable development, designed to benefit the so called 'Japanese Iron Triangles'. Sometimes known as a 'Ruling Triad', an Iron Triangle is an association of three dominant elites; government bureaucrats, big business, and politicians. When dealing with environmental issues, this arrangement ensures a comfortable accommodation of their

\footnotetext{
${ }^{1}$ R. Goodin, Utilitarianism as a public philosophy, Cambridge, Cambridge University Press, 1995, p. 308.
} 
interests in the matter of guidance, compromise, negotiation, and self-regulation. I will use the three case studies to support my argument and to appraise Japanese policies and practices in the light of sustainable and ethical environmental management.

\subsection{Background to the research}

The Japanese have two terms that refer to environmental harm, koggai (公害: public poison) and kankyō mondai (環境問: environmental problems). The terms are similar in meaning; koggai was in use until the 1980s but faded away after the introduction of the term kankyō mondai in early 1970. The change may indicate a shift of emphasis from 'public' (domestic) environmental problems to global ones. In the late eighteenth century the link between environmental pollution and harm to human health was recognized. According to Jun Ui, as the result of large scale industrial development serious kōgai were identified in the early Meiji era; ${ }^{2}$ in 1868 the new government wanted Japan to become modernized and as a consequence it emphasized industrialization. The Ashio kōzan (Ashio copper mine) became the site of Japan's first mining kōgai occurrence and is located in Tochigi prefecture in the northern portion of the Kantō region; it started operating in 1610 and continued until 1973. F.G. Notehelfer pointed out that by the 1890 s the mine was one of the world's leading copper producers ranking with Anaconda, Calument-Hecla, and Rio Tinto. ${ }^{3}$ It played an important role in the development of Japan's industrial modernization and strengthened the nation's military capabilities. In the historical record of Ashio kōzan there is a saying, "Copper is the nation" implying that without Ashio's copper the SinoJapanese (1894-1895) and the Russo-Japanese (1904-1905) wars could not have been won. ${ }^{4}$

In 1877 the government owned mine was handed over to a private company, Furukawa Co. Ltd.; the subsequent mining operations caused tremendous environmental pollution. Kenneth Pyle pointed out that the company deforested an area covering forty square miles around the mine site which led to the destruction of the watershed of the Watarase River; the resultant flooding and pollution damaged the health and destroyed the livelihood of

\footnotetext{
2 J. Ui, Kōgai genron (Kōgai Principle), Aki Shobō, 1989, p. 193.

${ }^{3}$ F. G. Notehelfer, "Between tradition and modernity. Labor and the Ashio Copper Mine", Monumenta Nipponica, vol. 39, no. 1, Spring 1984, p. 12.

${ }^{4}$ Ui, Kōgai genron (Kōgai Principle), p. 227.
} 
thousands of villagers within the adjacent Kanto Plain. ${ }^{5}$ One contributing factor to this koggai incident was the precursor to a recurring theme in the government's approach to big business, viz. a reluctance to regulate industrial pollution. Pyle mentioned that Furukawa had a cosy relationship with members of the government cabinet; ${ }^{6}$ this type of relationship was the cause of the catastrophic kōgai occurrences that happened soon after World War II (WWII).

At the end of WWII Japan's priority was to rebuild its shattered economy; as a result of its single minded determination, by the 1950 s the country had achieved that aim. The Government's 1956 Economic White Paper stated that the country was, “mohaya sengo dewa nai (no longer in the post war period)", and that from a fiscal point of view it had recovered. However, this recovery came at a huge cost to the Japanese people and to their environment. Pollution on a scale that had never been seen before ruined the health of thousands of Japanese and devastated large areas of the country. Japan's determined pursuit of industrial growth from the 1950s through to the 1970s, coupled with the unregulated activities of large chemical factories, led to four major occurrences of koggai. They were the two outbreaks of Minamata disease, Itai-itai disease, and Yokkaichi asthma. In the first three cases it affected people who used water and ate fish that had been contaminated by effluent from chemical manufacturing works; in the fourth case it affected the people who lived near a large petrochemical complex and were subjected to a polluted atmosphere. Many died and thousands were left with lifelong disabilities; tragically, the effects of these diseases were in some cases passed on to subsequent generations.

During this period of rapid industrial development, the industry's lack of moral consideration, abetted by the government's complicity in the debacle by not enforcing emission control regulations, caused the whole nation to suffer. The anger of the Japanese, brought on by their sense of betrayal by the ruling elites, led to the formation of environmental social movements. These movements pressured the central and local governments to establish an organization that would take responsibility for tackling the domestic environment problems. As a result, an Environment Agency was established in 1971 to be the principal government body to oversee these issues. In the absence of a

\footnotetext{
${ }^{5}$ K. Pyle, "Symposium: the Ashio Copper Mine pollution case: introduction: Japan faces her future", Journal of Japanese studies, vol. 1, no. 2, Spring 1975, p. 349.

${ }^{6}$ Ibid., p. 349.
} 
designated authority within the Japanese government to deal with environmental related problems, the Ministry of Welfare (MOW) had been the responsible authority. The MOW had focused mostly on the health and welfare of victims, but was not able to control koggai. Due to the environmental outcries in Japan at that time there was a need for the Agency to be established. The 1970 MOW Kögai White Paper signified a turning point; the use of the term kōgai was changed to the term kankyō (environment). The Minister for Welfare, whose responsibilities covered the koggai cases, stated in the 1970 White Paper that there were concerns not only from the domestic koggai incidents but also for the existing environment as it was threatened by Japan's rapidly developing industrial economy. ${ }^{7}$ Although the amenity of environment was emphasized in the government paper, kōgai was still a central theme. The change from kōgai to kankyō was first evidenced when responsibility was handed from the Minister for Welfare to the Director General of the Environment Agency in 1971. The Agency was to be the main body in the Japanese government's response to environmental issues and in 1972 Japan's first Environment White Paper was published. The Agency's first Director General, Buichi Ōishi, had been actively involved in kōgai cases; also, he was concerned over environmental matters and for the welfare of the Japanese people. In the 1972 White Paper he was the first Japanese government official to acknowledge that the current world-wide environmental problems were caused by technological advances and industrial growth by the developed nations. ${ }^{8}$ The backdrop to the establishment of the Agency was that the MOW was not able to handle the numerous environmental problems, including the koggai cases. ${ }^{9}$ It could be said that the establishment of the Environment Agency was also the result of pressure from the grassroots populace, a 'bottom up' movement started by the concerns from the most vulnerable members in the society.

By comparison, Japan's GEP was initiated not so much by domestic social pressures but rather by the emergence of a global environmental awareness that grew from international politics. In the 1980s the world's scientists and environmentalists expressed alarm over the global environmental crises that were affecting the global ecology, primary industry, wildlife, and the lives of millions of people. They sought a political solution to the

\footnotetext{
${ }^{7} 1970$ Kōgai White Paper, http://www.env.go.jp/policy/hakusyo/hakusyo.php3?kid=145, (accessed 18 February 2009).

${ }^{8} 1972$ Environment White Paper, http://www.env.go.jp/policy/hakusyo/hakusyo.php3?kid=147, (accessed 18 February 2009).

${ }^{9}$ H. Ishi, S. Okajima and T. Hara, Tettei tōron, Chikyū kankyō (Debate on the global environment), Fukutake Shoten, Tokyo,1992, p. 48.
} 
problems and the Japanese government responded quickly and positively. Whilst the domestic policy had been strengthened through tighter regulations and restrictions on industrial activities, the GEP direction was decided through compromise and consultation with Japanese industry. If Japan's domestic environment policy was a 'bottom up' approach, then the GEP was a 'top down' approach; the Japanese government saw global environmental issues not only from an environmental perspective but also from a politico/economic viewpoint. Problems associated with 'the environment' were no longer an obstacle to business aspirations; in fact, global protection of the natural world now presented opportunities to corporate Japan. Japan's GEP strategy in part attempted not to jeopardise Japanese business operations but instead to assist them. As Hidefumi Imura argued, Japan's GEP did not undermine the nation's economic growth but rather its economic growth was sustained by the policy. ${ }^{10}$ There was an accommodation and cooperation between the Japanese environmental policies and the nation's businesses; in order to sustain business development both entities needed to come to grips with environmental concerns rather than to ignore them.

From a political perspective the government wanted to present Japan as a 'Green', environmentally friendly country, one that was applying a resourceful approach to the global ecosystem. The 1988 Environment White Paper heralded the theme, "Sekai ni kōken suru kokka (The country that contributes to the world)". The paper stated that as a result of Japan's previous environmental problem solutions, the nation was confident that it could contribute to global environmental protection and preservation by using its economic power, technocratic capability, and past experience. ${ }^{11}$ Since then, the Environment Agency and other bureaucracies have been actively involved in international conferences such as the United Nations Conference on Environment and Development at Rio de Janeiro (known as the Earth Summit) in 1992. Furthermore, Japan hosted the United Nations sponsored Kyoto Conference on Climate Change (COP3) and placed the country in a noteworthy position on the global environmental scene. Besides attending and hosting conferences, the government has advanced its Official Development Assistance (ODA) to developing countries in the area of environmental protection and management.

\footnotetext{
${ }^{10}$ H. Imura, "Evaluating Japan's environmental policy performance”, in H. Imura and M. Schreurs (eds.), Environmental policy in Japan, Edward Elgar, Northampton MA, 2005, p. 351.

${ }^{11}$ The 1988 White Paper of the Environment Agency, http://www.env.go.jp/policy/hakusho/hakusho.php3?kid=163, (accessed 3 January 2007)
} 
The GEP has a similarity in focus to Japan's economic policy as they both equate technology with growth. The GEP values the notion of sustainable development, an aspect acknowledged by the international politico/environment fraternity. The policy would appear to place greater emphasis on development than on environmentally sustainable policies and practices. The GEP was not built upon community level environmental problems, but was built on outside factors such as politics, economics, and diplomatic perceptions. This policy is similar to many other public and private strategies in that it lacked a philosophical apparatus at the decision making level, one that would assure ecological sustainability.

\subsection{Argument}

The central issue of this thesis is to establish whether Japan's GEP and its diligence incorporate sufficient ethical components. Japan's GEP has shown a very positive commitment to combating global environmental concerns, but other Japanese policies that have a bearing on the environment, whether sponsored by government or business, have been queried with respect to their direction and to their moral consciousness.

What exactly is the GEP, how does it operate, and does it deal adequately with conservation and sustainability? Have the government and corporate Japan included in their overseas policies a moral responsibility to ensure the ecological integrity of those countries or regions from which it draws resources? I argue that even though Japan's GEP has made impressive diplomatic achievements, such as hosting the 1997 Kyoto Climate Conference, the basic philosophy of some Japanese policies that include whaling, nuclear energy, and forestry, fail the global ecology and fail to justify their practices from a moral perspective. Ethical considerations in policy making are vital, particularly when those policies impact both directly and indirectly on regions well away from Japan. It is essential that the Japanese government accepts responsibility to see that those policies work within an ethical framework.

In framing a global environmental policy, the application of ethics aims to clarify what the problems are, science helps to focus the key elements, and politics takes the lead in policy direction. If an ethical element is the key, what are the considerations that need to be 
applied? In the many fields of academic study the discipline of the philosophical relationship between human beings and the environment is a major one. Two pioneering philosophies in this field were 'Land Ethics' by Aldo Leopold in 1949, and 'Deep Ecology' by Arne Naess in 1973; they awakened a global environmental consciousness, especially in the industrialized Western nations. While Land Ethics reflects the existence of an ecological conscience, and this in turn reflects an inner conviction of individual responsibility for the health of the land, ${ }^{12}$ Deep Ecology takes a slightly different line. Joseph R. Desjardins argues that Deep Ecology takes a "rational, total-field" perspective and a more non-anthropocentric approach. ${ }^{13}$ In contrast to those philosophies, there was the mantra of 'sustainable development' promoted by the Norwegian Prime Minister Gro Harlem Brundtland, the chair at the 1988 World Commission on Environment and Development (WECD). Sustainable development has now become a cliché and is a key belief in policy strategies dealing with the global environment; Japan's government and businesses have shown a strong commitment to this principle. The WECD and Brundtland defined sustainable development as "development that meets the needs of the present without compromising the ability of future generations to meet their own needs". 14 Many scholars have attempted to describe sustainable development in the current environmental circumstance. Sharon Beder describes it thus: "the concept of sustainable development accommodates economic growth, business interests and the free market and therefore does not threaten the power structure of modern industrial societies". ${ }^{15}$

This thesis examines the various definitions of ethics employed in relation to environmental management. My understanding of an ethical practice in this context is one that allows a sustainability of routine more or less indefinitely into the future. Allan Holland, John O'Neill, and Andrew Light have pointed out that the concept of sustainability first began in the context of agriculture and ecology. ${ }^{16}$ Business ventures that impact on the environment, particularly those that are involved in resource exploitation, must ensure sustainability of practice and the integrity of the natural world from where it draws those resources.

\footnotetext{
${ }^{12} \mathrm{~S}$. Odin, "The Japanese concept of nature in relation to the environmental ethics and conservation aesthetics of Aldo Leopold", Environmental ethics, vol. 13, no. 4, Winter 1991, p. 347.

${ }^{13}$ J. R Desjardins, Environmental ethics, an introduction to environmental philosophy, $3^{\text {rd }}$ edition, Wadsworth, Thomson learning, Belmont, CA, 2001, p. 213.

${ }^{14}$ S. Beder, The nature of sustainable development, Scribe Publication Pty Ltd., Newham, 1993, p. xiii.

${ }^{15}$ Ibid., p. xii.

${ }^{16}$ A. Holland, A. Light and J. O'Neill, Environmental values, Routledge, New York, 2008, p. 183.
} 
As mentioned, my argument is that Japan's GEP fails to incorporate an ethical consideration, and as a result presents a false image to the world. The government portrays itself as one that values the principle of sustainable development and has incorporated that belief into policies that involve the natural world, the economy, fisheries, and even education. Japan also promotes its ability to combat global environmental concerns using its experience, technology, and know-how. At the same time economic development is not neglected; rather than curtailing business activities it seeks to ensure Japan's financial sustainability. Some Japanese policies fail to appreciate the necessity of protecting, conserving, and sustaining environmental integrity; an assessment of Japan's GEP reveals the manipulative and political hand of an Iron Triangle.

\subsection{Research significance}

The Japanese government developed an environmental policy as the result of pressure from people at the grass roots social level who were alarmed at the deteriorating condition of their environment. As in many other countries, domestic environmental concerns had become an issue. The trigger for the outcry in Japan was the catastrophic environmental pollution resulting from the government's determined and narrowly focused drive towards economic growth; the government initiated measures in the late 1960s through to the 1970 s to combat the problems. Buichi Ōishi provided a strong impetus in the formation of the environment policy as a result of his moral consciousness, and his awareness of the principles of Japanese environmental ethics. Ōishi's philosophy demonstrated an ability to structure the environmental policy from the point of view of the disadvantaged groups within the community. Although the policy today has proved to be far reaching, Ōishi's legacy has been weakened by the need to accommodate the interests of other ministries and agencies. Today, in spite of the positive aspects of the use of technology and of public participation in reducing waste, when it comes to enacting laws and enforcing regulations all too often the hand of Japanese business and commercial interests can be seen. Although Ōishi's philosophy is evident in the domestic environment policy, his values have not been upheld in Japanese global initiatives. The Japanese government changed its emphasis in the 1980s from domestic to global environmental initiatives. The cliché of sustainable development featured strongly in Japan's global policy as well as in the 
policies of other ministries and businesses; however, that cliché is often interpreted in the sense of economically sustainable development. This raises the question as to whether the Japanese global environmental policy is aimed at preserving the world's ecosystem, or whether it is being used to guarantee the continued existence of Japan's economic strength.

The study of Japan's environmental policies has attracted many researchers and scholars at home and abroad; in Japan the literature of the prominent scholar Jun Ui has become the backbone of the study of Japan's environmental problems. In particular, the Kögai genron (Principles of Koggai) gives detailed accounts of the history of domestic environment confrontations. Ken'ichi Miyamoto's Nihon no Kōgai (Japan's Kōgai) also examined the nature of the pollution in Japan and the government's responses; he is another of the many Japanese who has written on the subject. In the West, Miranda Schreurs's book, Environmental policy in Japan, co-edited with Hidefumi Imura, is one of the most extensively researched books in that field written in English; Imura's analysis of the policies adds greatly to the research. Jeffrey Broadbent's Environmental politics in Japan looks at the intense relationship between environmental preservation, politics, and economics; he demonstrates a sound understanding of the subject. There are many others, such as Hanns Maull and Mike Danaher whose critiques of the government's policies are important elements in the studies of Japan's environmental policies. However, there has been little examination of the ethical or moral aspect of Japanese policies that have a detrimental impact on the global environment.

The relationship between the Japanese people and their environment has been very close as their religious teachings emphasized living harmoniously with nature. Until the beginning of the twentieth century this important relationship had been maintained for cultural and for agriculture production purposes. Japan has always had difficulty producing sufficient food for its people and the rapid growth in its population from the nineteenth century made the situation more acute. With the exception of rice, Japan has a relatively small agricultural productivity and this has forced the country to import considerable amounts of food. A report from Japan's Statistics Bureau stated that the country's food selfsufficiency rate in 2007 was the lowest among the major industrialized nations (USA, UK, Canada, France, Germany, Switzerland and Japan); Japan had become the world's largest 
food importing country. ${ }^{17}$ Japan has also become one of the world's most economically powerful nations and this position has been built on the foundation of using global resources. Japan's traditional image of living close to and in harmony with nature is not reflected in its overseas practices; a rapacious appetite for natural commodities such as fish and timber have tarnished the country's reputation. The catchphrase 'sustainability' is often found in government policies to give them legitimacy, but it may well be dishonest.

A significant part of this thesis is to assess the soundness of the three government policies of Whaling, Forestry and Timber Trade, and Nuclear Energy by using environmental ethics theories, the Japanese way of environmental ethics, and other elements of the Japanese appreciation of an ethical/moral conduct in the policy making. Although the policies deal with different overseas resources, they have the common objective of exploiting them for Japan's benefit; this exploitation has a significant impact on the global environment. The cliché of sustainable development is their philosophical pillar as it is also in Japan's GEP. Many scholars, particularly Western academics and philosophers, have since the post war period initiated and developed various environmental ethical theories; they have enquired into the relationship between human beings and non-humans, and human beings and the natural environment. Pioneering philosophies that were developed from the perspective of environmental ethics were Aldo Leopold's Land Ethics, Arne Naess's Deep Ecology, and Peter Singer's Animal Liberation. Even though their theories differ, the common thread is a human centred approach; new theories have been developed that introduce a more global focus. Baird Callicott and Alistair Gunn aimed to elaborate beyond the original concept of environmental ethics. For example, Callicott's book Earth's Insights attempts to show a different cultural approach to environmental problems; he acknowledges that current problems are on a global scale and he examines various countries and regions including Japan.

This thesis explores the nature of the Japanese system of environmental ethics', a system that is quite different to the Western model. Whilst the Western model was based on philosophical theories, the Japanese one was based on the empirical values of the local communities. The approaches are also different; Western environmental ethics looks at the interaction between people and the environment (which includes animals) whilst the

\footnotetext{
${ }^{17}$ Ministry of Internal Affairs and Communication, the Statistics Bureau and the Director-General for Policy Planning, http://www.stat.go.jp/english/data/handbook/c05cont.htm\#cha5 2, accessed 14 January 2009.
} 
Japanese approach goes further. It involves not only the relationship between humans and the environment, but also the relationship between humans themselves. The 'human to human' relationship is integral to the concept of 'Japanese environmental ethics'. There has been little study of this aspect in the discipline of environmental ethics as most Japanese scholars argue mainly from the Western standpoint. For example, in his book Kankyō rinri gaku no susume (Introduction to Environmental ethics), the Japanese philosopher and academic Hisatake Katō gave his understanding of environmental ethics that has a similar view to Western theories. One scholar has however challenged the Western premise; Shūichi Kitoh's book Shizen hogo wo toinaosu (Questions on the protection of nature) asks readers about the meaning of that protection. He challenges some of the Western views of environmental ethics including Katō's view and introduces a fresh idea of the meaning of Western environmental ethics, one that is similar to the 'new environmental ethics' theories. An important part of this thesis will be to determine if there is a unique 'Japanese environmental ethics', and if there is, what are the essential elements and how does it differ from the Western model.

This thesis first examines several Japanese government policies that have a bearing on the natural world, and then assesses the criteria of morality in those policies and if they abide by Japanese Rinri (Ethics). The policies focus strongly on development and sustainability, but they would appear inadequately to consider the protection of the ecology and to consider if the policies are socially just.

\subsection{Methodology}

The methodology used in this thesis is largely a qualitative approach that involves an analysis of various features in order to demonstrate the central arguments; I have extensively used texts and references both from Japanese and English sources. Within a limited timeframe I visited Japanese government ministries to seek additional information, such as the Global Environmental Bureau in the Ministry of the Environment and the Far Seas Fisheries Division in Fisheries Agency. I interviewed officials such as Joji Morishita, who is the chief of the whaling section in the Agency as well as the Director for International Negotiations at the International Affairs Divisions of the Fisheries Agency. One difficulty I experienced was the development of a definition of Japanese 
environmental ethics. This is a relatively new subject and has been little researched by scholars; where it has it has been it is mainly from the perspective of Western environmental ethical theories. I interviewed Professor Shuichi Kitoh at Keisen Jyogakuin University in December 2003; currently he is at the University of Tokyo. One of his specialities is environmental ethics and my dialogue with him greatly helped my understanding of environmental ethics from his perspective and helped me develop my theoretical analysis.

I used a qualitative methodology in this thesis to analyse sources from both English and Japanese texts. Qualitative methodology involves an analysis of various features in order to argue my case; this is especially so in the areas of environmental ethics where the identification of the Japanese perspective led to new and original findings in this thesis. There has been very little research carried out on Japanese environmental ethics theories. A study of environmental ethics reveals that religious influences and a moral consciousness are its foundation, whether from a Japanese or Western outlook.

The core qualitative research in the thesis focuses on Japan's Whaling, Forestry, and Nuclear Energy policies. These case studies illustrate different environmental concerns; the use of whales as a resource, the over exploitation of foreign timber resources, and the dangers of using nuclear power. The development and exploitation of these resources must be seen in the global context of 'the common good'. If Japan is utilising and consuming these natural resources for its own benefit without a moral responsibility for the consequences, then it is doubtful whether these policies are constructed within an ethical framework. The Japanese critic Shun'ya Yoshimi made the observation that Japan's lavish standard of living has been at the expense of "expropriations and displacements against nature and against the third world. It is something to which we possess no legitimate right ...." ${ }^{18}$

\section{WHALING POLICY}

The methodology used in the whaling policy is an in depth analysis of sources from the fields of philosophy, political science, the ecology, legal studies, and Nihonjinron

\footnotetext{
${ }^{18}$ G. McCormack, The emptiness of Japanese affluence, Allen \& Unwin, NSW, 1996, P. 100
} 
(Japaneseness). My interview with Joji Morishita from Japan's Fisheries Agency in Tokyo in 2001 helped me to understand the Japanese government's stance on the whaling issue. In the case study of the whaling policy I used a qualitative research approach through an extensive analysis of many sources. Within ethical debates for instance, there are differing appreciations and interpretations. According to Peter Stoett, some preservationists maintain that the killing of whales is immoral regardless of the purpose, ${ }^{19}$ whereas the Japanese government takes the firm stance that whaling is a fisheries matter, not an environmental one; furthermore, it is ethical as long as it is managed in a sustainable manner.

One of Japan's most contentious programs is its whaling policy, in particular its so called 'scientific research whaling'. Most of the criticism is centred on the environmental aspect, although humanitarian concerns feature strongly. In spite of the condemnation of environmentalists, foreign governments and anti-whaling groups, the Japanese government has not given up on its scientific research agenda. There are at least four reasons for that determination. First, the Japanese government views whales as a resource to be used, rather than as a marine species to be protected. Second, it is claimed that whaling is a long held Japanese cultural tradition that should be maintained. Third, Japan claims that its research whaling is a legitimate activity under the auspices of the International Whaling Commission (IWC). Finally, the government deems that whales are a fish resource and not a unique marine species; it thus believes that they should be exploited as a part of its fisheries industry.

The main concerns of anti-whaling opponents are the welfare of the species and its protection in the oceans. When the Japanese government commenced its scientific research program whaling, the anti-whaling opponents strongly challenged the legality of it and claimed that is was 'disguised commercial whaling'. Whaling opponents, and the general public among many of the developed countries are concerned at the high number of whales that are killed; Japan's activities present a less than favourable image to the world. Is it because the Japanese have continued to hunt whales in the name of science, or is it a cultural clash between a country that has had a tradition of eating whale meat and countries that believe that the marine mammals should be protected? My argument is that

\footnotetext{
${ }^{19}$ P. Stoett, The international politics of whaling, UBC Press, Vancouver, 1997, p. 105.
} 
although both elements of the previous statement have credence, the present Japanese whaling policy is lacking in an ethical component. An ethical framework in a whaling policy could be defined as one that takes into account sustainability, sustainable development, and the marine environment. The Japanese government has declared that whaling is not an environmental issue but is a fisheries matter. Be that as it may, Japan's past history of marine resource exploitation is not good and its fisheries/whaling policy needs a moral component that includes a responsibility to future generations, an intergenerational fairness. A whaling policy that focuses on the narrow commercial value of the whale species, and uses government subsidies to sustain research whaling, can indeed be called into question from a moral perspective.

\section{NUCLEAR ENERGY POLICY}

The methodology in the second case study is also an analytical assessment of information drawn from numerous Japanese and English sources. The Japanese government's White Papers on nuclear energy are important indicators for an understanding of the government's position regarding it. A balanced assessment is not an easy task as most of the literature on the subject is in Japanese. However, Hayden Lesbirel's book, NIMBY politics in Japan, gives an insight into the political implications of nuclear power development in Japan, and Robert Goodin's philosophical assessment on nuclear power, are both important English sources. The analysis of the policy leads to a challenge of it from the ethical aspect of placing such a strong reliance on this energy source for Japan's economic wellbeing.

At the end of 2006 Japan was operating 55 light water nuclear power plants that provided about one third of the country's electricity supplies. A further two plants are being built for completion by 2011 , and construction has started on an additional eleven. Japan's nuclear power program has now become integral to its political economy and its significance in the future as a provider of basic energy will only increase. As well as the politico/economic significance, Japan's nuclear energy program is an important constituent of its energy security. Japan's energy dependence and usage has increased over the 
decades; it is now the fourth largest energy consumer in the world, after the United States, Russia and China. ${ }^{20}$

There are other reasons beside energy security that makes nuclear power attractive to Japan; firstly, power plants are environmentally friendly in that they do not emit $\mathrm{CO}_{2}$; secondly, it lessens Japan's dependence on the uncertainty of Middle East oil supplies; and thirdly, power generation using uranium is cost effective compared to crude oil and gas. However, although security and economics have largely shaped the policy, there has been insufficient importance placed on social and environmental consequences.

\section{FORESTRY POLICY AND TIMBER TRADE}

The methodology used in the forestry policy is an analytical assessment of sources both Japanese and English, ranging from political science and environmental studies to other forestry related fields. Although there are relatively few articles on forestry issues, Peter Dauvergne's book, Shadows in the Forest, focuses on the Japanese timber trade in Southeast Asian region, and Yoshiya Iwai's book, Forestry and the forest industry in Japan, provides valuable information on forestry and timber issues both within Japan and abroad. Many Japanese government sources were used to show how the policy was directed.

Japan's timber requirements in 2006 amounted to approximately 90 million metres of which about 80 percent was imported; ${ }^{21}$ its self-sufficiency rate of about 20 percent has changed very little over the preceding 5 years and Japan today imports timber from 130 of the world's 193 countries. ${ }^{22}$ Global timber trade has proved to be a major detriment to many of the world's forests and has become a matter for serious environmental concern. The United Nations Food and Agriculture Organization reported that in 2005 Japan was the world's second largest consumer of sawn timber, the third largest of paper and

\footnotetext{
${ }^{20}$ Industry and government energy delegation to Japan, Japan's energy future, dilemmas, policy targets and practicalities, industry science resources, Commonwealth of Australia, 1999, p. 11.

${ }^{21} 2006$ Forestry White Paper, Forestry Agency, http://www.maff.go.jp/i/wpaper/w rinya/h19/pdf/data41.pdf, (accessed 21 July 2008)

${ }^{22} \mathrm{M}$. Yabe, Mori no chikara, Nihon rettō wa shinrin hakubutsukan da (The power of the forests, The Japanese archipelago is a forest museum), Kōdan-sha, Tokyo, 2002, p. 183.
} 
paperboard, and the fourth largest of pulp wood for paper. ${ }^{23}$ Japan's heavy dependence on overseas timber has had ruinous effects, both economically and socially, in supplying countries. To bolster income, developing countries often clear-fell their forests and this technique creates a serious disturbance to, and degradation of, the forest ecosystem. The outcome is a loss of biodiversity and an excessive run off of ground water; the subsequent river pollution and spoilt environment means that the indigenous society as it existed can no longer be sustained. Intra-generational fairness needs to be taken into consideration. On the point of sustainability, there is a contradiction between the function of Japan's domestic forestry activities, and its overseas timber trading practices. The overseas operations discount the intergenerational fairness of the present over-use of natural timber resources; sustainability embraces continuity of supply. Whilst continuity may not necessarily guarantee growth, the amount of timber that is extracted should not jeopardise the maintenance of the ecosystem.

\subsection{Outline of the thesis}

This thesis comprises six chapters. The first chapter provides the theoretical framework of the thesis; it explores environmental ethics theories and the important study of philosophical questions on the relationships between humans, nature, and non-human animals. As the central argument questions the presence of an ethical framework, the traditional teachings of environmental ethics need to be analysed. The chapter investigates other ethical approaches to the environment, but the main inquiry is to identify whether there is a 'Japanese environmental ethics' that is comparable to the Western code of environmental ethics. In order to be able to articulate the Japanese code, several aspects will be looked at. These include what elements have influenced the Japanese appreciation of the natural environment, the Japanese empathy with animals, and the effect of religious influences. While the Western environmental ethics is a one way action from humans to non-humans, the Japanese understanding of environmental ethics is a reciprocal action between humans and animals, and between humans and the natural environment.

\footnotetext{
${ }^{23}$ Food and Agriculture Organization of the United Nations, the data is available at: http://www.fao.org/forestry/site/28679/en, (accessed 11 October 2007).
} 
The second chapter analyses Japan's domestic environment policy from the perspective of the traditional Japanese environmental awareness and appreciation. The foundation of the domestic policy was built on the experiences from the 1950s through to the early 1970s when Japan experienced the worst pollution it had ever known. Japan currently endorses the notion of 'green consciousness' and promotes itself as an 'environmentally friendly' nation and these principles have been strategic in its domestic policy.

Chapter three evaluates the progress of Japan's domestic policy into a global environmental focus. It examines the policy with the aim of discovering the philosophy behind it, and the policy focus, development, and direction. From the late 1980s the Japanese government has shown a positive commitment to global environmental concerns and hosted the 1997 United Nations Climate Conference known as the Kyoto Climate Conference. Japan's GEP lists sustainable development as a key philosophy in the policy; however, the sustainable development that the government has focused on seems to contradict the central value of the Kyoto conference. Because of the close ties between Government and the nation's business organizations, the policy places a strong emphasis on technology to remedy environmental problems. Corporate Japan has greatly influenced the development of the GEP; this has ensured that business is not restricted but has rather given it fresh opportunities.

Chapters four, five, and six comprise the case studies, the major part of this thesis. These chapters deal with three different Japanese policies and reveal that in each the government has failed to incorporate a satisfactory recognition of how they impact on the environment. These case studies attempt to identify some of the ethical concerns in Japanese government policies; they are the whaling, the nuclear energy, and the forestry policies; each policy has a different value focus. In spite of the different focus in the policies, their commonality is the theme of sustainable development. Each policy has a direct or indirect bearing on the environment and this raises disturbing questions.

Chapter four questions Japan's whaling policy and determines whether its policy is concerned with the ecological value of the whale species, and whether it has an ethical consideration towards the global ecosystem. Moving from the need to feed a starving population at the end of WWII, the policy focus changed to a greater emphasis on the commercial aspects of whaling. The IWC's moratorium on commercial whaling in 1987 
brought about the new era of Japan's contentious 'scientific research' whaling program: however, Japan's whaling policy and practices also give cause for alarm over its failure to maintain balance in the marine ecosystem.

Chapter five explores Japan's nuclear power energy policy to see if its substance reflects environmentally ethical and sound philosophies. Japan is a nuclear energy enthusiast and currently operates 55 nuclear power plants with many more planned to be built; the government justifies this use because of its lack of natural energy resources and its need for energy security. The nuclear industry's close association with heavy industry interests, and the unequal distribution of benefits, is of concern, as are the safety aspects of the operations. The danger to present generations from nuclear facilities, and to future generations from nuclear waste, are ethical social concerns that have not been given sufficient consideration.

Chapter six studies Japan's forestry and timber trade policy. Although Japan has 70 percent of its land covered by forests, it is at the same time one of the world's largest timber importing countries. The Japanese forestry policy emphasises the sustainability of its own forests while pursuing the sustainability of supplies of overseas timber. Whilst the policy promotes Japan as a 'green' conscious nation, it does not show a similar consideration for the 'greenness' of the environment of the supplying countries; the policy would also appear to lack an ethical consideration to ensure justice for the overseas forest inhabitants. The final section concludes the thesis by drawing on the three case studies, on Japan's domestic environment policy, and on its GEP to prove the argument. 


\section{CHAPTER ONE}

\section{WESTERN AND JAPANESE \\ ENVIRONMENTAL ETHICS \\ Environment, culture and morals}

In the Western industrialized countries (the United States, Australia and some European countries), environmental ethics has developed as an academic discipline examining the relationship between the environment and human beings. The application of this style of ethics was mainly influenced by Anglo-Saxon beliefs and was developed by philosophers, environmentalists and scholars. This approach is different from the one seen in Japan. In Japan, the knowledge and experience gained by communities was the basis on which scholars, who worked closely with those societies, shaped the code of environmental ethics.

This chapter concentrates on the philosophical apparatus behind environmental issues. It demonstrates the importance of insights into how the ethical disciplines of the West and Japan appear to be different; it also develops a new window on the Japanese system. There are three objectives in this chapter; the first is to show the important element of an 'ethical consideration' towards the environment, the second is to put forward the philosophical doctrine of environmental ethics, and the third is to identify the Japanese system of environmental ethics. Environmental ethics encompass many diverse theories, from the 'Land Ethics' espoused by the American ecologist Aldo Leopold, the 'Deep Ecology' by the Norwegian philosopher Arne Naess, and 'Animal Liberation' by the Australian philosopher Peter Singer. However, Japanese theory does not have such defined parameters. The American philosopher J. Baird Callicott, in his book Earth's Insights, has attempted to explain the relationship between the Japanese and environmental issues, but the structure of 'Japanese environmental ethics' remains largely unexplored. Many environmental philosophers agree that there are ethical concerns regarding environmental problems, and that during policy formulation making a philosophical contribution is as important as making a technological one. 
This chapter is divided into four sections. The first two deal with general aspects of policy instruments. The first examines the significance of a philosophical input while the second focuses on the two metaphors of environmental policy making, sustainability and sustainable development. The third section clarifies the concept of Western environmental ethics which has grown considerably and contributed to the inquiry of the relationship between the environment and ethical theory. The final section explains the Japanese approach. Whilst the Western model is built upon and determined by moral value judgements, the Japanese model is constructed from cultural influences and empirical considerations, with less emphasis on the significance of academic philosophies.

\section{Means to a policy}

There are numerous procedures that can be employed to combat global environmental degradation. One such method is through the application of a scientific approach. This approach can play a substantial role in the environmental arena as science focuses on existing problems. However, science cannot tell us what should be done, only what can be done. Joseph DesJardins has pointed out that a scientific approach has a real ethic and it could be justified in that it tries to ensure impartial, accurate and rational results, just as science demands that its practitioners seek to eliminate bias and verify results. ${ }^{1}$

A second means is a normative approach through the application of ethics. An ethical consideration clarifies a policy evaluation. All too often there is a gap between what has been done and what should be done, but ethics can focus on the future and produce reasoned goals for social improvement. ${ }^{2}$

A further course of action is through political decisions that shape policy direction. Sensible planning and management requires the recognition of biological integrity. All three are imperative elements in a global environmental policy, but the importance of ethics has not always been recognized. Environmental problems have often been dealt

\footnotetext{
${ }^{1}$ J. DesJardins, Environmental ethics, an introduction to environmental philosophy, $3^{\text {rd }}$ edition, Wadsworth, Thomson learning, Belmont, CA, 2001, p. 8.

${ }^{2}$ R. Attfield, Environmental ethics, environmental problems and the ethics of science, http://www.ccels.cf.ac.uk/literature/publications/2003/attfieldpaper.pdf, (accessed 12 March 2007).
} 
with by political and scientific approaches that omit, or avoid, the ingredient of philosophical wisdom.

The application of ethics in defining global environmental problems is not a straightforward task; ethics are simply not clear cut. Nevertheless, environmental ethics, the inquiry of ethical conduct towards nature, is becoming an important element in the identification of problems caused by destructive environmental practices and in the formulation of government policies. The Japanese environmental ethicist Sūichi Kitoh stated that environmental ethics has a role in supplying a framework to work at different levels in order to solve global environmental problems. ${ }^{3}$ It is tempting to find a solution using only science and technology but scientific endeavor alone has not yet been able to solve the problems. To deal with environmental issues it is necessary, along with science and technology, to link them with ethical or moral choices; technologies are not substitutes for ethics. ${ }^{4}$ Ethical considerations are a guide for the future, to maintain the values of a fair and sustainable society for coming generations. Value focus is an important aspect in an inquiry into environmental practices; it is crucial for values to be applied in order to ensure a continuing quality of life. Between peoples and countries there are differences of interpretation of values, but the placing of ethical values on the environment for the sake of future generations should be universally accepted.

During policy formation, many governments have chosen a utilitarian approach; however, some philosophers and scholars have questioned that approach, especially when the focus has been on environmental issues. The distinguished $20^{\text {th }}$ century philosopher, John Rawls, pointed out that utilitarianism does not take seriously the distinctive differences between people. ${ }^{5}$ Utilitarianism is a doctrine that aims to achieve the greatest good for the greatest number. It does not, however, take into account the rights and aspirations of the minority; that approach can result in environmental destruction as on its own it is defective. The philosophers Cochran and Malone stated that an environmental policy should identify the community problems at the lowest possible level, that is with the people who are most

\footnotetext{
${ }^{3}$ Sūichi Kitoh, A personal interview with the author, 12 December 2003, Japan.

${ }^{4}$ J. Bauer, The politics and ethics of global environmental leadership, 16 October 1992, available at: http://www.cceia.org.resources/articles papers reports/967.html, p. 14. (accessed 2 February 2007).

${ }^{5}$ J. Rawls, A Theory of Justice, The Belknap Press of Harvard University Press, Cambridge, 1971, p. 27.
} 
affected. $^{6}$ Both global and domestic environmental policies need to ensure that justice is taken into consideration. Justice is not achieved when nations that are cushioned by distance and wealth fail to consider the plight of disadvantaged people whose resources, and their labor which is also treated as a resource, have been exploited.

An environmental policy does not just have an effect on certain communities; it extends to the broad biosphere of society. A sustainable society operates within a framework of what human beings and nature can withstand. Stenmark has pointed out that the well-being of ecosystems should be the ultimate goal of an acceptable environmental policy. ${ }^{7}$

\section{Sustainability and sustainable development}

Moral obligations are required from three key groups in order to ensure that the environment is protected. Businesses have the responsibility through sound management practices to safeguard it, the government needs legislation to prevent its devastation, and the public needs to fully appreciate its value. Many ingredients are needed in the formulation of a sound global environmental policy, but the essential ingredient is sustainability. Another ingredient, of less direct consequence but nevertheless a significant one, is justice for the people who are disadvantaged by the exploitation of their natural resources. A case in point is the well known abuse of tropical rainforest resources by the industrialized nations in their quest for timber (see chapter 6).

The terms 'sustainability' and 'sustainable development' are often encountered in government and non-government papers dealing with environmental problems. These terms have been recognized in the 'new ethics' and many governments are using these terms as important principles in their environmental policies. In spite of their similarities, they have significant differences; they both deal with the problem of intergenerational equity, but the terms themselves have distinctive values. The latter term in particular has

\footnotetext{
${ }^{6}$ C. Cochran and E. Malone, Public policy, perspectives and choices, $3^{\text {rd }}$ edition, Lynne Rienner Publishers, Colorado, 2005, p. 464.

${ }^{7}$ M. Stenmark, Environmental ethics and policy making, Ashgate Publishing Limited, Hants, 2002, p. 24 and p. 81 .
} 
become a cliché often used in environmental policies. The following sections attempt to define these terms.

\subsection{Sustainability}

The basic meaning of 'sustainability' is the ability to continue a practice, more or less indefinitely, into the future. The concept of sustainability first began in the context of agriculture and ecology. ${ }^{8}$ The production of food through agriculture has for centuries been a basic primary industry necessary for human survival. In the instance of agriculture, sustainability is a necessary result if the practice is to operate within an ethical framework. Sustainability is the key for all primary industries from agriculture to harvesting natural resources. There is an ethical responsibility to future generations, to put this another way, policy makers must take account of intergenerational fairness. This fairness needs to be taken into account during policy making discussions. Sustainability embraces the continuity of production, and whilst it might not of necessity aim at growth, it certainly incorporates the congruent maintenance of the ecosystem. Sustainability is not necessarily a restriction on the uses of resources, but involves maintaining a balance between consumption and conservation, and it should therefore be at the heart of any environmental policy.

\subsection{Sustainable development}

Whilst the term sustainability originally referred to agricultural production, the term 'sustainable development' has come to encompass sustainable economic production. Sharon Beder argues that many ideas associated with sustainable development were articulated at the 1980 World Conservation Strategy. This strategy was conducted by the International Union for Conservation of Nature in collaboration with the UN Environmental Program and the World Wildlife Fund. ${ }^{9}$ According to Beder, the strategy argued that whilst development aimed to achieve human goals, it had to ensure that the use

\footnotetext{
${ }^{8}$ J. O’Neill, A. Holland and A. Light, Environmental values, Routledge, New York, 2008, p. 183.

${ }^{9}$ S. Beder, Environmental principles and policies, University of New South Wales Press Ltd., 2006, p. 4.
} 
of the biosphere could continue for ever. ${ }^{10}$ Eight years later the World Commission on Environment and Development (WECD) restored the concept of sustainable development in a report named 'Our Common Future'. The report is also known as the Bruntland Report, from the Chair of the Commission, the Norwegian Prime Minister Gro Harlem Brundtland. The WECD defined sustainable development as "development that meets the needs of the present without compromising the ability of future generations to meet their own needs". This concept became widely adopted among governments in their efforts to deal with global environmental problems. However, on the issue of environmental protections the document is rather weak. Beder opined that sustainable development aims at achieving economic growth by increasing economic productivity and can result in a lessening of the care of natural resources. ${ }^{11}$

Many scholars have attempted to define exactly what a 'sustainable environment' means. In his book, Environmental dilemmas, ethics and decision, Robert J. Berry defined it by saying that it was "a process of social and economic betterment that satisfies the needs and values of all interest groups, while maintaining future options and conserving natural resources and diversity." 12 By contrast, Beder defined it thus: "the concept of sustainable development accommodates economic growth, business interest and the free market and therefore does not threaten the power structure of modern industrial societies". ${ }^{13}$

The cliché 'sustainable development' has become a principal instrument in policy strategies dealing with the environment. Governments, the Japanese government in particular, and companies have applied the concept in their policies. Beder maintained that sustainable development accommodates economic growth, but that definition fails to ensure environmental sustainability. The capitalist market system is structured around growth, and that system is inescapably destructive and masterful. As a consequence, today decisions relating to the environment often equate to a cost-benefit exercise. The term development all too often refers to the extraction of natural resources where the majority of the benefits go to the developers and the well-connected, and where the lower socioeconomic groups miss out. It could be said that sustainable development is a development

\footnotetext{
${ }^{10}$ Beder, Environmental principles and policies, p. 18.

${ }^{11}$ Ibid., p. 19.

${ }^{12}$ R. J. Berry, “Appendix A: A code of environmental practice”, in R. J. Berry (ed.), Environmental dilemmas, ethics and decisions, Chapman \& Hall, London, 1993, p. 256.

${ }^{13} \mathrm{~S}$. Beder, The nature of sustainable development, Scribe Publication Pty Ltd., Newham, 1993, p. xii.
} 
that sustainably utilizes natural resources. Sustainable development for the industrialized nations is possible as they are able to sustain their lifestyles by obtaining resources from alternative areas when the present ones have been depleted. Sustainable development is not an option available to the non-industrialized or under-developed nations. A classic example is logging where foreign companies move into forest areas to exploit and denude the environment. The native inhabitants lose the means to continue their previous livelihoods as often their land is ruined by excessive runoff, and the biodiversity of the region runs the risk of becoming permanently damaged. Humans are dependent on the health of the world ecosystem, and any economy that grows by weakening that natural environment is eventually bound to crash.

Another point to be noted is that the practice of sustainable development frequently does not include the notion of fairness to both humans and non-humans. Failure to do so will inevitably affect the biodiversity of a region and consequently damage the natural environment of the region.

\section{Environmental ethics}

The discipline of environmental ethics is a unique, influential, but also a subtle philosophy. In the West's inquiry into environmental issues, this discipline has become an important consideration; because of the occidental origin of the philosophy it is essential to look at the nature of ethics. Many theories on environmental ethics were developed by philosophers, but now some of the contemporary theories appear to be shifting from the traditional Judeo-Christian notion to a more cosmopolitan approach.

\subsection{Ethics}

The word ethics, from the Greek ethos, translates as morality; the concept of morality is a set of fundamental regulations that guide actions. Nevertheless, ethics are not rules; they are living philosophical teachings, developed in societies through parents, teachers, and community members. However, in countries with a Judeo-Christian tradition, ethics are built upon Christian Ethics. Ronald Preston held that Christian ethics involved three 
sources of moral enlightenment: biblical teachings, ethical traditions, and moral reasoning. ${ }^{14}$ Cultural norms all contain ethics, but the interpretation or value of that ethical consciousness differs from culture to culture, and from religion to religion.

According to David Van de Veer and Christine Pierce, traditional moral outlooks and theories suppose that "only harm or benefit to humans is morally significant": ${ }^{15}$ this can be interpreted as meaning that human beings are located in the central position of moral decision making. However some Western philosophers taught of 'the community value' in ethical theory, similar to the Japanese value of community and society based ideas. The German philosopher, G. W. F. Hegel (1770-1831), proposed the theory that ethics involves the reconciling of individual freedom with the values of the community. ${ }^{16}$ That community based theory is similar to the Japanese understating of values (discussed later). Ethics are closely connected with values and religious beliefs. Lynn White pointed out in his well known 'Science' magazine article, The Historical Roots of our Ecological Crisis, the picture of the relationship between the environment and human beings. White, a professor of medieval history, believed that "Human ecology is deeply conditioned by beliefs about our nature and destiny - that is, by religion" 17 He maintained that although ethical beliefs differ from individual to individual, ethics and religious belief are intertwined and that Western ethics is conditioned by Judeo-Christian beliefs. White further argued that, ". . . Christianity, especially in its Western form, is the most anthropocentric religion the world has seen in its arrogant attitude to nature". ${ }^{18}$ White places a great deal of importance on verses about the creation in Genesis 1 of the Bible. However, in Genesis 2, although man's centrality is confirmed, so too is man's stewardship over and responsibility for the natural world. White has been challenged by the geographer Yi-Fu Tuan who pointed out that the northeastern Mediterranean had suffered massive environmental degradation following deforestation practices by preChristian Greeks and Romans; he also drew attention to instances of recurring episodes of

\footnotetext{
${ }^{14}$ R. H. Preston, The future of Christian ethics, SCM Press Ltd., 1987, p. 7.

${ }^{15}$ D. Van de Veer and C. Pierce, The environmental ethics and policy book, Wadsworth Publishing Company, Belmont, 1994, p. 11.

${ }^{16}$ P. Singer, "George Wilhelm Friedrich Hegel", in Honderich (ed.), The philosophers, Introduction to great Western thinkers, Oxford University Press, New York, 1999, p. 134.

${ }^{17}$ L. White, "The historical roots of our ecological crisis", Science, 155, 1967, p. 5. available at: http://aece.org/resources/spiritual/rootsofcrisis.pdf, (accessed 15 February 2008)

${ }^{18}$ Ibid., p. 6.
} 
wholesale land abuse by the ancient Chinese. ${ }^{19}$ White's view would seem to be somewhat blinkered.

\subsection{Environmental ethics - the beginnings}

The foundation of Western environmental ethics originated from the Judeo-Christian tradition where religious beliefs strongly influenced fundamental values. It is not known exactly how the concept of an environmental ethics evolved, but they were triggers to an awareness of environmental concerns. Three publications in particular influenced that development.

The first was Rachel Carson's famous book of 1962, Silent Spring. In her book Carson condemned the overuse in the United States of pesticides for agricultural pursuits. The book sounded alarms and alerted the world to the fact that pesticide overuse had resulted in devastating effects on humans, animals, and the natural world. Carson called into question the ethics of the U.S. government's policies that encouraged these practices. The second publication was an academic paper in 1968 titled Tragedy of the Commons by Garrett Hardin. It inspired an academic awareness of a philosophical analysis with respect to the environment; Hardin discussed population problems at that time. The third was Ronald Preston's Limits to growth (1972). It also awoke an environmental awareness, particularly in the Western nations. He noted that the ecological aspects of the 'Limits to growth' activated a vigorous debate on the relationship between humans and nature. ${ }^{20}$ These three treatises not only gave birth to the concept of an environmental ethics, but also ignited environmental movements in countries with a history of Judeo-Christian influence. An example is that in April 1970 twenty million American citizens, who were concerned at the condition of the environment, participated in the first 'Earth Day' celebration. They took a message to the political and opinion leadership that people cared and were prepared to take action. The Earth Day was not only important as a beginning in the development of an environmental ethics, but also as a day that signalled an awareness of environmental

\footnotetext{
${ }^{19}$ J. B. Callicott and R. Ames, "Epilogue: on the relation of idea and action", in J. B. Callicott and R. Ames (ed.), Nature in Asian traditions of thought: essays in environmental Philosophy, State University of New York Press, Albany, 1989, p. 282.

${ }^{20}$ Preston, The future of Christian ethics, p. 69.
} 
values; it was described as launching "the Environmental decade with a bang". ${ }^{21}$ The 1972 United Nations Conference on Human Environment (UNCHE) in Stockholm, Sweden, followed as environmental ethics awareness grew along with rising concerns about global environmental problems.

From that time American philosophers developed an environmental ethics, albeit from diverse perspectives, with the central part of their philosophy being an examination of how humans should interact with the environment. ${ }^{22}$ A primary feature in this study and development of environmental ethics was to ascertain the cause of, and responsibility for, environmental problems.

Early development focused mainly on the natural environment. In the early $20^{\text {th }}$ century the ethicist Aldo Leopold examined the effect of human activities on the natural environment and developed a theory known as 'Land Ethics'. A pioneer in the field, his ideas became well-known in the field of environmental philosophy. Land Ethics reflected the existence of an ecological conscience and this in turn reflected an inner conviction of individual responsibility for the health of the land. ${ }^{23}$ Leopold's opinions influenced many writers including J. Baird Callicott, a significant environmental philosopher in the United States. One of the important parts of environmental ethics at this time was that plants, as well as animals, should be included in environmental theory. In 1971 Callicott offered the world's first undergraduate course in environmental ethics.

\subsection{Environmental ethics - a basic understanding}

In the 1970s there emerged four very different theories dealing with environmental ethics; 'Shallow and Deep Ecology', 'Animal Liberation', 'Social Ecology', and 'Eco-feminism'. These theories had a significant influence on the shaping of an environmental ethics. In 1973, 'The Shallow and Deep Ecology', espoused by the Philosopher Arne Naess had an influential effect on environmentalism among Western nations. He argued that the

\footnotetext{
${ }^{21}$ G. Nelson, "Earth Day '70: What it meant", EPA History, http://www.epa.gov/history/topics/earthday/02.htm, (accessed 30 April 2007)

${ }^{22}$ C. Palmer, Environmental ethics, Contemporary Ethical Issues, ABC-CLIO, Inc., California, 1997, p. 6.

${ }^{23} \mathrm{~S}$. Odin, "The Japanese concept of nature in relation to the environmental ethics and conservation aesthetics of Aldo Leopold”, Environmental ethics, vol. 13, no. 4, Winter 1991, p. 347.
} 
Shallow Movements were primarily concerned with the philosophical questions relating to the relationship of human beings to their environment. ${ }^{24}$ It should be noted that Naess was himself an active environmentalist, a 'Green' as he said. His philosophical interpretation of environmental ethics was quite different from that of past environmental ethicists; Naess stated that the 'Green Movement' was a movement where good is done to the planet, not only for the sake of humans, but also for the sake of the planet itself. ${ }^{25}$ 'Deep Ecologists' seek to develop and articulate an alternative philosophy in order to replace the dominant worldview that has been responsible for the environmental crisis. ${ }^{26}$ "“Deep Ecology' starts from a philosophical or religious view that all living beings have value in themselves, and therefore need protection against their destruction from the actions of billions of humans". 27

At the same time, the theories of 'Animal Liberation' caught the attention of many philosophers and liberation groups. In 1973 an article titled 'Animal Liberation', written by the Australian philosopher Peter Singer, appeared in the New York Review of Books and caused a sensation among Western environmentalists. Singer discussed Black liberation and Women's liberation in his essay, but he pointed out that of the liberation movements, animal liberation would require a greater degree of altruism on the part of mankind as animals are incapable of protecting themselves. ${ }^{28}$ Very little consideration is given to animals in medical research or when their habitat is destroyed for the sake of so called 'development'.

Another feature of environmental ethics is the notion of 'Social Ecology', a concept founded by the American Murray Bookchin. During an interview with the Japan Environment Monitor, he defined 'Social Ecology' as an attempt to understand the social reasons for the ecological crisis, and also to find the root causes, both historically and currently, of the ecological problems facing us. ${ }^{29}$

\footnotetext{
${ }^{24}$ Palmer, Environmental Ethics, Contemporary Ethical Issues, p. 16.

${ }^{25}$ The Nancho Consultations, http://www.nancho.net/advisors/anaes.html, (accessed 12 May 2007)

${ }^{26}$ DesJardins, Environmental ethics, an introduction to environmental philosophy, p. 241.

${ }^{27}$ The Nancho Consultations.

${ }^{28}$ D. VanDeVeer and C. Pierce, People, Penguins and plastic trees. Basic issues in environmental ethics. Wadsworth, Belmont, Callifornia, 1986, p. 31.

${ }^{29}$ R. Evanoff, "Social Ecology: basic principles, future prospects. An interview with Murray Bookchin - part 1", Japan Environment Monitor, Issues \# 83, June 1996, p. 4.
} 
Whilst 'Social Ecology' looked at the problems in relation to the society and the environment, 'Eco-feminism' was about the relationship between women and nature, and the connection between social domination and nature. 'Eco-feminism' was a term first used by Françoise D'Eaubonne in 1971. Since then that view has been widely discussed by many philosophers, especially by the many female ecological thinkers known as 'Ecofeminists'. It could be said that it is holistic in the sense that the theory encourages humans to understand themselves as essentially a part of the human and natural communities. ${ }^{30}$ It, along with 'Social Ecology', has made a significant contribution to the development of an environmental ethics. Social Ecology and Eco-feminism take different approaches to the environmental crisis, but they seem to share similar philosophies. As Des Jardins pointed out, Social Ecologists and Eco-feminists believe that the domination and degradation of nature arise from social patterns of domination and hierarchy, patterns of social life in which some humans exercise control or domination over others. ${ }^{31}$

\subsection{The development of a 'new' environmental ethics}

In the early stages of its development, environmental ethics was very much an American model which espoused a human dominant position. A different perspective, leading to a new environmental ethics, emerged when the global environmental problems were brought to the attention of scientists, political leaders and environmentalists.

The new philosophy of environmental ethical theory started developing into a new paradigm that focused on regional and multicultural aspects, with an ethical application. The New Zealand philosopher Alastair Gunn represented that view. He argued that environmental ethics as practiced in the United States, Britain, Europe, and Australia, exhibited a rather disturbing monoculturalism. ${ }^{32}$ He stated that because traditional environmental ethics was born in the United States, it simply equated more precisely the Western, Christian view on environmental concerns. Moreover, Gunn claimed that "while all environmentalists talk of global problems, they are not always so quick to acknowledge,

\footnotetext{
${ }^{30}$ DesJardins, Environmental ethics, an introduction to environmental philosophy, p. 256.

${ }^{31}$ Ibid., p. 235.

${ }^{32}$ A. Gunn "Can environmental ethics save the world?", in F, Feríe and P, Hartel (eds.), Ethics and environmental policy, theory meets practice, The University of Georgia Press, Georgia, 1994, p.196.
} 
or even notice, the possibility of different cultural perspectives on environmental issues". ${ }^{33}$ Two Australian philosophers, Richard Routley and Val Routley, also questioned the current environmental ethics; they believed that Western ethics appeared to retain a fundamental form of chauvinism, namely human chauvinism. ${ }^{34}$ Human chauvinism judges values and morality to be ultimately concerned entirely with humans; non-human beings, as well as plants, have a lesser value but they create constraints on human action in serving human interests. ${ }^{35}$ Gunn, Callicot, and the Routleys are some of the advocates who believe that traditional environmental ethics need to be adjusted in order to meet the present day global environmental crises.

Two likely reasons that in part contributed to the rise of the new environmental ethics were the growing awareness of unfair resource transference brought about by globalization, and the consequent deprivation of the affected indigenous communities. When these events came to the attention of philosophers and scholars, they were tempted generally to apply accepted environmental ethics. Callicott challenged this and questioned the validity of the Western ethos. He believed that it was as arrogant as it was hopeless to believe that environmental ethics could be exported without due consideration to the rich intellectual traditions of non-Western cultures. ${ }^{36}$

As environmental problems grow to encompass the globe, an environmental ethics needs to progress into a global conception. The philosophers Richard Botzler and Susan Armstrong proposed a different view for a new environmental ethics. They advocated that environmental ethics should have a multicultural aspect; both the Western and nonWestern countries must address the concerns and understand them to build up successfully a respected, effective global environmental ethics. ${ }^{37}$ This multicultural aspect is shown when in 1974 the World Council of Churches, due to the experiences of third world Christians, concluded that the term "Participatory" should be added to the concept of a "Just and Sustainable" society. ${ }^{38}$

\footnotetext{
${ }^{33}$ Gunn "Can environmental ethics save the world?", p. 196.

${ }^{34}$ R. Routley and V. Routley, "Against the inevitability of human chauvinism”, in R, Elliot (ed.), Environmental ethics, Oxford University Press, New York, 1995, p. 104.

${ }^{35}$ Ibid., p. 104.

${ }^{36}$ B. Callicott, Earth's insights, a survey of ecological ethics from the Mediterranean basin to the Australian outback, University of California Press, Berkerly, Los Angeles and Calfornia, 1994, p. xiv.

${ }^{37}$ R. Botzler and S. Armstrong, Environmental ethics, Divergence and Convergence, $2^{\text {nd }}$ Edition, McGrowHill, Boston, 1998, p. 3.

${ }^{38}$ Preston, The future of Christian ethics, p. 75.
} 
In spite of the significance of the newly developed environmental ethics, it cannot be simply exported without taking into account the cultural values of the people in these recipient countries. Callicott's book Earth's Insights explains the multicultural aspects of the environmental and ecological ethics of the native people in Asia, South America, Africa, and Australia. The Australian environmental philosopher Val Plumwood refers to the Australian aboriginal culture as a model of bioregionalism in which the people have a sense of personal closeness to the land. ${ }^{39}$ Western philosophers have taken inspiration from the Eastern wisdom that humans are a part of nature and must conform to natural processes and cycles. An appropriate technology is one that utilizes natural forces as opposed to one that attempts to reorganize and dominate them. ${ }^{40}$

Practicality in environmental ethics is as important as its philosophical theories; in teaching environmental ethics, the primary focus should be on the sustainability of the environment. Environmental ethics is the application of responsibilities, rights, and democracy to environmental concerns. Sustainability is the practicality of an ethically-sound philosophy and that aspect is imperative. In 2005 over one billion people worldwide, that is one in every six, lives in conditions of 'absolute poverty'. 41 The gap between the rich and the poor countries is widening, and those people who live in absolute poverty are often the worst affected by global environmental problems. Bradley Harsch argued that the blame for the majority of the world's environmental problems should be laid at the feet of the world's rich industrialized nations. ${ }^{42}$ He stated that the "wealthy industrialized nations, though constituting only 20 percent of the world's population, account for eighty percent of the world's consumption of fossil fuel". 43

The new environmental ethics that has emerged has been articulated by philosophers and other concerned people. What is significant is that it widens the application of values and morality to deal with the current environmental crisis; it not only takes into consideration

\footnotetext{
${ }^{39}$ Callicott, Earth's insights, a survey of ecological ethics from the Mediterranean basin to the Australian outback, p. 184.

${ }^{40}$ Ibid., p. 11.

${ }^{41}$ J. Sterba, "World Justice”, Journal of Social Philosophy, vol. 36, no. 2, Summer 2005, p. 159.

${ }^{42}$ B. Harsh, "Consumerism and environmental policy: moving past consumer culture", Ecology Law Quarterly, vol. 26, no. 3, 1999, p. 548.

${ }^{43}$ Ibid., p. 548.
} 
cultural values and value differences, but also seeks methods other than ethnocentric ones in evaluating ethical principles.

Table 1 lists the various theories dealing with environmental ethics that have contributed to the notion of the new Western environmental ethics. 
Table 1: List of Environmental ethics/theories

\begin{tabular}{|c|c|c|c|}
\hline $\begin{array}{l}\text { Name of the } \\
\text { Environmental ethics/ } \\
\text { theory }\end{array}$ & Founder & Position & Concept \\
\hline Deep Ecology & Arne Naess & $\begin{array}{l}\text { Norwegian } \\
\text { philosopher }\end{array}$ & $\begin{array}{l}\text { Concerns with fundamental } \\
\text { philosophical questions about the } \\
\text { ways in which humans relate to } \\
\text { their environment }\end{array}$ \\
\hline Social Ecology & $\begin{array}{l}\text { Murray } \\
\text { Bookchin }\end{array}$ & $\begin{array}{l}\text { American } \\
\text { philosopher } \\
\text { and political } \\
\text { thinker }\end{array}$ & $\begin{array}{l}\text { The root of our ecological crisis } \\
\text { lies in certain social factors }\end{array}$ \\
\hline Eco-feminism & $\begin{array}{l}\text { Francoise } \\
\text { d'Eaubonne }\end{array}$ & $\begin{array}{l}\text { Feminist } \\
\text { philosopher }\end{array}$ & $\begin{array}{l}\text { Feminist philosophies in ecological } \\
\text { issues have tended to adopt } \\
\text { approaches based on context and } \\
\text { on relationships of care }\end{array}$ \\
\hline $\begin{array}{l}\text { Spiritual Ecology, } \\
\text { "preserving" wild } \\
\text { nature }\end{array}$ & John Muir & $\begin{array}{l}\text { American- } \\
\text { influential } \\
\text { naturalist } \\
\text { and } \\
\text { conservat- } \\
\text { ionist }\end{array}$ & $\begin{array}{l}\text { The Sierra Club, the first major } \\
\text { organization, influenced the } \\
\text { modern ecological movement. }\end{array}$ \\
\hline Land ethics & Aldo Leopold & $\begin{array}{l}\text { American } \\
\text { ecologist } \\
\text { and environ- } \\
\text { mental } \\
\text { writer }\end{array}$ & $\begin{array}{l}\text { Human activities on the natural } \\
\text { environment: 'harmony with } \\
\text { nature' }\end{array}$ \\
\hline Biocentrism & J. Baird Callicott & $\begin{array}{l}\text { American } \\
\text { environ- } \\
\text { mental } \\
\text { philosopher }\end{array}$ & Whole biotic community or system \\
\hline $\begin{array}{l}\text { Utilitarian - animal } \\
\text { liberation }\end{array}$ & Peter Singer & $\begin{array}{l}\text { Australian } \\
\text { philosopher }\end{array}$ & $\begin{array}{l}\text { Care, concern and a general raising } \\
\text { of standards in the treatment of } \\
\text { animals by human beings }\end{array}$ \\
\hline Life-centered theory & Paul W. Taylor & $\begin{array}{l}\text { American } \\
\text { philosopher }\end{array}$ & $\begin{array}{l}\text { 'Respect for nature'. People have } \\
\text { prima facie moral obligations that } \\
\text { are owed to plants and animals } \\
\text { themselves as members of the } \\
\text { Earth's biotic community }\end{array}$ \\
\hline $\begin{array}{l}\text { Human chauvinism } \\
\& \text { environmental } \\
\text { ethics }\end{array}$ & $\begin{array}{l}\text { Val and Richard } \\
\text { Routley (Currently, } \\
\text { Val Plumwood and } \\
\text { Richard Sylvan) }\end{array}$ & $\begin{array}{l}\text { Australian } \\
\text { philosophers }\end{array}$ & $\begin{array}{l}\text { Western ethics are examples of } \\
\text { human chauvinism which sees } \\
\text { value and morality as ultimately } \\
\text { concerned entirely with humans }\end{array}$ \\
\hline Intermediate level & $\begin{array}{l}\text { Richard Sylvan } \\
\text { \& David Bennet }\end{array}$ & $\begin{array}{l}\text { Australian } \\
\text { philosophers }\end{array}$ & $\begin{array}{l}\text { Rejection of the notion that } \\
\text { humans and human projects are the } \\
\text { sole items of value }\end{array}$ \\
\hline $\begin{array}{l}\text { Deontological rights } \\
\& \text { inherent value }\end{array}$ & Tom Reagan & $\begin{array}{l}\text { American } \\
\text { philosopher }\end{array}$ & $\begin{array}{l}\text { Both humans and animals have } \\
\text { rights }\end{array}$ \\
\hline $\begin{array}{l}\text { Life style change } \\
\text { dogma }\end{array}$ & Kirkpatrick Sale & Journalist & $\begin{array}{l}\text { The Western materialistic life style } \\
\text { will destroy the environment }\end{array}$ \\
\hline $\begin{array}{l}\text { The principle of } \\
\text { "Buddhist } \\
\text { economics" }\end{array}$ & $\begin{array}{l}\text { Ernst } \\
\text { Schumacher }\end{array}$ & $\begin{array}{l}\text { German/ } \\
\text { British } \\
\text { philosopher, } \\
\text { Rhodes } \\
\text { Scholar in } \\
\text { economics }\end{array}$ & $\begin{array}{l}\text { "Production from local resources } \\
\text { for local needs is the most rational } \\
\text { way of economic life" }\end{array}$ \\
\hline
\end{tabular}




\section{Japanese environmental ethics}

The subject of Western environmental ethics has been widely written about and discussed, but the same cannot be said of Japanese environmental ethics. It has not been covered in any branch of Japanese philosophy, nor has there been enough pressure from academics and environmentalists on philosophers and scholars to highlight environmental concerns and to promote public discussion. In spite of the scarcity of documentation regarding Japanese environmental ethics, it can be argued by reference to scattered evidence that it differs from the Western model in that it is based on cultural and empirical values.

This section analyzes the formation of the Japanese environmental ethics. In order to be able to articulate a theory of the Japanese model, an understanding of the dimensions of Rinri (Ethics), Nihonjinron (Japanese characteristics), religion, and the teachings of Japanese thinkers and philosophers, is important. These four influences combine to develop the principle of Minamata-gaku (Minamata Studies). This chapter defines Minamta-gaku as the Japanese environmental ethics. Its formation can be seen in figure 1.

Figure 1: Formation of the Japanese environmental ethics

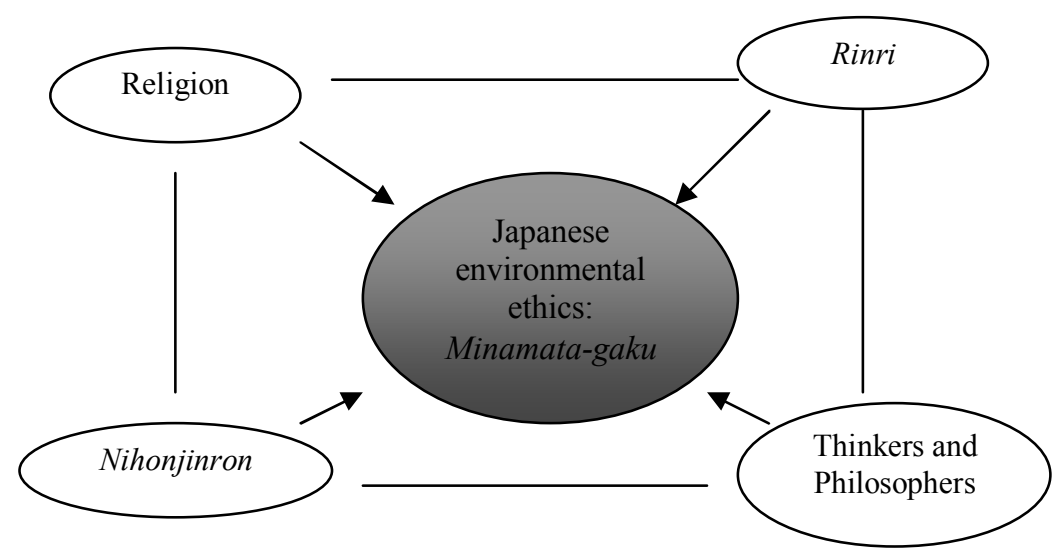

Source: Compiled by the author 
Japanese environmental ethics have not developed as an academic discipline as in the West, but through the ideas and principles built up from the community level. It is distinctly Japanese, and exemplifies one of the many forms of environmental moral consciousness found around the world.

\subsection{Japanese Rinri and Nihonjinron}

\subsubsection{Rinri (倫理: ehtics)}

The word used in Japanese to refer to ethics is Rinri (倫理) which translates as 'the maintenance of a healthy relationship with others in the community'. This significant and distinctive aspect of the Japanese interpretation of ethics can be traced back to Japan's very early history. Prince Shōtoku (Shōtoku Taishi 574-621) taught on the significance of human relationships. Hajime Nakamura has pointed out that Shōtoku emphasized two aspects in human relationships, that of harmony (和) and that of concord (協調). ${ }^{44}$ The prominent Japanese philosopher, Tetsurō Watsuji (1889-1960), stated that rinri was the way in which people of different ranks, i.e., men and women, adults and children, etc., dealt with each other. ${ }^{45}$ As mentioned, Judeo-Christian ethics has two elements: it is influenced by religious teachings and legal justification. While the Western notion has a clear consciousness of moral judgment, Watsuji declared that rinri was a pattern for appropriate and effective social interaction. ${ }^{46}$ This difference contributes in part to the recognition of a distinctive Japaneseness (Nihonjinron).

In a discussion about ethics, the English terms ethics and morality are used; in Japanese, the terms rinri and dotoku (道徳) are used. Whilst rinri deals with human relationships, dōtoku is based on Confucian thought (discussed later).

\footnotetext{
${ }^{44}$ H. Nakamura, "Basic features of the legal, political, and economic thought of Japan", in C. Moore (ed.), The Japanese mind, essential of Japanese philosophy and culture, University of Hawaii Press, Honolulu, 1967, p. 145.

${ }^{45}$ Tetsurō Watsuji, http://plato.stanford.edu/entries/watsuji-tetsuro/, (accessed 11 May 2007).

${ }^{46}$ Ibid.
} 
Watsuji's view of rinri is that Japanese ethics is demonstrated in a self-restraining manner. Because of the value of human relationships, 'respect, courtesy, and modesty' were typical examples of Japanese ethical behavior. However, that concept is now changing. In May 2006 , in a survey conducted in Japan on the subject of Japanese dignity and ethical perceptions, the majority of respondents felt that emblematic nihinjinron was disappearing. According to the survey, whilst modesty and politeness ranked as the top two terms when describing nihonjinron, it was admitted that these two attributes were disappearing. ${ }^{47}$ The survey also showed that individualism is not a trait that the Japanese desire to follow and ranked as the one they would least like to see introduced into their society. ${ }^{48}$

There is a similarity with rinri and Judeo-Christian ethics in that they were both influenced by religion and a legal system. Frank Upham stated that the Japanese legal system functions on the basis of harmony, consensus, and compromise rather than on rights and duties. $^{49}$ However, Upham can be challenged. Unlike Kant's categorical imperative theory, the Japanese legal system is influenced by the Japanese moral premise of relative retributive punishment. This premise runs counter to Bentham's ethical theory that emphasizes future circumstances, rather than what has happened in the past.

Rinri relates to the value of human relationships and it has had a great influence on judgments within the Japanese legal system. In regard to Japan's death penalty, the Justice Minister Kunio Hatoyama said in an interview in late 2007 that "(a)s the Japanese place so much importance on the value of life, it is thought that one should pay with one's own life for taking the life of another". 50

To summarize, Japanese rinri does not rely on religious teachings in temples and shrines, but through the empirical value of life in the society, whereas the Western ethical discipline is largely built on the Judeo-Christian religious system.

\footnotetext{
${ }^{47}$ Nihonjin no hinkaku, dōtoku kan ni kansuru chōsa kekka (Research on Japanese dignity and ethical perceptions), http://research.goo.ne.jp/Result/000296, (accessed 16 May 2007)

${ }^{48}$ Ibid.

${ }^{49}$ F. Upham, Law and social change in postwar Japan, Harvard University Press, Cambridge, 1987, p. 209.

${ }^{50}$ D. McNeill, "Justice Minister talks in death-penalty riddles", Japan Times, 27 January 2008, http://search.japantimes.co.jp/cgi-bin/fl20080127x3.html, (accessed 21 February 2008)
} 


\subsubsection{Nihonjinron (Japanese characteristics)}

Nihonjinron is the study of Japanese characteristics. These include identity, ideology, cultural behavior, as well as other factors that contribute to 'Japaneseness'. The prominent nihonjinron scholar Harumi Befu pointed out that nihonjinron in recent times is, by and large, built on comparing and contrasting Japan with the West, particularly with the United States. $^{51}$ The Japanese are continually shaping their national identity, an identity that attempts to maintain cultural values and to allow nihonjinron to continue. Befu believes that there is a strong relationship between the Japanese and their environment, and that this empathy with nature forms a significant part of Japanese cultural values. ${ }^{52}$ Richard Evanoff, a foreign journalist residing in Japan, pointed out that Western society emphasizes 'rights', 'democracy', and the 'domination' of nature, whilst the Japanese society emphasizes 'obligations', 'cooperation', and 'harmony' towards, or with nature. ${ }^{53}$ A survey conducted in 2003 by the Japanese Ministry of Environment, showed that public awareness of environmental problems was very high. It revealed that more than 80 percent of Japanese were concerned about global environmental problems, an increase from 75 percent in the previous year, and up from 64 percent in $1997 .^{54}$ Another survey showed that around 95 percent of Japanese strongly believe that countries need to cooperate in tackling these crises, and that they fully recognize the importance of environmental issues. $^{55}$

Nihonjinron is often seen as an enigma but, in spite of its intangible nature, many indigenous and non-Japanese scholars have over recent decades written on the subject. However, the objectivity of those theories was mainly built on the background of an emerging Japanese economy in the mid-20 $0^{\text {th }}$ century. According to a 1978 survey conducted by the Nomura Research Institute in Japan, 698 books on nihonjinron were

\footnotetext{
${ }^{51} \mathrm{H}$. Befu, Hegemony of homogeneity, an anthropological analysis of Nihonjinron, Trans Pacific Press, Melbourne, 2001, p. 6.

${ }^{52} \mathrm{H}$. Befu, Ideorogì to shiteno nihon bunkaron (The theory of Japanese culture as an ideology), Shisō no kagakusha, Tokyo, 1987, p. 43-44.

${ }_{53}$ R. Evanoff, "Beyond 'cultural differences"”, Japan Environment Monitor, vol. 7, no.2 (\#64), June 1994, p. 3.

${ }^{54}$ The Ministry of Environment, 2002, http://www.env.go.jp/policy/kihon keikaku/plan/tenken 02/koku pdf/03-2.pdf, (accessed 10 May 2007) ${ }^{55}$ The Ministry of Environment, 2002, http://www.env.go.jp/policy/kihon keikaku/lifestyle/h1610 01/03 3.pdf, (accessed10 May 2007)
} 
published between 1946 and 1978, about 60 percent of them being published after $1970 .^{56}$ As the society has changed so has nihonjinron; its importance has also waxed and waned. At times of success, such as the period before World War II, nihonjinron was seen as something of which to be very proud; however at the conclusion of the war the reverse was the case. Befu stated that from the late 1960s the Japanese again began to see themselves in a positive light and that nihonjinron portrayed their country more favorably. ${ }^{57}$ Most Japanese people today consider that they have distinctive characteristics that are unique, regardless of what they believe contributes to that distinctiveness.

\subsection{Japanese thinkers}

In this discourse a distinction needs to be made between philosophers and thinkers. Japan has had many philosophers such as Watsuji (mentioned earlier) who examined the Japanese perception of ethics. However, there were many Japanese thinkers who contributed to the evolution of the Japanese moral consciousness, although they left very few written philosophical works. Their teachings of moral principles were embedded in the value of human relationships, and it is informative to look at the diverse backgrounds of those thinkers. Shōsan Suzuki (1579-1655) taught the first occupational ethics in Japan in $1649 .{ }^{58}$ He was followed by Baigan Ishida (1685-1744), a thinker as well as a moral philosopher who taught an ethical theory of merchant responsibility during the Edo period (1603-1868). Others like Eiichi Shibusawa (discussed later), should be considered as thinkers rather than as philosophers as their practical moral principles evolved through their empirical experiences. Sontoku Ninomiya and Kenji Miyazawa were thinkers during the $19^{\text {th }}$ to the early $20^{\text {th }}$ century whose works still influence Japanese moral consciousness. What distinguishes these two thinkers is that they were not only concerned for the welfare of people, in this case farmers, but also that they instructed them on how to better themselves. Apart from Watsuji, many of the Japanese thinkers are little known outside of Japan. However, the outstanding teachings of Ninomiya and Miyazawa on the value of a moral consciousness has embedded itself in the evolution of Japanese farming. These two

\footnotetext{
${ }^{56}$ Nihonjinron, http://ja.wikipedia.org/wiki/\%E6\%97\%A5\%E6\%9C\%AC\%E4\%BA $\%$ BA $\%$ E8\%AB $\% 96$, (accessed 23 May 2007)

${ }^{57}$ Befu, Hegemony of homogeneity, p. 139.

${ }^{58}$ M. Kamiya, "Nihonjin ga motte ita shokugyō tetsugaku (Occupational philosophy that Japanese have)", Ningen kaigi, Winter 2003, p. 36.
} 
were concerned about sustainability in Japanese farming: as mentioned earlier the concept of sustainability began with agriculture.

Sontoku Ninomiya (1787-1856) was born to a farmer in Kayama village (now in Kanagawa prefecture) in the feudal system during the Edo period. He was a local leader and devoted his life to the welfare of farmers. ${ }^{59}$ Ninomiya did not write out his philosophical teachings but put forward his ethical principles in order to help farmers who at that time were suffering grievously. He said, "work hard at your occupation according to the will of your self-interest, and think sincerely about your duty to secure society regulating it" ${ }^{60}$ This can be explained as work centered on individuals, and work that served the community as a whole; together they form a state of harmony. Eiji Takemura pointed out that Ninomiya was the founder of the movement for agricultural rehabilitation known as the Hōtoku movement, a movement that spread in the Kantō region during the first half of $19^{\text {th }}$ century. ${ }^{61}$ Kantō is in the region of Tokyo and its surrounding 7 prefectures. With regards to Japanese environmental ethics, Ninomiya's work recognized the value of the environment and agriculture. He claimed agricultural production was an achievement through which 'virtuous interactions' between heaven, earth, and human beings were executed. ${ }^{62}$ Ninomiya's emphasis on the human interaction in agricultural pursuits shows his grass roots appreciation of environmental values. He taught that humans were not to dominate nature, but that they were to be a part of nature.

Kenji Miyazawa (1896-1933) is another important Japanese figure and was born in Hanamaki City, Iwate prefecture. He is known as a poet, writer, farmer, teacher and agricultural leader, but his dedication to support the disadvantaged farming communities was his outstanding attribute. Miyazawa's father was a pawnbroker so that he had first hand experience of how many farmers struggled to survive. His compassion and his love towards nature can be found in his famous poem, Amenimo makezu (Undefeated by the rain). It begins;

\footnotetext{
${ }^{59}$ Y. Shitahodo, "The Japanese tradition of economic ethics", T. Dunfee and Y. Nagayasu (eds.), Business ethics: Japan and the global economy, Issues in business ethics, Kluwer Academic Publishers, Dordrecht, 1993, p. 222.

${ }^{60}$ Ibid., p. 222.

${ }^{61}$ E. Takemura, The perception of work in Tokugawa Japan, University Press of America, Maryland, 1997, p. 110.

${ }^{62}$ Ibid., pp. $132-133$.
} 
Undefeated by the rain, the snow, or by the summer heat. A healthy body without greed, never angry but always smiling quietly Cry during the drought season, walk bewildered when the summer is cold.

This poem illustrates Miyazawa's humble attitude towards nature, and his belief that people should assimilate with it, and not fight against it, but be a part of it; this attitude captures the essence of Japanese environmental ethics.

\subsection{The effect of religion on the Japanese environmental consciousness}

Religious thought has shaped Japanese identification towards the environment, but what is interesting is that although these beliefs have influenced and formed unique social values, they have not in themselves made the society very religious. Religious beliefs are, however, an important element in shaping ethical or philosophical principles. According to the professor of Buddhist philosophy, Shōsen Miyamoto, prior to the introduction of Buddhism into Japan in the sixth century no such philosophical thought existed there. ${ }^{63}$ A comparison of the religious awareness of people in Christian countries and in Japan shows that the Japanese are somewhat indifferent to religion. ${ }^{64}$ Unlike European Christians, the Japanese have multiple beliefs that show a cultural flexibility towards religious thought; for instance, the Japanese god is not just a single deity. Many gods exist in Japanese belief. There is a saying 'Yaorozu no kamiagai (八百万の神々: eight million gods)' which implies that there are many gods who give different favors and graces in response to human wishes. ${ }^{65}$ The fact that many Japanese believe in more than one spiritual god is an illustration of another aspect of nihonjinron. Watsuji stated that unlike many other countries Japan has not experienced religious wars and its people are, by and large, tolerant towards other religions. ${ }^{66}$ There are three traditional sets of spiritual beliefs

\footnotetext{
${ }^{63}$ S. Miyamoto, "The relation of philosophical theory to practical affairs in Japan", in C. Moore (ed.), The Japanese mind, essential of Japanese philosophy and culture, p. 4.

${ }^{64}$ T. Watsuji and T. Furukawa (eds.), Nihon no bunka (Japan's culture), Mainichi Shimbun-sha, Tokyo, 1977, p. 84.

${ }^{65}$ H. Iwai, Nihon no kamigami to hotoke (Japan's Gods and Buddha), Seishun Shuppan Sha, Tokyo, 2002, p. 14.

${ }^{66}$ T. Watsuji, Watsuji Tetsurō Zenshū (Collected works of Watsuji Tesurō), no.11, Iwanami Shoten, Tokyo, 1979, p. 385
} 
in Japan, Shinto, Buddhism, and Confucianism. Although today many Japanese do not actively practice a particular religion, the beliefs of Shinto and Buddhism are still rooted in their daily lives, and Confucianism continues to survive in the constantly changing Japanese society.

Shinto is an indigenous set of beliefs that evolved from Animism and is practiced only in Japan. Built on the myths and history of Japan, it has become closely intertwined with the emperor system and encompasses the nationalistic aspect of nihonjinron. The literal meaning of Shinto is, 'the road of God (Kami)': it teaches the existence of myriad deities that have different functions and exist silently among the society. They exist for instance in the mountains, the sea, the sky, and in cosmologically related divine beings. A good example is the famous Fushimi Inari Jinjya (Fushimi Inari Shrine) in Kyoto, Japan. The name, Inari (also known as Oinari san) is known as the god relating to rice plantings; there are statues of two foxes near the Torii (Sacred Arch) and they symbolize servants of the god of rice paddies. ${ }^{67}$ Hiromi Iwai pointed out that the Fushimi Inari Jinjya is in fact a temple; the official name is Enfukuzan Myōgon ji (Enfukuzan Myōgon Temple). ${ }^{68}$ It is an illustration of the Japanese flexibility towards religion, nature's gifts, and to animals that bring benefit to the humans.

A feature of Shinto is that there is no written dogma such as in the Bible or the Koran; Japanese gods are born from feelings of threats from natural phenomena. ${ }^{69}$ The respect for nature, the admiration for nature, and being in harmony with nature, comes from Shinto teachings and has influenced the uniqueness of Japanese aesthetics. During the Meiji restoration in the late $1890 \mathrm{~s}$, Shinto flourished and emphasized nationalistic sentiments.

When Buddhism was introduced into Japan in the $6^{\text {th }}$ century, there was a confrontation with Shinto because of the differences in the two sets of teachings and beliefs. ${ }^{70}$ However, what distinguishes Japanese society is that the followers of Buddhism and Shintoism tied a knot of compatibility and co-existed; it is called Shinbutsu Shügo and means to unite two different religious teachings. ${ }^{71}$ Flexibility and patience are characteristics that can be

\footnotetext{
${ }^{67}$ Iwai, Nihon no kamigami to hotoke (Japan's Gods and Buddha), p. 50.

${ }^{68}$ Ibid., p. 50.

${ }^{69}$ Ibid., p. 27.

70 Ibid., p. 31.

${ }^{71}$ Ibid., p. 33.
} 
found in Japanese Buddhism. A further characteristic is the belief of the mutual interdependence of all elements in the universe. ${ }^{72}$ John Clammer pointed out that Japanese Buddhism has influenced, and been influenced by, a cosmocentric aspect and that the teaching is deeply rooted in the society. ${ }^{73}$

Brought into Japan in the early $6^{\text {th }}$ Century, Confucianism has not been practiced as a religious teaching but it is deeply embedded in Japanese moral philosophy. Befu pointed out that Confucian ethics strengthened the concept of belonging to a family. ${ }^{74}$ An essential value of Confucian teaching, the respect for one's parents, came to be a part of the Japanese value system. According to Watsuji, Confucianism continued to exist as 'Kokumin Dōtoku (National ethics)' in the post-Meiji period. ${ }^{75}$ This Japanese-Confucian value system could be said to have evolved as dotoku, the Japanese for morality or ethics. Dōtoku is seen in Japan as a set of moral principles and is based on Confucian thought. It became the backbone of Japanese ethics and in spite of foreign cultural values that have been brought into the country, the spirit of dotoku remains. Japanese Confucian values were elaborated on, and flourished through the writings of many influential Japanese thinkers in the early development of modern Japan. Eiichi Shibusawa (1840-1931), an early entrepreneur, is an important figure in Japanese history who contributed to the development of nihonjinron. He dealt with issues of business and morality from a Confucian perspective: he strongly believed in the principle that 'public good and selfinterest are one'. ${ }^{76}$ An appealing characteristic of Shibusawa is that he was not only a successful entrepreneur but that he also valued the importance of Confucian ethics. His principles influenced the Japanese business code that profits should be returned for the benefit of the public. There were many prominent thinkers, such as Shōzō Suzuki (15791655), and Sontoku Ninomiya (1787-1856), who inspired and influenced Shibusawa.

It has to be said that adopting and adapting to many differing religious beliefs can lead to a dilution of basic principles; the consequence of this can result in a belief that does not carry obligations.

\footnotetext{
72 J. Clammer, Japan and its others, globalization, difference and the critique of modernity, Trans Pacific Press, Melbourne, 2001, p. 60.

${ }^{73}$ Ibid., p. 60.

${ }^{74}$ Befu, Hegemony of homogenity, p. 28.

${ }^{75}$ Watsuji, Watsuji Tetsurō Zenshū (Collected works of Watsuji Tesurō), p. 350.

${ }^{76}$ K. Koga, "Keizai to dōtoku - kigyōka tachi no shisō (Business and Morality - entrepreneur's thoughts)", Ningen kaigi (Humanity Conference), Winter 2003, p. 24.
} 
4.4. The Japanese and animals.

Japanese religious beliefs have influenced the social values and attitudes of the Japanese towards the natural environment and that includes animals. The basis for the relationship with animals is built on the Buddhist belief in re-incarnation; characteristics of this relationship are reciprocal care, respect, and compassion.

These characteristics can be seen in the Japanese approach to whales and whaling. Although Japan's whaling today is restricted to the contentious scientific research expeditions, the Japanese whaler's feelings and respect towards the whales has received little acknowledgement abroad; even today in some regions of Japan this esteem remains. Although the Japanese consumed whale meat, the killing of whales was not easily accepted in the early stages of whaling in Japan and there could be two reasons for this. Firstly, whales were not regarded as fish. In 1760 the Japanese acknowledged that whales were mammals and since then their fishermen have considered whales to be special animals, different from the fish species. ${ }^{77}$ Secondly, there is a religious significance to them when they are considered as animals. Takeshi Hara pointed out that the Japanese were reluctant to kill whales as it ran counter to their traditional Buddhist beliefs although whales offered a means of survival. ${ }^{78}$ This special sentiment and respect towards whales is shown by the whaler's religious devotion to them. According to Hara, in a mark of respect to the deceased whales there were many kujira kuyō hi (religious statues for whales) erected during the Edo period (1603-1867) in shrines and temples in Japanese whaling regions. ${ }^{79}$ As mentioned earlier, the Japanese venerate whales and this can be seen in their religious services that acknowledge gratitude towards them as a resource. Although there has not been a comprehensive record made of all kujira kuyo hi in Japan, in 1990 at least fifty had been identified. ${ }^{80}$

\footnotetext{
${ }^{77}$ T. Hara, Za Kujira (The whales), Bunshin do, Tokyo, 1993, pp. 222 - 223.

${ }^{78}$ Ibid., p. 224.

${ }^{79}$ Ibid., p. 224.

${ }^{80}$ K. Nasu, Hogei seisuiki (The story of whaling's rise and fall), Kourin, Tokyo, 1990, p. 172.
} 
Another example of the Japanese attitude towards animals is shown with wolves. Brett Walker pointed out the contrast of the mindset between the Western and Japanese; in the West during the $19^{\text {th }}$ and $20^{\text {th }}$ centuries they were so detested that they were exterminated almost to the point of extinction, whereas in Japan the farmers worshiped them as sacred animals and offered up ceremonial dishes of red beans and rice. ${ }^{81}$ The spiritual significance of wolves is quite different between the Christian and Japanese religious beliefs. Walker stated that in the bible the wolf is symbolic of the wilderness and is considered a devilish animal which exists in a "place without God", whilst in Japanese religious thought wolves are seen as animals that protect grain farmers from numerous hardships. ${ }^{82}$ The Japanese have a greater empathy with animals, be they domesticated or in the wild, which indicates a two way relationship between animal and human; in contrast, Westerners have a mostly one way relationship, from humans to non-humans.

Japanese interactions with animals can be seen in the Japanese folklore where gods often accompany animals. John Knight pointed out that in Japanese myths animals are often portrayed as being appreciative of and dutiful to human kindness and compassion, and that they have shown a reciprocal intent. ${ }^{83}$ Japanese fables that feature animals contain a religious importance along with the cultural significance of the relationship with animals through the natural environment. There is a much loved story written in1949 titled, 'Tsuru no on gaeshi' (The crane repays kindness) the Japanese term on means gratitude, kindness, obligation. The story is that one day an elderly couple freed a crane that had been caught in a trap. A few days later the crane returned to the couple as a young lady in order to repay the 'on'. The interesting feature of the crane-human relationship is that it demonstrates the principle of Japanese rinri - the relationship between humans and humans, and between humans and non-humans; rinri is a recurring theme in Japanese folklore. The consequence of on is extremely important in Japanese society even today. If on has been given, then it must be returned, otherwise the recipient will be called on shirazu, meaning impolite or ill-mannered. This on relationship is based on Japanese ethics; there is an interaction through animals for harmony and gratitude to the environment.

\footnotetext{
${ }^{81}$ B. Walker, The lost wolves of Japan, University of Washington Press, Seattle, 2006, p. 7.

82 Ibid., p. 9.

83 J. Knight, "Feeding Mr. Monkey: cross-species food 'exchange' in Japanese monkey parks", in J. Knight (ed.), Animals in person, Berg, New York, 2005, p. 234.
} 
Togetherness is the key in shaping environmental ethics in Japan, whereas in the West there is a clear division between humans and non-humans. Moreover, while in the West environmental ethics is one way approach, in Japan it is two way involving gratitude and care.

\subsection{Minamata-gaku}

Even in Japan, little is known about Minamata-gaku (Minamata Studies); it is a newly developed academic subject relating to the environment. It was pioneered by the medical doctor Masazumi Harada after he had closely examined the effects of Minamata disease on his patients from the early stages of its discovery in the late $1950 \mathrm{~s}$. The disease is a neurological disorder caused by mercury poisoning. Harada has lectured on Minamatagaku at Kumamoto Gakuen University from 2002, and in 2005 the university strengthened its role in that field by officially establishing an Open Center for Minamata-gaku. Harada has been joined by other prominent Japanese scholars, all of whom have been significant in shaping Japanese environmental ethics; Shūichi Kitoh specializing in environmental ethics, Tokuji Maruyama in the Satoyama (Copse) theory, and Jun Ui in the principles of Kogai (environmental pollution).

Harada, the founder of Minamata-gaku, stated that there is no single definition of what the studies pursue. However, it is apparent that Minamata-gaku is a multidisciplinary study for the support of the disadvantaged; it also emphasizes the value of life. ${ }^{84}$ Minamata-gaku follows the Japanese way of environmental ethics. Although the approach to environmental concerns is different from the Western approach, both share a primary passion to address both domestic and global environmental concerns.

The essence of Japanese environmental ethics is contained in Minamata-gaku, whereas influences on Western environmental ethics can be traced back to the book Silent Spring. In spite of receiving very little attention from environmental philosophers, a reading of Carson's empirical work reveals a similar ideology to Minamata-gaku. Minamata-gaku pursues and determines the moral responsibilities of business, bureaucrats, and the social

\footnotetext{
${ }^{84}$ M. Harada, Inochi no tabi-Minamata-gaku he no kiseki (The path of life, traced through MinamataStudies), Tokyo Shimbun Shuppan kyoku, Tokyo, 2002, p. 16.
} 
system. These entities had previously allowed the degradation of the environment, the health of the Japanese people, and the country's social structure. Minamata-gaku does not examine environmental problems through the lens of a philosophical or ethical perspective, but is an endeavor to influence Japanese policy-makers through empirical knowledge.

An analysis of Minamata-gaku can be made through three of its characteristics.

Firstly, Minamata-gaku inquires into the responsibilities of business practices and government policy makers in order to seek the cause and the effects of environmental damage. Minamata disease became the foundation of Minamata-gaku. The unethical negligence of the regional and central governments, during and after the crisis, placed them in the position of culpability. Harada stated that the Minamata disease was not only just an illness; it was also the crime of murder. ${ }^{85}$ There is no question that irresponsible business practices and negligent supervision of regulations by government bodies were responsible for the victims' sufferings. The chemical manufacturer Chisso Fertiliser allowed methyl mercury in industrial waste water to be released into Minamata Bay and into the Shiranui Sea. It affected thousands of people in local communities and often resulted in paralysis and death; animals were also affected. The Minamata catastrophe is a graphic example of how bad business practices and weak regulators can not only harm human health, but can also destroy livelihoods. The build up of mercury in seafood not only poisoned those who ate it, but also ruined the marine environment and the fishing industry. The business executives who continued with the unsound manufacturing practices, and the government bureaucrats who knowingly did not protect the interests of their communities, failed in their moral obligations. As a consequence they must bear the direct and ethical responsibility for the disaster.

Secondly, Minamata-gaku strongly supports disadvantaged groups such as the victims of environmental disasters. After the outbreak of Minamata disease, some children who were born with its symptoms were simply diagnosed as suffering from cerebral palsy. But when Harada examined the children, he diagnosed them as victims of methyl mercury poison. He subsequently criticized the government authority that had neglected these children by

\footnotetext{
${ }^{85}$ Kumamoto Gakuen University News letter, Minamata-gaku to wa nanika (What is Minamata-gaku?), 2001, http://www3.kumagaku.ac.jp/minamata/link/gaiyo/gaiyo-01.htm, (accessed 28 May 2007).
} 
not undertaking sufficient investigation. ${ }^{86}$ A later consequence of the damage to the victim's health was their disadvantaged position in gaining and maintaining a livelihood. Val Plumwood, the Australian eco-feminist philosopher, pointed out that the poor who suffer the main consequences of environmental destruction have virtually no voice in the process that caused it or in actions taken to remedy it, unlike those decision makers who are cushioned by remoteness and privilege. ${ }^{87}$ One aspect of the catastrophe that is often missed is that the disadvantaged groups were left out of any discussions on the matter. Harada gives the example of youths who left Minamata city 30-40 years ago, have started to return to their community and are suffering from physical and psychological problems; ${ }^{88}$ these people are often overlooked or ignored by government authorities. Scholars who specialize in Minamata disease, and medical specialists, firmly support disadvantaged groups who are victims of environmental destruction. This is important as environmentalists often focus only on natural environmental concerns but overlook the victims who are equally as vulnerable and defenseless. According to the philosopher Edward Said, intellectuals have two responsibilities on this point: firstly, to stand by the disadvantaged people; and secondly, to influence academics and people with power, all of whom can have a role in making the victims' voices heard. ${ }^{89}$

Thirdly, and most importantly, Minamata-gaku is a discipline based on Japanese empirical values. For a nation whose people lived through the catastrophic environmental problems of the 1960s and 1970s, the knowledge and experience of how to overcome those problems makes for a convincing philosophy, far better than a theoretical philosophical belief system. Minamata-gaku is a discipline that seeks to benefit the future by learning from past mistakes, ${ }^{90}$ a future for the environment and a future for the next generations. A shining example of the use of that discipline is Minamata City. That city is now not only supported by stringent government regulations, but also by a determination from its citizens to make their community an environmentally sustainable society. An instance of

\footnotetext{
${ }^{86}$ Harada, Inochi no tabi-Minamata-gaku he no kiseki (The path of life, traced through Minamata-Studies), p. 38.

${ }^{87}$ V. Plumwood, Environmental culture, The ecological crisis of reason, Routledge, London, 2002, p. 65.

${ }^{88}$ M. Harada, Minamata no kyōkun kara atarashii gakumon he no mosaku (Seeking a new learning from the lessons of Minamata), http://www3.kumagaku.ac.jp/minamata/link/gaiyo/gaiyo-02.htm, (accessed 28 May 2007).

${ }^{89}$ Harada, Inochi no tabi - Minamata-gaku he no kiseki (The path of life, traced through MinamataStudies),p. 65.

${ }_{90}$ Minamata-gaku, http://www3.kumagaku.ac.jp/minamata/02minamatagaku/minamatagaku.html, (accessed 20 May 2007).
} 
that determination is that the residents now sort their garbage into 22 different categories, ${ }^{91}$ for better recycling and disposal. In a nation wide competition to find the most desirable city in Japan, Minamata city with a population of 30,000 was given the top award. Especially high in merit were its environmental management system and its preservation of the natural environment. It recorded the highest total with an assessment of 95 percent. ${ }^{92}$ Sustainability through careful planning and the resolve of the local community were certainly key elements in this achievement. By and large regional governments and local councils are more active in environmental initiatives than is the Japanese central government. Purnendra Jain has made the point that local governments are political players. ${ }^{93} \mathrm{He}$ also emphasized the significance of local government activity in environmental issues, stating that Minamata city invited overseas trainees (mainly from Asia) to share its experience and learn about environmental management. ${ }^{94}$ This is one characteristic of the Japanese way of environmental ethics - Minamata-gaku.

There are two other elements that have formed the Japanese way of environmental ethics. They are Jimoto-gaku (Local Studies) and Satoyama (Local Values). They are significant along with Minamata-gaku, in fact they were based on the lessons learnt from the Minamata experience. Tetsurō Yoshimoto, a Minamata city public servant of the 1990s, advocated the notion of Jimoto-gaku; it focused closely on local issues. Issues include how the region wished to develop, how to sustain the local environment, and how to maintain the economy and the livelihood of current and future generations. Yoshimoto stressed that decades ago when the people in the region suffered from the effects of Minamata disease, and from social discrimination, rather than just complain they made a positive attempt to determine the best plan for their city. They worked hard to rebuild their regional culture, industry and environment. ${ }^{95}$

\footnotetext{
${ }^{91}$ Minamata shi, Gomi no hunbetsu nit tsuite (Minamata city, sorting out of rubbish), 2007 http://www.minamatacity.jp/ipn/kankyo etc/gomi/gomi top.htm, (accessed 29 May 2007)

${ }^{92}$ Kankyō shimin, Dai 5 kai Nihon no kankyō shuto kontesuto (The $5^{\text {th }}$ Japanese contest for the best environmental capital cities), 2007, http://www.minamtacity.jp/ipn/kankyo etc/shuto contest/contest.htm, (accessed 4 June 2007)

${ }_{93}$ P. Jain, Japan's subnational governments in international affairs, Routledge, London, 2005, p. 93.

94 Ibid., p. 93.

${ }^{95}$ T. Yoshimoto, "Chiisana sekai heno kaiki (The return to the small world)", Kankyo, no.28, July 2003, p. 9.
} 
The Japanese study of Satoyama has received significant attention from Japanese scholars: the literal translation of the term being 'village and mountain' and refers to a sustainable way of living. Tokuji Maruyama pointed out the important relationship between Satoyama and environmental ethics. He stated that Satoyama refers to the copse, the agricultural and secondary forest areas in the hills behind farmhouses where care of this area was essential for farmers to successfully grow rice and dry land crops. ${ }^{96}$ This is another aspect of local environmentalism at work and emphasizes its importance for a sustainable regional society; sustainability is a fundamental essence of environmental philosophy. A policy decided on and put into effect by a community for that community, is the most ethically promising and practical philosophy within this model.

\subsection{A comparison of the two models - development and outcome}

A major difference between the two environmental ethical principles is that the Western model belongs to a part of philosophical thought whereas the Japanese one developed from empirical experiences. A further difference is that Western environmental ethics developed through interaction among philosophers, whereas Japan's developed through the interaction of victims of environmental damage with scholars and the medical profession.

The Western model of environmental ethics evolved through the writings of academics and philosophers; these writings were largely based on Judeo-Christian ideas and traditions. Their individual philosophies were influenced by the network of Western thinkers who had approached the developing debate on environmental concerns from different perspectives. 'Western Environmental Ethics' developed to encompass a broad spectrum of ideals ranging from Deep Ecology to Land Ethics (refer to Table 1). The Western model was initially guided by a 'top down' approach but as it gained acceptance it was strongly supported by broad sections of the public; people could find in 'environmental ethics' a field about which they felt passionate. The Japanese model by contrast developed through a 'bottom up' approach; it was built on empirical values at the community level. Although the dogma was articulated by thinkers, it nevertheless was an initiative from the grass roots society. The sufferers and those people associated with the victims of industrial

\footnotetext{
${ }^{96}$ T. Maruyama, "Kankyo no yutakasa wo motomete - moderu to shiteno Satoyama (The pursuit of a healthy environment - Satoyama as a model)", Ningen kaigi, Winter December, 2003, p. 206.
} 
imprudence set about correcting the ills that had caused the problems. This is exemplified in Minamata-gaku.

Western environmentalists have often made the mistake of believing that their philosophy can be transported unchanged to the East, but they overlook the rich philosophy of people who have previously had a strong empathy with nature. The Western notion of 'taming nature' is less sensitive to the environment than the Eastern notion of 'living with nature'.

There is a perception in some of the Western nations that environmental ethics is universal, but some writers have questioned and criticized the Japanese perception of a moral stance when it comes to environmental issues. For example, Maggie Suzuki from The Japan Environment Monitor makes the bold assertion that environmental ethics is based on universal principles involving science and reverence for life, and on that basis she concludes that Japan is a society devoid of ethics. ${ }^{97}$ Japan has its own style of environmental ethics, and when comparing the ethics of Western countries with those of Japan, there are clearly dissimilar perceptions when dealing with environmental issues. However, in this area Japan's does represent a new and different view.

Another view is found in Singer's book How are we to live? He believed that Japan's poor record on global environmental issues was due to its sense of 'groupism'. Singer claimed that the so called 'group society attitude' among the Japanese people could be the reason for their relatively weak sense of responsibility in the interests of the global environment. ${ }^{98}$ What Singer has overlooked or underestimated is the unique and significant characteristics of Nihonjinron. As mentioned earlier, a distinctiveness of Minamata-gaku is the value placed on empirical values, values that appreciate the positive aspect of a group orientated society. The people who lived through Japan's appalling post war environmental problems have used their knowledge and experiences to overcome these problems; it makes for a sound and convincing philosophy. What Singer may have meant was that the Japanese government policy on global environmental issues has a poor record, not the Japanese citizens themselves.

\footnotetext{
${ }^{97}$ M. Suzuki, "Contradictions, ethics, and environmentalism in Japan", Japan environment Monitor, vol. 5, no. 8 (\#50), January 1993, p. 12.

${ }_{98}$ P. Singer, How are we to live: ethics in an age of self-interest, Mandarin, Port Melbourne, 1995, p. 151.
} 


\section{Conclusion}

Many philosophers hold that in the making of a policy that deals with environmental concerns, a philosophical contribution is as important as a technical one. The Western discipline relating to environmental ethics came as a result of the emerging environmental movements championed by the engagement of philosophers, theorists, ethicists, and environmentalists who were concerned about the state of environment. Religious beliefs have been instrumental in forming that discipline and an ethical attitude towards nonhuman beings is an accepted moral requirement. Religion has also shaped the Japanese model but that code needs to be understood in the concept of rinri, an all-encompassing notion that covers the relationship between mankind, and mankind and the natural world.

This chapter has identified the unique Japanese model of environmental ethics built upon experiences of Minamata disease and a central tenet of the theories of Minamata-gaku; it encompasses the responsibilities of government and businesses on environmental issues, and supports the disadvantaged victims of environmental degradation. The Western and Japanese environmental ethics codes are each quite distinctive from each other: the Western code evolved from a theoretical base whereas the Japanese code was built on empirical experiences. Moreover, the traditional Japanese approach to the ecosystem has been one of harmony, reciprocity, care and respect, while the Western approach has been one of admiration and domination and involves more of a one way action. Although their perceptions towards environmental morality differ, the key to any moral convention is the inclusion of the imperative 'sustainability'. Sustainability must strike a balance between utilization and conservation of natural resources, and that includes the animal species. This balance must be born in mind when one considers that the use of stored energy such as oil has allowed mankind until now to expand beyond earth's normal carrying capacity: in the future, however, the human race will need to guarantee that the consumption of finite natural resources does not exceed nature's ability to replenish them. An environmental policy that will ensure the continuity of the human race will contain the ethics of philosophical wisdom along with an acknowledgement of man's dependency on the natural world: the element of sustainability is an essential ingredient.

If harmony, reciprocity, care and respect are traditional elements in the Japanese approach to environment, then sustainability is also a key essence of environmental ethics. The next 
chapter deals with Japan's domestic environment policy and seeks to assess its ethical framework. The policy came into being in 1971, at the same time that the Environment Agency was established. The domestic policy came about as a result of bottom-up initiatives; however, during its development it had to accommodate to Japanese industry and as a consequence its ethical intent was diluted. 


\section{CHAPTER TWO}

\section{JAPAN'S DOMESTIC ENVIRONMENT POLICY}

Japan is today a highly developed, technologically-driven industrialised nation known for its soundly-managed environmental regulations; that was not however the situation in the past. In the period following World War II Japan's unbridled industrialisation led to some of the world's worst environmental pollution incidents. The term used to describe them is kōgai (公害: public poison). In the late 1960s, social pressure on the Japanese government regarding these incidents prompted the establishment of the Environment Agency in 1971. To protect the domestic environment, the Agency enforced tight regulations and laws on Japanese industry; by the mid-1990s Japan became known as an environmentally-friendly nation and as an active participant in global environmental issues. There are numerous studies on Japan and its environment by both Japanese and non-Japanese scholars who have written extensively on the subject. Jun Ui, Masazumi Harada, Ken'ichi Miyamoto, and many others, have written numerous articles on the koggai that occurred from the 1950s through to the early 1970s. However, a feature that has not been questioned is the essential aspect of environment policy making, the inclusion of an ethical framework in its formation. This chapter examines Japan's domestic environment policy to see whether it contains such a framework. Although the policy was set in motion by concerns at the grassroots level, the government policy has been greatly swayed by the country's big business and industry. The intention of the policy was to improve the living conditions within the Japanese society, but it has been compromised by its appeasement to industry and its tendency to discount the future.

This chapter comprises five sections. The first section discusses Japan's four major kōgai. The exposure of the causes of these koggai was historically important as they were until that time Japan's worst environmental pollution cases, and that their exposure became the foundation on which Japan's domestic environmental policy was built. The second section 
outlines the development of the Japanese domestic environment policy from 1945 to the present time. Over the past fifty years the policy focus has evolved through three stages; from the battles with kōgai to kankyō mondai (environmental concerns) and then to dealing with global environmental issues. This section shows not only the policy development, but also how the Japanese policy making process changed through Japan's awakening global consciousness. The third section examines the players who influenced and shaped the domestic environment policy; there are three players in particular who decide the policy's direction and are an important element in deciding its central focus. Although the policy focus is the cliché of sustainable development, these three players interpret it differently. The fourth section analyses the strategies in the policy, and an understanding of it. The final section explores the causes of today's environmental devastation in Japan; public works projects and public policies come under this scrutiny.

\section{Japan's Kōgai cases}

The worst koggai known as the 'Big Four' were, Itai-itai, the two Minamata Disease outbreaks, and Yokkaiichi Asthma; they all occurred in the early post World War II period. These koggai were the result of a rapidly growing industrialised economy aided and abetted by the government. The downside of Japan's 'economic miracle' was that it came at a great cost to people living at low socio economic levels; in many cases it destroyed their health and their livelihoods. The players in Japan's koggai cases can be divided into two, those who caused the problems and those who were the victims. The kogai crimes were led by the Japanese government and by Japanese industry in their single minded pursuit of economic growth.

\subsection{Itai-itai disease}

Itai-itai disease was a notorious kōgai incident that occurred around the Jintsū river of Toyama City in the Toyama prefecture. The disease brings about extreme pain in the victim's bones and causes them to cry out, 'itai-itai' (literal translation, 'it hurts-it hurts'). In 1955 the previously unexplained disease was found to have been caused by poisoning from cadmium contained in effluent discharged into the river by Mitsui Metal Kamioka 
Mining. Jun Ui pointed out that cadmium poisoning had already affected people from at least the Taishō period (1912-1926); it was only in 1945 that people showing symptoms of the disease were first examined by medical doctors. ${ }^{1}$ Itai-itai disease was a disaster waiting to happen: the fault lay not only with the company that was directly responsible, but also with the government bodies that failed in their protection of Japanese citizens and their living environment.

In the severest of cases, because of the persistent pain patients lost their appetites and as a consequence their weight fell dramatically; apart from the pain there was a strong likelihood of the victim's bones fracturing easily. In the worst case recorded, one patient had pressure fractures of the spinal cord, 28 fractures of the ribs, and 72 fractures in the body, before the victim died. ${ }^{2}$ Shigeto Tsuru gave details of the effects of the disease that included grinding joint pains all over the body, especially in the pubic bones, and rib bones that were very vulnerable to fracture; the death rate from the disease was as high as 50 percent. $^{3}$

An analysis of the bones of some Itai-itai patients with serious symptoms showed that they contained as much as 3,800ppm of cadmium, a maximum of 530ppm of lead, and 700ppm of zinc; even patients with minor symptoms showed a contamination level of $300 \mathrm{ppm}$ of cadmium. ${ }^{4}$ In spite of the obvious cause and effect on people and on the environment, both the central and local government were reluctant to acknowledge the facts; they failed to respond to the situation while hundreds of people suffered and died. The key person in coming to the aid of patients with Itai-itai disease was a local medical doctor named Noboru Hagino, who had for decades treated Itai-itai patients in the town of Fuchū. Hagino's persistent devotion to his patients, and his convincing diagnoses and analyses which proved the cause and effect of the Itai-itai disease, were without doubt outstanding. In 1967 he testified to the House of Councillors; up to that time he had diagnosed 205 patients of whom 201 were female, and of whom 117 had died. ${ }^{5}$ In the same year, the Anti-Itai-itai Disease Council of the Toyama prefecture requested for the first time

\footnotetext{
${ }^{1}$ J. Ui, Kōgai genron (The theory of kōgai), Aki Shōbō, Tokyo, 1993, p. 104.

${ }^{2}$ K. Katoh, Nihon kōgai ron (The theory of Japanese kōgai), Aoki Shoten, Tokyo, 1977, p. 29.

${ }^{3}$ S. Tsuru, "History or pollution control policy", in Tsuru and Weidner (eds), Environmental policy in Japan, Edition Sigma, Berlin, 1989, p. 26.

${ }^{4} \mathrm{Ui}$, Koggai genron (The theory of koggai), p. 110.

${ }^{5} \mathrm{~S}$. Tsuru, The political economy of the environment, the case of Japan, the Athlone Press, London, 1999, $\mathrm{p}$. 102.
} 
compensation for victims. The Council took Mitsui Mining to court and represented relatives of victims who had died, as well as those who needed medical treatment. ${ }^{6}$ It is apparent that by the end of the 1960s the anti-koggai movements had developed enough power to give support to the kōgai patients.

In May 1968, thirteen years after the identification of the cause of the disease, the Ministry of Welfare for the first time officially acknowledged Itai-itai disease. The Ministry later stated that the cause of the disease was cadmium poisoning, principally from discharged waste by Kamioka Mining. ${ }^{7}$ In the year following that acknowledgement, neither the White Paper of the Minister of Welfare, nor the Kōgai Hakusho (Kōgai White Paper), explained exactly what the Itai-itai disease was. This particular outbreak was one of many other Japanese koggai that were similarly caused by corporate neglect and government indifference.

In comparison to Minamata disease, Ui emphasized that the characteristics of Itai-itai were that the patient's ailment was not visible and it came to be regarded as an unfortunate illness carried over from a previous life. ${ }^{8}$ This Buddhist belief appeared to offer a rationale for the disease in the early stages of the outbreak as no one at that time understood the illness.

1.2. Minamata disease in Minamata City and Niigata City.

The Minamata disease became recognised as a typical kōgai illness after it had appeared in two Japanese regions. The outbreaks attracted great attention in both the domestic and overseas media and ensured long lasting court hearings. The disease occurred in Kumatmoto prefecture in the Southern part of Japan, and in Niigata in the far Northwest of Tokyo. According to a report in March 1999 from the Environmental Health Department in the Agency for the Environment (later to become the Ministry of Environment), 2,952 people have been officially certified as Minamata patients, of whom 75 percent were

\footnotetext{
${ }^{6}$ Tsuru, The political economy of the environment, the case of Japan, p. 102.

${ }^{7} \mathrm{Ui}$, Koggai genron (The theory of kōgai), p. 118.

${ }^{8}$ Ibid., p. 132.
} 
located in the Yatsushiro Sea area in Kumamoto prefecture, and 25 percent in the Agano River basin area in Niigata prefecture. ${ }^{9}$

The disease was named after the first outbreak that occurred in Minamata City; it is a disorder of the central nervous system caused through the consumption of fish and water that have been contaminated by the chemical substance methyl-mercury.

The first case of Minamata disease was noted in 1954 when a man with the early symptoms of the disease was hospitalized in the neuro-psychiatry department of the medical section in Kumamoto University. ${ }^{10}$ It was as then an unknown disease. However, in May 1956 four patients were brought to the city hospital also with an unknown disease but all displaying similar symptoms, viz. severe convulsions, intermittent loss of consciousness, a demented mental state, and later a permanent coma. ${ }^{11}$ There were at least two common factors to the Minamata outbreak. The first was that the patients had eaten fish caught in Minamata Bay, and the second was that they had used water from the bay. Shigeto Tsuru pointed out that, with the breakdown of the central nervous system, the death rate of victims from the disease was as high as 40 percent. The disease was concentrated among the fishermen who resided in the town. ${ }^{12}$ As early as 1953 the strange behaviour of cats, dogs and other animals in the area was noticed and that this behaviour often preceded convulsive death. It was later revealed that the fish and water had been contaminated by the discharge of untreated waste liquids from the Nippon Chisso Corporation.

The mercury compounds in the effluent discharge from an acetaldehyde production unit were the cause of the disease. ${ }^{13}$ Minamata shared a similar characteristic with other towns that had 'disease' problems in that it was a 'Corporation town'; the close interaction and relationship between Chisso and the City had brought prosperity to both. Whilst in the 1950s economic development was the highest priority for the Japanese government and in

\footnotetext{
${ }^{9}$ Unpublished paper, 'Our intensive efforts to overcome the tragic history of Minamata disease', by Environmental Health Department, the Environment Agency, 1999, p. 3.

${ }^{10}$ M. Harada, Inochi no tabi - Minamata-gaku he no kiseki (The path of life, traced through MinamataStudies), Tokyo Shimbun Shuppan kyoku, Tokyo, 2002, p. 25.

${ }^{11} \mathrm{~J}$. Ui, "Minamata disease", in J. Ui (ed.), Industrial pollution in Japan, United Nations University Press, Tokyo, 1992, p. 110.

${ }^{12}$ S. Tsuru, "History or pollution control policy", Tsuru and Weidner (eds), Environmental policy in Japan, p. 23.

${ }^{13} \mathrm{Ui}$, “Minamata disease", in J. Ui (ed.), Industrial pollution in Japan, p. 113.
} 
turn Japan's manufacturing industry, Minamata's humble but important fishing industry was ignored. As a result of the pollution, the small fishing community was devastated. A further problem was not only the disease itself, but the close relationship between the Chisso Corporation and the Minamata City authorities. In the 1950s the Chisso Minamata complex enjoyed its greatest economic success: 60 percent of all Minamata city taxes came from Chisso; the success of the Corporation ensured the prosperity of the City. ${ }^{14}$ It was in the interests of the local government authorities to be lax in enforcing environmental safeguards, but Chisso was the primary body responsible for causing the disease.

The second outbreak of Minamata disease occurred in 1965 in the Agano River basin on the outskirts of Niigata City. Unlike the first outbreak, this time an acknowledgement from the government was reasonably prompt. The basic cause was the same as that in Minamata City; methyl-mercury produced as a by-product in manufacturing of acetaldehyde by the Shōwa Denkō Company was released upstream of Niigata into the Agano river. As a result, the residents in that region who consumed large amounts of contaminated fish had their central nervous systems damaged.

The number of victims in both Minamata and Niigata are not really known, but many hundreds died in agony without any recognition or treatment. It was not only a poison that killed people, but it was one that also destroyed the livelihoods of whole communities. It is important to note that by allowing the second outbreak of Minamata disease to happen, the Japanese government revealed that it had not learnt the lessons from the first catastrophe. The priority given to Japan's economic development blinded the eyes of members of the government who failed to acknowledge and to remedy the unethical conduct of the large companies.

It took until 1968, 12 years after the initial discovery of the Minamata disease, for the Japanese government finally to give full recognition to the cause and effect of the disease. $^{15}$ It is estimated that there have been more than 20,000 Minamata victims in Japan, and it is believed that the number of people adversely affected by the disease will increase.

\footnotetext{
${ }^{14} \mathrm{Ui}$, "Minamata disease", in J. Ui (ed.), Industrial pollution in Japan, p. 109.

${ }^{15}$ Ibid., p. 117.
} 
In 2006 a 50 year commemoration of the outbreak of Minamata disease took place in Minamata City. The Minister of Environment, Yuiriko Koike, attended the ceremony as a representative of the Japanese government and addressed the assembly. In spite of the fact that Minamata City is today known as one of the cleanest cities in Japan, there is the little known fact that there are many sufferers still waiting to be identified as Minamata disease patients. The Japanese scholars Jun Ui and Shūichi Kitoh agree that even though 50 years have passed since the Minamata outbreaks, there are many tasks and issues that need to be resolved due to the government's reluctance to accept responsibility. ${ }^{16}$

\subsection{Yokkaichi asthma}

The Yokkaichi region in 1959 was the first region to develop a coastal industrial complex. It was built on the coastline of Ise Bay in Mie prefecture. Yokkaichi was selected to be the site for huge petrochemical pumps and oil refineries; at that time a modern petrochemical industry was considered to be one of the most important requirements for revitalizing Japan's economy. There were two stages in the building of the complexes: the first was completed in 1961 and the second in 1963 when operations commenced. ${ }^{17}$ As a consequence, from 1963 onwards air pollution became noticeable and affected residents, agriculture, and particularly the fishing industry.

Along with Itai-itai disease and Minamata disease, the common thread with Yokkaichi asthma and the other koggai was Japan's rapid acceleration of economic growth. The Yokkaichi region was developed as a massive industrial complex with the consequence that the neighbouring communities were exposed to enormous pollution that caused their health to suffer, and for their environment to be degraded. Residents first started to complain of respiratory problems early in the 1960s. Yoshiro Hoshino pointed out that in the beginning the ailment was known as 'beach salt disease'; it was later discovered that the disease was caused by sulphuric acid gases. ${ }^{18}$ The majority of the victims came from the fishing community in the suburb of Isotsu located in the Southeast of Yokkaichi City.

\footnotetext{
${ }^{16}$ J. Ui. and S. Kitoh, "Minamata ni dai san sha wa inai (Minamata does not have the third party)", Gunshuku chikyu shimin, no. 6, Autumn, 2006, p. 10.

${ }^{17} \mathrm{~S}$. Tsuru, The political economy of the environment, the case of Japan, p. 71.

${ }^{18}$ Y. Hoshino, "Japan's post-second world war environmental problems", in J. Ui (ed.), Industrial pollution in Japan, p. 69.
} 
It had 680 households of 2,700 residents contained in one square kilometre: these were the most seriously affected victims by the petrochemical pollution. ${ }^{19}$ The Yokkaichi kōgai not only destroyed the inhabitant's health, but it also damaged the intrinsic value of the local environment, the cultural and social value of the fishing tradition, and the livelihood of the fishermen themselves.

The number of Yokkaichi asthma patients in 1975 was recorded as being 1,140, while in 2004 it was believed to be around $500 .^{20}$ In spite of the many law-suits that were issued and are pending, the Japanese government in 2004 abolished the identifying system of the Yokkaichi kōgai; as a consequence there are many surviving patients whose illness has not been acknowledged by the government.

\section{The development of the domestic environmental policy}

In Japan environmental pollution problems had first been noted in the 1890s. However, in the post war period the problems grew to an alarming extent as pollution increased along with Japan's rapid industrialization. Japan's domestic environment policy was established in response to the health problems and was developed through the use of laws, regulations, and technology. This section covers the era from the end of the War in 1945, and is divided into three periods in order to see how the Japanese policy came to grips with the domestic pollution problems.

\subsection{Kōgai; environmental pollution (1945-1971)}

By the mid-1950s, due to the government's strong emphasis on economic growth the Japanese economy had shown a remarkable recovery. The government believed that heavy industry was a key tool for Japan to regain its pre-war economic levels, and the Korean War (1959 - 1953) helped fuel this growth. Chalmers Johnson pointed out that during the Korean War the United States placed with Japanese industries extensive orders for

\footnotetext{
${ }^{19}$ Yokkaichi kōgai, available at: http://www.yokkaichikougai.tcup.ca/contents1/guide/1 zensoku/contents/preguidecss.htm, (accessed 26 November 2007).

${ }^{20}$ Yokkaichi kōgai.
} 
ammunition, trucks, uniforms, communications equipment, and other products needed for the war effort. ${ }^{21}$ During this period of high economic growth the petrochemical industry was a significant force in Japan. However, that industry was the cause of numerous pollution related diseases that broke out in several regions and these kogai were the catalyst for the establishment of the Japanese environmental policy.

In the absence of a designated authority to deal with environment related problems, the Ministry of Welfare (MOW) became the responsible authority until 1971 when the Environment Agency was established. The MOW focused on the health and welfare of the Japanese people and not on the environmental pollution itself; it was a case of prioritising the effect rather than the cause. The MOW within the government was not able control the $k \overline{o g a i}$, but it enacted laws in an effort to minimize their effects. They were introduced which aimed at managing environmental pollution and at controlling industrial activities.

In 1958 the MOW enacted the first of three laws that were significant in influencing the early stages of the development of Japan's domestic environment policy. With the outbreak and recognition of Minamata disease, the government was compelled to act. However, in the early stages the government authorities were reluctant to accept that the Minamata and Itai-itai outbreaks were caused by pollution: they considered them to be diseases.

The first law designed to prevent further kōgai incidents was the Water Quality Conservation Law (WQCL) of 1958. The main purpose of the WQCL was to investigate the pollution content of sewage and factory effluent that flowed into public waterways, and then for the MOW to place regulations on those discharges. ${ }^{22}$ The Government enacted the law not because it believed that it was needed, but in response to public pressure. In June 1958 hundreds of fishermen protested against the Honshū Seishi Edogawa Factory in Tokyo, as the paper manufacturing plant had continually released contaminated waste water into the river with the result that it had devastated their fishing industry. Eight hundred fishermen representing the fishing community went to the factory to complain:

\footnotetext{
${ }^{21}$ C. Johnson, MITI and the Japanese miracle, the growth of industrial policy, 1925-1975, The Charles E. Tuttle Company, Inc., Tokyo, 1991, p. 200.

${ }^{22} 1968$ Kōgai White Paper, http://www.env.go.jp/policy/hakusho/honbun.pho3?kid=144\&bflg=1\&serial=11261, (accessed 20 February 2009).
} 
they were not only ignored by the factory management but also by the government authorities; neither entity took any action in response to the fishermen's outcry. ${ }^{23}$ The Urayasu City municipal government in Chiba prefecture reported that the riot led to about 150 people being injured and 8 being arrested. ${ }^{24}$ The Japanese authorities were unwilling to concede that the fishing industry had been adversely affected by contaminated water. This koggai incident is but one example of the government's reluctance to take action to remedy the causes of the kōgai. Jun Ui believes that kōgai got worse when government authorities and companies mutually supported each other. ${ }^{25}$

Although the MOW's responsibility covered koggai incidents, the passing of the regulations and laws was very much controlled by the Director General of the Economic Planning Agency. The signatories to the WQCL comprised the Prime Minister and six ministries, the ministries of Finance, Welfare, Agriculture and Fisheries, International Trade and Industry, Transport, and Construction. ${ }^{26}$ Japan was at that time heavily dependent on the domestic fishing industry which explains the reason for the involvement of those six ministries. The purpose of the WQCL was to prevent koggai, but it also benefited Japan's business groups. The law was nevertheless a significant measure to combat and control water pollution.

The second law that the Central government introduced was the Basic Law for Environmental Pollution Control (BLEPC), enacted in 1967. ${ }^{27}$ Areas of responsibility that the Law covered included air, water, sewage, and noise; it stated that they were the responsibility of both central and local governments, business, and the public. What was not clearly spelt out in the Act was a willingness to reduce kōgai. There was a clause that called for harmony between the economy and $k \overline{o g} a i,{ }^{28}$ but this could be interpreted to be a law for Japanese businesses to control pollution rather than to prevent it. The Law assumed that the public would accept the fact that economic growth would bring koggai.

\footnotetext{
${ }^{23}$ Urayasu city, Chiba prefecture, available at: http://www.city.urayasu.chiba.jp/2000/2004/mukashi banashi/nepyo kaisetu.html, (accessed 16 November 2007). 
The third law that was established was the Water Pollution Control Law (WPCL) in 1970. The purpose of this law was to maintain community water quality by preventing factories from discharging polluted liquid waste into municipal water areas. ${ }^{29}$ Public water zones such as rivers, lakes, coastal water areas, and reservoirs were monitored to ensure quality control. A distinctive feature of this law was that it gave the Governor of the local government control over these areas; thus it appears that the responsibility was passed from the central government to local governments. However, what the WPCL did not make clear was the role and responsibility of the central government.

The year 1970 signalled an important time for water quality control measures in Japan; laws were enacted to control water pollution and local governments were given jurisdiction over it. Purnendra Jain pointed out that local government in Japan, particularly between the mid-1960s and early 1970s, made a series of innovations in policy sectors, notably in the areas of pollution control. ${ }^{30}$ According to Hikaru Shōji and Kenichi Miyamoto, the so called Kakushin jichitai (progressive local government) took a leading role in environmental pollution control; the Tokyo Metropolitan government's pollution prevention law, and others, spelt out that preventing water pollution and preserving the amenity of the environment were the responsibility of local government. ${ }^{31}$ The metropolitan government took a positive role in controlling environmental pollution in Tokyo. Ryōkichi Minobe, the Governor of Tokyo (1967-1979) showed concern over local environmental problems and put forward the slogan, "Let's bring back blue skies to Tokyo". ${ }^{32}$ Jun Ui pointed out that Minobe put a lot of effort into solving the pollution problems, and that he proposed to enact much tougher laws than the central government had. ${ }^{33}$ However, Minobe's proposals were rejected due to pressure from the business communities. Nevertheless, an extraordinary session of the Diet was convened at the end of the 1970s to combat the country's environment problems; that session is known as the Kōgai Kokkai (Kōgai Diet) with the Prime Minister as the head. One significant aspect of

\footnotetext{
${ }^{29}$ Water pollution control law, by the Ministry of Environment, Government of Japan, available at: http://www.env.go.jp/en/laws/water/wlaw/ch1.html, (accessed 19 November 2007).

${ }^{30}$ P. Jain, Local politics and policymaking in Japan, Commonwealth publishers, New Delhi, 1989, p. 8.

${ }^{31}$ H. Shōji and K. Miyamoto, Nihon no kōgai (Japan's environmental pollution), Iwanami Shoten, Tokyo, 1991, p. 224.

32 R.Pulvers “It was 40 (very different) years Japan's environment pollution ago today....", Japan Times, 15 April 2007, http://search.japantimes.co.jp/cgi-bin/fl20070415rp.html>, (accessed 19 November 2007).

${ }_{33}$ Jun, Ui, "21 seiki wa sizen to seikatsu no tame no kagaku wo (Science in the $21^{\text {st }}$ Century is existence with life)", Nelsis-Net, available at: http://www.nelsis.jp/nelsis/vol3/p12.htm, (accessed 19 November 2007).
} 
the Kōgai Kokkai is that it gave local government further authority to regulate activities that create environmental problems.

\subsection{From kōgai to kankyō (environment) (1971-1989)}

Due to the Kōgai Kokkai, 1971 was a turning point in Japan for environmental contamination control; it opened up a new era in which greater emphasis was placed on the role of government administration of environmental matters. The significant change was from one of just combating environmental pollution, to a forward thinking course of action to safeguard the environment, this action continued through to the $1980 \mathrm{~s}$. The establishment of the Environmental Agency was an important feature in the improvement of the environment policy as it signalled the beginning of a new direction that it was thought would control pollution.

Whilst at this time the Japanese government continued to pursue economic growth, the populace began to place a higher value onto the environment. A survey conducted by the Prime Minister's Office in 1972 found that the majority of the Japanese wanted to "protect the environment rather than just have economic growth". 34 That the public now placed a high value on the environment, as well as on their well-being, was probably due to the four major koggai outbreaks during the 1950s and 1970s. The government nevertheless sought to improve the environment by laws and regulations enforcing pollution control, particularly industrial and urban pollution. Two features influenced and shaped the development of Japanese domestic policy.

The first was the outcome of the kōgai law-suits. The four major court decisions in the late 1960s and the 1970s prompted the government, and in turn the environmental policy makers, to implement some initiatives. There is no doubt that the Japanese national media played a crucial part in them by publishing unbiased and accurate facts on justice relating to environmental matters. From the beginning of the 1970s environmental awareness grew tremendously; it was supported by media reports and was also helped by social movements that were concerned about the environment. An example is the Itai-itai disease court case

\footnotetext{
${ }^{34}$ N. Kamioka, Nihon no Kōgai shi (History of Japan's kōgai), Sekai Shoin, Tokyo, 1987, p. 251.
} 
where a lawsuit was first filed against the Mitsui Metal Kamioka Mining Company in 1968. In 1972 the court found that Mitsui had full responsibility and was ordered to pay compensation of about $\$ 1.5$ million to the victims. ${ }^{35}$

In July 1972, the 'Yokkaichi asthma' lawsuit (explained later) gave a great victory to the plaintiffs as it showed that the responsibility lay not only with industries, but also with the various levels of government. As a consequence, in 1973 the Japanese government enacted the 'Environment Health Damage Compensation Law', the first such law in the world. The maximum compensation was to cover 80 percent of the victim's average salary, and also to cover some medical costs. ${ }^{36}$ In the 1970s the four major koggai lawsuits appeared to end in victory for the plaintiffs; however, the hidden social costs of environmental degradation and human health have not as yet been fully resolved.

The second feature of Japan's environmental contamination is the urban pollution that had become apparent during the 1970s and 1980s. In terms of the Government's position on this aspect, the 1970s were a turning point as the policy focus shifted from kogai into broader societal problem areas such as air, noise, and waste. Kunioki Katō made a clear distinction between kōgai and environmental problems. Kōgai is a social problem that clearly divides victims and defendants, while environmental problems are the problems between human society and the natural environment. ${ }^{37}$ In an effort to combat the growing pollution, the government enacted 21 laws between 1971 and 1989.

Air pollution worsened in the early 1970s and many people, particularly those in Tokyo, complained of the photochemical smog. It was so bad that in August 1972 the Tokyo Metropolitan Government had to announce a photochemical smog warning for eight consecutive days. ${ }^{38}$

Besides the air pollution problems, a new type of environmental concern began to emerge in the Japanese society. As the public began to indulge in growing consumerism, the consequent problems of increased waste and its disposal emerged. To illustrate the

\footnotetext{
351973 Kankyō hakusho (Environment White Paper), at: http://www.env.go.jp/policy/hakusyo/hakusyo.php3?kid=148, (accessed 28 November 2007)

${ }^{36}$ K. Miyamoto, Nihon no kankyō seisaku (Japan's environmental policy), Ōtsuki Shoten, Tokyo, 1989, p. 23.

${ }^{37}$ Katōh, Nihon kōgai ron (Theory of Japan's kōgai), p. 25.

${ }^{38}$ Kamioka, Nihon no Kōgai shi (History of Japan's kōgai), p. 252.
} 
problem, in 1960 the daily per capita waste produced amounted to $400 \mathrm{~g}$ but by 1977 it had reached $1.7 \mathrm{~kg}$; during the $1970 \mathrm{~s}$ the Tokyo Metropolitan area alone disposed of 16,000 tons of garbage daily. ${ }^{39}$ Alan Rix mentioned this problem when he pointed out that the Governor of Metropolitan Tokyo, Ryōkichi Minobe, had instituted a progressive regime in 1970. In October of that year he established the Environmental Protection Bureau to be responsible for environmental problems; it was the first to be established under a Japanese local government. ${ }^{40}$ Furthermore, in the following year Minobe enacted a 'Gomi-sensō' (War on Garbage) policy to tackle the waste in 23 Tokyo wards. ${ }^{41}$

In terms of noise pollution, the 1970 s also brought a new challenge to policy makers. Noise from factories, construction works, motor vehicles, trains, airplanes and other sources were creating major problems. Airplane noise was especially troublesome; complaints jumped from 274 cases in 1977 to 865 in the following year. ${ }^{42}$ A reason for the great rise in the numbers in 1978 was that in that year Tokyo International Airport (Narita) started operating. The Japanese government enacted eight laws and regulations just for noise control between 1972 and $1980 .^{43}$

Due to technological innovations to combat environmental problems, and the growing public awareness of the environmental damage caused during the 1980s, there has been a significant improvement in the severity of domestic environmental pollution. However, in the late 1980s at the time of high economic growth, other environmental problems began to emerge under the banner of 'public works' (discussed later).

2.3. From the domestic to the global environment (1990-.)

The Japanese domestic environmental policy had a further change of focus in the late 1980s. Until this time the Japanese government had concentrated on domestic problems,

\footnotetext{
${ }^{39}$ Y. Hoshino, "Japan's post-second world war environmental problems", in J. Ui (ed.), Industrial pollution in Japan, United Nations University Press, Tokyo, 1992, p. 73.

${ }^{40}$ A. Rix, "Tokyo's governor Minobe and progressive local politics in Japan”, Asian Survey, vol. 15, no. 6, 1975 , p. 535.

${ }^{41}$ Ibid., p. 535.

421980 Kankyō hakusho (Environment White Paper), at: http://www.env.go.jp/policy/hakusyo/hakusyo.php3?kid=155, (accessed 3 December 2007).

${ }^{43}$ Sōon (Noise) in Hōrei (Law), the Ministry of Environment, http://www.env.go.jp/hourei/sogo mokuji.php?mn=07, (3 December 2007).
} 
but the government now became an active contributor in the fight against global problems such as climate change. Japan's domestic policy quickly morphed to accommodate to the new challenge; the government stated that it would participate in, and contribute towards, combating global environmental pollution. Japan's 1988 environmental policy White Paper stated that Japan was economically powerful and was confident that it could contribute to preserving the natural environment by using its technological knowledge and past domestic experiences. ${ }^{44}$ Four factors shaped the change.

The first factor was that the Environmental Agency strengthened its position on environmental protection by formulating far reaching laws. The Japanese government had strategically used regulations and laws to control the domestic environmental problems and legislation had successfully reduced much of the country's environmental pollution. Between 1945 and 2005, the Japanese government enacted nearly 100 environment related laws. Of these, 32 were enacted between 1989 and 2005 and their purpose was to protect both the domestic and global environments. ${ }^{45}$ The Japanese government favours laws as a means to effectively protect the natural environment and to control its desecration.

The second factor was the enactment of the Basic Environmental Law (BEL) in 1993; this law showed a greater determination to shape domestic environmental policy. It was based on the 1967's BLEPC, the first time it had been revised in 26 years; the new law became an important piece of legislation for environmental protection. It appears that the government wanted to reshape Japan's image into one of being a 'green nation' to counter its bad image brought about by the perception that the country was a rapacious consumer of overseas natural resources. As the 1994 Kankyō Hakusho (Environment White Paper) stated, the incentive for the BEL was, as the Prime Minister emphasized, an old law that needed to be revised in the light of the new era of global environmental awareness. ${ }^{46}$ Sustainable development became the key phrase for the BEL. It was designed for the future and emphasized public participation and international contribution to environmental management; it appears that the government had forgotten the valuable lessons learned from the koggai of 50 years ago.

\footnotetext{
${ }^{44}$ The 1988 White Paper of the Environment Agency, http://www.env.go.jp/policy/hakusho/hakusho.php3?kid=163 (accessed 3 January 2007).

${ }^{45}$ The Ministry of the Environment, Hōrei (Law), http://www.env.go.jp/hourei/, (accessed 28 November 2007).

${ }^{46} 1994$ Kankyō hakusho (Environment White Paper), http://www.env.go.jp/policy/hakusyo/hakusyo.php3?kid=205, (accessed 28 November 2007).
} 
It is true that Japan has to a large extent overcome its worst pollution problems and the associated legal actions, but there are koggai court cases yet to be finalised. It could be said that along with the majority of developed nations, in the 1990s Japan was swept along in the upsurge of global environmental awareness. Together with the country's global environmental focus, the domestic policy developed further with its aim of achieving sustainable development.

The third factor was the enactment of the Environmental Impact Assessment Law (EIAL) of 1997. This was the first law in Japan that attempted to protect the domestic environment during development projects. The history of this important and effective law can be traced back to 1972 . At that time environmental assessment only applied to public works projects, but by 1980 it also included nuclear power plants, bullet trains, land reclamation, and harbour facilities. ${ }^{47}$ In 1981 the Environment Agency made an attempt to legalize the assessment, but two years later it was rejected as the result of pressure from Japan's business groups. The enactment of the BEL in 1993 was an important turning point for the EIAL as it emphasized the significance of assessment. As a result, in 1997 the Japanese government proclaimed the law and in 1999 enacted it; the whole process had taken nearly 20 years.

According to the Environment Agency, the purpose of the EIAL was to ensure that proper consideration was given to the protection of the environment for current and for future generations. ${ }^{48}$ This law not only clearly defined the process and assessment of projects, but also identified the responsibilities of the different levels of governments, and that of business. The EIAL applies to many development projects that involve the natural environment which had previously been authorized under either the central or local governments. There is no doubt that such an enforcing law is essential to achieve an ecologically sustainable environment, particularly in regional development public works projects.

\footnotetext{
${ }^{47}$ Kankyō Asesumento Gaido (Environmental Assessment Guide), at: http://www.env.go.jp/policy/assess/11guide/1-2.html, (accessed 29 November 2007).

${ }^{48}$ Environmental Impact Assessment Law by the Ministry of Environment, available at: http:y//www.env.go.jp/en/laws/policy/assess/chap1.html, (accessed 29 November 2007).
} 
The final factor was the establishment of the Ministry of Environment (MOEN). Its transfer from an agency to a ministry gave an encouraging message about the development of the Japanese environmental policy although the Ministry continued to have very much the same responsibilities and obligations as were previously carried by the Agency. Since the establishment of the MOEN, the policy has sponsored a 'soft power' approach; it has created a successful working relationship with the public though programs known as the 3R Inishiatyibu (3R Initiatives) that stand for Reduce, Reuse and Recycle. These initiatives were introduced around 2004 by the Koizumi government. As a result of the Inishiatyibu campaign, social movements for environmental protection started canvassing to reduce waste through two national promotions. These were 'watashi no cappu (my cup)', and 'watashi no baggu (my bag)'; they aimed at reducing preventable waste such as paper cups and plastic bags. The promotions had two aims; firstly to create an environmental awareness in the Japanese society, and secondly to encourage the public to participate in them by bearing in mind the cost of the use of plastic bags to the future health of the environment. Even though the initiatives were proposed by the central government, it relied on an awareness of, and co-operation by, local governments and the community to see that they were successful.

There were some initiatives that allowed the public to become involved in reducing carbon dioxide emissions, and to become aware of the environmental issues of air quality, and waste generation and disposal. To repeat, Japan's domestic environment policy has been greatly influenced by the government's global environmental initiatives.

\section{The trio behind Japan's domestic environmental policy}

Japan's domestic environmental policy needed to be established in order to counter Japan's worst koggai and evolved through the passing of laws and regulations. Besides enacting laws, the environmental policy has continued to focus on science and technological knowhow to solve the problems. There are three main bodies that influence and shape Japan's domestic environmental policy. They are the Environment Agency, later to become the Ministry of Environment that has been the key policy planner; the Ministry of International Trade and Industry (MITI), later renamed the Ministry of Economy Trade and Industry (METI), which plays the mediator and accommodator for Japanese 
businesses; and thirdly the 'Corporate Japan' of Japan's industry and businesses which contributes to the domestic environment policy through self-regulation but which also has a powerful voice over policy direction.

Figure 1: The triangle of players in the Japanese domestic environmental policy

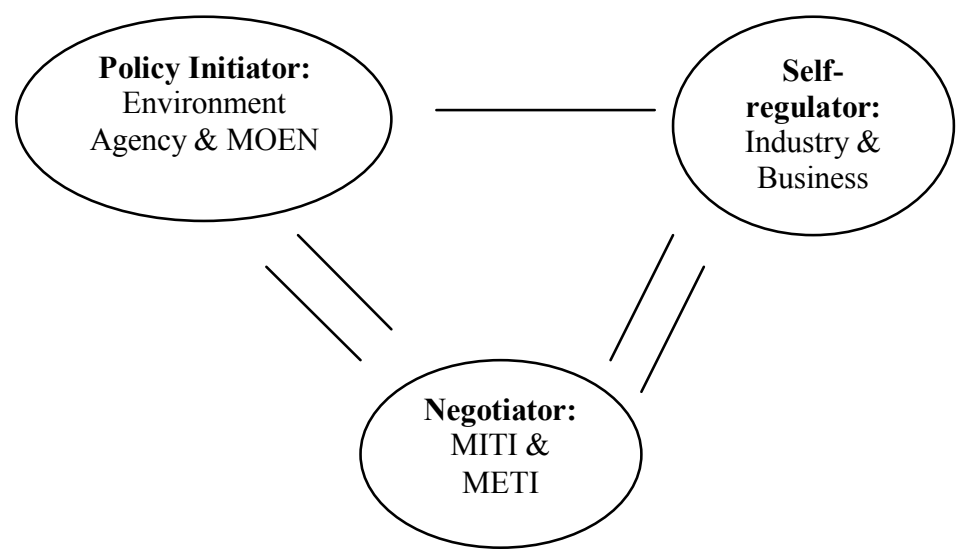

Source: Compiled by the author

3.1. The Environment Agency (1971-2000) and the Ministry of the Environment (2000-)

The establishment of the Environment Agency in 1971 was significant in that it was the first time that a principal government body had been formed to control pollution. The Agency was established under the Prime Minister's Office and its responsibilities were mainly handed over from the Ministry of Welfare which had struggled to deal with the koggai cases. The backdrop to the establishment was public pressure and the political forces resulting from the koggai. Three decades later the Agency was reviewed and renamed the Ministry of the Environment; its role did not change much but its responsibility as a ministry was extended and strengthened. Both the Environment Agency and the Ministry of the Environment played important and central roles as initiators of the policy strategy. There are three elements that explain the reasons for, and the methods adopted by, the Agency and Ministry in order to develop Japan's domestic policy.

Firstly, it is the responsibility of those government bodies to make the decisions on environment issues. The Environment Agency was established to manage, control and 
regulate environmental pollution; despite its expected role, the newly formed Agency struggled at the beginning to exert its power to regulate environmental issues and one of the reasons for that was the structure of the Agency. Shigeto Tsuru pointed out that the Environment Agency had a serious handicap because most of the staff was recruited from other ministries and those staff retained close ties with their 'home offices' ${ }^{49}$ It could be said that the Agency was like a patchwork comprising officers from the economic, health, and agricultural sectors in ministries and agencies. For example, the Agency began in 1972 with 283 officials from the Ministry of Health and Welfare, 61 from the Ministry of Agriculture and Fisheries (MAF), 26 from the MITI, and 21 from the Economic Planning Agency (EPA), as well as others. ${ }^{50}$ Even though the Agency was established as the result of social pressure, as Tsuru has stated the Agency was regarded as quite low in the Japanese cabinet hierarchical structure. ${ }^{51}$ However, the formation of the Agency was not only a result of pressure from the public sector, but may have been a requirement from the Liberal Democratic Party (LDP) as well. According to Hidefumi Imura, at the beginning of the 1970s leading LDP politicians realized the significance of the huge protests against environmental pollution and they feared that the LDP might lose its ability to govern; they acted quickly and initiated the 1970s 'Pollution Control Diet' and established the Environment Agency. ${ }^{52}$ The Agency undertook initiatives to control environmental pollution such as air and water, and collaborated with other ministries, local government bodies, and businesses. Imura pointed out that the 1976 Organization for Economic Cooperation and Development (OECD) policy review showed that the central interest of the Japanese environmental administration was the amenity of neighbourhood and waterside areas, together with planned landscaping. ${ }^{53}$ The Agency has had an important role in shaping Japan's move from a heavily polluted country into a 'green' one. One of the Agency's most important achievements could well be the enactment of the BEL in 1993. The law is not only important in the domestic environment but is also significant in that it has allowed its influence to extend into global environmental issues.

\footnotetext{
${ }^{49}$ Tsuru, The political economy of the environment, the case of Japan, p. 128.

${ }^{50}$ J. Gressor, K. Fujikura and A. Morishima, Environmental Law in Japan, the MIT Press, Massachusetts, 1981, p. 234.

${ }^{51}$ Tsuru, The political economy of the environment, the case of Japan, p. 129.

${ }^{52}$ H. Imura, “Japan's environmental policy: past and future”, H. Imura and M. Schreurs (eds.), Environmental policy in Japan, Edward Elgar, Massachusetts, 2005, p. 29.

${ }^{53}$ Ibid., p. 34.
} 
Secondly, there are the people who put their efforts into developing Japan's environment policy. Buichi Ōishi (1909-2003) was Japan's first Director General of the Environment Agency and he held this office between July 1971 and July 1972. Without his dedication and devotion towards the welfare of his country's environment, the policy might well not have achieved the goals that it did. Ōishi started his career as a medical doctor and later became a LDP politician. He was appointed to the position of Director General when the Prime Minister Eisaku Satō began his third term. In spite of only a one year appointment, Oishi structured the environment policy not only from an administrative point of view, but also from the point of view of the groups of disadvantaged Japanese.

There were two remarkable initiatives which Ōishi instituted to reform the policy. The first was that he reduced the criteria that had been set to acknowledge that a person was suffering from Minamata disease; Ōishi's passion to reduce the suffering of the victims was seen through his actions and speeches. When Öishi visited a funeral service for the deceased kōgai victims he shouted, “Kore wa kokka ni yoru han'zai da (This is a crime led by the nation)"; he also cried at the scene. ${ }^{54}$ Confronting the other ministries and agencies, Ōishi was able to exert sufficient power through his strong convictions even though it was not an easy task. It may well be that as a medical doctor he was able to understand, and to demonstrate, an empathy with humanitarian values as well as being concerned for the wellbeing of the environment. These values were shown when Ōishi declared that the pollution control administration "should be conducted from the viewpoint of the people who are the victims". 55 Furthermore, he promised at the United Nations Conference on the Human Environment (UNEP) at Stockholm in 1972 that he would change the direction of Japanese politics towards more humanitarian values. ${ }^{56}$ Moreover, Ōishi declared at UNEP that the Japanese are once again readdressing the limits of sacrifices and are facing the questions of "for whom" and "for what" economic development should be pursued. ${ }^{57}$ Ōishi's focus and direction in policy formation demonstrated that human values are closely connected to Japanese ethics or rinri; it translates as the maintenance of a healthy relationship with other people in the community (discussed in Chapter 2). Ōishi emphasized a policy that valued human worth as well as environmental worth; his

\footnotetext{
${ }^{54}$ H. Ishi, S. Okajima and T. Hara, Tettei tōron, Chikyū kankyō (Debate on the Global environment), Fukutake Shoten, 1992, p. 52.

${ }^{55}$ Gressor, Fujikura and Morishima, Environmental Law in Japan, p. 241.

${ }^{56}$ Miyamoto, Nihon no kankyō seisaku (Japan's environmental policy), p. 31.

${ }^{57}$ F. G. Notehelfer, “Japan's first pollution incident”, Journal of Japanese Studies, Vol., 1, No. 2, 1975, p. 383.
} 
philosophy can be found in his statement at the UNEP. He stated, both from the viewpoint of a Japanese delegate and as a Director General of the Agency, that the Japanese post-war miracle of industrial growth was 'tragic' 58 .

The second initiative Ōishi took to demonstrate his desire to protect the natural environment was to freeze public works construction undertaken by the Ministry of Construction. For example, he froze the construction of tourist roads in places such as Ozenuma in Gunma Prefecture, Daisetsuzan in Hokkaidō, and the Utsukushi-gahawa Bīnasu River Basin in Nagano Prefecture. ${ }^{59}$ Ōishi believed that the construction of these roads would destroy the local environment, including national park areas. He urged the Minister for Transport to impose stricter noise pollution standards than those recommended by the Central Council;; his actions remain without precedent as in almost all cases the Environment Agency has consistently adopted the Council's recommendations. $^{60}$ Ōishi's dedication and passion to combating Japan's environment problems were an expression of passion and an ethical attitude towards environmental issues. It is not an exaggeration to say that without Ōishi's love of nature, and his principled consideration of the Japanese environment, that the newly established Environment Agency would have been largely pressured and controlled by the more powerful ministries and agencies.

Finally, with the establishment of the MOEN in 2001, greater strength was given to policy making; the Ministry continued with the responsibilities and visions previously dealt with by the Agency. The Agency had dealt with domestic air and water pollution whilst the MOEN used past experiences to broaden the vision of combating global environmental problems. In October 2001 the OECD reported on Japan's environmental performance. It stated that the greatest pressure on Japan's environment had its origins in the transport, agriculture, and energy sector; the primary issues were air pollution, waste management, nature conservation, climate change, and global environmental cooperation. ${ }^{61}$

\footnotetext{
58 "Politics at Stockholm: national foot-dragging", Science News, Vol. 101, No. 25, 1972, p. 390.

${ }^{59}$ Y. Suwa, Nihon wa kankyō ni yasashii no ka (Is Japan kind to the environment?), Shinpyō Sha, Tokyo, 1998, p. 214.

* The Central Council is composed of government bodies, and its members consist of academics, scientists, local government representatives, business groups, and others.

${ }^{60}$ Gressor, Fujikura and Morishima, Environmental Law in Japan, p. 241.

${ }^{61}$ OECD Environmental performance review on Japan, conclusions and recommendations, Paris-11 January 2002.
} 
When the Ministry took over the Agency's portfolio in 2001 it placed a strong emphasis on 'the society'. For instance, the MOEN aimed at designing a new sustainable society through three key phrases: 'Wa no kuni (Environmental nation), Wa no kurashi (Environmental living) and Wa no chikyū (Global environment)'. ${ }^{62}$ The most noticeable change within the Ministry was the emphasis that it has shown in the development of policy. The MOEN emphasized that 'partnership' is the mainstay of the policy, a partnership with the Japanese public, companies, local governments and overseas governments. $^{63}$ This approach has certainly improved the openness of the policy and flexibility in its making. The MOEN has taken over the long lasting kōgai law-suits and is the central body to coordinate with other ministries on environmental issues. The MOEN has played, and will continue to play, the role of initiator in Japanese environment policy making.

3.2. The Ministry of International Trade and Industry (1949 - 2000), renamed the Ministry of Economy, Trade and Industry (2001-.)

The MITI and the METI have been important constituents in Japan's environment policy making. Whilst previously the Environment Agency, and presently the MOEN, have been the initiators of environment policy making, the MITI and the METI also contributed and negotiated in the decision making process. The MITI was the responsible bureaucracy to shape Japanese industrial and economic policy in the post-war period; its principle goal was economic growth. Chalmers Johnson mentioned that in 1962 the London Economist published a paper headed Consider Japan in which the country's 'economic miracle' was mentioned for the first time. ${ }^{64}$ It revealed not only the significant role of the MITI in the 'miracle' but also its close relationship with big business. The MITI however was confronted with public outcries when the kōgai issues arose. A noteworthy Kōgai Kokkai was held in 1970 in which fourteen anti-pollution laws were passed; the phrase "in harmony with the economy" which the MITI had wanted to be included in the basic law,

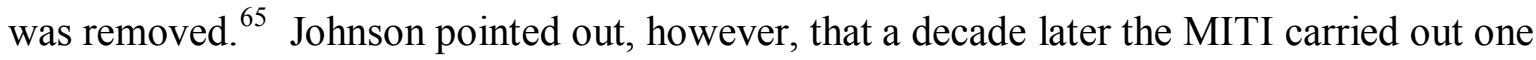

\footnotetext{
${ }^{62}$ Ministry of the Environment, 21 seiki kankyō no seiki wo mukaete ( $21^{\text {st }}$ Century, the century for environment), April 2002, a government brochure, p. 3.

${ }^{63}$ Ibid., p. 3.

${ }^{64}$ C. Johnson, MITI and the Japanese miracle, The Charles E. Tuttle Company, Inc., Tokyo, 1982, p. 3.

${ }^{65}$ Ibid., p. 284.
} 
of the most effective industrial clean up campaigns in its history. ${ }^{66}$ It could be said that even though it was the MITI's responsibility, the Ministry managed to minimize the pollution clean up costs and that this made for a tighter relationship with the nation's big businesses: this was in order to achieve harmony with economic growth.

There are three features of the MITI/METI's involvement in Japan's environment policy development. Firstly, MITI had a reasonable degree of control over the Environment Agency as when it was established officials from the MITI were appointed to key posts within the Agency. These posts included the areas of accounting, planning, and the coordination section of the Agency. ${ }^{67}$ This allowed MITI the opportunity to sway environment policy to protect its bureaucratic interests, rather than solely to consider the best interests of the environment.

Secondly, the MITI/METI was the negotiator between the Environment Agency, the MOE, and Japanese industry. Its primary role was to foster economic development and to support Japanese industry to reach its economic goals. The MITI/METI also aided and supported Japanese businesses with regulations relating to environmental issues. The MITI/METI was apt to be less stringent in its interpretation of regulations and showed leniency towards manufacturing companies. T. Hatakeyama, T. Ōtsuka, and Y. Kitamura, pointed out that the government bureaucracy supported the practice of company self regulation with respect to environmental issues as it could save money for the bureaucracies and for companies. ${ }^{68}$ According to information on laws and regulations from the MOEN, the MITI and the METI have since 1971 given 78 recommendations, instructions, and regulations through the Environmental policy but have not passed a single law; about a half of the instructions applied to waste and recycling. ${ }^{69}$ Japan's recycling laws are strict and successful due to the participation of the central and local governments, companies, and the public. However, it is the consumer who pays most of the cost of recycling, particularly for household appliances. From April 2001 householders were charged around $\$ 25$ to discard washing machines and television sets, and around $\$ 50$ for

\footnotetext{
${ }^{66}$ Johnson, MITI and the Japanese miracle, p. 284.

${ }^{67}$ J. Gressor, K. Fujikura and A. Morishima, Environmental Law in Japan, p. 237.

${ }^{68}$ T. Hatakeyama, T. Ötsuka and Y. Kitamura, Kankyō Nyūmon (Introduction to Environmental Law), Nihon Keizai Shimbun sha, Tokyo, 2003, pp.198-199.

${ }^{69}$ Ministry of the Environment, available at: http://www.env.go.jp/hourei/, (accessed 9 December 2007).
} 
refrigerators. $^{70}$ The responsibility has been put on consumers and not on the companies that produce the appliances.

Finally, the MITI / METI has responsibility for industry; its jurisdiction covers the establishment of standards for pollution control in factories and includes air pollution, effluent water quality, noise levels, and the disposal of industrial and non-industrial waste. $^{71}$ As the MITI was able to retain control over the Japanese industrial and economic policy, so too was it able to design the domestic environment policy to accommodate business and industry. From a legal perspective, Frank Upham said that the MITI was able to shape policy by having private consultations with industry associations and individual firms. ${ }^{72}$ Upham also noted that the Japanese legal system functions on the basis of harmony, consensus, and compromise, rather than on rights and duties. ${ }^{73}$ It could be said that, particularly with environmental issues, the rights and duties towards protecting human health and the preservation of the living environment are imperatives that industry should carry out.

\subsection{Nippon Keidanren (Japan Business Federation)}

The third player is Japan's Business Federation. Nippon Keidanren (hereafter Keidanren) is Japan's largest, single economic and business federation; it spurs on the country's economic growth and looks after corporate interests. According to the Keidanren records as of June 2007 , there are 1,662 members of which 1,343 are companies, 130 are individual associations, and 47 are regional economic organizations. ${ }^{74}$ It can be understood from the membership details how the federation is able to influence not only socio economic decisions, but also political decisions. The Keidanren was established in 1946 and without it the post war economic success would not have been so successful. However, that success has come at great cost as it has caused irreparable damage to the environment and to human lives. The Keidanren was closely tied to the MITI/METI and it influenced the development of the environment policy. There were three factors that had

\footnotetext{
${ }^{70}$ M. Corliss, "Recycling law lets producers off hook, taxes consumers: critics", The Japan Times, 21 March, 2001, available at: http://search.japantimes.co.jp/cgi-bin/nn20010321b1.html, (accessed 28 December 2007)

${ }^{71}$ Gressor, Fujikura and Morishima, Environmental Law in Japan,pp. 237 - 238.

${ }^{72}$ Upham, Law and social change in postwar Japan, Harvard University Press, Cambridge, 1987, p. 24.

${ }^{73}$ Ibid., p. 209.

${ }^{74}$ Nippon Keidanren, http://www.keidanren.or.jp/english/profile/pro001.html, (accessed 7 December 2007).
} 
direct and indirect impacts on the government policy. Firstly, since the beginning of the 1990s Japanese industries have become more like the regulators than the regulated. Before that time it was still difficult for industry to comply with government requirements, but in 1991 the Keidanren took a positive step towards the preservation of the environment by emphasizing the importance of not only handling environmental damage but preventing it. For instance, the 'Keidanren Global Environment Charter' in 1991 attempted to guide industries and companies towards environmental preservation. Junichirō Koga pointed out that the Charter urged industry to adopt voluntary environmental guidelines before the government set regulations. ${ }^{75}$ According to Ken'ichi Imai, even after the Japanese economy had recovered, the government continued to control industrial materials and to maintain industrial policy towards individual industries; this was enforced by the bureaucracy under the guise of administrative guidance. ${ }^{76}$ It illustrates the close relationship between industry and government ministries.

Secondly, as Japanese industry has been self-regulating in the control of pollution emissions, it has led to a close collaboration with the MITI. Because of the strong connections between big business and the MITI, Japanese manufacturing industries could have influenced the drafting of the 1967 BLEPC. Upham pointed out that the Keidanren, the MITI, and other allies, have been successful in removing the strict liability in pollution disputes and with administrating compensation for pollution victims. ${ }^{77}$ The Keidanren may well have far more indirect control in this area than is realised. The Keidanren's annual policy assessment on both the LDP and the Democratic Party of Japan (DPJ) indicate that the Keidanren appears to be a shadow policy maker with regard to environmental issues. Since 2004 the Keidanren has ranked the major political parties judged on how they have reflected its views. For instance, the 2007 Keidanren Policy Assessment rating of political parties for their environmental policy actions on a scale downwards from A to E showed that it rated the LDP as 'B', and the DPJ as 'D'. ${ }^{78}$ In 2006 , the Japan Times reported that since 2004 the Keidanren has made an annual evaluation of the policies of the major political parties, and of donations made by companies and

\footnotetext{
${ }^{75}$ J. Koga, Keidanren, Nihon wo ugokasu zaikai shinkutanku (Keidanren, business circle think-tank that influences Japan), Shinchō sensho, Tokyo, 2000, p. 213.

${ }^{76}$ K. Imai, "Japan's industrial organization", in K. Sato (ed.), Industry and business in Japan, M. E. Sharpe Inc., New York, 1980, p. 77.

${ }^{77}$ Upham, Law and social change in postwar Japan, p. 58.

${ }^{78}$ Keidanren no seisaku hyōka ni tsuite (Regarding Keidanren's policy assessment), November 2007 , http://www.keidanren.or.jp/japanese/policy/2007/087.html, (accessed 9 December 2007).
} 
industries; donations in 2005 amounted to 2.5 billion yen, a 40 percent increase from the previous year. ${ }^{79}$

Finally, Japanese industries now see themselves as active participants in environmental politics. The Keidanren especially has shown a very positive commitment to a technological involvement in order to solve domestic and global environmental problems. The spur for this might well have been the four major kōgai legal battles during 1960s. The 1972 Environment White Paper revealed that the four companies shared about 50 percent of the total of 15.5 trillion yen for the social cost (tentative) of environmental pollution in $1970 .^{80}$ Environmental pollution decreased during the 1970 s but this was due in part to a slowing down of the industrial output resulting from the 1973 and 1979 oil shocks. In the 1980 s hopes grew for a solution to environmental problems by the use of technology. At that time the Japanese government established the New Energy and Industrial Development Organization; it is the nation's largest public research and development organization for expanding environmental technologies. ${ }^{81}$ Japanese manufacturing has made the transformation from environmental polluters to green industries, corporations that are now not only concerned about the environment but are also contributors to a sound, healthy environment. The Japanese government believes that science and technology can solve environmental problems; the faith in technological innovation in the environmental field could be seen from the voluntary establishment of the Japan Environmental Technology Association (JETA) in 1979: it is a non profit organization with around 100 member companies and institutions. There are a number of objectives that JETA advocates; they include water and air quality, and improving environmental measuring technology. JETA also contributes to the protection of people's health and the preservation of the living environment through the application of technological expertise. ${ }^{82}$ Some of the members are environmental departments from local governments and there appears to be a network between JETA, the manufacturing industries of the Keidanren, and the government, as their joint aims are harmony between economic growth and environmental protection.

\footnotetext{
${ }^{79}$ Y. Nakamura, "Keidanren lauds Abe's first 40 days in office", Japan Times, 6 November 2006, available at: http://search.japantimes.co.jp/cgi-bin/nb20061106jp.html, (accessed 9 December 2007).

${ }_{80} 1972$ Environment White Paper, http://www.env.go.jp/policy/hakusho/img/147/tbx.1.gif, (accessed 5 December 2007).

${ }^{81}$ New Energy and Industrial Technology Development Organization, http://www.nedo.go.jp/introduing/about.html, (accessed 10 April 2007).

${ }_{82}$ Japan Environmental Technology Association, http://www.jeta.or.jp/outline/outline 02.html, (accessed 10 December 2007).
} 
This harmonious relationship allowed Keidanren greater flexibility. Since the introduction of pollution control measures, Japan's industries have collaborated with the government and this has allowed them to be active players, rather than to be just the regulated ones. By 1989 Japan had 2,189 plants operating for desulphurisation and denitrification; this was more than six times the number in the United States and represented three-quarters of the total installed world wide. ${ }^{83}$ Science and technology have made great contributions towards solving environmental problems, but they have also been the cause of many of them. Ui also believes that it is a mistake to believe, as do many administrators within government, that science and technology can provide all the answers. The environment is far too complicated for that simplistic notion. ${ }^{84}$

\section{Japan's domestic environment policy approach}

By the $21^{\text {st }}$ century Japan had transformed itself from the world's most polluted industrial nation into one of the world's most environmentally conscious one. The Japanese environment policy evolved through the effect of the industrial development from 1945 to the early 1970s, and the urban development from the early 1970s until the late 1980s. These expansions provided a stimulus to shape a policy that would control and preserve the quality of Japan's natural world. Today the country aims to be not only an economic superpower, but also an 'environmental' superpower, dedicated to clean environmental amenities within the society. Japan's domestic environment policy approach has three objectives.

\subsection{Sustainable society - 国民運動 (Kokumin undō: National movement)}

The stated aim of Japan's domestic environment policy is to build a sustainable society; since the late 1980s the notion of 'sustainability' has been the philosophy behind the policy. In 1987 the World Commission on Environment and Development alerted the world to the importance of the sustainability of the environment, and of the sustainability of development. Japan's annual Environmental White Paper first mentioned the term

\footnotetext{
${ }^{83}$ A. Goghlan, "The green empire”, The New Scientist, vol. 140, no. 1893, 2 October 1993, p. 49.

${ }^{84} \mathrm{Ui}$, "Conclusions", in J. Ui (ed.), Industrial pollution in Japan, p. 178.
} 
sustainability in its 1992 publication. It began by saying that Japan has been urged to develop an economically sustainable society, ${ }^{85}$ and that this would become the pillar of Japan's environment policy. Since 2001 the MOEN has published an additional White Paper dealing with the 'Sustainable Society'. Japan's environment policy closely accommodates the country's industrial strategy; its economic activities are little affected. Japanese industry has benefited from two aspects of the domestic environment policy, recycling and technology development.

Firstly, Japan's recycling program plays an important role in policy direction in that it gives an impression of a sustainable and environmentally conscious nation. Recycling is not only just an action for individuals but is also an action for industry, and this participation results in a positive attitude. Eiji Hosoda, Dean of Keio University Tokyo, stated that as Japan has the technology, it has an important role to play in building a recycling society in Asia. ${ }^{86}$ Particularly since the late 1990 s, numerous recycling laws and regulations have been made by the MOEN, the METI, and other government bodies. For example, the Agency of Environment enacted a law named the Home Appliance Recycling Law (HARL) in 1998 which it put into effect in 2001. The HARL applies mainly to four electric appliances, viz. air conditioners, television sets, refrigerators and washing machines. It imposes a recycling fee on consumers of between $¥ 2,400$ and $¥ 4,600$. $^{87}$ Manufacturers are not obliged to pay any of these fees but the HARL does oblige manufacturers and retailers to meet a recycling target rate of 50-60 percent. ${ }^{88}$ The MOEN alone has more than ten laws governing waste and recycling; these laws are closely attached to the industrial policy. The environment policy has a soft approach to Japan's appliance manufacturers but a hard stance on consumers; this is a typical policy approach. As Miranda Schreurs points out, the 'polluter pays principle' is strongly entrenched in Japan. $^{89}$

The second action is environmental technology development. The Japanese government believes and hopes that the use of technology will reduce environmental pollution, and that

\footnotetext{
851992 Environment White Paper, available at http://www.env.go.jp/policy/hakusyo/hakusyo.php3?kid=204, (accessed 21 October 2008).

${ }^{86}$ M. Namba, “Japan's recycling program”, Asia Pacific Perspectives, vol. 1, no.4, August 2003, p. 23.

${ }^{87}$ Law for the recycling of specified items of home appliances (Home Appliance Recycling Law), Ministry of Environment, available at: http://www.env.go.jp/en/laws/recycle/08.pdf, (accessed 22 October 2008). ${ }^{88}$ Ibid.

${ }^{89}$ M. Schreurs, Environmental politics in Japan, Germany and the United States, Cambridge University Press, Cambridge, 2002, p. 241.
} 
the key to achieving it is to adapt it into the nation's business and industry; these in turn will be willing to contribute their expertise to the undertaking. Japanese companies also receive benefits from the government technological initiatives as they can transform themselves from industrial polluters to environmentally friendly companies. Many corporations such as Panasonic and Toyota are increasing market opportunities by producing goods that are able to bear the so called 'Eco Stamp' (Environmental Approval). ${ }^{90}$ They attempt to portray an image of caring for the environment by using technology to produce more efficient products. However, Scott Cavanaugh argues that the cost saving can often be negligible; the Energy Saving Trust reported that the average costs saved on ‘eco-friendly’ washing machines can add up to only $¥ 1,600$ per year. ${ }^{91}$ The Japan Automobile Manufacturers Association Inc. stated that Japanese automobile manufacturers have endeavoured to develop technology to decrease motor vehicle emissions that contribute to global warming. Japanese environmental technologies are world leaders in the fields of fuel efficient cars, solar energy panels, and nuclear power plants. In 2007, approximately 4 million cars were manufactured in Japan of which 80 percent achieved a reduction of 75 percent of the 2005 standard emission gas levels. ${ }^{92}$

Japan's technological innovations purport to make possible a sustainable society; however, the eco-friendly innovations seem aimed more at business success rather than at environmental management success. Environmental technology solutions have overlapped into economic policy solutions by which business hopes to achieve maximum productivity. Many Japanese businesses are aware that the means to success now is not only just through hard work, but also by working for and with the natural world.

\subsection{Global environmental focus}

Since the late 1980s in particular, Japan's environment policy has focused on world issues and the Government has aspired to become a leader on the global environmental stage. In the mid-1980s global environmental concerns were hot issues, for the most part among the

\footnotetext{
${ }^{90}$ S. Cavanaugh, "Seeing the light", Japan Inc. , no. 80, 31 August 2008, http://www.japaninc.com/mgz september 2008 japanese-companies-changing-the-earth, (accessed 22 October 2008).

${ }^{91}$ Cavanaugh, "Seeing the light", Japan Inc.

92 Japan Automobile Manufacturerrs Association, Inc., 2007 Nendo teikōgaishatō no shukka daisū jisseki no $k \bar{h} h y \bar{o}$ ni tsuite (Regarding a report on the 2007's low environmental pollution car shipment), 20 October 2008, http://release.jama.or.jp/sys/news/detail.pl?item id=1346, (accessed 23 October 2008).
} 
developed nations, and the Japanese government hoped to take the leading role. The 1989 Environment White Paper stated that Japan was a 'Sekai ni kōken suru kokka (Country that contributes to the world)' that would confidently tackle global environmental problems such as climate change, and ozone depletion. ${ }^{93}$ Around the late 1980s the Japanese government, as well as Japanese businesses, were fully aware that focusing on global environmental issues was not only important for environmental preservation, but also for the preservation of Japan's industry in the 'Sekai ni kōken suru kokka'.

There are two reasons why the emphasis on environmental issues has moved from a domestic focus to a global one. The first is that Japan's environmental policy thinking has moved from a focus on human health concerns to a focus on concerns for the natural world; this change occurred around 1990. Tsuru said that in the 1970s there was a shift from the use of the word koggai to the use of the word kankyo (environment) ${ }^{94}$ the term kankyo at that time implied being amenable to the local environment. The Japanese environment policy was a product of three national development periods, the industrial development soon after World War II, the urban development from the 1970s through to the 1980s, and the period of 'sustainable' development from around 1990.

\subsection{Technological solutions}

The Japanese environment policy has firmly endorsed and adapted to the notion that technology can solve environmental problems and in this the Government believes that technological intervention is the key, a stance that has not much changed over the last three decades. The 1977 Environment White Paper emphasized the importance of technology to prevent environment problems. ${ }^{95}$ Thirty years later, the 2007 Environment White Paper not only emphasized that point, but also the point that the wellbeing of the environment was dependent on technological contributions. There is no question that technology is an important tool in solving environmental problems; however, the belief that technology alone can achieve success is very much rooted in industrial and economic philosophy.

\footnotetext{
931989 Environment White Paper, http://www.env.go.jp/policy/hakusho/hakusho.php3?kid=201, (accessed 17 October 2008).

${ }^{94}$ Tsuru, The political economy of the environment, the case of Japan, p. 129.

951977 Environment White Paper, http://www.env.go.jp/hakusho/hakusho.php3?kid=152, (accessed 30 October 2008).
} 
This section looks at the rationale behind the development of the Japanese environment policy.

The Japanese government's vision is given in its 2007 Environment White Paper where it emphasized the development and introduction of technology for the preservation of the environment. It also stated that improved technology would strengthen international competitiveness, the prosperity of new industry, and the betterment of living amenities. ${ }^{96}$ The government believed that Japan had overcome environmental problems through technological innovation. The 2008 Environment White Paper also stressed that to overcome the problems of air pollution from factories and automobiles, technological devices would need further improvement and it must be said that the quality of Japan's living environment has certainly improved over recent decades. The 2002 OECD report on Japan's Environment Performance Review reported that Japan continued to improve its urban air quality in the 1990s, and that Japan ranked third lowest on emission intensity for sulphur oxides and nitrogen oxide. ${ }^{97}$ Japan's environment policy states that technology can not only solve environment problems, but can also show Japan the way to become a 'Green' nation.

In order to achieve a 'Green Japan', the government needs to collaborate with business. The engineering technology of Japanese industry allows it to participate in the environment policy making process. The policy helps industry to develop business opportunities and in turn the policy benefits from industry expertise. Official sources, such as the Japanese environment policy and the OECD, have acknowledged the significant growth of Japan's environment related businesses. According to a media report from the Ministry of Environment in May 2003, Japan’s environment business in 2000 was $¥ 2.9$ trillion; it is expected to grow to $¥ 47.2$ trillion by 2010 , and to $¥ 58.4$ trillion by 2020 . $^{98}$ The employment level in 2000 was about 7.7 million and the numbers are expected to increase to 11.2 million by 2010 and to 12.4 million by $2020 .{ }^{99}$ The means for Japanese business to

\footnotetext{
${ }^{96} 2007$ Environment White Paper, http://www.env.go.jp/policy/hakusho/h19/index.html, (accessed 3 November 2008).

${ }^{97}$ Organization for Economic Co-operation and Development, Environmental performance reviews on Japan, conclusions and recommendations, 11 January 2002, Paris, p. 4.

${ }_{98}$ Ministry of Environment, media report, 'Wagakuni no kankyō biginesu no shijō kibo oyobi koyō kibo no genjyō to shōrai yosoku nit suiteno suikei nit suite (About the current and future in Market and employment scales of Japan's environment businesses)' 29 May 2003, http://www.env.go.jp/press/press.php?serial=4132, (accessed 6 November 2008).

${ }^{99}$ Ibid.
} 
grow is through it having a close integration with the environment policy and to demonstrate technological innovation. In the early 1990s the OECD reported that the global environmental industry was estimated to be around US\$250 billion; the Japanese market share was estimated in 1994 to be around US\$30 billion, the second largest in the world. ${ }^{100}$ Growth rate is expected to be about 5 percent a year. Moreover, the OECD's detailed estimates of growth areas in the Japanese environment industry cover "antipollution equipment, waste management and recycling, waste-water and effluent equipment, new energy sources and energy efficiency; they do not include clean technologies in productive process and environmental R\&D activities"; they will grow from US\$15.2 billion in 1993 to US\$23.3 billion in 2000, and to US\$35.4 billion in 2010. ${ }^{101}$ A recent report by the METI has shown that Japan's industries in the environment field have been growing; in March 2008 the Minister for the METI, Akira Amari, promised to help grow the Japanese environmental industrial market from $¥ 59$ trillion in 2005 to $¥ 83$ trillion by $2015 .^{102}$

Although Japan has established a sound foundation for its environment related businesses, the technology appears to focus narrowly on 'clean' technology, such as clean air and clean water. In 2002 the OECD recommended that Japan should make greater use of economic instruments (e.g. taxes and charges) in its environment policy in order to make it more economically efficient and environmentally effective, and thus to achieve sustainable production and consumption. ${ }^{103}$ The MOEN has attempted to introduce an environment tax to fund the protection of the ecosystem. A carbon tax is one method to penalise the use of fossil fuels such as coal, natural gas, and crude oil which contribute to global warming. Japanese businesses and industries have not welcomed that approach. The Keidanren has adamantly opposed any economic instrument in the environment policy as recommended by the OECD. As mentioned earlier, the 1991 'Keidanren Global Environment Charter' stated that Japanese industry would oppose such an economic instrument. It has become apparent that the Japanese government has allowed the nation's business groups to participate in environmental responsibility through a voluntary contribution of technology,

${ }^{100}$ OECD, "The environmental goods and services industry", http://www.oecd.org/dataoecd/11/10/2090577.pdf, (accessed 7 November 2008). $\frac{1}{101}$ Ibid.

${ }^{102}$ Chūō Nippō, "Nihon kankyō sangyō no taema nai shinka (Japan's environmental industry will grow)", 5 March 2008, http://japanese.joins.com/article/article.php?aid=96951\&servcode=A00\&sectcode=A00, (accessed 24 February 2009).

${ }_{103}$ Organization for Economic Co-operation and Development, Environmental performance reviews on Japan, conclusions and recommendations, p. 3. 
rather than through legislation; these voluntary contributions have given a great incentive for the companies to improve technologies further. However, a considerable part of Japan's technological contribution to the environment tends to focus very much on the reduction of carbon dioxide emissions. Ui questioned whether scientific technologies were the appropriate solution to employ in developing an environment policy; he argued that although the government believes that the introduction of scientific technologies was the most effective way to achieve modernization, and that that may be correct, it was also the way in which intensified environmental destruction was produced. ${ }^{104}$

\section{Kōkyō Jigy (公共事業: Public works)}

Whilst the koggai caused irretrievable damage to the health of both the Japanese people and of their environment, Kōkyō Jigyō (公共事業; literal translation Public Works) has also caused a significant amount of domestic environmental damage and has had an adverse effect on the livelihood of residents living near those projects. This section deals briefly with Japan's public works projects, firstly to discuss what they are, and secondly to look at an example of how a public works project created immense harm, the example used being the Isahaya Bay project in Nagasaki.

Firstly, Japan's major public works started soon after the war but were concentrated more in the early 1970s when Japan elected a new prime minister. Kakuei Tanaka took over from Eisaku Satoh (1964 - July 1972) and whilst Satoh placed an emphasis on koggai, the environment and peace (he signed three Non-Nuclear Principles in 1968), Tanaka was keen on public works projects. When he became prime minister he declared a Nippon rettō kaizō ron (Japanese archipelago reconstruction plan) as one of his policies. Japan's modern major public works started from that time and became the focal point of Japanese politics; Tanaka stressed the importance of public works in order to revitalize the regional economy and consequently improve the national economy.

Firstly, Japan's public works projects are usually infrastructure related projects such as roads, highways, railways, bridges, marine harbours, and dams; Japan has become known

${ }^{104} \mathrm{Ui}$, “Overview”, in J. Ui (ed.), Industrial pollution in Japan, p. 3. 
as Doken Kokka (土建国家: the construction state). Gavan McCormack argued that doken $k o k k a$ are works "in which construction is incidental to the reproduction of power and the distribution of profit". ${ }^{105} \mathrm{He}$ added that when concrete is poured in a construction project, what is being poured are funds being transferred from the public purse into either private or political party coffers. ${ }^{106}$ The Japanese government places great emphasis on the development aspect of the project, but little consideration is given to its harmful effects on the environment. Jain made reference to the fact that some of the projects have the potential to cause great anxiety among the local residents who have enjoyed living in their previous natural environment. ${ }^{107}$ Many of the projects conducted in Japan were initiated by the ruling LDP as the party's survival depended on the continuance of these public works. The Japanese journalist Yuzō Suwa, pointed out that public works are the lifeline of LDP politicians and to secure their seats they guarantee public works projects in their electorates and pay 'On (indebted obligation)' to the construction companies; as a result many elected members are beholden to those companies. ${ }^{108}$ Some of the public works projects do indeed create employment and bring benefits to the regional economy, but the benefits would seem to be unequal; what are often overlooked or ignored are the environmental consequences. Public works projects are often summed up by the phrase, "Once a public works starts, it never stops": this phrase is often voiced by angry local residents. ${ }^{109}$ McCormack argued that although the problem of doken kokka is without doubt political, it has a moral and philosophical aspect as well. ${ }^{110}$ In response to this, some regional governments have shown resistance to projects and have requested the central government to reconsider them in the light of their potential impact on the regional societies. Suwa pointed out that about forty four local governments, particularly those that had suffered kōgai and air pollution, made environmental assessments and presented proposals to the national government to enact a law. ${ }^{111}$ However, there was strong opposition from the MITI and from Japanese businesses which simply stated that “Asesumento hō ga keizai seichō no ashi wo hipparu (an assessment law will slow down economic growth)". 112 Japan's business conglomerates are powerful players who can sway

\footnotetext{
${ }^{105}$ G. McCormack, The emptiness of Japanese affluence, Allen \& Unwin, NSW, 1996, p. 33.

106 Ibid., p. 34.

${ }^{107} \mathrm{Ui}$, “Overview", in J. Ui (ed.), Industrial pollution in Japan, p. 569.

${ }^{108}$ Suwa, Nihon wa kankyō ni yasashii no ka (Is Japan kind to the environment?), p. 214.

${ }^{109}$ M. Kunishima and M. Miura, "The fishery damage by national Isahaya Bay reclamation work", available at: http://shippai.jst.go.jp/en/Detail?fn=2\&id=CD1000139, (accessed 27 November 2007).

110 McCormack, The emptiness of Japanese affluence, p. 25.

${ }^{111}$ Suwa, Nihon wa kankyō ni yasashii no ka (Is Japan kind to the environment?), p. 157.

112 Ibid., p. 156.
} 
the Japanese domestic environment policy; there has been a long battle between industry that seeks business opportunities and those people who value the regional environments. Even though the EIAL was finally implemented in 1999, how effective the Agency will be to properly assess the effects of projects to the natural environment remains a question. Suwa believes that the Environment Agency does not have genuine administrative power as it can only act in an advisory capacity. ${ }^{113}$ The role does not seem to have changed in spite of the fact that the Agency was elevated into the Ministry of Environment.

Secondly, although the public works projects might have helped some regional economies, the project at the Isahaya Bay has caused tremendous direct and indirect ecological damage; the bay is located in Nagasaki prefecture and is one of the largest facing the Ariake Sea located in the South Western part of Japan. The central government sponsored a land reclamation project to establish around 700 hectares of farmland and to prevent tidal flooding by building a levee across the mouth of the bay; the project that was begun in 1986 demonstrates a created, modern environmental disaster. One characteristic of this project that makes it different from other kogai is that the environmental catastrophe was not caused by a straight out industrial development, but was brought about by a government sponsored, public works project. The Isahaya Bay project has raised many contentious issues ranging from the economic viability of farming communities to ecological devastation.

The environmental significance of Isahaya Bay is that it had a coastal wetland rich in both Japanese nori (seaweed) and migratory birds such as mudskippers; the Ariake Sea used to provide about 40 percent of Japan's total seaweed harvest, but the project has seriously undermined that production. The public works project was first initiated in 1952 after the central government received a request from the Nagasaki prefectural government to create 1,000 hectares of paddy fields. Several decades later in 1987 the MAFF finally approved the project on the grounds that it would prevent natural disasters, and would create farmland. ${ }^{114}$ Contrary to MAFF's predictions, there have been far more damaging results than positive outcomes resulting from the scheme. One promised benefit that it would prevent tidal flooding has not happened as floods in the area have not decreased; on the

\footnotetext{
${ }^{113}$ Suwa, Nihon wa kankyō ni yasashii no ka (Is Japan kind to the environment?), p. 244.

114 Ibid., p. 244.
} 
contrary, new types of inundation disasters have occurred. ${ }^{115}$ Fishing productivity has declined and the amount of seaweed harvested in the Bay area has similarly fallen. It is extremely difficult to find any positive outcomes from the project that was completed in 2007.

Japan's public works projects not only affect the rural environment and agricultural industry, but they also create enormous debts. The obsession of the LDP government with public works construction has given Japan the title of Doken Kokka (the Construction State). Takayoshi Igarashi pointed out that public debt is so high that the central government is forced to allocate 40 percent of its annual general budget to loan repayments, whilst for local governments the figure is 20 percent. ${ }^{116}$ According to the Ministry of Finance, public works projects in 2006 cost $\$ 72$ billion, and in 2007 it was around $\$ 70$ billion; ${ }^{117}$ this is approximately one sixth of Japan's total annual expenditure. Purnendra Jain stated that "public works projects bring employment and commercial advantages to the community - the pork of pork barrel politics - so that local representatives in the national Parliament usually receive kudos from local supporters when they bring home public works projects". ${ }^{118}$ Some public works projects may bring some benefits to selected interests, but how much benefit from those projects filters down to the grassroots community remains an unanswered question.

As mentioned earlier, McCormack believes that there are moral and philosophical issues in Japanese construction work projects; this also applies to public works projects. A good example of where few benefits from the public purse flow to the general public but rather to Japan's kōeki hōjin (公益法人: public interest corporations) and other vested interested groups, is Japan's scientific research whaling program (discussed in chapter four). Eiichi Shibusawa espoused the business code that profits should be returned for the benefit of the public (discussed in next chapter), but today's public works do not reflect his philosophical teachings, the principles of which had been deeply embedded in traditional Japanese cultural and moral values.

\footnotetext{
${ }^{115}$ Kunishima and Miura, "The fishery damage by national Isahaya Bay reclamation work"

${ }^{116}$ T. Igarashi, "Public works at a crossroads", Social Science Japan, no. 17, December 1999, p. 3.

${ }^{117}$ Ministry of Finance, Japan, http://www.mof.go.jp/jouhou/syukei/h19/h180908.htm, (accessed 20 December 2007).

${ }^{118}$ P. Jain, "Jumin Tohyō and the Tokushima anti-dam movement in Japan, the people have spoken", Asian Survey, vol. 40, no. 4, 2000, p. 551.
} 


\section{Conclusion}

Japan's domestic environment policy was established in order to counter the nation's worst koggai and was developed through the passing of laws and regulations. In 1971 the establishment of Japan's Environmental Agency was a highly significant event; the Japanese public believed that it promised much towards solving the nation's pollution problems. These problems had been caused by unprincipled industrial activity and an 'economic development at all costs' mentality by the central government. The Japanese government set stringent guidelines in order to control the nation's industrial pollution; however, the environment policy continues to place a strong focus on science and technology when searching for these solutions. There is a division of roles among the three players who influence and shape the domestic environment policy with the Keidanren particularly accommodating to the policy through self-regulation in order to maintain a powerful voice over policy direction. Japan's domestic environment policy caters to issues that range from industrial and urban pollution to public works projects.

One key feature of Japan's environment policy is that it is accommodating towards Japan's economic policy. The economic policy has a strong influence over the environment policy, especially in regard to environmental regulations. In the beginning the policy approached the domestic problems by using the Japanese essence of environmental ethics (mentioned in Chapter 1). However, the principles incorporated into the policy by Buichi Ōish have now been diluted. Today, Japan's domestic and global environment policies actively cater to global environmental initiatives, with the strong belief that technology can solve the problems and improve the future. Although Japan's global environmental policy, which followed the domestic one, attempts to project the image of an environmentally friendly nation, its principle aim is to maintain sustainable economic development as well as sustainable environmental development. 


\section{CHAPTER THREE}

\section{JAPAN'S GLOBAL ENVIRONMENT 'POLICY'}

Japan has benefited greatly from its use of an enormous amount of global natural resources and this has allowed the country today to become the world's second largest economy. As a consequence of Japan's tremendous demand for natural resouces, the sustainability of supply of some of these overseas supplies has been put at risk, as has the integrity of the natural world from where they have been extracted. Japan itself is singularly lacking in natural resources with the result that it has become increasingly dependent on foreign supplies; along with that reliance has come a diminishing self sufficiency in many of its food commodities. A good example is seafood: Japan is one of the world's largest consumers and according to the Ministry of Agriculture, Forestry and Fisheries (MAFF), its self-sufficiency rate of 86 percent in 1965 had dropped to 66 percent by 2007. ${ }^{1}$ On just this one item, it illustrates Japan's dependency on, and inseparable relationship with, the rest of the world for supplies. With Japan's industrial activities a similar situation exists; to maintain its economy, in the energy sector alone the country needs to import vast amounts of coal, natural gas and crude oil, along with uranium. With the benefits that Japan receives from using global resources, there comes the responsibility for the environmental degradation that this consumption brings about.

This chapter assesses Japan's global environment policy (GEP) to see whether it incorporates ethical considerations of the wellbeing of the global environment. The chapter also argues that although the Japanese government has played a prominent role in global environmental issues, the sincerity of its intentions in policies that impact on the overseas environment has often been called into question. The government promotes an image by aligning itself with projects that combat environmental degradation, but all too often the hand of Japanese business and commercial interests are evident. Japan believes that it has the capability to solve global environmental problems using its expertise in

\footnotetext{
${ }^{1}$ Ministry of Agriculture, Forestry and Fisheries, Shokuryō jikyū ritsu (Food self-sufficiency rate), http://www.maff.go.jp/j/tokei/sihyo/data/02.html, (accessed 23 March 2009).
} 
environmental science and technology, but many contemporary scholars in the fields of philosophy, politics, international relations, and economics have expressed the view that a philosophical input is also needed in order to contribute to a judicious environmental policy.

The chapter comprises three parts; the first seeks to explore the policy development, the second part examines the interest groups behind the Japanese GEP who are influential in shaping its direction, and the final part analyses Japan's GEP approaches. There are three important strategies that the Japanese government applies; collaboration with Japan's big businesses, allocation of Official Development Assistance (ODA), and the promotion of environmental 'green technology'. Business, ODA, and technology are the three core components of Japan's GEP. The policy places a high value on the notion that technology can solve environmental ills, but it fails to recognise the importance elements of sustainability, biodiversity, equitable sharing of resource capitalization, and fairness to people whose natural environment has been compromised. Both Western and Japanese environmental ethics emphasize the importance of the relationship with nature. The Japanese particularly value the concept of living harmoniously with nature, derived from its religious and cultural heritage. The Japanese believe in a humble attitude towards nature, to assimilate with it rather than to fight against it; this is the essence of the Japanese environmental concept (discussed in Chapter one).

\section{Japan's global environmental policy development}

Japan's global initiatives began in the early 1980s. The backdrop was the establishment of the World Commission for Environment and Development (WCED) in which Japan showed great interest. Shigeyuki Okajima pointed out that it was Bunbei Hara, the Director General of the Environment Agency (November 1981-November 1982) who persuaded the Japanese Prime Minister Zenkō Suzuki to commit ¥1 billion to the commission; he proposed its establishment at the Nairobi Conference of the United Nations General Assembly. ${ }^{2}$ The Japanese government, especially the Environment Agency, realized the importance of handling environmental issues at the top level.

\footnotetext{
${ }^{2}$ H. Ishi, S. Okajima and T. Hara, Tettei tōron, Chikyu kankyō (Debate on the global environment), Fukutake Shoten, 1992, p. 74.
} 
The Agency announced its intention to contribute to the preservation of the global environment. In the 1988 'White Paper' the government expressed the belief that, as Japan was economically powerful, it had therefore a degree of responsibility for the future of the globe; it was confident that it could contribute to global environmental preservation by using its economic power, technocratic capability and past experiences. ${ }^{3}$ In the following year four actions clearly indicated the government's strong commitment to this issue. It participated in the Vienna Convention, in the Montreal Protocol for the protection of the Ozone Layer, in the setting up of the Council of Ministers of Global Environment Conservation, and for the Director-General of the Environmental Agency to be also the Minister of State in charge of global environmental problems.

The theme of the 1988 White Paper was Sekai ni kōken suru kokka (the country that contributes to the world). The impetus was the document 'Our Common Future' from the WCED in 1987; it is also known as the Bruntland Report and strongly influenced the development of Japan's GEP. As Schreurs pointed out, the publication of 'Our Common Future' was an important turning point at that time as the Environment Agency moved to strengthen its global environmental research and policy-making capacities. ${ }^{4}$ The key concept of the document was: "Development that meets the needs of the present without compromising the ability of future generations to meet their own needs. "5

Japanese business practices abroad, such as drift net fishing and tropical hardwood felling, have given the country a bad image and the government has attempted to change this. Japan's irresponsible overfishing and its rapacious appetite for natural resources caused a great deal of ecological and environmental damage. Professor Hanns Maull pointed out in the late 1980s that Japan was generally seen as one of the worst offenders in regard to the protection of nature and the global environment, through activities such as the smuggling of endangered wildlife species and the destruction of tropical rainforests. ${ }^{6}$ Although the Japanese government made an impressive start in its promise to contribute to combating

\footnotetext{
${ }^{3}$ The 1988 White Paper of the Environment Agency, http://www.env.go.jp/policy/hakusyo/hakusyo.php3?kid=163, (accessed on 3 January 2007).

${ }^{4}$ M. Schreurs, Environmental politics in Japan, Germany, and the United States, Cambridge University Press, Cambridge, 2002, p.162-163

${ }^{5}$ S. Beder, The nature of sustainable development, Scribe Publication Pty, Ltd., Newham, 1993, p. xiii.

${ }^{6}$ H. W. Maull, "Japan's global environmental policies", in A. Hurrell and B. Kingsburry (eds.), The international politics of the environment, Oxford, Clarendon Press, 1992, p. 354.
} 
world environmental problems, it is obvious that the policy was developed with the intention of using the country's economic power. Maull argued that Japan's GEP had evolved along the lines of its domestic policy, a policy developed in response to pressures brought about by environmental problems and then tackled through the application of technology. ${ }^{7}$ In fact Japan's GEP evolved as a blend of its domestic environmental policy and its foreign affairs policy; the nature of its contributions gave the impression of a diplomatic approach. The GEP is one tool in Japan's strategy to ensure that the lifeblood of the nation, the securing and maintaining the supply of overseas resources, continues.

While 'Our Common Future' was the catalyst for the initiation of the Japanese GEP, the government used the slogan 'participation and contribution' and shaped its policy through a sequence of domestic and international developments. Four in particular were significant in influencing policy development.

\subsection{Rio de Janeiro}

The first event was the United Nations Conference on Environment and Development (UNCED) at Rio de Janeiro in June 1992, also known as the 'Earth Summit'. According to the United Nations (UN) that meeting was unprecedented as a conference in terms of the scope of its agenda: 172 countries participated in it and 108 were represented by their heads of State or Government. ${ }^{8}$ The governments at the summit recognized the need to ensure that all economic decisions fully took into account any resultant environmental impact, and the need for environmentally sustainable developments. ${ }^{9}$ The Japanese government was an active participant; it promised to strengthen its environment related ODA and agreed to increase spending over the next 5 years from US\$9 billion to US $\$ 10$ billion. ${ }^{10}$ The Japanese government also signed the Framework Convention on Climate Change, the Biodiversity Treaty in Rio de Janeiro, and reconfirmed its pledge to stabilize

\footnotetext{
${ }^{7}$ Maull, “Japan's global environmental policies”, pp. $365-366$.

${ }^{8}$ The Earth Summit in the United Nations homepage, http://www.un.org/geninfo/bp/enviro.html, (accessed on 4 January).

${ }^{9}$ Ibid.

${ }^{10} 1993$ Environment White Paper, http:/www.env.go.jp/policy/hakusyo/hakusyo.php3?kid=205, (accessed on 5 January 2007).
} 
$\mathrm{CO}_{2}$ emissions at the 1990 level on a per capita basis by the year 2000. (This was not achieved). ${ }^{11}$

By these pledges the Japanese government had attempted to show a positive commitment at the summit, but Prime Minister Kiichi Miyazawa did not attend as he was dealing with domestic peace keeping operations. Although Japan promised to contribute a large sum of ODA, the absence of the prime minister at the meeting showed that a full commitment was lacking. Takeshi Hara noted that it was most regrettable that Miyazawa did not attend for it showed the inability of the Japanese political system to deal with international affairs. ${ }^{12}$

The contribution of money and technology is an important factor in giving assistance, but it is not the 'be-all-and-end-all'. Brendan Barrett and Riki Therivel observed in the early 1990s that the Japanese Environment Agency's approach assumed that only money and technology were needed to solve global environmental problems. In contrast they believed that a more fundamental assessment, one that also includes social aspects, is needed in order to achieve sustainable development. ${ }^{13}$ It could be said that Japan's GEP solutions to environmental concerns were, and continue to be, based on financial solutions. Although Japan's GEP identified itself as a significant contributor in efforts to solve global environmental problems, little has been done to show that the government has delivered on its promise to follow the theme of the 1993 White Paper, that of environmentally sustainable development.

\subsection{Basic Environment Law}

The second event, the establishment of the Basic Environment Law (BEL), not only shaped the direction of Japan's GEP, but further strengthened it. The law was based on the Basic Law for Environmental Pollution Control of 1967 and the Nature Conservation Law of 1972. Due to growing concerns about both domestic and international environmental issues, the government in 1993 enacted the law in an attempt to protect the environment.

\footnotetext{
${ }^{11}$ Schreurs, Environmental politics in Japan, Germany, and the United States, p. 175.

${ }^{12}$ T. Hara, "The history, present situation and challenges of environmental journalism", by the Japanese forum of environmental journalists, 1995, http://www33.ocn.ne.jp/ ifej/index-r.html, (accessed on 5 January 2007).

${ }^{13} \mathrm{~B}$. Barrett and R. Therivel, Environmental policy and impact assessment in Japan, Routledge, London, 1991, p. 86.
} 
What is significant about the BEL is that it set out the basic principles mentioned at the beginning of this chapter; it emphasized sustainable development and the promotion of global environmental conservation through international cooperation. ${ }^{14}$ The BEL also addressed the responsibility of the central and local governments, along with the business and public sectors; it also provided a strong framework for the Japanese GEP to engage in international activities. One positive aspect of the law was that in spite of the collapse of the Japanese bubble economy at that time, the policy showed a genuine commitment to global environmental problems. Another positive aspect was that throughout that decade the Japanese policy developed not only through the agency of the central government, but that it also incorporated initiatives from local governments. Hidefumi Imura has pointed out that since the Earth Summit a number of prefectural and municipal governments began to examine their roles in the protection of the environment. ${ }^{15}$

In the following years many laws and regulations concerning both domestic and global environmental related matters were passed and enacted by the central government. Imura made the point that the strength of Japan's approach was that once environmental goals were set, in many cases but not all those goals could be met because there was a relatively effective structure for both domestic and international policies. ${ }^{16}$ Japan aspired to become a world leader in some area: it could not dominate finance, and a military role was not an option; however it saw an opportunity in the field of environmental protection, a role that dovetailed nicely with its overseas aspirations (discussed later).

\subsection{Kyoto Conference}

The third event was the UN sponsored Kyoto Conference on Climate change (COP3) held at Kyoto in 1997. The Conference gave weight to the Japanese GEP slogan of 'participation and contribution' and also determined the country's position in global environmental issues. Japan's willingness to play an important role in global environmental concerns was clearly enunciated by the government; in front of 2,000

\footnotetext{
14 '21seiki kankyō no seiki wo mukaete (the $21^{\text {st }}$ Century)' by Ministry of the Environment, June 2001, p. 43.

${ }^{15}$ H. Imura, "Japan's environmental policy: past and future” in H. Imura and M. Schreurs (eds.), Environmental policy in Japan, Edward Elgar, Northampton Massachusetts, 2005, p. 44.

${ }^{16}$ H. Imura, "Evaluating Japan's environmental policy performance" in H. Imura and M. Schreurs (eds.), Environmental policy in Japan, p. 342.
} 
delegates Foreign Minister Keizo Obuchi made the statement that "these 10 days could change the history of mankind". ${ }^{17}$ The speech that he delivered publicised the fact that environmental concerns were not only the preserve of the Environment Agency, but also of the Ministry of Foreign Affairs (MOFA). Japan's greater commitment, especially since the Kyoto Conference, was shown by its involvement in several international negotiations. Japan's GEP was certainly shaped in such a way as to present its government as a 'Green Conscious' nation. While the policy was designed and decided at the Environment Agency, the active participation and contribution by the MOFA influenced its shape. In 1988 the MOFA proclaimed, for the first time, that the global environment was a top priority in Japan's foreign affairs policy. ${ }^{18}$

A significant aim of Kyoto was for individual countries to set goals to reduce their greenhouse gas emissions measured against their 1990 emission levels. As remarked by Schreurs, Japan's political leaders and bureaucrats found a way to connect global environmental issues to the country's endeavour to play a larger global role, and at the same time to develop new markets for its expertise and finance. ${ }^{19}$ Following the Kyoto Conference the Japanese GEP was closely linked to its foreign affairs policies. Matsushita pointed out that the Japanese government expected three advantageous effects from hosting COP3; to increase the awareness of the participation and cooperation by Japan, to establish a foundation of global warming measures, and to become a valuable international contributor in environmental areas. ${ }^{20}$ Nevertheless, because of business interests the Japanese GEP turned out to be a multi function policy rather than a policy purely concerned with the preservation of a sustainable environment.

Japan was twice given the 'Fossil Award' by the Climate Action Network (CAN") indicating that Japan was the most backward-minded nation in that field. (the evaluations for this award were based on speeches given by government officials at both the Hague Conference on climate change (COP6) in 2000, and at the Marrakesh Conference (COP7)

\footnotetext{
17 "Environmental diplomacy" analysis of the Kyoto Global Climate Conference, 1997, http://www.pbs.org/newshour/forum/december97/kyoto 12 12.html, (accessed on 28 August 2006).

${ }^{18}$ Ministry of Foreign Affairs, Diplomatic Bluebook of Japan, 1998, http://www.mofa.go.jp/policy/other/bluebook/1998/I-d.html\#2, (accessed on 9 January 2007).

${ }^{19}$ Schreurs, Environmental politics in Japan, Germany, and the United States, p. 252.

${ }^{20}$ K. Matsushita, Kankyō seiji nyūmon (An introduction to environmental politics), Heibon sha, Tokyo, 2000, p. 142 .

${ }^{*}$ CAN is a worldwide network of over 365 Non-Governmental Organizations (NGOs) who work on climate change issues.
} 
in 2001. ${ }^{21}$ These brickbats were most likely given because the Japanese government was not able to promise the implementation of the Kyoto Protocol at either COP6 or COP7. Although the Japanese government hosted the Conference in 1997, it had not fully committed itself to contribute to urgent global environmental problems. Takaaki Ishii argued that the Japanese government insisted at the meetings of COP6 and COP7 on proposals that would soften the penalties in case of non-compliance with the protocol, and that it suggested that some business opportunities would arise from the Kyoto mechanism. 22 The government was trying to gain some support from the Japanese business groups who had been reluctant to accept the Kyoto Protocol.

A brief look at events in the Japanese domestic environment is instructive as they had a strong bearing on the development of the GEP. Although Japan was reluctant to commit to the Kyoto Protocol, the central government did enact two laws aimed at reducing $\mathrm{CO}_{2}$ emissions. In 1998 the Household Electrical Appliances Recycling Law, and a law concerning the promotion of measures to cope with the problems connected to global warming, were passed. This was not only significant for the domestic environmental policy but also in that it showed a commitment to tackling climate change concerns. In Japan the cycle of mass production, consumption, waste, and lifestyle convenience obviously created environmental hazards. The government attempted to exercise some control by promoting the principle of 'polluter pays' to the public. Tadahiro Mitsuhashi believed that the laws were necessary for the Japanese government to be able to achieve its promise made at the Kyoto Conference to achieve a 6 percent reduction in $\mathrm{CO}_{2}$ emissions. $^{23}$

The Japanese government brought the second law to the attention of the central and local governments, business, and the public sector, in order for them to take some responsibility in reducing domestic $\mathrm{CO}_{2}$ emissions. Three Japanese scholars, T. Hatakeyama, T. Otsuka, and Y. Kitamura, were critical of the government's response, arguing that it was bitterly disappointing that the Japanese business groups did not offer a target figure to reduce $\mathrm{CO}_{2}$

\footnotetext{
${ }^{21}$ T. Ishii, Kyoto giteisho wa jitsugen dekiruno ka (Can the Kyoto Protocol be achieved?), Heibon sha, Tokyo, 2004 , p. 65.

${ }^{22}$ Ibid., p. 66.

${ }^{23}$ T. Mitsuhashi, Kankyō keizai nyūmon (Introduction to environmental economics), Nihon keizai shimbun sha, Tokyo, 2002, p. 74.
} 
emissions, and that the government had only asked them to submit business plans. ${ }^{24}$ The Japanese government's optimistic view has not much changed since the establishment of its GEP. The 1998 White Paper stated that Japan needed to make important changes away from a lifestyle strongly oriented towards consumerism, the wasting of resources, and material over-production, if it were to become a sustainable society. ${ }^{25}$

\subsection{Post ratification}

The fourth significant event was the Japanese ratification of the Kyoto Protocol. The upgrading of the Agency to the Ministry of the Environment in 2001 was a positive turning point for the Japanese GEP. The following year the Japanese government ratified the Protocol as it had faced considerable pressure from both internal and external sources: the point being made was how could Japan handle climate change issues without signing? In ratifying the protocol, Japan committed to its promise of a 6 percent reduction in gas emissions over 4 years from 2008. One of the challenges for the Government was how to tackle the problem when those emissions were closely related to Japanese industrial activity and Japanese lifestyle. Japan attended the 2002 Earth Summit on Sustainable Development and Prime Minister Junichiro Koizumi demonstrated his government's commitment to the global environmental problems with the so-called 'Koizumi Kōsō (Koizumi Initiatives)'. He promised to provide US\$2 billion in educational assistance and expressed his determination to contribute the resources of around 5,000 people towards environmental preservation over a period of 5 years. ${ }^{26}$ Japan continued to participate in the international environmental negotiations and Koizumi attempted to develop further the Japanese GEP by using his successful domestic initiatives.

Japan's GEP followed the traditional domestic environmental approach, but it was strongly influenced by protocols used in developing its foreign policy from where ODA is allocated. Maull predicted in the early 1990s that the Japanese government was likely to narrow its

\footnotetext{
${ }^{24}$ T. Hatakeyama, T. Otsuka and Y. Kitamura (eds.), Kankyō hō nyūmon (The introduction to the environmental law), Nihon keizai shimbun sha, Tokyo, 2003, p. 189.

${ }^{25} 1998$ Environment White Paper, http:/www.env.go.jp/policy/hakusyo/hakusyo.php3?kid=210, (accessed on 11 January 2007)

${ }^{26}$ Ministry of Foreign Affairs of Japan (2002), Yohanesu burugu samitto, Koizumi Souri daijin, Naigai kisha kaiken (Opening speech and interviews by the Prime Minister, Junichiro Koizumi at the Johannesburg Summit, 3 September 2002), http://www.mofa.go.jp/mofaj/gaiko/kankyo/wssd/koizumi speech.html, (accessed 12 January 2007).
} 
international environmental policy, as it had in its domestic environmental policy, "from ignorance to symbolic steps and then to substantive but essentially technocratic efforts to remedy environmental problems". ${ }^{27}$

Japan's GEP has developed as a result of internal and external pressures to follow the notion of sustainable development. Although the policy emphasizes that importance, what has been achieved domestically has not been reflected in its overseas policy activities. What has been overlooked or ignored by the Japanese government is that its domestic environmental problem remedies have been implemented in a highly organised society and one that has a strong 'groupism' mentality. These solutions do not necessarily transplant well in poorer developing countries that do not have adequate finance or infrastructure to support them.

\section{The trio behind the GEP}

One benefit that Japan wished to gain from its ODA in developing countries was an improvement in its image overseas; it wanted to change from being seen as an environmental predator as in the 1980 s to a country now focused on sustainable development. Although Japan's GEP has shown positive aspects, there is little evidence to suggest that it has included an ethical element in its brief.

There are three powerful and influential ministries within the Japanese government that shape its GEP. The Ministry of the Environment (MOEN) is the key policy initiator, the Ministry of Foreign Affairs (MOFA) plans the environmental foreign diplomacy, and the Ministry of Economy, Trade and Industry (METI) is involved in the technical area. Although the three Ministries have different priorities, their White Papers clearly state the importance of achieving the norm of sustainable development.

\footnotetext{
${ }^{27}$ Maull, “Japan's global environmental policies”, in A. Hurrell and B. Kingsburry (eds.), The international politics of the environment, p. 355.
} 


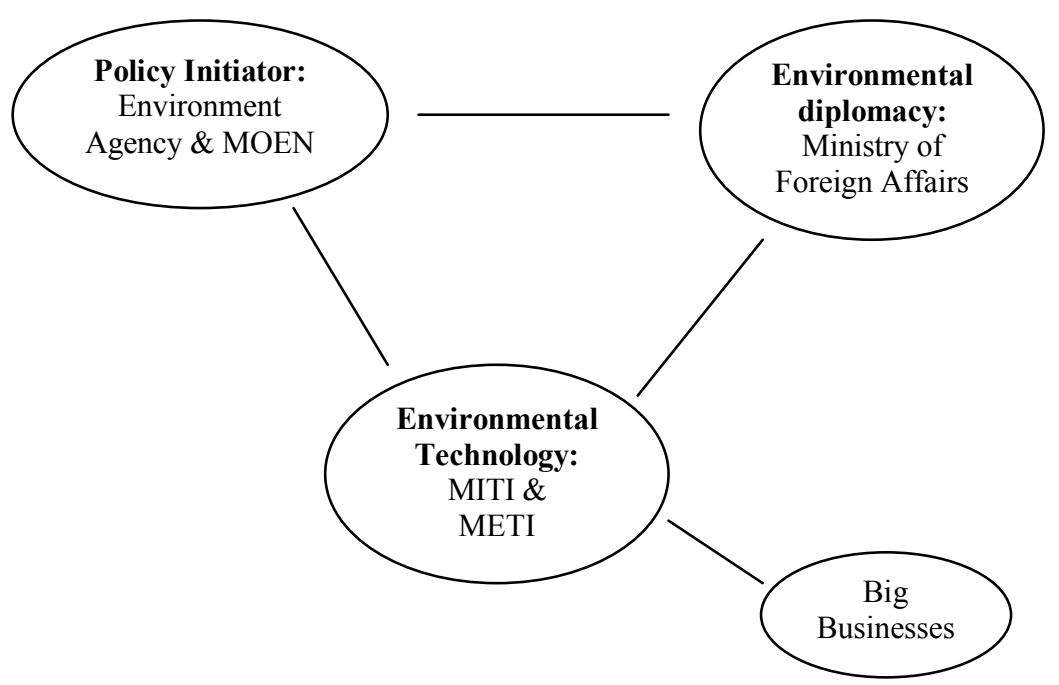

Source: compiled by the author

\subsection{The Ministry of the Environment}

Since 2001 the MOEN since 2001 continues to have the same responsibilities as were covered previously by the Environmental Agency. When setting agendas for global environmental issues, the Global Environment Bureau (GEB) in the MOEN takes responsibility for promoting the policy, participating in and negotiating international meetings on global environmental issues, and administers the cooperation with the involved countries. The focus of the GEB in 2001 followed the concept of sustainable development, 'preserving the riches of the global environment for future generations'. ${ }^{28}$ The MOEN not only promotes the country's GEP but also promotes itself as the conductor of the government's environmental policies. Since the first acknowledgment of global environmental problems two decades ago, the MOEN has published detailed analyses of global warming prevention strategies, ozone layer protection, and other pollution related issues. Japan has been very good at articulating the problems, but has not been very effective in informing the public of the seriousness of the threat. There was also little

\footnotetext{
${ }^{28}$ Ministry of the Environment, '21 seiki kankyō no seikiwo mukaete (the $21^{\text {st }}$ Century - Century of environment)', June 2001, p. 9.
} 
mention of the causes and effects of current problems, but there is little doubt that global environmental problems have been caused by the industrialization and exploitative practices carried out over the years by the developed countries. The environment is a complex system. Human intervention changes the natural flow of the interacting forces and it is significant that the GEP avoids accepting responsibility for the damage to the environment. The MOEN has detailed the interrelationship of causes that contribute to global environmental problems but it has not given details of the causes which are as important as the consequences of global environmental concerns.

One of the policy agendas that the MOEN participates in is in measures to prevent continual global warming. The reduction of $\mathrm{CO}_{2}$ emissions is not only the responsibility of the MOEN but also of the other Ministries. However, although the MOEN in general plays the central role, the global warming issue puts it in the frustrating position of having to accommodate to the aims of the METI. In 2004 Japan ranked as the fourth largest emitter of $\mathrm{CO}_{2}$ gas through its use of fossil fuels. In emitting 1.2 billion tons, Japan is ranked fourth after the U.S., China, and Russia, and had twice the emissions of the United Kingdom. $^{29}$

In 2005, the MOEN released figures on Japanese greenhouse gas emissions; it was about 1.4 billion tons, an increase of 8.1 percent against the 1990 level and an increase of 0.6 percent compared to the previous year. ${ }^{30}$ Table 1 reveals that in spite of target levels set by the government, the business sector had the biggest increase over 1990 levels. The industrial sector was the only one to show an improvement, but the target set by the MOEN of a 6 percent reduction compared to the 1990 level has lagged far behind.

\footnotetext{
${ }^{29}$ Energy Information Administration, official energy statistics from the U.S. government, 2006 http://www.eia.doe.gov/pub/international/iealf/tableh1co2.xls, (accessed on 4 April 2007).

${ }^{30}$ Ministry of the Environment, 2005, Chikyū ondanka taisaku (Climate change measures), 2005, http://www.env.go.jp/press/file view.php?serial=8615\&hou id=7603, (accessed on 12 January, 2007).
} 


\section{NOTE:}

This table is included on page 103

of the print copy of the thesis held in

the University of Adelaide Library.

Source: Climate change measures, Ministry for the Environment, Japan. ${ }^{31}$

The MOEN has limited power but it has conducted a successful working relationship with the public through the use of a 'soft power' approach. In 2005, Prime Minister Koizumi continued to develop Japan's global environmental program through his domestic Koizumi $K \bar{o} \bar{o}$ (Koizumi Initiatives). He introduced two schemes, the '3R Inishiatyibu (3R Initiatives)' and the 'Küru Bizu (Cool Biz)', as a part of the government's plan to reduce excessive consumerism and to reduce $\mathrm{CO}_{2}$ emissions. The '3R Initiatives' of Reduce, Reuse and Recycle, have recently been strongly promoted by the Government. The GEB believed that to achieve sustainable development compatible with the environment and the economy, the $3 \mathrm{R}$ initiatives were the key to success in all countries, regardless of whether they were developed or developing. ${ }^{32}$ The 'Cool Biz' program was another soft power approach that the government initiated to help combat global warming; the MOEN led a campaign targeted at Japanese white-collar workers with the slogan, 'no-tie and no-jacket'. It believed that this change of dress would reduce the amount of electricity used by air conditioners during the summer period. The government also sought to involve not only offices, but also department stores. The Association of Japanese Department Stores, comprising 98 member companies with 275 stores, willingly initiated a promotion for a new summer fashion for white-collar workers to accommodate a temperature setting of 28

\footnotetext{
${ }^{31}$ Ministry of the Environment, 2005, Chikyū ondanka taisaku (Climate change measures).

32 The global environmental bureau in the Ministry of Environment, "3R initiative, kakuryō kaigō ni tsuite (regarding the ministerial meeting of 3R initiatives)", Kankyō (Environment), March 2005, p. 16.
} 
degrees. ${ }^{33}$ Following the summer campaign, in 2005 the MOEN introduced the so-called 'Warm Biz' campaign, an approach to reduce power consumption by cutting back on heating during the winter period.

Continuing into 2005 the Ministry took the radical and rather impressive step of initiating a campaign to reduce $\mathrm{CO}_{2}$ emissions through a national education movement. Two months after Japan ratified the Kyoto Protocol, the Ministry promoted 'Minna de tomeyō ondan ka (We can stop global warming!)' by asking for a positive and substantive involvement from the society. The stated target of a 6 percent reduction of $\mathrm{CO}_{2}$ emissions was to be integrated into everyday life by such means as adjusting air conditioner temperatures, water conservation, and less motor vehicle use. ${ }^{34}$ There is now a growing movement among the public to cut back on unnecessary waste by reducing the practice of using throwaway items: 'watashi no kappu (my cup)', 'watashi no baggu (my bag)' and 'watashi no hashi (my chopstick)', are three such items. The Japanese public has willingly participated in these schemes because of environmental concerns but it is difficult to see them as being successful in developing countries. Although the MOEN is the key policy maker in setting Japan's GEP, the final power in determining the policy lies with the MOFA and the METI.

\subsection{The Ministry of Foreign Affairs}

An often overlooked feature in the development of Japan's GEP is the significant role that the MOFA plays. Along with the MOEN, the MOFA believes that it is imperative to tackle global environmental problems. Whilst the MOE is the developer of the policy, the MOFA is the face of Japanese environmental diplomacy abroad. The MOFA pledges contributions to environmental related international organizations, and environmental ODA to developing countries; its further significance lies in the fact that it adds an international diplomatic flavour to the GEP. The MOFA deals with similar areas to the MOEN but it places more emphasis on the international contribution to environmental issues. Areas that the MOFA are concerned with are climate change, ozone protection,

\footnotetext{
${ }^{33}$ The Association of Japan department store, "Hyakka ten gyōkai no 'Cool Biz to Warm Biz' (Department store's 'Cool Biz and 'Warm Biz')”, Kankyo, December 2005, p. 6.

${ }^{34}$ Ministry of the Environment, "Minna de tomeyō ondanka (We do stop global warming)", http://www.env.go.jp/earth/ondanka/kokumin, (accessed 23 September 2006).
} 
acid rain in the East Asian region, biodiversity, and other related areas. In respect to the Convention on International Trade in Endangered Species of Wild Fauna and Flora (CITES), the MOFA stated that science, not emotion, should play the leading role in determining the policy. Danaher pointed out that the CITES is the most widely accepted conservation agreement, as it is an agreement between governments. ${ }^{35}$ The purpose of the CITES is to ensure that international trade in animal and plant species does not threaten their survival; currently CITES has 171 member countries. ${ }^{36}$ The MOFA stated that in developing guidelines for the protection of endangered species, it is important to follow a scientific basis and the Japanese government continues to pursue the dictum of the sustainable use of animals. ${ }^{37}$ This is one example of how the Japanese government views global resources. The MOFA considers that animals and plants should be utilized in a sustainable way, although this does not mean that it ignores animal protection. Animals and plants are to be used for the sustainable development of human kind and this strong belief ensures that Japan remains one of the world's largest importers of wildlife. ${ }^{38}$ Surely this is not a fact that the MOFA would like to be publicised. What Mark Brazil said in the early 1990s is still valid: "wildlife is thought of as a resource, often an economic one". 39

\subsection{Ministry of Economy, Trade and Industry}

The third element involved in Japan's GEP is the METI. The MOEN administers the policy, the MOFA uses its diplomatic resources, and the METI embraces a technological approach. The METI's role is significant for the Japanese economy: its focus in the application of the GEP centres on securing the energy resources that the Japanese economy depends upon. When it deals with environmental problems, the METI endeavours to combine energy resources with environmental issues; it measures energy saving tactics to combat environmental problems. As the METI's main brief is to the Japanese economy, its interpretation is economic sustainability rather than the familiar theme of environmental

\footnotetext{
${ }^{35}$ M. Danaher, "Nature conservation, environmental diplomacy and Japan”, Asian Studies Review, vol. 23, no. 2,1999 , p. 249.

${ }^{36}$ Convention on International Trade in Endangered Species of Wild Fauna and Flora, http://www.cites.org/eng/disc/what.shtml, (accessed 9 April 2007).

${ }^{37}$ Ministry of foreign Affiars of Japan, Chikyū kankyō mondai, kokusai kankyō kyōryoku to wagakuni no gaikō, 2005, http://www.mofa.go.jp/mofaj/gaiko/kankyo/pdfs/mon gaiko.pdf, (accessed 31 March 2007).

38 Danaher, "Nature conservation, environmental diplomacy and Japan", p. 258.

${ }^{39}$ M. Brazil, "The wildlife of Japan: A $20^{\text {th }}$ Century naturalist's view", Japan quarterly, July-September 1992, vol. XXXIX, no. 3, p. 335.
} 
sustainability. However, even though the METI's priority is the Japanese economy, its contribution to environmental technology is a key element in Japan's GEP. All three ministries advocate the importance of technological input to help solve environmental problems.

In the area of environmental technology, the New Energy and Industrial Technology Development Organization (NEDO) under the METI plays an important role and is the leading organization in that field. The NEDO was established by the Japanese government in the 1980s and is now the country's largest public research and development organization involved in developing environmental technologies. ${ }^{40}$ Some of the types of technologies being developed are waste water treatment, energy from hydrogen, electricity powered vehicles, cars using 'green diesel', photo synthesis, and technologies intended to implement 3R initiatives. ${ }^{41}$ Without doubt the technologies developed by the NEDO under the METI umbrella are constructive in solving environmental problems; the down side is that technologies can often stimulate and accelerate consumer appetites.

The METI has put a great deal of money and effort into improving environmental related technology using its scientific and technical expertise. In that field Japan was in 2003 the second largest spender on research and development in the OECD, spending some US\$114 billion or around 17 percent of the total. ${ }^{42}$ One area that demonstrates METI's belief in technological solutions is its strong support for nuclear power development in spite of the inherent dangers of that process. In order to achieve sustainable development the METI acknowledges that a successful society needs to have compatibility between its economy and the environment. The METI is an important partner in Japanese economic policy making and it also desires to influence Japan's GEP in the policy direction of advanced environmental technology.

\footnotetext{
${ }^{40}$ New Energy and Industrial Technology Development Organization, http://www.nedo.go.jp/introduing/about.html, (accessed on 10 April 2007).

${ }^{41}$ Ibid.

42 Organization for Economic Co-operation and Development, science, technology and industry scoreboard 2005, briefing note for Japan, http://www.oecd.org/dataoecd/18/21/35471711.pdf, (accessed on 2 February 2007).
} 


\section{Japan's policy approach}

The Japanese government has been positive in its participation in international environmental negotiations (mentioned in the first section), notably in attending and hosting seminars. Nevertheless, Mike Danaher argued that "there remains a major gap between playing international host and actually making the necessary changes to policymaking and implementation, very important for nature conservation". ${ }^{43} \mathrm{He}$ added that "genuine policy leadership is needed, rather than 'host' leadership". ${ }^{44}$ At the 'Aichi Expo Forum' organized by Asahi Shimbun in 2002, participating Japanese panellists suggested that Japan needed to change its path from 'Keizai Taikoku (Economic Superpower)' to 'Kankyō Taikoku (Environmental Superpower)'. ${ }^{45}$ Although it is impressive that Japan wants to be a Kankyō Taikoku, there seems to be a long way for the country to go in order to achieve that ambition. The very essence of a public policy starts with a consideration of what the problems are and what it is that is hoped to be achieved; financial benefits alone will not necessarily ensure an outcome that is morally acceptable. The Government has taken at least three approaches in its GEP to achieve leadership in global environmental issues, and to become a Kankyō Taikoku.

\subsection{Japan's Business Community}

There is a close relationship between the policies of the GEP and the politics of the Japanese business community both have gained from the other and both have a common view that technology is the solution to current global environmental problems. Japan's position as a world economic superpower ensures that the GEP can have a significant effect for its big business and for general business activities.

Japanese companies quickly responded to the government's policy as they also believe that the concept of sustainable development is the path to follow. However, Jonathon Taylor noted that the term can be deceptive when he said, "What is often sustained is development

\footnotetext{
${ }^{43}$ Danaher, "Nature conservation, environmental diplomacy and Japan", Asian Studies Review, vol.23, p.267268.

${ }^{44}$ Ibid., p. 268.

${ }^{45}$ Asahi Shimbun, 14 November 2002.
} 
itself as previously practiced, not the environment". 46 There is no doubt that Japanese businesses wished to maintain sustainable business development, but in order to do this they needed to come to grips with the environmental concerns rather than to ignore them. Not only does the Japanese business community have an influential voice in government policy making, but it also has uniform business tactics to fit within Japan's GEP. An example is the Environmental Management Systems Standard (ISO14001) issued in 1996, a voluntary scheme to encourage environmental conservation activities within corporations. By 2006, about 103,583 companies worldwide had adopted the standard, which included about 20,000 Japanese companies; Japan has the highest uptake of any nation. ${ }^{47}$ Even though it is a voluntary scheme, the high uptake showed that Japanese companies took a positive approach towards tackling the problems. There is a great deal of status for companies that adopt the system and many have implemented an environmental conscious management for their survival. The rationale for this is that the Japanese society believes that companies should exist for the benefit of society. ${ }^{48}$

The Japanese business community tries to accommodate with the government's GEP, but at the same time aims to maintain economic growth. There is reciprocity as the GEP attempts to oblige the interests of Japan's business community such as Nippon Keidanren (Japanese Federation of Economic Organizations, hereafter Keidanren). However Japan's GEP has been a rather weak protector of the environment when preservation comes into conflict with economic progress. Schreurs pointed out that "Japan excelled in the implementation of environmental policies that could be made to fit in with the interests of the business community". 49

Japan's business community has seen environmental issues as a potential business opportunity. When the OECD reviewed Japan's environmental performance it noted that environment related employment represented about 1.2 percent of the total workforce; that amount would grow and environmental management and sustainable development were increasingly to become a part of Japan's local economic development. ${ }^{50}$ This suggests that

\footnotetext{
${ }^{46}$ J. Taylor, “Japan's global environmentalism: rhetoric and reality”, Political Geography, 18, 1999, p. 357.

${ }^{47}$ Worldwide number of ISO14001, http://www.ecology.or.jp/isoworld/english/analy14k.htm, (accessed 14 April 2007).

${ }^{48}$ Mitsuhashi, Kankyō keizai nyūmon (Introduction to environmental economics), p. 176.

${ }^{49}$ Schreurs, Environmental politics in Japan, Germany, and the United States, p. 252.

${ }^{50}$ OCED, Environmental performance reviews on Japan, Paris - 11 January 2002, p.9 http://www.oecd.org/dataoecd/0/17/2110905.pdf, (accessed on 5 January 2006)
} 
the Japanese government had hoped to make its GEP move in parallel with its economic policies. A Japanese government bureaucrat from METI stated that an environmental related industry would vitalize the Japanese economy; in 2002 it was worth US\$480 billion and was expected to grow to about US\$670 billion within ten years. ${ }^{51}$ The government hoped that the GEP and economic policies would coalesce, suggesting that the primary concern of the bureaucrats and the Japanese business community was economic productivity rather than environmental preservation.

In February 2005 when the Kyoto Protocol went into effect, Japan's businesses believed that the key to solving global environmental problems was through long-term technological innovation and that innovation included the use of nuclear power, a method of electricity generation that does not directly emit $\mathrm{CO}_{2}{ }^{52}$

Three powerful Japanese business bodies, the Keidanren, the Japan Chamber of Commerce \& Industry, and the Japan Association of Corporate Executives, have significant political influence on government policy, and that was applied to Japan's GEP. Nevertheless, the Keidanren has been proactive in addressing the environmental concerns and in 1991 it wrote the Keidanren Chikyū Kankyō kenshō (Charter for the Keidanren Global Environment); the basic principles of the charter emphasized the preservation of the environment and sustainable development. ${ }^{53}$ Since then the Keidanren has advocated the importance of global environmental issues; for example, in January 2007 it delivered its vision for the future with the theme, 'Kibo no Kuni, Nihon (Land of Hope, Japan)'. The main agenda concerned environmental and energy policies and stressed the value of measures for addressing global environmental problems and sustainable growth. ${ }^{54}$

The significance of the political pressure that the Keidanren could exert on the government through its considerable financial power should not be overlooked. In 2005 it donated US\$24 million to the Liberal Democratic Party and about US\$600,000 to the Democratic Party of Japan. ${ }^{55}$ It would suggest that the Keidanren was able to influence Japanese policy making that had the potential to effect business activity and economic performance.

\footnotetext{
${ }^{51}$ Asahi Shimbun, 14 November 2002.

${ }^{52}$ Ibid., 16 November 2005.

${ }^{53}$ H. Ishi, Kankyō zei toha nanika (What is the environmental tax?), Iwanami Shoten, Tokyo, 1999, p. 50.

${ }^{54}$ Keidan ren bijon, 'Kibō no kuni, Nihon' (Keidanren's vision), Nippon Keizai dantai rengō kai, 1 January 2007, http://www.keidanren.or.jp/japanese/policy/2007/vision.html, (accessed on 29 March 2007).

${ }^{55} \mathrm{http}: / /$ ratio.sakura.ne.jp/archieves/2006/09/12063847.php, (accessed on 30 March 2007).
} 
However, Keidanren's chairman, Fujio Miterai, argued at a press conference in May 2006 that donations to political parties were a contribution to the society by the Japanese corporations for successful policy implementation. ${ }^{56}$

In an effort to reduce Japan's $\mathrm{CO}_{2}$ emissions, the Ministry of Environment plans to impose a tax on fossil fuel use such as petroleum, coal, and natural gas. This would raise the price of fuel but would give the government a source of income to devote to the reduction of $\mathrm{CO}_{2}$ emissions. However, the Keidanren feels that such a tax would slow down the Japanese economy. The Keidanren acknowledged that Japan should shoulder a large share of the burden of global environmental initiatives, but in regard to the tax issue it wanted to see an increase in consumption tax, rather than an introduction of a carbon tax. ${ }^{57}$ In opposing a carbon tax the Keidaren estimated that the revenue from such a tax would be approximately US\$9.5 billion, an amount that could be raised by just an increase of 0.3 percent on the current 5 percent consumption tax. ${ }^{58}$ Carbon dioxide reduction is an extremely sensitive topic among Japanese business leaders as they believe that an introduction of a carbon tax would affect business confidence; it is not an option that the Keidanren would endorse.

Naturally there are quite different views on the carbon tax issue. At a meeting with the Environment Minister Yuriko Koike in 2004, Yōichi Morishita, Chairman of the Matsushita Electric Industrial Co. Ltd., firmly opposed the introduction of a carbon tax. He stated very clearly that the key to reducing $\mathrm{CO}_{2}$ was to further improve technology and energy saving products, and not to introduce the tax. ${ }^{59}$ However, Hiromitsu Ishi, the Chairman of the Tax Commission in Japan agreed that a carbon tax was an effective method to combat climate change. He said that the four Northern European countries of Finland, Sweden, Norway, and Denmark had introduced one between 1990 and $1992 .{ }^{60}$ The Japanese government has certainly been reluctant to show flexibility in its examination of a tax format to help combat global environmental degradation. It could be argued that the Japanese government accommodates to the Japan's business community and so the GEP is crafted to suit economic performance. As Ishi pointed out, the government's direct

\footnotetext{
${ }^{56}$ Keidanren, http://www.keidanren.or.jp/japanese/speech/20060524c.html, (accessed on 29 March 2007).

${ }^{57}$ Schreurs, Environmental politics in Japan, Germany, and the United States, p. 171.

58 Asahi Shimbun, 8 December 2003.

${ }^{59}$ Nihon Keizai Shimbun, 26 April 2004.

${ }^{60}$ Ishi, Kankyō zei toha nanika (What is the environmental tax?), p. 148.
} 
control through regulations has traditionally been the most favoured approach among the business community rather than through an economic approach with the introduction of an environment tax. ${ }^{61}$ Since the 1990s the government emphasized the need for compatibility between business activity and the preservation of the environment. Its persistent reluctance to implement a carbon tax demonstrated the government's priority towards the business sector typified by the willingness of the Keidaren to give precedence to the economy over the environment.

A stated objective of the Japanese GEP was to help preserve the natural environment and to cooperate with other governments; however, what was not stated was that such a policy should not undermine Japanese economic activities. Pempel's argument in 1982 concerning Japan's environmental policy, that there was a great reluctance on the part of Japanese bureaucrats to let environmental concerns interfere with government economic policies, is still valid. ${ }^{62}$ In 2002 , the OECD recommended that Japan strengthen and extend the use of economic instruments such as taxes to implement its environmental policy in more environmentally effective and economically efficient ways. ${ }^{63}$ A similar view was expressed by Lester R. Brown, president of the Earth Policy Institute, who believed that a carbon tax was the key to changing societal behaviour. ${ }^{64}$ Brown further stressed that a carbon tax was the way to maintain a harmonious relationship between the economy and the environment; the system needed to reduce income tax as it introduced a carbon tax on production processes and industries that emitted greenhouse gases. ${ }^{65}$

As the policy developed further, Japanese companies began to create an image to fit in with government initiatives. Japanese companies have been forced in the $21^{\text {st }}$ century to change from "mōkeru dake no kigyō (a company that only wants profits)" to "Kankyō ni shinken ni torikun de iru kigyō (a company that seriously works on environmental issues)". ${ }^{66}$ The Japan External Trade Organization (JETRO) reported in 2006 that there was a significant increase in environmental awareness among Japanese companies in their business activities. The JETRO stated that in the corporate strategy there was a strong

\footnotetext{
${ }^{61}$ Ishi, Kankyō zei toha nanika (What is the environmental tax?), p. 40.

${ }^{62}$ T. J. Pempel, Policy and politics in Japan, creative conservatism, Temple University Press, Philadelphia, 1982, p. 226.

${ }^{63}$ OCED, Environmental performance reviews on Japan, Paris - 11 January 2002, p. 3. http://www.oecd.org/dataoecd/0/17/2110905.pdf, (accessed on 5 January 2006).

${ }_{64}$ Asahi Shimbun, 8 December 2003.

65 Ibid.

${ }^{66}$ Mitsuhashi, Kankyō keizai nyūmon (Introduction to environmental economics), p. 188.
} 
trend away from environmental preservation to environmental management. ${ }^{67}$ The report also stated that more companies in Japan have been using the term 'environmental' to effect a change of image and that it had become an important business tactic. ${ }^{68}$ It had been a common belief that environmental efforts were a financial burden, but in recent years a significant number of businesses had engaged in environmental related activities and have come to realize that they could be linked to increased profitability. ${ }^{69}$

Japanese companies have worked together with the government to develop regulations and restrictions in regard to environmental concerns and thus have had an influence on the national policy. Hatakeyama, Otsuka, and Kitayama pointed out that it has been difficult for companies to follow the environmental laws as they were becoming extremely complicated. Hatakeyama and the others assumed that the government would undertake a supporting system for voluntary contributions from the companies, rather than the companies having to comply with the government laws, reasoning that it was less of a burden on companies and a lesser cost to the government administration. ${ }^{70}$ Norman Bowie, an influential voice in business ethics, believes that business does not have an obligation to protect the environment; however, "it does have a moral obligation to avoid intervening in the political arena in order to defeat or weaken environmental legislation."71

The Japanese GEP has been built on its domestic environmental policy and then adjusted to suit the country's favoured economic strategy; however, the two policies were developed from opposite directions. The Japanese GEP was started by pressure from international organizations and scientists and has been less transformed in comparison to its domestic policy, a policy that developed from grass roots initiatives.

A major weakness of the Japanese GEP is that it was greatly influenced by the Keidanren: the policy was conceived and developed by economists whose aim was to produce cost

\footnotetext{
${ }^{67}$ Japan External Trade Organization, 2006, “Kankyō jūshi no shisei o tsuyomeru Nihon kigyō (Japanese companies who strengthen their stance on the importance of the environment)", http://www3.jetro.go.jp/jetro-file/BodyUrlpdfDown.do?bodyurlpdrf=05001269 001 BUP 0.pdf, (accessed on 19 January 2007).

68 Ibid.

${ }^{69}$ K. Arai, "New business from recycling", Asia Pacific Perspectives, vol.1, No.4, August 2003, p. 20.

${ }^{70}$ Hatakeyama, Otsuka and Kitamura (eds.), Kankyō hō nyūmon (Introduction to the environmental law), p. 198.

${ }^{71}$ N. Bowie, "Morality, money, and motor cars" in M. Hoffman, R. Frederick and E. Petry, Jr. (eds.)

Business, ethics, and the environment, the public policy debate, Quorum Books, New York, 1990, p. 89.
} 
effective results and who believed that they should address ends rather than means. In contrast, philosophers look at the intergenerational factor of the well being of future generations and it cannot necessarily be met by using today's values. Environmental groups in Japan do not have the backing or support of the government and so they are unable to influence it to apply a philosophical input into the policy; they cannot match the political power of big business. Bromley and Paavola stated that environmental policy should be about who we are and who we wish to become: ${ }^{72}$ this philosophical element has been ignored in the GEP and the policy yhas therefore questions of ethicality.

\subsection{Environmental ODA}

In developing Japan's GEP, environmental ODA played a key role. The policy makers used sustainable development as their theme when tackling environmental problems in developing countries. There were two themes that the Japanese government promoted: 'participation and contribution'. According to a media report by the Global Environment Bureau in the Ministry of Environment in July 2005, the government was keen to further strengthen Japan's positive role in environment ODA and technological transfer, especially into Asia. ${ }^{73}$ However, the transfer of Japanese technology in an effort to resolve global environmental problems has often resulted in further problems, rather than solutions. Jonathan Taylor argued that the promotion of Japan's technological solutions was actually a contributing factor to many problems; the issues of local autonomy, environmental ethics, aesthetics, and traditional culture were often ignored. ${ }^{74}$ Peter Dauvergne also pointed out that there was a tendency, especially within government, to assume that environmental technologies were beneficial. ${ }^{75}$ Jun Ui, the prominent and well-known environmental critic, questioned the use of science and technology. He said that science and technology are value neutral as they can be both effective and ineffective. ${ }^{76}$ The Japanese government

\footnotetext{
72 D. Bromley and J. Paavola, "Economics, ethics and environmental policy" in D. Bromley and J. Paavola (eds.), Economics, ethics and environmental policy, contested choices, Blackwell Publishers, Malden, MA, 2002, p. 275.

${ }^{73}$ Ministry of the Environment, International Environmental Cooperation toward sustainable development, Environmental Cooperation Office, Global Environment Bureau, 8 July 2005, http://www.env.go.jp/earth/coop/coop/arikata j.html, (accessed 9 February 2007).

${ }^{74}$ Taylor, "Japan's global environmentalism: rhetoric and reality", Political Geography, p. 553.

${ }^{75}$ P. Dauvergne, Shadows in the forest, Japan and the politics of timber in Southeast Asia, Massachusetts Institute of Technology Press, Cambridge, 1997, p. 13.

${ }^{76}$ Takagi Fund on 20 June 2004, http://www.takagifund.org/08/ui/ui01.html, (accessed on 12 February 2007).
} 
is rather confident in the use of the country's sophisticated technology as a part of environmental ODA, and it believes that it has helped many developing countries. However, Dauvergne criticised Japan's ODA because of the effect of Japan's 'shadow ecology', that is, the environmental impact on resource countries that have been caused by government practices such as corporate conduct, investment and technology transfers, trade, and import tariffs. ${ }^{77}$ Japan's environmental ODA programs appear to focus very much on technology, but technological transfer is a strategy used by the government to expand its power and influence in developing countries.

When the areas that the government emphasized in its environmental ODA are looked at it would seem at first to be straight forward, but upon closer examination it raises numerous questions. Relevant government websites cover inhabited environment, forest preservation, pollution measures, disaster prevention, water preservation, and climate change problems. The amount of Japanese environmental ODA is about 30 percent of total annual bilateral aid, ${ }^{78}$ and its environmental ODA is in fact gradually increasing. The 2004 ODA White Paper stated that 58.8 percent of its Environmental ODA is by loans, about 25.2 percent by grant aid, and 16.9 percent by technical cooperation. ${ }^{79}$ In 2003 , the Japanese government revised its ODA Charter for the first time in 11 years; it opened the Charter with the words "to contribute to the peace and development of the international community and thereby to help ensure Japan's own security and prosperity". ${ }^{80}$ It does appear that the country's environment ODA favours involvement in developing countries that have natural resources of interest to Japan and that the ODA in turn contributes to its prosperity. Whilst this serves Japan's economic interests, it may not stand up to scrutiny on ethical grounds.

Japan's Government Technical Cooperation Program, also known as the 'Green Aid Plan' (GAP), was started in 1992 by the Ministry of International Trade and Industry (MITI, renamed METI in 2001). According to Wataru Yamamoto from the Japan Development

\footnotetext{
${ }^{77}$ Dauvergne, Shadows in the forest, Japan and the politics of timber in Southeast Asia, pp. 2 - 3.

${ }^{78}$ Ministry of Foreign Affairs of Japan, "Japan's environmental ODA - strategy progress towards sustainable development" http://www.mofa.go.jp/policy/oda/category/environment/pamph/2001/oda.html, (accessed 12 September 2005).

${ }_{79}$ Ministry of Foreign Affairs of Japan, 2005 ODA Hakusho (2005 ODA White Paper), http://globalwarming.mofa.go.jp/mofaj/gaiko/oda/shiryo/hakusho/05 hakusho/ODA2005/html/zuhyo/index.h $\underline{\mathrm{tm}}$, (accessed on 7 October 2005).

${ }^{80}$ Ministry of Foreign Affairs of Japan, Seifu kaihatsu enjo taimou no kettei ni tsuite (About decisions on Official Development Assistance), August 2003, http://www.mofa.go.jp/mofaj/gaiko/oda/seisaku/taiko.html, (accessed on 9 February 2007).
} 
Institute of Engineering and Consulting Firms Association, the objective of GAP is to support developing countries both in environmental and energy matters, such as air and water pollution prevention, water and recycling treatments, energy conservation and alternative energy sources. ${ }^{81}$ Yamamoto remarked that 'Brown Aid' was a better term to use than 'Green Aid' when describing GAP programs carried on between MITI and recipient countries when the projects weren't requested from the governments of the recipient countries. These projects were coordinated by the JETRO through Japanese embassies. $^{82}$ As mentioned, about 60 percent of environmental ODA is by loan and the Japan Bank for International Cooperation (JBIC) is the key financial provider. The JBIC has also committed to environmental issues as it stated that it would help realize 'sustainable development' in developing countries. ${ }^{83}$ In fact, the areas emphasized by the JBIC on environmental issues resemble the government technical cooperation program GAP. According to the JBIC, renewable energy resources, forest conservation and reforestation, and seeking to have partnerships with international organizations, are the areas that it would put an effort into in order to support environmental conservation. ${ }^{84}$ What has not been mentioned in the official aid environmental program is the number of energy related projects. To mention just two, a geothermal power plant in Mexico and a hydroelectric power plant in the Chinese Zipingpu dam project indicate that these types of projects have now become a significant part of Japan's environmental ODA.

One characteristic that is often seen in Japan's overseas ODA programs is that it concentrates too much on technological innovation and technological transfer; what may work in a country that has supportive infrastructure may well fail in a developing country. In spite of the fact that Japan emphasises sustainable development, in many cases the programs fail to take into account the outcomes and can seriously harm the viability and sustainability of the local environment. It is the moral responsibility of those implementing the programs to ensure that they are considered from the viewpoint of the local community. Yuriko Kawaguchi, Japan's first Minister for the Environment, expressed her vision of global environmental concerns when she said that environmental

\footnotetext{
${ }^{81}$ W. Yamamoto, 'Japanese Official Development Assistance and Industrial Environmental Management in Asia', which was presented at the Nautilus Institute Workshop on Trade and Environment in Asia-Pacific, on September 1994 at Honolulu, http://www.nautilus.org/archives/papers/enviro/trade/odaasia.html, (accessed 12 February, 2007).

${ }^{82}$ Ibid.

${ }^{83}$ Japan Bank for International Cooperation, http://www.jbic.go.jp/english/base/about/environ/index.php, (accessed 9 February, 2007).

${ }^{84}$ Ibid.
} 
policy making should be looked at "seikatsu suru hito no shiten de (through the eyes of the people who live there)". ${ }^{85}$ Kawaguchi's view is shared by many academics, including Bruno S. Frey, who believes that decisions about environmental policy should be decentralised and made at the lowest possible level, preferably in the local community. ${ }^{86}$

The application of Japanese ODA raises questions of its legitimacy because those involved with implementing the projects have often failed to liaise at the local community level; these are the people who are most often adversely affected by the projects. The Japanese government funded projects often create serious damage to the regional environment of the recipient countries. To quote just two instances, according to Rivers Watch East and Southeast Asia (RWESA), the Koto Panjang Dam project in Sumatra, and the San Roque dam project in the Philippines, threatened the local environments. RWESA argued that before the aid project in Sumatra was implemented the area had a rich natural environment, but that now wildlife and native elephants were threatened with extinction; meanwhile in the Philippines the livelihood of more than 20,000 indigenous people was threatened. ${ }^{87}$ The social and ecological damage caused by these two projects indicate that they are only the tip of the ODA mismanagement iceberg. It goes without saying that the Japanese environmental ODA and GAP have failed according to the criteria of environmental and economical success and have totally ignored the social and cultural aspects of the ethnic groups in the project regions. Professor K.S.Jomo from Malaysia is critical of Japan's environmental ODA. He pointed out that dam construction displaces communities, destroys farmland by flooding, forests by inundation, and the natural environment and ecosystems further down the valley. ${ }^{88}$ Hideka Yamaguchi from the University of Delaware supported that view saying that evidence shows that environmental problems such as ecosystem degradation and loss of social and cultural values have been particularly significant in Japanese ODA projects designed specifically for the energy sector. ${ }^{89}$

\footnotetext{
${ }^{85}$ Y. Kawaguchi, "Kokunai deno jisseki wo tsukurukoto ga nihon no chikyū kankyō he no kōken to naru (Establishing an actual achievement will lead Japan to contribute to the global environment)", Gaikō Fōramu, no. 146 , October 2000, p. 11.

${ }^{86}$ B. S. Frey, "Morality and rationality in environmental policy", Journal of consumer policy, 22, 1999, p. 413.

${ }^{87}$ Development and disasters, Japanese-funded dam projects in Asia, published collaborations by Rivers Watch East and Southeast Asia (RWESA) and Friends of the Earth Japan in March 2003, p. 8.

${ }^{88}$ Jomo K.S. "Malaysian forest, Japanese wood, Japan's role in Malaysia's deforestation” in Jomo. K.S. (ed.), Japan and Malaysian development, in the shadow of the rising sun, Routledge, London, 1994, p. 192.

${ }^{89}$ H. Yamaguchi, “Assessing the sustainability of Japan's foreign aid program: an analysis of development assistance to energy sectors of developing countries", Bulletin of Science, Technology \& Society, vol. 25, no. 5, October 2005, p. 412.
} 
International Rivers Network's Peter Bosshand argues that large dams are among the most socially and environmentally risky and controversial of infrastructure projects, and that there are three significant impacts from these projects. ${ }^{90}$ He said that the first is the social impact that causes the displacement of millions of people; the second is the environmental impact that large dams contribute to greenhouse gas pollution through methane emission; and the third is the economic impact. The benefits of projects have often been vastly overestimated whilst at the same time the real costs have been vastly underestimated. ${ }^{91}$ The environmental ODA does appear to favour developmental ODA that has close links with companies that are involved in the construction of energy generating plants; this shows that business interests would appear to be more important than genuine environmental protection. Marie Söderberg pointed out that Japan's foreign aid program is rather an economic co-operation program. ${ }^{92}$ Söderberg also emphasized that through the significant increase of its environmental ODA, Japanese business opportunities linked to foreign aid would increase, as would the profits of those companies involved. ${ }^{93}$

Japan's ODA environmental projects are mostly applied to developing nations where poverty and environmental degradation are serious problems. The stated mission of the ODA is to help minimize environmental degradation and to improve the quality of life in the local communities. A considerable number of projects, particularly those associated with dam construction, result in the local people being displaced and left in a far worse position. Whilst Japanese environmental ODA projects bring substantial and sustainable opportunities for Japanese business, they do not necessarily convey similar benefits to the local communities or to their environment. Paul Wapner describes those people who reside in the resource supply areas as living in a 'shadow ecology'; "Shadow ecologies and the dynamics of exploitation that occur within them make explicit the issue of environmental ethics". ${ }^{94}$ Wapner raised the further points of justice, fairness, and moral

\footnotetext{
${ }^{90}$ P. Bosshard, "Introduction", in A Trojan Horse for large dams, how export credit agencies are offering new subsidies for destructive projects under the guise of environmental protection, The Corner House, Environmental Defence, FERN, Friends of Earth Japan, the Halifax Initiative, International Rivers Network, Probe International, and the World Development Movement, published on September 2005. The publication report was prepared by ECA WATCH.

${ }^{91}$ Ibid.

${ }^{92}$ M. Söderberg, “Japanese ODA - what type, the whom and why?”, in M. Söderberg (ed.), The business of Japanese foreign aid, five case studies from Asia, Routledge, London, 1996, p. 33.

${ }_{93}$ Ibid., p. 84.

94 P. Wapner, "People, nature, and ethics", Current History, November 2000, vol. 00, no. 640, p. 357.
} 
worth if those people who live in the shadows are treated as less deserving than those who enjoy the benefits of the resources. ${ }^{95}$

What is concerning about the ODA in Japan's GEP is that it does not appear to be sufficiently flexible; it persists with sophisticated technology in an endeavour to resolve current problems. Japan wants not only to export its technological innovations, but also expects the recipient communities to adapt to the 'Japanese concept' of sustainable development, a sustainable economic development in harmony with the environment. This approach can create problems as the Japanese interpretation of sustainable development lacks the element of environmentally sustainable improvement. Without question a technological input is important, but the Japanese formula may not suit all situations in the community at large. The overemphasis of technology can be seen as an opportunity to expand Japanese business interests abroad; Japan's policy makers are confident that technological innovation is the way to solve current environmental problems such as global warming and the reduction of $\mathrm{CO}_{2}$ emissionns. The Japanese government has made it very clear that global environmental issues are a top priority in its foreign affairs policy, and promised to make a positive contribution by making the best use of Japan's extensive experience and up-to-date technology. ${ }^{96}$ However, in spite of the government's target, the Japanese state of the art technology has had limited success in reducing domestic $\mathrm{CO}_{2}$ emissions. They have in fact been gradually increasing as the MOEN reported that emissions in 2005 were 1.3 billion tons, an 8.1 percent increase over the 1990 level. $^{97}$

Japan's environmental ODA policy focuses on solutions through technology but the country has a moral responsibility to ensure that the solutions do not prove to be a disaster for the recipient countries in the long term. Technical solutions are mostly concerned with cost/benefit results and do not take into account non-cost social values when weighing up the viability of projects. In discussions about the environment Jonathon Taylor observed that the term 'sustainable development' can be a deceptive one; he stated that "what is often to be sustained is development itself as previously practiced, not the environment". ${ }^{98}$

\footnotetext{
${ }^{95}$ Wapner, "People, nature, and ethics", p. 357.

${ }^{96}$ Ministry of Foreign Affairs, the government of Japan, http://www.mofa.go.jp/policy/un/pamh2000 achieve/global.html, (accessed 2 January 2007).

${ }_{97}$ Ministry of the Environment, 2005 nen do no onshitsu kōka gasu haishutsu ryō sokuhyōchi (the amount of greenhouse gas emissions in Japan, 2005), http://www.env.go.jp/press/fileview.php?serial=8615\&hou id=7603, (accessed 12 January 2006).

${ }_{98}$ Taylor, "Japan's global environmentalism: rhetoric and reality", Political Geography, p. 357.
} 
It is worth noting how the concept of sustainable development has now been replaced with the idea of sustainable growth. ${ }^{99}$ The concepts of growth and development seem similar, but sustainable growth can be interpreted to place greater emphasis on economic growth than does sustainable development. Japan's GEP approach, one that is closely attached to the country's big corporations, emphasizes environmental ODA as the key to expand economic opportunities overseas. Overseas sustainable development is to be used as a strategic tool, and sustainable growth is to be used to ensure future returns to Japan.

\subsection{Environmental technology}

The core component in Japan's approach to environmental problem solving is technology and there is no doubt that is has been an important tool in combating ecological problems, as well as being an important ingredient in the domestic environment policy. Technology can help prevent further environmental degradation and improve the living amenity; however it is given great prominence in Japan's GEP as the government sees the need to maintain its technological advantage in order to be an Environmental Superpower. The 2008 Japanese Environment White Paper strongly emphasized technological innovation in environmental areas; it stated that Japan should not neglect technological development in order to become a Kankyō Rikkoku (Environmental State), and that it needs to continue to pursue the highest technological advances in environmental areas. ${ }^{100}$

There are two reasons why the GEP focuses on technology. The first is its support for Japanese business interests as it is business that develops technological innovations; in the government's vision for an 'Environmental State' business and technology go hand in hand. One advantage of Japan being an 'Environmental State' is that it creates 'Green employment' opportunities. Asahi online news reported in January 2009 that Japan's environmental business had by 2006 generated about 1.4 million employment opportunities. $^{101}$ Japan certainly has the trained manpower to gain from this expanding

\footnotetext{
99 A. Brennan, "Environmental decision-making" in R. J. Berry (ed.), Environmental dilemmas, ethics and decisions, Chapman \& Hall, London, 1993, p. 5.

1002008 Environment White Paper, the Ministry of Environment, http://www.env.go.jp/policy/hakusyo/h20/pdf/full.pdf, (accessed 10 March 2009).

${ }^{101}$ Asahi online news, 'Midori no koyō, Kankyō shō ga teian (the Ministry of the Environment proposes Green Employment)', 7 January 2009, http://www.asahi.com/eco/TKY200901060337.html, (accessed 7 January 2009).
} 
sector and Japan's Global Environment Centre Foundation has listed some of the technologies; continuous water pollution monitoring, air and water pollution control, soil and groundwater contamination surveying and countermeasures, among others. ${ }^{102}$ Japan has the technology to help with the problems of air and water pollution in the developing countries; however, Sharon Beder stated that Western technology may cause problems in developing countries and as well cause economic and self-sufficiency problems. ${ }^{103}$ Technology is important for the prevention of ecological damage, but exporting Japanese technologies such as monitoring systems is a very favourable way for Japan to create business opportunities.

The second reason for Japan's technological approach is that it closely equates with the nation's energy policy. Japan is well known for its active $3 \mathrm{R}$ recycling program, but the slogan also includes 'Shōene (省エネ: saving energy)'. A shōene awareness has been beneficial in creating an environmental consciousness that brings benefits to the industries who produce shōene items, and to the consumers who choose shōene products. The relationship between technology and energy is becoming important in both the environmental policies and the energy related policies. Japanese technology that focuses on shoene aims at benefiting the environment and assisting business growth. The NEDO focuses on energy research development and some 'green' technologies; it has focused on solar energy, wind and biomass energy, natural gas cars, and hybrid cars. ${ }^{104}$

In order to become an 'Environmental State', technology plays a crucial role. When Shinzō Abe became Prime Minister in September 2006 the MOEN proposed Kankyo Rikkoku (環境立国: Environment State); the idea was to sell Japanese experience, and Japan as a mentor, to the rest of the world. The MOEN stated that Japan had both experience and highly advanced environmental technologies upon which to build a 'Japan model' for overseas enterprises, promoting technology as well as sustainable economic growth. $^{105}$

\footnotetext{
${ }^{102}$ Global Environment Centre Foundation, http://www.gec.jp/gec/database/index-j.html, (accessed 11 March 2009).

${ }^{103}$ S. Beder, The nature of sustainable development, Scribe publications Pty Ltd., Newham, 1996, p. 221.

${ }^{104}$ New Energy \& Industrial Technology Development Organization (NEDO), http://app2.infoc.nedo.go.jp/kaisetsu/egy/index.html, (accessed 12 March 2009).

${ }^{105}$ Ministry of the Environment, 21 seiki kankyō rikkoku senryaku (Strategy to be the Environmental State in the $21^{\text {st }}$ century), http://www.env.go.jp/guide/info/21c ens/21c strategy 070601.pdf, (accessed 11 March 2009).
} 


\section{Conclusion}

In the late $1980 \mathrm{~s}$ the Japanese government committed to contribute towards the preservation of the global environment. Although the key element of the policy purported to ensure continuing sustainable development, within the policy there was also the aim of seeing that that there was a continuing supply of natural resources flowing into Japan. Japan's ODA is used as a tool in that process and many in the government see the aims of the policy to be a matter of national security. Without question, Japan's global environmental initiatives have see n a significant improvement in the country's environmental policy, such as establishment of the BEL in 1993, and being the host of UN sponsored Kyoto Conference in 1997. Although the policy has presented some positive aspects, there is little to support the suggestion that it has included a Japanese ethical element. The policy is lacking in ethical considerations not only because it is directed by a trio whose aim is sustainable development, but also because it does not give equal consideration to the resource supplying countries.

Ethical considerations are imperative and are needed as a guide for the future; they maintain the values of a fair and sustainable society for coming generations (discussed in Chapter one). The three pillars on which Japanese environmental policies should be built are the responsibilities of business and environmental policy makers, the support of the disadvantaged groups in the society, and an acknowledgement of the values of local expertise and experiences, are not reflected in Japan's GEP. Although there are differing interpretations of ethical values, a consideration of future generations should be a universally accepted concept.

The next chapter, which looks at Japan's Whaling Policy, reveals a similar vision, one of sustainable development. The policy continues the fight for the legalization of commercial whaling in order to sustain the whaling industry and Japan's national pride. 


\title{
CHAPTER FOUR: Case study 1
}

\author{
THE WHALING POLICY \\ Whales and whaling - a cultural or ethical conflict?
}

Japan is one of the few countries in the world that is determined to bring about the return of commercial whaling. In spite of the enormous criticism from environmentalists, governments abroad, and anti-whaling proponents, the Japanese government has not wavered in its strong belief that it has a right to conduct whaling. The government sees whales as a resource to be used, rather than as a marine species to be protected. This chapter examines the ethical framework of Japan's whaling policy.

The practice of whaling has been subject to much discussion world-wide and raises many contentious issues. The political, cultural, ecological, and personal beliefs which are expressed in those discussions make the whaling issue extremely complicated; this has been particularly so since the 1987 International Whaling Commission (IWC) moratorium. Scholars such as Mike Danaher, Amy Catalinac, ${ }^{1}$ and others, have commented on Japan's whaling practices; in the discussions however, very little attention has been given to an examination of the policy from a moral perspective. An ethical framework in a whaling policy can be defined as one that considers sustainability, sustainable development, and environmental ethics. Since the moratorium, Japan's whaling policy has focused on its scientific research program with the anticipation that it will lead to a recommencement of commercial whaling. The policy takes the narrow view of the commercial value of whales, but it fails to acknowledge their significant ecological value. A similar fixation on commercial aims at the expense of the environment is shown in the chapters following, forestry and nuclear energy.

This chapter is divided into four parts. The first part examines the background to the development of Japan's whaling policy from the pre-World War II period to the present

\footnotetext{
${ }^{1}$ Mike Danaher's article, 'Why Japan will not give up whaling', in Pacifica Review in 2002, and Amy Catalinac and Gerald Chan's article, 'Japan, the West, and the whaling issue: understanding the Japanese side', in Japan Forum in 2005.
} 
time. The second part analyses Japan's scientific research program, a focal point of Japan's whaling policy. The third part analyzes the main organizations behind the whaling policy. The three main players that shape the policy direction are government bureaucrats, the semi-government Institute for Cetacean Research, and the fishing industry represented by the Japan Fisheries Association; these constitute Japan's 'whaling triangle'. The final part of the chapter explores the ethical aspect of the whaling policy which is shaped by this triangle.

\section{The development of Japan's whaling policy}

The history of the development of the policy can be seen as extending over three eras. The first era encompassed small scale community enterprises, the second was the expansion to large commercial operations, and the third was the introduction of the scientific research program.

\subsection{The period prior to World War II.}

Japan's whaling first began as an opportunistic coastal activity: it was known as 'passive whaling' and took advantage of beached whales. ${ }^{2}$ Arne Kalland and Brian Moeran pointed out that whales were occasionally hunted by bow and arrow and by nets, but most were taken in the form of dead or wounded animals that drifted by. ${ }^{3}$ History records that whales were first caught by the use of hand harpoons in the $12^{\text {th }}$ century. ${ }^{4}$ Catalinac and Chan state that scholars believe that organized whaling commenced around Taiji in the $16^{\text {th }}$ century and quickly spread to other coastal villages. ${ }^{5}$ The bounty was shared among the local communities, and the manner in which each community prepared and ate its whale

\footnotetext{
${ }^{2}$ A. Catalinac and G. Chan, "Japan, the West, and the whaling issue: understanding the Japanese side", Japan Forum, Vol. 17, No. 1 March 2005, p. 136.

${ }^{3}$ A. Kalland and B. Moeran, Japanese whaling, end of an era?, Curzon Press Ltd., London, 1992, p. 65.

${ }^{4}$ Nihon hogei kyokkai (Japan Whaling Association), http://www.whaling.jp/history.html, (accessed 1 August 2007)

${ }^{5}$ Catalinac and Chan, "Japan, the West, and the whaling issue: understanding the Japanese side", Japan Forum, p. 136.
} 
meat was a source of pride and identification. The ritual had a religious aspect and each region had its own unique set of Shinto shrines and festivals. ${ }^{6}$

Organized whaling in Japan commenced in the $17^{\text {th }}$ century and developed into a fishing industry. In 1606 Yorimoto Wada, from the Taichi region of Wakayama, encouraged the development of a new technique for hunting whales by using harpoons. ${ }^{7}$ At that time the whole of the whale resource was fully used; the meat was used for human consumption, and the bones and internal organs were used for fertilizer. ${ }^{8}$ The transportation of the produce was carried out by ships and Japan's first lighthouse, which was built in 1636 at the Cape of Taiji, used whale oil as fuel for its light. ${ }^{9}$ It is not known exactly how many whales were taken annually at that time but it appears that there were sufficient to justify the establishment of reliable marine transportation, evidenced by the building of lighthouses.

During the Tokugawa or Edo period (1603-1868) whaling practices seem to have been confined to small coastal activities, but in 1863 a new era dawned. In that year Commodore Perry in his black ships forced Japan to open its doors to the United States; it was historically significant for Japan, and economically valuable for the US as it enabled American whaling vessels to be resupplied. ${ }^{10}$ Towards the end of the $19^{\text {th }}$ century, Russia embraced what is known as the 'Norwegian method' of whaling, one that used harpoon guns mounted on steam powered whaling ships. ${ }^{11}$ Due to the abundant whale resources the Russian whalers were very successful and overwhelmed the Japanese industry. In 1898 Russia exported about 1,000 tons of whale meat to Japan, whilst at that time Japan's domestic catch in each whaling port was only around 15 whales per year. ${ }^{12}$ As a consequence of the Russian proficiency, the Japanese whalers quickly realized the commercial significance of adapting to the new method; they quickly moved away from traditional methods and started a modern whaling industry. By the end of the $19^{\text {th }}$ century

\footnotetext{
${ }^{6}$ Kalland and Moeran, Japanese whaling, end of an era?, pp. 155-156.

${ }^{7}$ K. Nasu, Hogei seisuiki (The story of whaling's rise and fall), Kourin, Tokyo, 1990. p. 39.

${ }^{8}$ Ibid., p. 39.

${ }^{9}$ Ibid., p. 39.

${ }^{10}$ K. Sumi, "The 'whale war' between Japan and the United States: problems and prospects", Denver Journal of International Law \& Policy, 1989, vol. 17, no. 2, p. 318.

${ }^{11}$ Kalland and Moeran, Japanese whaling, end of an era?, p. 75.

${ }^{12}$ Nasu, Hogei seisuiki (The story of whaling's rise and fall), p. 52.
} 
Japan's whaling had become a valuable enterprise and, as it entered the new century, began to mature as an industry.

In 1900 the Ishikawa-Jima ship building company built the first vessel specifically designed to use the Norwegian technique; it weighed 11 tons and started operating in the Korean Channel. ${ }^{13}$ By 1907 there were 12 whaling companies established around Japanese coastal waters. ${ }^{14}$ As more whaling companies were established the consumption of whale meat in Japan also increased; in 1930 the annual consumption reached 30,000 tons, three times greater than in 1913, while in 1939, just before the Pacific War, consumption reached 45,000 tons. $^{15}$ The Japanese whaling industry was a very profitable business until the start of the Pacific war in 1941 when it was forced to stop the practice as most of its whaling vessels had been requisitioned for war use.

\subsection{The Post World War II period until 1986}

At the end of World War II Japan faced defeat, devastation, and a severe shortage of food. Fishing had always played a major role in the Japanese economy and, particularly during the post-war period, the development of the industry depended heavily on resources outside of Japan's three-mile territorial seas. ${ }^{16}$ A similar situation applied to whaling. As a result of the war, by 1945 Japan had lost 95 percent of its whaling vessel tonnage and at the same time, because of food shortages, it had become more dependent than ever on whale meat to supply protein to its people. ${ }^{17}$

During the US occupation the Japanese whalers started to re-establish their industry and there were two reasons for this. Firstly, the Japanese government saw whales as an important fish resource that could be obtained, and secondly, General Douglas MacArthur encouraged Japan to resume whaling in the Antarctic as a means to provide additional

\footnotetext{
${ }^{13}$ T. Hara, Za Kujira (The whales), Bunshin do, Tokyo, 1993, p. 228.

${ }^{14}$ Ibid., p. 229.

${ }^{15}$ Nasu, Hogei seisuiki (The story of whaling's rise and fall), p. 55.

${ }^{16}$ T. Akaha, Japan in global ocean politics, University of Hawaii Press, Honolulu, 1985, p. 19.

${ }^{17}$ Kalland and Moeran, Japanese whaling, end of an era?, p. 88.
} 
protein to the diet of the Japanese people. As a consequence, by the late $1950 \mathrm{~s}$ whale meat accounted for approximately 47 percent of all animal protein consumed by the Japanese. ${ }^{18}$

The IWC was established in 1948 due to US initiatives; ${ }^{19}$ it comprised a number of nations that were concerned for the welfare of whales and the whaling industry. However, the prelude to the IWC was the establishment of the International Convention for the Regulation of Whaling (ICRW) in December 1946, in Washington USA. ${ }^{20}$ The purpose of the ICRW was "to provide for the proper conservation of whale stocks and thus make possible the orderly development of the whaling industry". ${ }^{21}$ Peter Stoett believed that the American government wanted to encourage private global investment in whaling, and in the trading of whale products. ${ }^{22}$ The Japanese government saw benefits in being involved with the IWC and in 1951 Japan became a member; the legitimacy of Japan's commercial whaling was established at that time under IWC whaling regulations.

From then on Japan's whaling industry grew considerably. According to Kalland and Moeran, "by 1960-61 Japan was sending seven fleets to the Antarctic, and in the following season production reached an all-time peak of more than 300,000 tons of whale oil and meat". ${ }^{23}$ By 1963 the Japanese consumed more whale meat than any other type of meat and by 1965 Japanese whalers were taking nearly 27,000 whales a year. ${ }^{24}$ But as the industry grew, it became apparent that the whale resource was becoming increasingly scarce. During the 1960s the IWC member countries realized that it was inevitable that if whaling continued at the same levels, then some whale species were headed for extinction. In 1963 the IWC decided to prohibit the hunting of humpback whales, and two years later the hunting of blue whales. ${ }^{25}$ These prohibitions had a tremendous impact on Japanese whaling interests. Whaling had grown to become an important industry, but its supervision by the Ministry of Agriculture, Forestry and Fisheries (MAFF) had not guaranteed its orderly development. Japan's whaling was regulated under the Fisheries Law and in order

\footnotetext{
${ }^{18}$ K. Shima, “Japan and whaling”, Social Science Japan, August 1999, p. 3.

${ }^{19}$ P. Stoett, The international politics of whaling, UBC Press, Vancouver, 1997, p. 57.

${ }^{20}$ J. Cherfas, The hunting of the whale, a tragedy that must end, Penguin books, London, 1989, p. 111.

${ }^{21}$ International Whaling Commission, http://www.iwcoffice.org/commission/iwcmain.htm, (accessed 4 March 2007).

22 Stoett, The international politics of whaling, p. 57.

${ }^{23}$ Kalland \& Moeran, Japanese whaling, end of an era?, p. 89.

${ }^{24}$ R. Friedheim, "Moderation in the pursuit of justice: explaining Japan's failure in the international whaling negotiations", Ocean development \& international law, 27, no.4, 1996, p. 353.

${ }^{25}$ Sumi, "The 'whale war' between Japan and the United States: problems and prospects", p. 325.
} 
to operate, all whaling vessels were required to obtain a license from the MAFF. Kazuo Sumi pointed out that these licenses were meant to control excessive numbers of whaling vessels, but until the mid-1960s the Japanese government did not exert that control. ${ }^{26}$ The obvious reason for this was that the Japanese whaling and general fishing industry was able to exert its considerable power on the government.

Growing global environmental awareness, and the related social movements in the early 1970s, had a tremendous impact on whaling issues, particularly for pro-whaling countries such as Japan. That awareness was heightened by the 1972 United Nations Environment Program (UNEP) and brought about the first major turning point in Japan's whaling practices. The UNEP changed the focus of the IWC and this change had a momentous effect. Stoett stated that the 1972 conference generated more action and awareness about the global environment than more recent conferences could ever hope to. ${ }^{27}$ The change emphasized the preservation of the whale species rather than just the use of that resource. At the UNEP the United States took the lead in proposing a 10-year moratorium on commercial whaling. ${ }^{28}$

As a result of the global environmental crusade, Japan's whaling industry struggled to survive. Whaling had been a valuable part of the Japanese fishing industry and in the 1970s the government, through the Fisheries Agency, held that whaling was still a valuable activity. From the 1960s until the late 1970s the amount of whale meat consumed by the Japanese remained constant, whilst the consumption of other meat grew significantly (see Graph 1).

\footnotetext{
${ }^{26}$ Sumi, "The 'whale war' between Japan and the United States: problems and prospects", p. 351.

27 Stoett, The international politics of whaling, p. 65.

${ }^{28}$ Sumi, "The 'whale war' between Japan and the United States: problems and prospects", p. 329.
} 


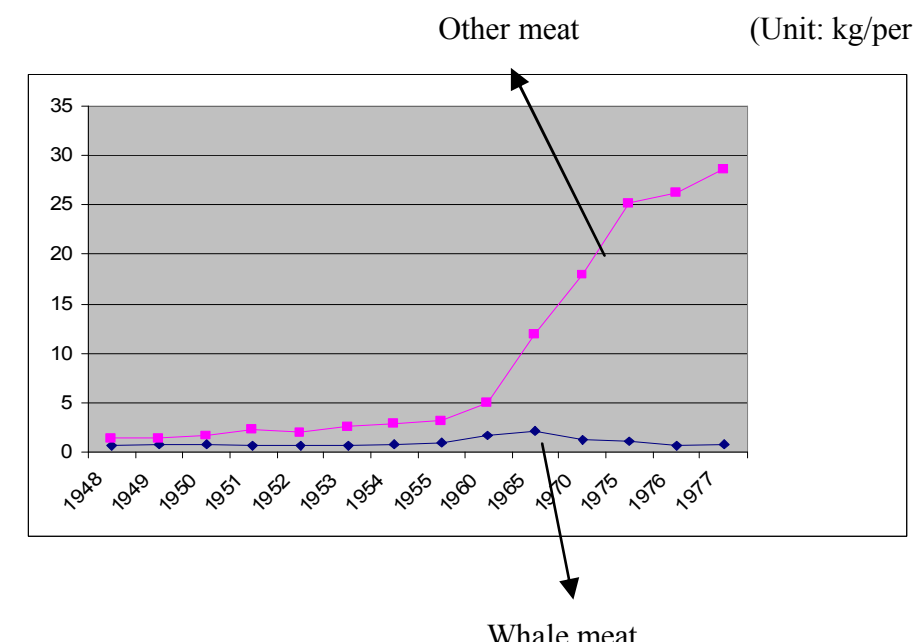

Source: Compiled by the author from Japan's whale meat supply data, available at: http://www/,abprpsjo-ch.com/ata/lif 12 2.htm, (accessed 21 April 2008)

In 1975 the price of chicken meat was for the first time cheaper than that of whale meat; at that time chicken was $¥ 99$ per kilo whilst whale was $¥ 103$; since then the price of whale meat has continued to rise in comparison. ${ }^{29}$ The combination of a growing environmental awareness, and the availability of alternative cheaper meat, meant that whale meat consumption in Japan remained static. However, this was not reflected in the government's determination to maintain whale meat trading. In 1978 Japan imported a total of $\$ 30$ million worth of whale meat, comprising 2,600 tons from Spain, 600 tons from Somalia, and 2,780 tons from Cyprus. ${ }^{30}$

During the 1970s Japan's management of whale products was questioned as the government had failed to address the problem of pirate whaling. Although the practice was first revealed in 1976, the illegal trading in whale meat had started much earlier. Between 1971 and 1974 the pelagic whaling company Nittō Hogei had imported illicit meat from the (re-flagged) former Dutch ship Sierra. ${ }^{31}$ 'Eco', a voice for conservationists, alleged that the whaling practice by Japan's Taiyo fishing company was the most

${ }^{29}$ Geiniku kakaku to shokuniku kakaku no suihi (A comparison of the price between whale meat and other meat), http://www.maboroshi-ch.com/ata/lif 12 3.htm, (accessed 21 April 2008).

${ }^{30}$ Hara, Za Kujira (The whales), p. 68.

${ }^{31}$ Ibid., p. 72. 
egregious of whaling crimes when in 1968 the company became involved in pirate whaling through a joint venture with Norwegian whaling interests. ${ }^{32}$ The Japanese government took formal legal action in 1979 to prohibit the importation of whale products from nonIWC member countries. ${ }^{33}$

A further turning point in whaling activities occurred at the 1982 IWC meeting. At that meeting, in spite of disapproval from its Scientific Committee, a moratorium on commercial whaling from the year 1986 was adopted. Keiko Hirata commented that the architect of the moratorium was the United States; it played a major role in promoting an anti-whaling base by using its domestic laws to enforce the moratorium through the threat of economic sanctions against whaling nations. ${ }^{34}$ An example is that the US threatened the Japanese government that it would terminate its fishing quota in the US 200 mile Exclusive Economic Zone if Japan did not comply with the moratorium. Access to those fishing grounds was more important to Japan than was whaling, ${ }^{35}$ and in order not to damage this arrangement the Japanese reluctantly complied. As the general Japanese fishing industry played a significant role in Japan's economy, the government had little choice but to favor it over the narrower whaling interests.

Due to the global environmental awareness movements that grew in the developed nations throughout the 1970s, whaling in general was seen as an undesirable practice, and this sentiment continued to be expressed throughout the 1980s. As a result of the growing antiwhaling sentiment, the direction of the IWC gradually shifted from harvesting whales to preserving them. The year 1986 saw an end to a centuries-long tradition of whaling, but it did not see an end to the Japanese government's determination to resume and justify the practice.

\footnotetext{
${ }^{32}$ Eco 2006, report from the International Whaling Commission Annual Meeting, http://www.earthisland.org/immp/ECO2006/issue1.html, (accessed on 28 September 2006)

${ }^{33}$ Sumi, "The 'whale war' between Japan and the United States: problems and prospects", Denver Journal of International Law \& Policy, p. 355.

${ }^{34}$ K. Hirata, "Beached whales: Examining Japan's rejection of an international norm”, Social Science Japan Journal, p. 8 .

${ }^{35}$ M. Danaher, "Why Japan will not give up whaling", Pacifica Review, vol.14, no. 2, June 2002, p.116.
} 


\subsection{The moratorium period from 1987}

Japan's whaling policy was faced with a major challenge from the effects of the 1987 moratorium. The moratorium did not bring an end to its policy aims but prompted the government to keep its commercial whaling aspirations alive by making use of a so called 'scientific research program'. That research not only legitimizes Japanese whaling activities but was the only option available to Japan if it was to continue whaling under the IWC. As well as Japan, Norway and Iceland are also allowed under the 1946 IWC Charter to conduct whaling research, a process that the Commission supports. It is stated in Article VIII of the Charter that, "notwithstanding anything contained in this Convention any Contracting government may grant to any of its nationals a special permit authorizing that national to kill, take and treat whales for purposes of scientific research subject to such restrictions as to number and subject to such other conditions as the contracting government thinks fit, and the killing, taking, and treating of whales in accordance with the provisions of this Article shall be exempt from the operation of this Convention". ${ }^{36}$

The moratorium was originally planned to last for five years. In the early 1990 s, the introduction of the Revised Management Procedure (RMP) was an encouraging sign for the pro-whaling countries. The RMP scheme was designed to maintain healthy whale populations that would ensure their sustainable use and at that time gave Japan reason for optimism, but the scheme failed to be implemented. The major reason for this was the overwhelming global opposition to commercial whaling.

In spite of the growing world wide desire to protect whales, the Japanese government has remained firm in its claim for the legitimacy of its whaling practices. Even though Japan argues this legitimacy, and has requested a return to commercial whaling at the annual IWC meetings, the government has not been successful. In 1994 the IWC extended further protection to whales by establishing the Southern Ocean Sanctuary, an area roughly contained in the latitudes south of Tasmania. There were two reasons for this. The first was that with the growing global environmental awareness from the 1990s, conservationists believed that whales should be protected, not harvested. The second was that many environmentalists, especially advocates for whales, hoped that by supporting the

\footnotetext{
36 'The IWC and scientific permits' by International Whaling Commission (IWC), http://www.iwcoffice.org/conservation/permits.htm, (accessed 28 August 2006).
} 
sanctuary it would shut down the practice of whaling, particularly Japan's scientific whaling. In 2008 Chile added its support to anti-whaling countries by turning its entire Pacific Ocean territorial waters into a whale sanctuary; whaling for commercial or scientific purposes would be banned. ${ }^{37}$ The Chilean President Michelle Bachelet stated that it was "a big step ahead in the protection of nature and a major legacy to future generations". ${ }^{38}$ Since the moratorium, about 11,000 whales have been taken by member countries under scientific permits issued by the IWC (see Table 2). Under these permits, the Japanese government has between 1987 and 2006 killed more than 10,000 whales. Alexander Gillespie made the point that in 2000 Japan was the only country actively conducting and expanding scientific whaling operations. ${ }^{39}$ The longer the moratorium continues, the greater becomes the Japanese government's determination to resume whaling.

The annual IWC meetings have become battle grounds for the Japanese government in its effort to convince the members that its scientific program is legitimate by providing the results of its research. The Japanese government has shown its frustration about the shift within the IWC from just preventing whaling, to the active protection of whales. One such instance occurred when the government submitted a proposal for the 'normalization' of the IWC at the $58^{\text {th }}$ IWC meeting at St. Kitts and Nevis in 2006. What Japan meant by normalization was for the IWC to focus on the original function of IWC, which it claimed (with some justification) was concerned about the welfare of the whaling industry rather than about the protection of the whales species, as advocated by anti-whaling countries. Japanese dissatisfaction was clearly seen in a media release in 2006 by Joji Morishita from the Fisheries Agency: he argued that "it's time to bring this organization back to its major purpose of managing commercial whaling, and not continue with endless, futile discussions". ${ }^{40}$ Japan has so far failed to achieve results favorable to its aims. Friedheim stated that one of the reasons for Japan's lack of success is that the majority of the IWC member countries have formed a bloc to oppose the resumption of commercial hunting. This powerful coalition is able to command the votes of three-quarters of the delegates

\footnotetext{
${ }^{37}$ The Advertiser, 17 October 2008, p. 35.

${ }^{38}$ Ibid., p. 35.

${ }^{39}$ A. Gillespie, "Whaling under a scientific auspice: the ethics of scientific research whaling operations", Journal of International Wildlife Law \& Policy, vol.3, no.1, Spring, 2000, p. 38.

${ }^{40}$ Media release, 19 June 2006, St. Kitts and Nevis, by Fisheries Agency in the Ministry of Agriculture, Forestry and Fisheries, the Government of Japan.
} 
when deciding on important whaling issues. ${ }^{41}$ The coalition has up to 2008 been successful.

In 2008 Japan continued to conduct scientific research whaling in spite of tremendous criticism from anti-whaling nations and environmental groups. Contained in the IWC Chairman's summary report of the 2007 annual meeting was the fact that the Japanese government had sought a new permit for whaling activities in the Antarctic. The new proposal sought to more than double the intake of minke whales and to have fin and humpback whales added to the targeted species of its scientific research. ${ }^{42}$ The harder Japan tries to increase its research whaling, the more the anti-whaling groups and nations resist. In December 2007 Australia took a very determined approach to Japan's scientific research expeditions. Kevin Rudd, the new Labor Prime Minister, announced that it would send a ship and an aircraft to monitor Japan's whaling vessels. It is not certain whether Australia's firm stance in the whaling war with Japan was a factor, but the anti-whaling ships Sea Shepherd and Greenpeace have aggressively tried to thwart the Japanese whaling activities over the past years.

In early 2008 the whaling war was not just contained to a confrontation between the antiwhaling ships and the Japanese whaling vessels: it also extended into the political arena. Even though Japan's whaling policy is no longer as important economically as it was, it has become a significant and symbolic issue coloured by Japan's deeply rooted cultural and nationalistic sentiments. The skirmish in the Southern Ocean was probably the first time that such an event was featured in any of the Japanese media; it portrayed the confrontation as a cultural attack. The action was widely broadcast in Japan during January 2008, and in the following month the whaling conflict was even debated in the Japanese parliament. The Japanese Prime Minister, Yasuo Fukuda, affirmed the country's claim to the legitimacy of whaling and indicated that he believed that the solutions to the whaling issues should be based on science rather than on emotional judgements. ${ }^{43}$

\footnotetext{
${ }^{41}$ Friedheim, “Moderation in the pursuit of justice: explaining Japan's failure in the international whaling negotiations", Ocean development \& international law, p. 357.

42 Chair's summary report of the $59^{\text {th }}$ annual meeting, Anchorage, Alaska, May 2007 , http://www.iwcoffice.org/ documents/meetings/ChairSummaryReportIWC59rev.pdf, (accessed 4 March 2008).

${ }^{43}$ Lower House, the government of Japan, Tōben honbun jyōhō (Text of parliamentary reply), 1 February 2008 ,

http://www.shugiin.go.jp/itdb shitsumon pdf s.nsf/html/shitsumon/pdfS/a169024.pdf/\$File/a169024.pdf, (accessed 22 April 2008).
} 
The 2008 Japanese scientific research whaling fleet returned to Japan on April 16 with a catch of 551 minke whales. It had planned to take a total of 900 whales ( 850 minke whales and 50 fin whales) but the 40 percent decrease was blamed on the numerous disturbances by the activist ships Sea Shepherd and Greenpeace. ${ }^{44}$ However, these attacks by the antiwhaling groups did not deter Japan. What is clear in Japan's whaling policy is that commercial whaling is the ultimate goal and that the policy centres on the maintenance of the whale resource in order to ensure a sustainable industry. Whaling has been an important part of Japan's fishing industry and whales are still a significant fish resource in some small Japanese communities. The severe food shortage at the end of the World War II (WWII) brought about a rebuilding of the industry and whale meat fed many Japanese from the 1950s through the 1960s. The industry might be small but there is great interest from groups connected to whaling (discussed later in this section).

\section{Scientific research whaling}

Japan's scientific research program has been central to the country's policy for more than two decades as it is the only option left for Japan to legally hunt whales. This section focuses on the nature of Japan's scientific research whaling, and an inquiry into the value of that research.

2.1. The legitimacy of the research.

In spite of international criticism, Japan has the right under IWC regulations to conduct scientific research on whales. There are three issues to look at to test the legitimacy of Japan's research; they are the permits, the objectives of the research, and a comparison with others countries that conduct scientific research.

${ }^{44}$ Chōsa hogei, mokuhyō no rokuwari domari de kikō, bōgai tsuzuku (Research whalers return to Japan with a $60 \%$ catch, the disturbance continues), Asahi Shimbun, 15 April 2008, http://www.asahi.com/special/070110/TKY200804150042.html, (accessed 22 April 2008) 
Japan currently holds two research permits to conduct whaling research, JARPA II in the Antarctic, and JARPN II in the Western North Pacific. The research in the Antarctic targets about 400 Antarctic minke whales, as well as humpback and fin, whilst in the Western North Pacific it targets about 100 minke, as well as Bryde's, sei, and sperm whales (see Table 2). ${ }^{45}$ In the years 2004 and 2005, Japan caught a total of 755 whales (it included 3 sperm, 100 sei, and 51 Bryde's). ${ }^{46}$ The high numbers of whales caught, and the quality of the scientific research, call the program into question. The Institute of Cetacean Research (ICR), the primary conductor of the Japanese whaling research, argued that large numbers are required in order to furnish adequate research data. As mentioned earlier, the 2007 IWC meeting gave Japan permission to increase its research catch, the intake of minke whales to be doubled, and fin and humpback whales to be included. Japan's entitlement to conduct the scientific research is supported by the IWC. Figure 1 lists the large whales managed by the IWC.

The second issue is the objectives and objectivity of the research program. The stated aim of the program is to learn about the biology of the whale species. While Japan's JARPN II research has two main areas of interest, the IWC has three. Japan's first objective is to ascertain whale numbers, and the second is to learn about the feeding ecology of minke whales in the Western North Pacific. ${ }^{47}$ The IWC has stated that its areas of interest are the feeding ecology of whales, the structure of the whale group, and the environmental effects on cetaceans and the marine ecosystem. ${ }^{48}$ The element of environmental objectivity would appear to be lacking in the Japanese program. Its research objectives focus on population numbers, age, birthrate and other details but there is less focus on their environmental significance and this reveals a lack of balance in the seemingly biased research. The NHK documentary program on the Japanese whaling issues on 16 December 2006, revealed that of the seven 'researchers' in the expeditions, three were university students. ${ }^{49}$ This would seem to indicate an 'in name only' research program.

\footnotetext{
${ }^{45}$ International Whaling Commission, 'The IWC and scientific permits', http://www.iwcoffice.org/conservation/permits.htm, (accessed 28 August 2006) ${ }^{46}$ Ibid

${ }^{47}$ Japan's whale research programs - Qs \& As, by the Institute of Cetacean Research, http://www.jfa.maff.go.jp/whale/document/Japan research faq.htm, (accessed 5 September 2006).

48 "Scientific permit whaling - Iceland" by the International Whaling Commission, http://www.iwcoffice.org/conservation/permits.htm, (accessed 1 September 2006).

${ }^{49}$ NHK Kyōiku terebi, ETV Sugawawa Bunta Nagagutsu no tabi, hito to kujira ga tadotta michi (A trip in wellington boots, a road passed by humans and whales by Sugawara Bunta ), 22:00-23:30, 8 December 2006.
} 
The third issue is a comparison with other countries that hold permits. An obvious difference is that Japan's scientific research attracts the most criticism and is partly due to the fact that Iceland and Norway use quite different methodologies.

There are two relevant comparative points with the Icelandic research. The first is that the program concentrates only on minke whales and only 60 are caught annually in keeping with its original research proposal. ${ }^{50}$ The second is that the Icelandic program, which attempts to increase the understanding of both the biology and the feeding ecology of cetacean species, is conducted only in its own territorial waters. ${ }^{51}$ These two points, and the small numbers of whales involved, deflect potential censure.

The situation with Norway is quite different to both that of Japan and Iceland. The Norwegian government has a legal right to hunt minke whales but this right has not been much challenged. Although the Norwegian hunt yields similar numbers of whales to Japan's, the Norwegian research is less contentious. Two reasons can be put forward to explain this. The first is that the Norwegians only target minke whales and that their hunting is conducted from small fishing vessels. ${ }^{52}$ The second is that the government only conducts its commercial hunting around Lofoten Island, an island located in Norwegian territorial waters. Although there are differences in their whaling practices, the citizens in Japan and Norway share a similar viewpoint about whales. Trond Bjorndal in Norway, and Jon M. Conrad in the United States, have pointed out that the leaders and citizens of both countries have strong feelings about the legitimacy and importance of whaling, and that they consider whaling as a management issue rather than an environmental one. ${ }^{53}$

Japan, Iceland and Norway all share the belief in the right to conduct whaling. However, the numbers, species, locations and methodology involved in the Japan's research raise continuing concerns and doubts. It could be argued that as Japan's whaling is conducted in pelagic waters, environmentalists and anti-whaling countries feel that they have a stake

\footnotetext{
50 "Scientific permit whaling - Iceland" by the International Whaling Commission, http://www.iwcoffice.org/conservation/permits.htm, (accessed 23 April 2008).

51 "Scientific permit whaling - Iceland" by the International Whaling Commission.

52 Norwegian whaling 2006, Ministry of Fisheries and Coastal Affairs, Norway, 21 May 2007, http://www.iwcoffice.org/ documents/commission/IWC59docs/59-WKM\&AWI6.pdf, (accessed 23 April 2008).

${ }^{53}$ T. Bjorndal and J. Conrad, “A report on Norwegian whale hunt”, Marine Policy, vol. 22, no. 2, 1998, p. 161.
} 
in the whales' welfare, and thus it is Japan that draws most of the adverse publicity and censure over its whaling practices.

\subsection{Concerns over the quality of Japan's scientific research}

Although Japan has continued its research for more than 20 years, the significance of the results continues to be queried. As Japan stands alone in its dependence on scientific results to justify a return to commercial whaling, its program can be questioned as regards its scope and worth.

The value of the scientific findings is queried by both anti-whaling groups and by scientists, but the Japanese government believes that science holds the key to legitimizing its research. The ICRW's Article III states that "the Schedule shall be based on scientific findings"54 and would seem to support Japan's actions. Opinion is, however, divided over the need to kill the whales. It is true that the ICRW values scientific findings but when the article was drafted in 1946 there were no viable alternatives to sampling other than by lethal methods. Japan argues that its research has contributed to an understanding of the feeding habits of whales through stomach content analysis. ${ }^{55}$ Baker and Clapham argue that stomach analysis only indicates an animal's most recent meal, and minke whales in particular consume a large variety of prey over different periods and in different regions. ${ }^{56}$ The ICR claims that they consume vast quantities of fish resources that include Pacific saury, sardine, cod, squid and mackerel, and that the total of around 400 million tons is about four times the amount consumed by humans. ${ }^{57}$

\footnotetext{
${ }^{54}$ International Convention for the Regulation of Whaling, 1946 signed at Washington, 2 December 1946, from an annual report of the International Whaling Commission 2004.

${ }^{55}$ The Institute of Cetacean Research, "Whales are increasing as fish stocks decline", Japan Times, 23 July 2001.

${ }^{56}$ S. Baker and P. Clapham, "Appendix 1: Ethics of scientific whaling: issues and alternatives", Science, profit and politics: scientific whaling in the $21^{\text {st }}$ Century, a report by World Wide Fund for Nature (WWF), June 2005, p. 34.

${ }^{57}$ The Institute of Cetacean Research, Japan Times, 23 July 2001.
} 
What the Japanese research endeavors to prove is that from an ethnocentric perspective, whales are now competing against humans for marine resources. The claim by the Japanese that whales are responsible for diminishing fish stocks discounts the consequences of over-fishing. The Japanese claim ignores the fact that whales have been a part of the marine ecosystem for millennia, and that until the depredation of ocean resources by humans, a balance has been maintained. Today the effect of human intervention is clearly shown. James Estes, an expert in the dynamics of sea mammals, stated that some orcas have now changed their diet to otters and seals in response to a shortage of their traditional food of great whales because hunting by humans has reduced their numbers far below their natural level. ${ }^{58}$ The Japanese claim further ignores the simple fact that fish themselves are eaten by bigger fish and the fact that some fish numbers are now on the increase may be because they are no longer being commercially hunted.

Eating seafood is an important part of Japan's culture; the Japanese are among the world's highest, per capita, consumers of seafood. In 2004 Japan was the largest importer of fish with around three and a half million tons compared to second-ranking China at three million; in dollar terms Japan was the highest at US\$15 billion, followed by the USA at US\$12 billion. ${ }^{59}$ The volume of fish consumed by humans calls into question the Japanese assertion of the destructive effect that whales have on marine resources.

The second aspect is killing methodology. As mentioned, Japan claims that it needs to catch and kill large numbers of whales to properly carry out stomach content analysis but there are now however much better ways of taking samples than by killing them. Baker and Clapham claim that the combination of photo identification, DNA faeces analysis, sex identification through genetic biopsy samples, and satellite tracking are far more detailed and accurate than lethal sampling, and can continue over a long period of time. ${ }^{60}$ Today, the killing of whales generally creates an emotional response and overwhelming criticism, particularly by anti-whaling groups that are located mainly in the Western countries.

\footnotetext{
58 “Cull considered for at-risk orcas", The Australian, 11 May 2009, p. 5.

${ }^{59}$ Japan Fisheries Association, Isarabi, no. 51, September 2006, http://www.suisankai.co.jp, (accessed 7 August 2007).

${ }^{60}$ Baker and Clapham, “Appendix 1: Ethics of scientific whaling: issues and alternatives”, Science, profit and politics: scientific whaling in the $21^{\text {st }}$ Century, p. 34 .
} 
Through the use of lethal research methods, animal rights are not considered, and the practice is condemned on moral grounds by animal welfare, animal liberation, and environmental groups. Some preservationists maintain that regardless of the purpose, the killing of whales is immoral when one considers their high intelligence and the part they play in the ocean's ecosystem. ${ }^{61}$

There are quite different perceptions as to the value of Japan's scientific whaling between Japan and those countries that are concerned about the program. For instance, since the start of the moratorium, the majority of IWC members have stated that scientific whaling is not necessary but grant that current research may produce 'useful results'. ${ }^{62}$ The difference here is that the Japanese government claims that its whaling research is vital and that its research will 'present a new face'. With the methods mentioned by Baker and Clapham now available to scientists, the program appears to be lacking in the true nature of scientific research.

Regarding the value of the research, Morishita from the MAAF strongly believes that the Japanese have provided sufficient data to prove that minke whales are abundant, or gradually increasing in numbers, and that this will allow for sustainable use. ${ }^{63}$ The cost of the Japanese expeditions is partly met by sales of the whale meat, with the balance met by government subsidies. In 2005, Toshiya Kasuya, who was part of the planning team for the program, made a revealing statement. He said that the Fisheries Agency had set two principal criteria for the research agenda: the first was to catch whales in order to cover the expeditions' costs, and the second was to ensure that the program was not short- term. ${ }^{64}$ It may be deduced from Kasuya's disclosure that the main purpose of Japan's scientific research program is to build a sustainable base for whaling with the hope that it will lead to a sustainable whaling industry, rather than a program concerned for the welfare of the whale species.

Figure 1 shows a list of large whales which are managed by the IWC.

\footnotetext{
${ }^{61}$ Stoett, p. 105.

${ }^{62}$ Gillespie, "Whaling under a scientific auspice: the ethics of scientific research whaling operations", Journal of International Wildlife Law \& Policy, p. 49.

${ }^{63}$ J. Morishita, "Hogei mondai no rekishiteki nenyō to shōrai no tenbō (Historical transition of the whaling issue and its future: an analytical approach by a matrix)", Kokusai gyogyō kenkyū (Journal of International Fisheries), vol 4, no.1, March 2001, p. 3.

${ }^{64}$ J. Hoshikawa, Nihon wa naze sekai de ichiban kujira wo korosunoka (Why is Japan the highest killer of whales in the world?), Gentosha, Tokyo, 2007, p. 80.
} 
Figure 1: List of large whales managed by the IWC

Blue whale

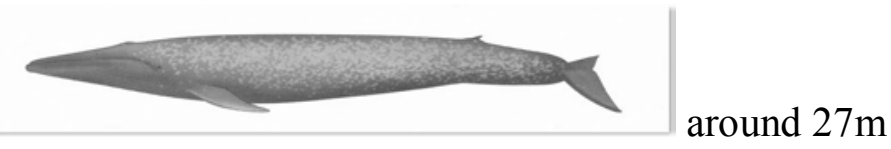

Fin whale

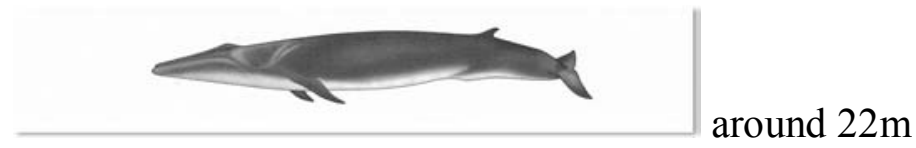

Bowhead whale

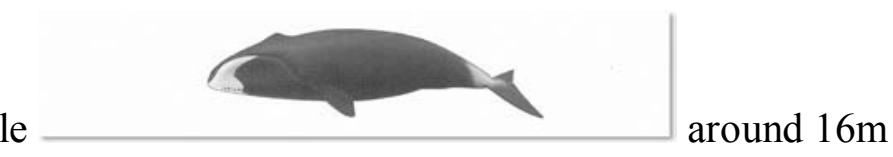

Right whale

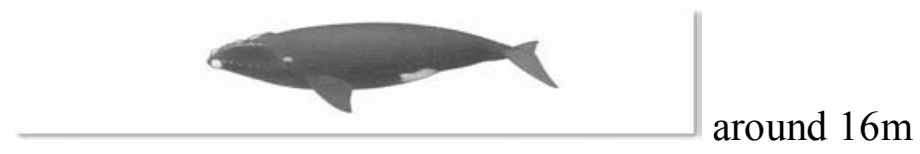

Sei whale

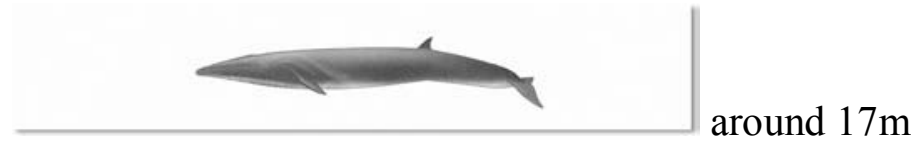

Sperm whale

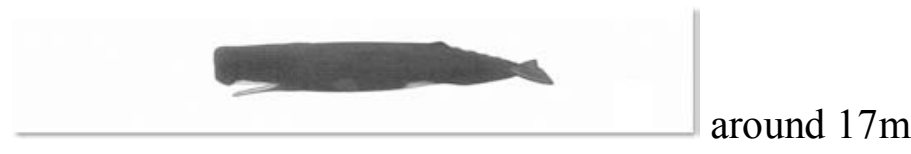

Humpback whale

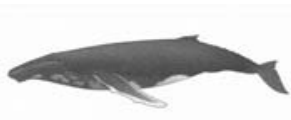

Gray whale

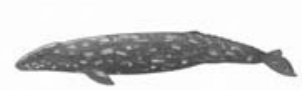

around $15 \mathrm{~m}$

Bryde's whale

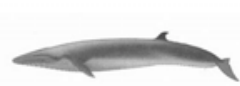

around $15 \mathrm{~m}$

Minke whale

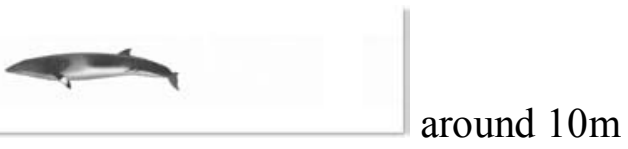

Source: Hogei to kujira (Whaling and whales), http://www.cypress.ne.jp/jf-taiji/sub03.html, (accessed 4 March 2007), compiled by the author 


\section{The trio behind the Japanese whaling policy}

The Japanese whaling policy has been primarily shaped and controlled by three entities that have formed a famed Japanese institution, a so-called 'Iron Triangle' (a close relationship between government bureaucrats, politicians, and business) which I will refer to as the 'Whaling Triangle'. Japan's whaling policy is shaped by this triangle; it comprises the Hogei-han (Whaling section) of the Fisheries Agency within the MAFF, the ICR, and the Japan Fisheries Association (JFA). The Hogei-han speaks on whaling issues and represents the Japanese government's point of view, and the ICR focuses on research whaling in collaboration with the Hogei-han. The third institution is the JFA, which stays in the background but influences the direction of the Japanese whaling policy. The influence which this triangle exerts on policy formulation has been virtually overlooked or ignored by scholars and researchers involved in the whaling debate. Figure 2 shows Japan's whaling power game, with the three central controlling players.

Figure 2: The Whaling Triangle and its associates

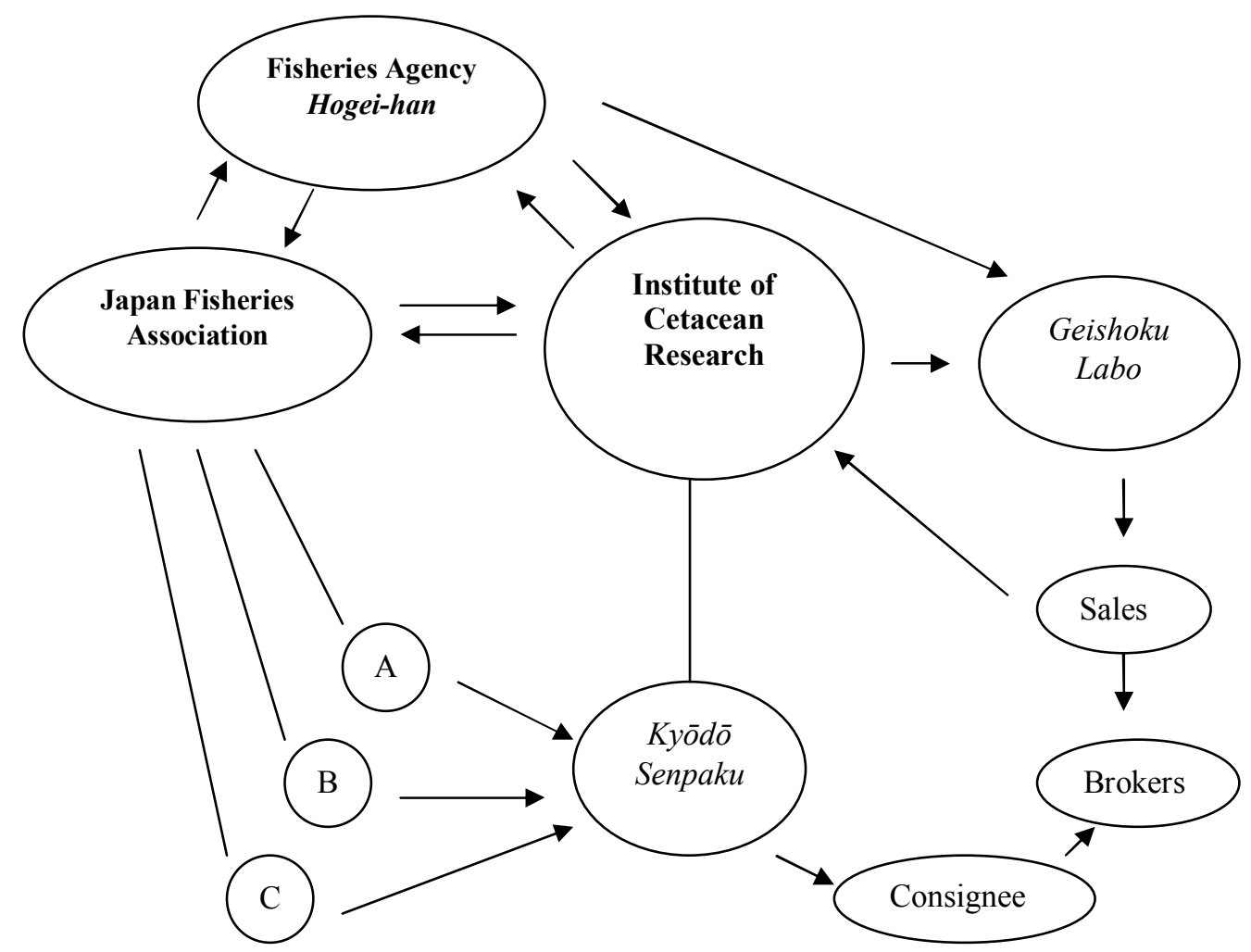

*A, B \& C represent Japanese fishing corporations 


\subsection{The Fisheries Agency - The role of the Hogei-han}

The Fisheries Agency is responsible for Japanese whaling issues: it shapes the whaling policy and exerts considerable power within Japan on these matters. The Hogei-han is a branch of Shigen kanribu enyōka (Natural Resource Management Department - Far Seas Fisheries Division) within the MAFF. Some of the Hogei-han's tasks include the issuing of permits and the supervision of whaling vessels and factory ships; its responsibility extends to the hunting of other marine mammals such as fur seals. ${ }^{65}$ However, the Hogeihan plays a much broader role than just fulfilling administrative tasks. It is the window of public relations for the whaling industry, both domestically and internationally; it also actively promotes the consumption of whale meat within Japan. The Hogei-han has considerable influence over the Japanese media coverage in regard to whaling issues. Pelagic whaling expeditions receive extensive media coverage overseas but receive scant exposure at home. There was an exception to this when, as mentioned, a Japanese whaling vessel was reportedly attacked by the anti-whaling ship Sea Shepherd in Australian Antarctic waters in January 2008. In July of the previous year the IWC released information on the Japanese 2005-2006 scientific research season; that report was published in newspapers Australia-wide and in New Zealand. The press brought to the attention of readers the fact that 91 percent of the female whales killed were pregnant. ${ }^{66}$ The Humane Society International responded harshly to the report and there were numerous criticisms of the Japanese whaling action listed on the internet; however, a search by the author of the Japanese media failed to find any mention of the information or of any reaction to it. A further example of selective coverage is shown in the instance of a report prepared by a joint Australian/Japanese investigative panel for the Commission for the Conservation of Southern Bluefin Tuna, held at Miyazaki in October 2006. It found that over a long period, the volume caught by Japanese vessels was far more than the Fisheries Agency had admitted; Kyōdō News stated that "the findings were not made public". ${ }^{67}$ What can also be seen in relation to the whaling issue is that the government is not the only body to control information; the whaling lobby also influences that control. Danaher argued that "the fishing lobby exerts strong pressure on the government and on

\footnotetext{
${ }^{65}$ Whaling section, Fisheries Agency, Japan, http://www.jfa.maff.go.jp/whale/index.htm, (accessed 1 July 2007).

${ }^{66}$ Xavier La Canna, "Most of whale kill pregnant”, The Advertiser, 26 July 2007.

67 “Japan's excessive fishing of southern tuna detailed", Japan Times, 18 December 2006, p. 2.
} 
propaganda to the general public, and partly as a result, little anti-whaling sentiment surfaces among the general populace". ${ }^{68}$

The Hogei-han is able to allocate some of the MAFF's Official Development Assistance (ODA) to whaling issues. In 2007 the MAFF’s ODA budget was $¥ 4.8$ billion, 0.7 percent of Japan's total ODA budget; this was to be used for environmental, educational and technical areas of the MAFF. ${ }^{69}$ Japan is always looking at legal avenues within the IWC to support its aspirations and is able to exert pressure on developing countries who are IWC signatories, and who receive Japanese ODA. ${ }^{70}$ Danaher argued that Japan has given significant financial and technical aid to Caribbean countries and has encouraged them to join the IWC by paying their membership dues. ${ }^{71}$ Allegations of vote-buying by the use of Japanese ODA have given rise to controversy and have raised questions about the acceptability of the practice; the Hogei-han encourages bloc voting among some of the developing countries in order to support its position. The island of Saint Vincent, a member country of the IWC, has received large sums of money through Japan's ODA; the amount given increased from $\$ 50,000$ in 2001 to $\$ 7.7$ million in $2003,{ }^{72}$ Increased ODA to Saint Vincent during that period might just be a coincidence, but Japanese government officials have reportedly acknowledged using ODA to increase the number of participants in the IWC that endorse Japan's standpoint. According to Greenpeace Japan, in June 1999 the Deputy Minister for MAFF acknowledged that it was important to increase the number of countries in the IWC that support Japan. ${ }^{73}$ This confirms the belief that the MAFF uses ODA to influence voting. Morishita attempted to refute allegations over the misuse of ODA by saying that whilst Japan does not depend on military power or pressure from NonGovernmental Organizations (NGOs), the government endeavors to make its position understood by using foreign diplomacy and aid. ${ }^{74}$

\footnotetext{
${ }^{68}$ Danaher, "Why Japan will not give up whaling", Pacifica Review, p. 113.

${ }^{69}$ Nōrin suisanshō ODA yosan ni yoru torikumi (Ministry of Agriculture, Forestry and Fisheries, dealing with ODA budget ), http://www.maff.go.jp/kokusai/cooperation/02/pdf1/data02-1-2.pdf, (accessed 25 March 2008).

${ }^{70}$ Danaher, "Why Japan will not give up whaling", Pacifica Review, p. 108.

${ }^{71}$ Ibid., p. 108.

${ }^{72}$ The Ministry of Foreign Affairs, the government of Japan, 2005 http://www.mofa.go.jp/mofaj/area/svg/index.html, (accessed 15 September 2006).

${ }^{73}$ Greenpeace Japan, press release, 23 April 2002, http://www.greenpeace.or.jp/press/2002/20020423 html, (accessed 9 October 2006).

${ }_{74}$ J. Morishita, Naze Kujira wa zashou surunoka (Why are whales beaching?), Kawade Shobou Shinsha, Tokyo, 2002, p. 181.
} 
As the Hogei-han takes the lead in Japan's whaling policy, it is clear that the Japanese government views whaling issues as a fisheries matter, not an environmental one. In many Western countries, including Australia, whaling is considered an environment and resource matter. The Ministry of Environment (MOEN) in Japan does not have jurisdiction over whale hunting; it has responsibility in the areas of biodiversity and beached whales. Because of clear bureaucratic accountability in Japan, the Hogei-han is responsible to see that whales are to be used as a part of marine resources. The chief of that section, Morishita, emphasized that this was to be in a sustainable manner. ${ }^{75}$ The Hogei-han maintains a close partnership with the ICR in the whaling research, and with the JFA on fisheries issues.

\subsection{The Institute of Cetacean Research}

The ICR was established in October 1987 and is the sole institution responsible for Japan's scientific research whaling expeditions. The Nakabe Foundation of Whale Science was established as a private research institution in 1941. It was supplanted when Japan was permitted Antarctic whaling in 1946 by the Whales Research Institute; it was established in the following year as a non-profit organization (NPO) for research. ${ }^{76}$ Due to the whaling moratorium in 1987 it was reformed as the ICR but remained an NPO, specializing in whaling research under the MAFF. The ICR is a crucial player in policy formation as it has a central role with the other actors in the whaling chain (see Figure 2).

There are at least three features that determine the significance of the ICR and is particularly so since the commencement of Japan's scientific research whaling in 1987.

The first feature is the amount of financial assistance that the ICR receives from the Japanese government; operating under the umbrella of the Fisheries Agency, the ICR is given subsidies to conduct its research expeditions. In 2005 the Agency pledged financial

\footnotetext{
${ }^{75}$ Personal interview with Joji Morishita, December 2001 in Tokyo, Japan.

${ }^{76}$ Nihon Geirui Kenkyüjo (The Institute of Cetacean Research), Nihon geirui kenkyūsho no enkaku to setsuritsu mokuteki (History and establishment of the Institute of Cetacean Research), http://www.icrwhale.org/01-A.htm, (accessed 20 May 2009).
} 
backing of approximately $¥ 540$ million annually for the period 2006 to $2009 .^{77}$ Thus for that four-year period a total of around $¥ 2.2$ billion was planned to be spent on Japan’s whaling research program. The Fisheries Agency has an annual budget of around $¥ 250$ billion; however the subsidy of $¥ 540$ million was not allocated from the Agency’s budget but from the MAFF’s. The Agency’s 2009 budget reveals that $¥ 404$ million was allocated to whale resource research measures and $¥ 795$ million to smoothing the progress of the research project; this is a new budget allocation to prevent harassment or obstructions from anti-whaling groups. ${ }^{78}$ This reveals that the Agency is allocating more than $¥ 1$ billion to assist the ICR conduct the scientific research.

The second feature is the de facto relationship that the ICR had with Kyōdo Senpaku (shown in Figure 2) until 2006. Kyōdō Senpaku was established in 1987 to conduct whale research; it was a private company with around 300 employees. ${ }^{79}$ An important characteristic is that it is not an NPO; it was a profit motivated company. Kyōdo Senpaku was formally known as Kyōdō Hogei (Kyōdō Whaling) when it was involved in commercial whaling, and since the moratorium its vessels and personnel have been chartered by the ICR. Kyōdō Senpaku conducts the whale catch and the processing and selling of the meat from the expeditions, and until the change of ownership the previous cozy relationship with the ICR had continued for nearly twenty years.

The third feature involves Kyōdō Senpaku itself. Before 2006 the company shareholders were from Japanese fishing corporations. In March 2006 Kyōdō Senpaku announced a change of shareholding, from fishing companies to Kōeki hōjin (公益法人: 'public-interest corporations'. ${ }^{80}$ Aurelia Mulgan pointed out that these corporations are in essence "formally private, non-profit and non-commercial enterprises created by government". ${ }^{81}$ One reason for the change may well have been to reduce the target for criticism as previously its actions and profits had been challenged by anti-whaling groups. As Figure 2

\footnotetext{
${ }^{77}$ Ministry or Agriculture, Forestry and Fisheries, Geirui chōsa hokaku jigyōhi hojyokin (Subsidy for Cetacean research catch project), 2006 http://www.maff.go.jp/j/aid/hozyo/2006/suisan/pdf/21.pdf, (accessed 1 May 2008).

${ }^{78}$ Ministry of Agriculture, Forestry and Fisheries, the Fisheries Agency, Heisei 21 nendo suisan yosan gaisan kettei no gaiyō (The Fisheries detailed budget for 2009), December 2008, http://www.jfa.maff.go.jp/j/budget/pdf/21kettei.pdf, (accessed 20 May 2009).

${ }^{79}$ Haiyaku (Players), http://luna.pos.to/whale/ipn bio play.html, (accessed 27 July 2007).

${ }^{80}$ Kyōdō Senpaku Kaisha Ltd., "Changes in the shareholder composition", 24 March 2006, http://www.icrwhale.org/eng/060324news.pdf, (accessed 12 May 2008).

${ }^{81}$ A. Mulgan, The politics of agriculture in Japan, Routledge, London, 2000, p. 116.
} 
shows, the three main shareholders (A, B, and C) are companies that had previously been engaged in pelagic whaling. Nissui, Kyokuyō and Taiyō (renamed Maruha in 1993) each had a 32 percent share, and three former coastal whaling companies had a combined holding of 4 percent. ${ }^{82}$ The major shareholders were not just simple fishing companies but are a part of a huge network of businesses. To give an idea of the scale, in 2008 the parent company Kyokuyō had sales of $¥ 35$ billion and its chain of affiliated companies had total sales of $¥ 148$ billion. ${ }^{83}$ This leaves no doubt that commercial interests are firmly behind research whaling. Scott Baker pointed out the close collaboration between the ICR and fishing interests through Kyōdo Senpaku as the crews and vessels involved in the research expeditions were previously engaged in commercial whaling. ${ }^{84}$

The subsidies to the Institute, its relationship with Kyōdo Senpaku, and its indirect relationship with major Japanese fishing corporations, indicate that the ICR's research program is shaped by Japanese commercial fishing interests.

\subsection{Dai Nippon Suisan Kai (Japan Fisheries Association)}

The literal translation of Dai Nippon Suisan Kai is 'Greater Japan Fisheries Association' (JFA). The JFA was established as far back as 1882 and is the sole institution that acts as an umbrella over the entire fishing industry. The JFA is the largest organization working for the betterment of the fisheries industry in Japan, whereas Nippon Keidanren is the largest organization that works for business growth in industry and manufacturing. The JFA has more than 400 members that comprise individuals, companies, and organizations; it is financed by annual membership fees which in the 2006-2007 financial year totalled approximately $¥ 150$ million. $^{85}$

In the whaling debate very little attention has been given to the role of the JFA. It is more than just a collection of fisheries' groups; it is a major organization that exerts considerable

\footnotetext{
${ }^{82}$ Haiyaku (Players), http://www.luna.pos.to/whale/ipn bio play.html, (accessed 27 July 2007).

${ }^{83}$ Kyokuyo Co. Ltd., IR jyōhō (IR information), http://www.kyokuyo.co.jp/ir/result.html, (accessed 6 May 2008).

${ }^{84}$ Baker and Clapham, “Appendix 1: Ethics of scientific whaling: issues and alternatives", Science, profit and politics: scientific whaling in the $21^{\text {st }}$ Century, p. 30 .

${ }^{85}$ Dai nihon suisan kai (Japan Fisheries Association), http://www.suisankai.or.jp/daisui/zaimu/pdf/h18 report 3.pdf, (6 May 2008).
} 
influence on those players who determine Japan's whaling policy. The JFA strongly supports Japan's scientific research whaling in the expectation that it will lead to a resumption of commercial whaling. A reason for its power is the close connection that the JFA has with Japanese politicians; for example the Liberal Democratic Party (LDP) has a close interest in fisheries affairs and the Association gives the LDP considerable financial support. As a result of the alliance, the JFA is a significant power in the political arena.

Four features illustrate the significance of JFA's position in relation to the whaling policy. The first is its long history with Japanese fishing interests. The Association was established during the Meiji period (1868-1912) and has had a very close connection with the Japanese Imperial Household; Prince Akihito Komatsunomiya was the first president of the JFA when it was inaugurated in $1882 .{ }^{86}$ In the Meiji government the Emperor had sovereign power over policy formulation in Japan and as there was no government institution to deal with fisheries issues, the JFA became the sole policy-making body. Under the supervision of the Imperial Parliament it had a major role in the politics of the fishing industry: it acted for and was committed to the betterment of Japanese fisheries. The Association achieved a notable success in 1895 when it submitted a Fisheries Bill to the Imperial Parliament; as a result in 1901 the Fisheries Law was enacted. ${ }^{87}$ The passing of this bill showed that the JFA was the leading institution in fisheries matters and that it acted on behalf of the Imperial government. The JFA continued to direct key policy decisions for the Japanese fishing industry until 1948.

The second feature was the establishment of the Fisheries Agency of Japan in 1948 as in postwar Japan the political structure changed from imperial rule to a democratic government. Even though the JFA virtually lost the power to make policies directly, it continued to exert behind the scenes influence. The Association applies pressure on the Fisheries Agency in order to accomplish favorable outcomes for the fishing industry. The power politics of the Association have not much changed since its inception. An example of that is shown when in December 1965 the JFA made a private arrangement with the National Federation of Fisheries Cooperative of the Republic of Korea. The backdrop to this was that in 1965 , due to social and political pressure, a diplomatic relationship was

\footnotetext{
${ }^{86}$ Dai Nippon suisan kai (Japan Fisheries Association), Rekishi (History: Meiji-Heisei), http://www.suisankai.or.jp/daisui/rekishi1.html, (accessed 8 August 2007).

${ }^{87}$ Dai Nippon suisan kai (Japan Fisheries Association), Rekishi (History: Meiji-Heisei).
} 
established between Japan and the Republic of Korea. The arrangement led to the Fisheries Agency signing two treaties between Japan and the Korean Republic: the Basic Treaty and the Fishery Treaty. ${ }^{88}$ The Japan/Korean fisheries treaties were for growth and mutual cooperation. Furthermore, the JFA presents the point of view of the fishing industry and then requests the Fisheries Agency to then take the necessary measures. ${ }^{89}$ The JFA is dedicated to exerting pressure on the Agency in order to accommodate the needs of its industry.

The third feature was the establishment of the ICR in 1987. Due to the decision by the IWC to impose a moratorium on commercial whaling from 1987, the JFA made a farreaching and astute move to keep its whaling operations alive. According to JFA sources, in August 1987 the JFA requested the Fisheries Agency to establish a fund for whale research. As a result of the campaigning the Agency established the non-profit ICR in October of the same year. ${ }^{90}$ This is a further example of the often unseen influence wielded by the JFA over the Fisheries Agency.

The JFA umbrella also covers whaling interests, although at the present time there are no large-scale whaling operations. The JFA seeks to resume commercial whaling and with it the associated increase in fisheries activity. The Association influences the government fisheries policy and particularly Japan's scientific research whaling policy; since the moratorium this has virtually been Japan's whaling policy. One reason for the ability of the JFA to exert influence is that it operates under the Japanese Amakudari (Parachuting) system. The Amakudari scheme in Japan is a common practice whereby retired senior government bureaucrats go to high profile positions in private or public institutions. Aurelia Mulgan pointed out that the "the amakudari bureaucrats can be as influential as politicians in influencing the ministry to outlay subsidies to their group"; 91 this is particularly significant when it come to budget allocations. Mulgan further stated that the parallel nature of the gaikaku daintai (外郭団体: statutory and institutional interest groups) and the ministry bureaus which "have a direct line of communication into the initial draft of budgetary demands within the bureaus". ${ }^{92}$ Because of previous contacts, an

\footnotetext{
${ }^{88}$ Dai Nippon suisan kai (Japan Fisheries Association), Rekishi (History: Meiji-Heisei).

${ }^{89}$ Ibid.

${ }^{90}$ Ibid.

${ }^{91}$ Mulgan, The politics of agriculture in Japan, p. 513.

92 Ibid., p. 513.
} 
ex-Director General of a MAFF bureau makes for a very effective leader; ${ }^{93}$ this is seen in the JFA structure. The chairperson is Isao Nakasu, the former Director General of the Fisheries Agency in the MAFF, two vice chairpersons and a director are from the three previous major shareholder companies of Kyōdō Senpaku, and Kyōdō Senpaku's managing director is also a director from within the JFA. ${ }^{94}$ The amicable relationship between high profile JFA executives and the government has a significant effect on ICR affairs.

Hirata claimed that the Japanese business sector is excluded from the bureaucratic decision-making process and that business involvement in shaping Japan's whaling policy is very minor. ${ }^{95}$ However, he fails to acknowledge the considerable power of the Japanese fisheries industry through its representative, the JFA. Japanese industry, particularly through associations and organizations such as Keidanren and the JFA, exerts an enormous amount of influence on bureaucratic policy-making.

The fourth element is the annual payments that the JFA receives from the Fisheries Agency for projects such as the promotion, the preservation, and the support of the fishing industry. In the financial year 2007-2008, the JFA received about $¥ 16$ billion in subsidies from the Japanese government. ${ }^{96}$ This enormous sum shows the depth of involvement of the JFA in fisheries affairs and its influence in the policy making. The JFA appears at times to be as powerful as the Fisheries Agency itself and its voice can often be heard in the international diplomatic field. To give an example, Australian territorial waters are extremely important to the Japanese Southern bluefin tuna industry and in 1989 there was a confrontation between Japan and Australia regarding those resources. Masayuki Komatsu, who represented the Japanese government, believed that the Australian Prime Minister, Bob Hawke, was about to impose a moratorium on tuna caught within the Australian 200 nautical mile boundary. ${ }^{97}$ The proposed moratorium was the result of pressure from Australian environmentalists who wanted their government to exercise resource management over tuna as well as over whales. The proposal was to reduce quotas by 66

\footnotetext{
${ }^{93}$ Mulgan, The politics of agriculture in Japan, p. 513.

${ }^{94}$ Dai Nippon suisan kai (Japan Fisheries Association) Yakuin meibo (Member's directory) as at July 2007, http://www.suisankai.or.jp/daisui/zaimu/new pdf/yakuin.pdf, (accessed 6 May 2008).

${ }^{95}$ Hirata, "Beached whales: Examining Japan's rejection of an international norm”, p. 16.

${ }^{96}$ Dai Nippon suisan kai (Japan Fisheries Association), Financial report between April 2007- March 2008, http://www.suisankai.or.jp/daisui/zaimu/pdf/h19 plan 2.pdf, (accessed 7 May 2008).

${ }_{97}$ Komatsu, M. and Endō, H., Kokusai maguro saiban (International tribunal for Southern Bluefin Tuna), Iwanami shoten, Tokyo, 2002, p. 102.
} 
percent; this would have had an adverse effect on the Japanese fishing industry. ${ }^{98}$ The JFA and six other Japanese organizations believed that it was a political decision and protested directly to the Australian Prime Minister. ${ }^{99}$ The Fisheries Agency was then compelled to give financial assistance to those fishermen who were forced to reduce boat numbers in international waters. ${ }^{100}$ The JFA has continued actively to commit itself, both diplomatically and politically, to promoting the interests of the large Japanese fishing corporations.

\section{The domestic whaling strategy}

While the Japanese government has taken a strategic approach through the use of scientific evidence to justify its stance to the IWC members, the Hogei-han in the Fisheries Agency and the ICR have embarked on a direct approach to the Japanese public. They have collaborated on promoting the impression that the practice of eating whale meat is a cultural issue. The Hogei-han wanted to increase the domestic consumption of whale meat and used the nationalistic sentiment on whaling to give support to the government policy. Danaher pointed out that the Fisheries Agency expanded the whaling issue into one that crosses over into culture, national pride, food security, and sovereignty. ${ }^{101}$ The domestic initiatives have not drawn as much criticism or publicity as has the scientific research program, but neither have resulted in a resumption of commercial whaling, an aim to which Japan's pro-whaling lobby is committed.

Prior to the 1930s whale meat was eaten only in a few coastal communities and it was over the following 50 years that the practice could be said to have been widely practiced. The acute food shortage during this period meant that one option available to the Japanese government to provide its populace with sufficient protein in their diet was through the consumption of whale meat, an option that was encouraged by the occupying forces from 1945. However, the situation today is completely different. With a plentiful and varied supply of food readily available to the Japanese public, the concern of the Japanese

\footnotetext{
${ }^{98}$ Komatsu and Endō, Kokusai maguro saiban (International tribunal for Southern Bluefin Tuna), p. 102.

${ }^{99}$ Dai Nippon suisan kai (Japan Fisheries Association), Rekishi (History: Meiji-Heisei).

${ }^{100}$ Ibid.

${ }^{101}$ Danaher, "Why Japan will not give up whaling", Pacifica Review,p. 116.
} 
government and the Fisheries Agency is not so much the health of citizens, but rather the health and well-being of the Agency itself. The Agency sponsors the Japanese whaling industry through the close relationship of its bureaucrats and the fishing industry. The well-being of the Agency relies on a profitable domestic enterprise.

There are at least three approaches that the Fisheries Agency and the ICR have taken to promote whale meat consumption in Japan. The first was the establishment of a company named Geishoku Labo. The primary purpose of the company was to establish new markets and to optimize the use of the whale meat harvested by the scientific research expeditions. ${ }^{102}$ The meat is not only made available through commercial outlets but is also supplied for use in public institutions, such as for lunches in hospitals. Figure 2 shows the position of the company that was founded by the Fisheries Agency and the ICR in May 2006; it was to be for a period of five years until 2010. ${ }^{103}$ As it operates under the Fisheries Agency and the ICR, Geishoku Labo is able to set the annual amount of whalemeat sold and the market price. ${ }^{104}$ The company was established with the aim of stimulating and strengthening the whale meat market; this is another illustration of the determination of the Fisheries Agency. This company is a market-oriented business enterprise based on the produce from the whaling research; it is not merely a low-profile research organization.

After a break of 11 years, the government decided in 2002 to resume importing whale meat from Norway. It did so in order to stimulate the domestic market. ${ }^{105}$ Three years later, in 2005, Japan's scientific research fleet increased its catch to 1,243 whales, up from 755 the previous year (refer Table 2). The increased whale catch since 2005, and the establishment of Geishoku Labo in 2006, is no coincidence. The Fisheries Agency wanted to increase domestic whale meat consumption and consequently to strengthen the foundation of the industry.

The second approach was to wage several campaigns in order to educate both adults and school-aged children into a routine of eating whale meat. The ICR organized classes such

\footnotetext{
${ }^{102}$ Geishoku Labo, http://www.gishoku-labo.co.jp/labo 1.html, (accessed 5 July 2007).

${ }^{103}$ Ibid.

${ }^{104}$ Ibid.

105 "Whale meat imports to resume", The Asahi Shimbun, 6 March 2002,

http://www.asahi.com/english/national/K2002030600706.html, (accessed 6 March 2002).
} 
as 'Kujira ni tsuite manabō (Let's learn about the whales)' for children in primary schools in order to familiarize them with whales and whaling. These campaigns are only conducted in the eight prefectures, and in Hokkaido, where there has previously been a whaling culture. The ICR also conducts 'whale-cooking' classes for adults in several regional areas, and through chef technical schools around Japan. There are about 13 schools such as Hattori Nourishment Technical School in Tokyo and Kyushu Bunka Gakuen College of Cooking in Nagasaki prefecture. ${ }^{106}$ These technical school campaigns are aimed at high school graduates in an endeavor to re-establish the culture of eating whale meat. Japan's pro-whaling groups such as the government and the fishing industry are afraid that the cultural importance of eating whale meat will fade away.

The coalition actively promotes the culture by using whale meat in school lunches, mainly in primary and junior high public schools; in 2004 14,000 such lunches were prepared for students in 39 schools in Kushiro city, Hokkaido. ${ }^{107}$ In addition, it was served in 195 schools in Wakayama prefecture, in 115 schools in Nagasaki City, and elsewhere. The aim of providing the lunches is not only to promote it as a food but also to educate young people's tastes in an attempt to encourage the habit. Soon after World War II whale meat was considered everyday food; now however it is considered as something special or different. In 1962 Japan experienced its highest ever commercial harvest of whales with a catch of about 226,000 tons of meat. In comparison to the 1962 catch, the 2006 harvest of 5,500 tons pales into insignificance. Whale meat is only available in specialty shops and restaurants: it is no longer everyday food in Japan. Kyōdo Senpaku is considering closing its Yushin restaurant that specializes in whale meat as it continues to lose money. ${ }^{108}$ In addition, fishing companies have reacted to threats by foreign customer boycotts by disposing of their shares in Kyōdo Senpaku. By September 2008, the stockpile of frozen whale meat in Japan had exceeded 4000 tons. ${ }^{109}$

The third approach to counter whaling opponents is to use the cultural aspect of whaling to create a sense of countrywide unity within Japan. A strong emphasis on the cultural

\footnotetext{
${ }^{106}$ Oishii kujira kyōshitsu (Delicious whale meat cooking class), http://www.e-kujira.or.jp/topic/edu/06/0210/index.html, (accessed 16 April 2008).

${ }_{107}$ Gakkō Kyūshoku 50 nen (School lunch for 50 years), Yomiuri Shimbun On-line, 5 November 2004, http://www.yomiuri.co.jp/kyoiku/special/s01/20041105tv01.htm, (accessed 11 July 2007). 108 Japanese whalers go with no guard, The Weekend Australian, November 15-16, 2007, p. 16. 109 Ibid.
} 
significance encourages a patriotic sentiment among the public. With the slogan 'Whaling is our culture' the Fisheries Agency has attempted to sponsor a revival of the custom through Japanese identity, food culture, cultural values, and religious aspects, all very nationalistic. There is no doubt that cultural differences are contributors to the disagreement between those in favor of whaling and those opposed to it. Hirata said that the Japanese public, and especially its leaders, consider the whaling disagreement to be largely a matter of cultural differences. ${ }^{110}$ Morishita, for example, argued that the nature of the whaling dispute is a cultural and ethical conflict between countries that view whales as a food resource, and countries that view whales as something special. ${ }^{111}$ Is the Agency promoting a tradition of eating whale meat, or a tradition of harvesting whales? It can be said that eating whale meat was a national practice for only 50 years although some fishermen still continue with coastal whaling, the authenticity and continuity of that tradition is diminishing.

Japan's small-scale coastal whaling has a long tradition and where it has been practiced it has a cultural significance. A reminder of that tradition is seen in the Taichi region of Wakayama prefecture where people have family names relating to whaling such as Tömi (person who finds whales), Amino (person who puts out nets), and Yutani (person who squeezes oil). ${ }^{112}$ However, that tradition currently exists only in the whaling ports of Ayukawa in Miyagi prefecture, Wada in Chiba prefecture, Taichi in Wakayama prefecture, and Abashiri and Hakodate in Hokkaido. Whaling is traditional and important in those locations, but it can hardly be called a national tradition. ${ }^{113}$ This claim by the Fisheries Agency misrepresents the facts. Kalland and Moeran pointed out that the whaling issue serves to draw attention to the much cherished myths of Nihonjinron (Japaneseness, discussed in Chapter one), and thus aligns itself with an inference of nationalism. ${ }^{114}$ The feeling of Nihonjinron among the Japanese comes from a combination of identity, ideological, and cultural behavior. Many Japanese people today consider that they have

\footnotetext{
${ }^{110}$ Hirata, “Beached whales: Examining Japan's rejection of an international norm”, Social Science Japan Journal, p. 11.

${ }^{111}$ Morishita, "Hogei mondai no rekishiteki nenyō to shōrai no tenbō (Historical transition of the whaling issue and its future: an analytical approach by a matrix)", p. 1.

${ }^{112}$ Ima kujira no minato wa (What about whaling towns now?), Osakana Tsūshin; Gyo (Fish correspondence; Fish), 2001, p. 22.

113 "Whaling in Japan, local flukes", The Economist, 14 July 2007, p. 30.

${ }^{114}$ Kalland and Moeran, Japanese whaling, end of an era?, p. 195.
} 
distinctive characteristics that are unique to them, and the whaling debate re-enforces that concept of Nihonjinron.

Dannaher also made the point that the Fisheries Agency has injected the spirit of patriotism into the whaling debate; ${ }^{115}$ national culture is being used as an instrument by Japanese bureaucrats and politicians. Politicians, mainly from the ruling LDP, formed a lobby named Jimintō hogei giin renmei (parliamentarian whaling lobby) to support Japan's whaling industry. The lobby was established by nearly 100 LDP members in order to support Japan whenever it deals with whaling issues. David McNeill pointed out that the members of the whaling lobby included former Prime Ministers Tarō Asō and Shinzo Abe, and many other LDP parliamentarians. ${ }^{116}$ However, whaling issues attract members from other parties and this is seen in the traditional whaling prefecture of Yamaguchi prefecture. The prefectural government has 49 parliamentarians who have formed a lobby named hogei giin renmei to protect the traditional culture. ${ }^{117}$ The local government view is also often expressed; in the 2004 Nihon Keizai Shinbum the mayor of Yokohama, Hiroshi Nakata, argued strongly for Japan's right to conduct whaling. ${ }^{118}$ The lobby works closely with government bureaucrats, principally with those within the Fisheries Agency to promote and support Japan's whaling ambitions. Even though the lobby does not have a great deal of direct political power over whaling matters, its work in the background has been influential in shaping domestic attitudes towards whaling; the parliamentarians are the voice for their region's pro-whaling constituent groups.

\section{Question of the ethics of Japan's whaling policy}

Since the 1987 moratorium, the direction of Japan's whaling policy has been largely directed by, and dependent on, the scientific research program. This raises a number of ethical and philosophical concerns as the policy fails to properly recognize the element of

\footnotetext{
115 Danaher, "Why Japan will not give up whaling”, Pacifica Review, p. 120.

${ }^{116}$ D. McNeill, "Japan and the whaling ban: siege mentality fuels 'sustainability' claims", Japan focus and Asia-Pacific e-journal, 13 February 2007, http://www.japanfocus.org/products/details/2353, (accessed 5 March 2008).

${ }^{117}$ Hogei bunka mamore, chihō gikai mo kokkai mo chōtōha de icchi danketsu (Protect the whaling tradition, local governments collaborate with the central government), Asahi Shimbun, 5 July 2008, http://www.asahi.com/food/news/SEB200807050015.html, (accessed 21 May 2009).

${ }^{118}$ H. Nakata “'Hogei' dōdō to taigi wo katare ('Whaling' seeks justice with dignity"), Nihon Keizai Shimbun, 5 July 2004, p. 5.
} 
sustainability; it is an ethical component required in resource management (discussed in Chapter 2). Furthermore, the policy blurs the distinction between scientific whaling and commercial whaling. This section first questions the ethics of Japan's research whaling program, and then assesses the integrity of the distribution of the revenue generated by the program among associated groups.

\subsection{The ethics of scientific whaling}

The Fisheries Agency clearly states that sustainable development is the philosophy behind Japan's whaling policy and it appears that the same ethos applies to its scientific research program. The Japanese government has consistently maintained that sustainable development is the key premise, but there is a weakness in that argument. As Sharon Beder states, sustainable development aims to achieve economic growth; ${ }^{19}$ this type of growth does not guarantee environmental sustainability. The Japanese notion of sustainable development within whaling would entail the 'sustainable harvesting' of marine resources. The Japanese whaling policy espouses the principle of sustainable harvesting with maximum sustainable yield (MSY); but Danaher questions this maxim. He argues that optimum use does not necessarily lead to sustainable use; it can put whale species at the risk of becoming endangered. ${ }^{120}$ For example, the maximum sustainable yield can be exceeded before the whalers are aware of it with disastrous consequences. Growth has become a modern ideal but it cannot be sustained indefinitely. Herman Daly stated that the ethical principle of sustainable development encompasses sustainability, sufficiency, equity, and efficiency, of which the goal is sufficient, not maximum. ${ }^{121}$ Daly judged that the economic system must not overlook the ecosystem to the point of lessening future life. ${ }^{122}$

In spite of conducting whaling under the flag of 'scientific research', Japan's central philosophy of maximizing sustainable use has changed little. The core ethic of sustainable development means that if whaling is to be allowed, then the whale resource needs to be sustained indefinitely for the benefit of future generations.

\footnotetext{
${ }^{119}$ S. Beder, Environmental principles and policies: an interdisciplinary approach, University of New South Wales Press Ltd., Sydney, 2006, p. 19.

${ }^{120}$ Danaher, "Why Japan will not give up whaling", Pacifica Review, p. 108.

${ }^{121} \mathrm{H}$. Daly, Beyond growth, the economics of sustainable development, Beacon Press, Boston, 1996, p. 220.

122 Ibid., p. 223.
} 
From the perspective of environmental ethics it is hard to see how Japan's research program can be justified. The practice of hunting whales and Japan's questionable research are often condemned in debates and writings; what is needed in a challenge to the policy and its practices is a philosophical perspective. The characteristics of whales as a marine mammal and as a marine resource attract varied critical views from multidisciplinary areas. Even though environmental philosophers view the whaling issue through different lenses, their fundamental conclusions are not dissimilar. Ethical concerns about Japan's whaling policy will be looked at from four viewpoints.

The philosopher Alastair Gunn, speaking on the various aspects of hunting, raised the concern that the practice causes suffering. There is no 'humane' method of slaughter; killing is killing and those whales that are harpooned usually suffer an agonizing death. ${ }^{123}$ Tom Regan, an advocate for animal rights, strongly believes in an ethical respect towards animals. He argues that it is fundamentally wrong to allow humans to view animals as 'our resources', available for humans to be eaten and exploited for money or for sport. ${ }^{124}$ Regan strongly condemns the use of any animals, be it whales or others, for scientific and commercial exploitation. Clare Palmer states that the contentious issue of hunting animals should be viewed from the perspective not so much on "the ethical unacceptability of taking life but rather on the ethical unacceptability of causing suffering". ${ }^{25}$ The Japanese government's policy fails from a Western environmental ethics point of view; it also fails from what the Japanese would consider an ethical attitude towards whales and whaling. Traditionally the Japanese have related to nature in a cooperative and harmonious manner (discussed in Chapter 2). This applies to whalers who, although they killed whales, also showed great respect towards them. This can be observed at whale festivals held in Japan. Keiji Nasu pointed out that there is a belief among villagers that whales are the god of fisheries; they bring food and fortune to them, and in return they honour the whales with festivals. ${ }^{126}$ The government whaling policy does not show a similar attitude.

\footnotetext{
${ }^{123}$ A. Gunn, "Environmental ethics and trophy hunting", Ethics and Environment, vol. 6, no. 1, 2001, p. 70.

${ }^{124}$ T. Regan, "The case for animal rights" in S. Cahn and P. Markie, Ethics, history, theory, and contemporary issues, (2 ${ }^{\text {nd }}$ edition), Oxford University Press, Oxford, 2002, p. 825.

${ }^{125}$ C. Palmer, Environmental Ethics, Contemporary ethical issues, ABC-CLIO, Inc., California, 1997, p. 78.

${ }^{126}$ Nasu, Hogei seisuiki (The story of whaling's rise and fall), p. 135.
} 
The ethics of the research program needs to be looked at from a scientific point of view as most environmental philosophers, ethicists and scientists believe that ethics is an important element of scientific research. Gillespie argues that ethics is entwined with science, especially when using animals for scientific purposes. ${ }^{127}$ When it comes to whaling issues, the general public would expect the IWC and the ICR to advocate ethics in any scientific research. It is important to note that neither of these two bodies has an 'Ethics Committee'. Jon Nevill pointed out that scientists frequently do not raise ethical issues in their research, but instead they rely on scientific theories, models, and data. ${ }^{128}$ Failure to address the importance of ethics in whaling research could well result in, or reflect, a disregard for the value of the species and their contribution to their marine environment. Science and ethics are partners, science to provide new knowledge, and ethics to assess professional conduct in order to define the problem to be solved. With Japan's scientific whaling the question arises as to whether the program creates dilemmas rather than providing an understanding of whale biology and other scientific information. Over the past two decades Japan's program has killed more than 10,000 whales (refer Table 2) but appears to have provided very little valuable data on whale ecology. Of the 150 so called 'publications' listed by the ICR, Baker claims that only one can be considered to have dealt with the requirements of the IWC, and to have been published in a peer-reviewed international journal. ${ }^{129}$ Baker makes the further point that "the financial incentives of scientific whaling and the participation of staff scientists from the funded institute in the scientific advice given for management within the IWC Scientific Committee, creates the potential for considerable conflict of interest". ${ }^{130}$

The results of Japan's research have not yet been sufficiently convincing to gain the approval of the IWC members to allow a resumption of commercial whaling. However, the Japanese government wants to prioritize its research evidence in order to justify the continuation of the program. Their slogan 'science is on our side' explains this mindset; science is used as justification for the government to continue the contentious research which annually claims around 1,000 (mainly minke) whales (see Table 2).

\footnotetext{
${ }^{127}$ Gillespie, "Whaling under a scientific auspice: the ethics of scientific research whaling operations", Journal of International Wildlife Law \& Policy, p. 34.

${ }_{128}$ J. Nevill, Ethics, fisheries, and marine protected areas, Working draft paper, 26 June 2006, p. 4.

${ }^{129}$ Baker and Clapham, "Appendix 1: Ethics of scientific whaling: issues and alternatives", Science, profit and politics: scientific whaling in the $21^{\text {st }}$ Century, p. 32 .

${ }^{130}$ Ibid., p. 30.
} 


\subsection{The Whaling Triangle - distribution network}

The morality of the distribution route for the proceeds of the 'research whale products' within Japan's whaling triangle can be called into question. The delivery network has received little attention from scholars and few of its activities have been made public. The research program delivers financial benefits to selected whaling interest groups; three features will be examined in order to determine the integrity of the arrangement.

The first is the relationship between the ICR and Kyōdo Senpaku. When it was a private company, Kyodō Senpaku had been commissioned by the ICR to supply the research expedition vessels; during the period from 1990 to 1991 it received $¥ 2$ billion for vessel hire and for commissions on by-product sales. ${ }^{131}$ After the change of ownership, the ICR's Assets Detail Report of 2007 listed Kyōdo Senpaku as a part of its fixed assets with a value of $¥ 289$ million. $^{132}$ As mentioned, there are other public institutions that also have shares in the company.

The second feature to be examined is the financial implications of the hire of charter vessels used in the research expeditions. The ICR's financial report of 30 September 2007 showed liabilities on vessel hire at $¥ 860$ million. ${ }^{133}$ The ICR used to pay the hiring fee to Kyōdo Senpaku until the change of ownership and it is unclear from the report to whom the amount of $¥ 860$ million is owed. There is no doubt that a fee needs to be paid, but there seems to be a lack of transparency regarding the recipients of those fees.

The third feature is the question of the profits that are generated from the research program. The ICR is the central organization that supplies and manages the expeditions, as it has over the last two decades. Looking through the ICR's revenue and expenditure report for the financial year 1 October 2006 to 30 September 2007, the combined income from subsidies and sales of whale products exceeded operating costs. Income was roughly $¥ 7.8$

\footnotetext{
${ }^{131}$ Shikin no nagare (money flows), http://luna.pos.to/whale/ipn bio money.html, (accessed 6 August 2007).

${ }^{132}$ Nihon Geirei Kenkyüjo (The Institute for Cetacean Research) Zaisan Mokuroku (Assets Details) as at 30 September 2007, data available at: http://www.icrwhale.org/H 18jigyo.pdf, (accessed 12 May 2008).

${ }^{133}$ Ibid.
} 
billion (US\$78 million), whilst expenditure was $¥ 830$ million (US\$8.3 million). ${ }^{134}$ Table 1 lists the expedition Income and Expenditure report for 2006/7.

Table 1: ICR income and expenditure for scientific research whaling during the period $1 / 10 / 2006-30 / 09 / 2007$.

\begin{tabular}{|l|r|l|r|}
\hline \multicolumn{2}{|c|}{ Income } & \multicolumn{2}{c|}{ Expenditure } \\
\hline By-product income & $6,838,913,000$ & Investigation and research & $135,187,000$ \\
\hline Government subsidy & $537,782,000$ & Management and supply & $12,870,000$ \\
\hline Research re-imbursement & $407,768,000$ & International investigations & $78,370,000$ \\
\hline Operational re-imbursement & 847,000 & Public relations activities & $601,980,000$ \\
\hline DNA registration income & $16,000,000$ & & \\
\hline & & & \\
Total & $¥ 7,801,310,000$ & Total & $¥ 828,407,000$ \\
\hline
\end{tabular}

Source: The Institute for Cetacean Research, Compiled by the author

The report shows a book profit of about $¥ 7$ billion. That the research program is highly valued within whaling interests and by the government is shown by the annual subsidy of about $¥ 500$ million (US\$5 million) from the Fisheries Agency of the MAFF. The significance of the amount is seen when that subsidy is compared to what Japan's fishing village regions received in 2008 . They were only allocated $¥ 103$ million from the agency to subsidize a project named Gyoson chiiki ryoku kōjō jigyō (Project for the revitalization of regional fishing). ${ }^{135}$ The growth industry of Pacific bluefin tuna aquaculture, designed to provide a sustainable supply of that fish, only received $¥ 247$ million, ${ }^{136}$ an amount half of that which was given to the whaling research program.

\footnotetext{
${ }^{134}$ Nihon Geirui Kenkyüjo (The Institute for Cetacean Research) 2006 Revenue and expenditure report, data available: http://www.icrwhale.org/H18sushi.pdf, (accessed 12 May 2008).

${ }^{135}$ The Ministry of Agriculture, Forestry and Fisheries Japan, Gyoseon chiiki ryoku kōjyō jigyō (Project for the revitalization of regional fishing) by Fisheries Agency, 2008, http://www.maff.go.jp/j/aid/hozyo/2008/suisan/pdf/25.pdf, (accessed 21 May 2008).

${ }^{136} \mathrm{Ibid}$. , http://www.maff.go.jp/j/aid/hozyo/2008/suisan/pdf/06.pdf, (accessed 21 May 2008).
} 
Table 2: Japan's special permit catches from 1987 to 2006

\begin{tabular}{|c|r|r|r|r|r|r|r|}
\hline Year & \multicolumn{1}{|c|}{ Fin } & \multicolumn{1}{|c|}{ Sperm } & \multicolumn{1}{|c|}{ Sei } & \multicolumn{1}{c|}{ Brydes } & \multicolumn{1}{c|}{ SH } & NP & \multicolumn{1}{c|}{ Total } \\
\hline 1987 & 0 & 0 & 0 & 0 & 273 & 0 & 273 \\
\hline 1988 & 0 & 0 & 0 & 0 & 241 & 0 & 241 \\
\hline 1989 & 0 & 0 & 0 & 0 & 330 & 0 & 330 \\
\hline 1990 & 0 & 0 & 0 & 0 & 327 & 0 & 327 \\
\hline 1991 & 0 & 0 & 0 & 0 & 288 & 0 & 288 \\
\hline 1992 & 0 & 0 & 0 & 0 & 330 & 0 & 330 \\
\hline 1993 & 0 & 0 & 0 & 0 & 330 & 0 & 330 \\
\hline 1994 & 0 & 0 & 0 & 0 & 330 & 21 & 351 \\
\hline 1995 & 0 & 0 & 0 & 0 & 440 & 100 & 540 \\
\hline 1996 & 0 & 0 & 0 & 0 & 440 & 77 & 517 \\
\hline 1997 & 0 & 0 & 0 & 0 & 438 & 100 & 538 \\
\hline 1998 & 0 & 0 & 0 & 1 & 389 & 100 & 490 \\
\hline 1999 & 0 & 0 & 0 & 0 & 439 & 100 & 539 \\
\hline 2000 & 0 & 5 & 0 & 43 & 440 & 40 & 528 \\
\hline 2001 & 0 & 8 & 1 & 50 & 440 & 100 & 599 \\
\hline 2002 & 0 & 5 & 40 & 50 & 441 & 152 & 688 \\
\hline 2003 & 0 & 10 & 50 & 50 & 443 & 151 & 704 \\
\hline 2004 & 0 & 3 & 100 & 51 & 441 & 160 & 755 \\
\hline 2005 & $10 *$ & 5 & 100 & 50 & 856 & 222 & 1243 \\
\hline 2006 & 3 & 6 & 101 & 51 & 508 & 197 & 856 \\
\hline
\end{tabular}

Source: Special Permit catches, International Whaling Commission. ${ }^{137}$ Compiled by the author

* Note: SH (Southern Hemisphere) and NP (North Pacific)

* The population of fin whales was uncertain so the IWC placed them under protection status. http://www.iwcoffice.org/_documents/table_permit.htm

\section{Conclusion}

Since the moratorium on commercial whaling, the heart of Japan's whaling policy has been its scientific research whaling program with the government's aim of seeing a resumption of the practice. Whaling is extremely contentious as it raises concerns of cultural, political, socio-economic, and environmental matters with some critics who claim that the policy fails to acknowledge the significant ecological value of the whale species and that it fails to ensure the sustainability of the marine resource. Japan's whaling policy is built on the premise that whales are a resource to be utilized; this objective is strongly influenced and

\footnotetext{
${ }^{137}$ http://www.iwcoffice.org/ documents/table permit.htm, (accessed 28 August 2006)
} 
directed by the Whaling Triangle. Although the policy endorses sustainable development, its primary purpose is to cater to vested interests.

The Japanese government seeks legal justification under the IWC for its scientific program whilst at the same time the Triangle attempts to gain public support on whaling issues. The government spends large sums of money from the public purse on whaling matters but little benefit goes to the general community. Whether commercial whaling is resumed or not, the beneficiaries of the tax payer funded research program remain the associated fisheries organizations; there is no doubt that from this perspective, the policy is unethical.

The following chapter, Japan's Nuclear Power policy, follows a similar pattern to that of the whaling policy. Vested interest groups influence and direct the policy under the banner of the global environmental cliché of sustainable development. 


\section{CHAPTER FIVE: Case study 2 NUCLEAR ENERGY POLICY \\ The ethics of using nuclear energy}

This chapter looks at the Japanese government's nuclear energy policy with a focus on its ethical component. Whilst scholars and researchers have debated the political, economic, and militaristic aspects of the policy, there have been few inquiries into its moral features, including its potential to harm the environment.

At the end of 2006 Japan was operating 55 light water nuclear power plants that accounted for about one third of its electricity supplies. A further two plants are being built for completion by 2011 and construction has started on an additional eleven. Japan's nuclear power program has now become integral to its economy and its significance in the future as a provider of basic energy will only increase. Monte Bullard stated that "Japan's decision to have a nuclear capability is political, not military". ${ }^{1}$ However, another view is that the decision was neither for political nor for military reasons; it was more to do with commercial reasons. There is a similarity between Japan's nuclear energy policy and other government policies; it is promoted by industry, it is economically focused, and it is technology driven. Japan's nuclear power policy is largely shaped by economics with the consequence that it does not place an adequate value on social considerations or on the environment.

This chapter consists of four parts. The first part explores the development of Japan's nuclear power policy. In comparison to other policies such as those dealing with whaling and forestry, the nuclear power policy is relatively new. It was initiated with a budget allocation of $¥ 250$ million in 1954: the aim and expectation was that it would ensure a secure supply of basic energy. The second part discusses some of the concerns about nuclear incidents such as the 1999 Tokaimura accident, and about Japan's plutonium stockpile. The third part examines the

\footnotetext{
${ }^{1}$ M.Bullard, “Japan's nuclear choice”, Asian Survey, vol. 14, no. 9, September 1974, p. 845.
} 
participants in the nuclear sphere, who they are and how they manipulate and direct the Japanese policy. There are three main players which form a nuclear 'Iron Triangle' and which appear to have a direct as well as an indirect influence; their hidden power is often overlooked in the Japanese nuclear debate. The final part looks at four areas of ethical concern: the policy focus, nuclear waste, nuclear weapons, and the effect on the environment.

\section{The development of Japan's nuclear power policy}

Japan's first encounter with nuclear fission occurred when atomic bombs were dropped on Hiroshima and Nagasaki in August 1945. Less than 20 years after those cataclysmic events, Japan was operating its first nuclear power reactor. Since then, nuclear energy has become a key source of Japan's energy supply serving the needs of Japanese industry as well as serving the needs of energy security. Map 1 shows the number of nuclear power plants built and operating in Japan between 1970 and 2006: it shows a steady increase in the reliance on nuclear power generation. 
Map 1: Nuclear power plants built and operating in Japan between 1970 and 2006

\section{NOTE:}

This map is included on page 163

of the print copy of the thesis held in the University of Adelaide Library.

Source: Genshi nenryō seisaku kenkyūkai (Council for Nuclear Fuel Cycle), Japan ${ }^{2}$

\footnotetext{
${ }^{2}$ Genshi nenryō seisaku kenkyūkai (Council for Nuclear Fuel Cycle), http://www.cnfc.or.jp/j/nuclear/index.html,
} (accessed 31 March 2009). 


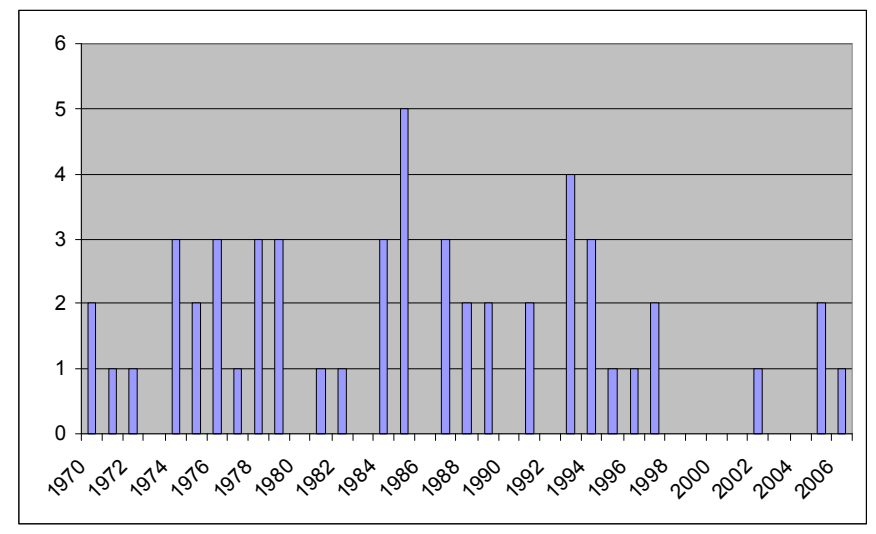

Source: Compiled by the author using information from Nihon no genshiryoku (Japan's nuclear power generators) ${ }^{3}$

To show the sequence of events that influenced Japan's policy development, this section is divided into five parts.

\subsection{Foundation of Japan's Nuclear Power Program (NPP) 1954 - 1960s}

Less than 10 years after World War II ended Japan's NPP was initiated with high hopes that it would contribute to Japan's economic recovery. Because of the country's dependence on external energy resources such as crude oil, coal, and gas, nuclear energy seemed to offer a way to fulfill Japan's ambitions for economic growth. In 1956, the three leading political parties, Nippon Jiyūtō (Japan Liberal Party), Kaishintō (Progressive Party) and Jiyùtō (Liberal Party), submitted a budget of $¥ 250$ million for the development of nuclear power for peaceful purposes. ${ }^{4}$ At a time when Japan was experiencing devastating environmental pollution, this was a huge sum. During a later 3- year period between 1962 and 1965, when environmental pollution such as Minamata disease was a serious public problem, the government allocated a lesser amount of $¥ 220$ million to the Agency of Science and Technology to conduct

\footnotetext{
${ }_{3}^{3}$ Nihon no genshiryoku, http://www.fepc-atomic.jp/thumbnail/infobase/d-04.html, (accessed 7 January 2008).

${ }^{4}$ Nuclear White Paper 1956, by Genshiryoku iinkai, http://www.aec.go.jp/iicst/NC/about/hakusho/wp1956/sb10101.htm, (accessed 18 March 2007).
} 
environment-related research. ${ }^{5}$ This well explains the Japanese government's keenness to introduce nuclear power technology in order to secure the country's energy demands rather than to solve the county's worst pollution occurrences. Taking into account inflation, it indicates that even from the early stages of its policy development, nuclear power has been given great prominence. It is reasonable to suggest that economic growth considerations were the main reasons why such enormous sums were budgeted to this sector.

In 1954 the pelagic tuna fishing boat Daigo Fukuryū maru was exposed to the effects of a hydrogen bomb test conducted by the United States on Bikini Atoll in the Marshall Islands. Twenty three crew members were irradiated and one died as a result. That event, along with the atomic bombing of Japan in 1945, made it difficult for the Japanese government to sell the idea of developing an NPP. However, these events did not deter it as the government was very much focused on rebuilding its economy through new technologies.

Richard Samuels pointed out that modern Japan rallied around the slogan of Fukoko Kkyōhei (Rich Nation, Strong Army) in the 1930s that led to war and devastation. He commented that Japan's postwar architects realized that technological capability was the key to national security; they developed a program that could well be described as "Rich Nation, Strong Technology". 6 The degree of Japan's success was revealed in 1955 when 'Mohaya sengo dewa nai (It is no longer the postwar)' was mentioned in the government's Economic White Paper. The country's remarkable recovery was due to a technologically driven economic development plan: Japan's NPP followed the same path.

In the initial stage the Japanese government took two steps to establish a foundation for the country's NPP. The first was taken in December 1955 when it enacted the Atomic Energy Basic Law (AEBL). The law was the basis of Japan's NPP with regard to the research, development, and use of nuclear power. There were three objectives in the AEBL: one, to secure energy resources, two, to progress science and technology, and three, to promote

\footnotetext{
${ }^{5} 1969$ Kōgai hakusho (Pollution White Paper), Japan, http://www.env.go.jp/policy/hakusyo/hakusyo.php3?kid=144\&serial=11251\&kensaku=1\&word, (accessed 28 March 2008).

${ }^{6} \mathrm{R}$. Samuels, Rich nation, strong army: national security and the technological transformation of Japan, Cornell University Press, Ithaca, 1994, p. 319.
} 
nuclear related industries. The AEBL came into effect in January 1956 and at the beginning of that year the Atomic Energy Commission (AEC) (discussed later) was established; it was the core body for Japan's nuclear power development.

The second step taken was the establishment of the Japan Atomic Energy Research Institute (JAERI) in November 1955; it was a semi-government organization and was the centre for nuclear power research. The government spent $¥ 250$ million to establish the institute ${ }^{7}$; at that stage at least $¥ 500$ million had been spent to start up the NPP. The JAERI set its own regulations based on the $1955 \mathrm{AEBL}$ and thus there were similar aims and objectives. The Japanese government first enacted the law, and then founded the research institute. In May 1956 it established the Science and Technology Agency (STA) under the Prime Minister's Office. The STA is the sole agency in the government to focus on nuclear related science and technology research. By the mid-1950s the collaboration of the JAERI, the AEBL, and the AEC had established the foundation for the NPP. It should be noted that the Japanese NPP not only emphasized its importance for the country's economic prosperity, but also placed emphasis on technological innovation.

The NPP is structured to accommodate both the domestic and international domain. In 1957 Japan joined the United Nation's International Atomic Energy Agency (IAEA); it is an independent intergovernmental organization operating as a branch of the United Nations; it assists governments to develop nuclear technology for peaceful purposes. The Japanese government signed several international treaties in order to demonstrate its intention to use nuclear power in that way. For example, Japan signed the Nuclear Cooperation Treaty with the United States in 1958 and with the UK in $1959 .^{8}$ Japan's first nuclear fission took place in 1958 at the Tokaimura nuclear power facility in Ibaragi prefecture

Because of the emphasis on industrial growth during the 1960s, the Japanese economic structure was heavily dependant on imported raw materials. In 1963 this dependency was 60

\footnotetext{
${ }^{7}$ Nihon genshiryoku kenkyū hō (Japan nuclear power research law), May 1956, revised 2002, http://www.jaea.go.jp/jaeri/jpn/orga/05/pdf/jaeri-law.pdf, (accessed 19 March 2008)

${ }^{8}$ Genshiryoku 2002 (Nuclear energy 2002), The Agency of Natural Resources and Energy of the Ministry of Economy, Trade and Industry, 2002, p. 97.
} 
percent for copper, 33 percent for zinc, and 77 percent for iron; by 1968 these statistics had grown to 74 percent, 54 percent, and 85 percent respectively. ${ }^{9}$ As Japan lacked natural resources, and economic prosperity was the top priority at that time, the use of nuclear power was attractive to both the government and to industry. Japan's high dependency on imported crude oil was an important reason to look for an alternative energy source. The government believed that the answer lay with nuclear energy and it purchased a nuclear power plant from Britain in July 1959; it used enriched uranium fuel that had been processed in the United States. ${ }^{10}$

The power plant was sited at Tokaimura and its facility was upgraded so that by July 1966 it started generating electricity for commercial purposes; it had a generating capacity of 1,660 kw. ${ }^{11}$ Furthermore, as support from the government for the NPP increased, so did the funding. The government nuclear budget in 1969 reached $¥ 30$ billion, up from $¥ 21$ billion in the previous year. ${ }^{12}$

Graph 2: The Japanese nuclear related budget between 1954 and 1969

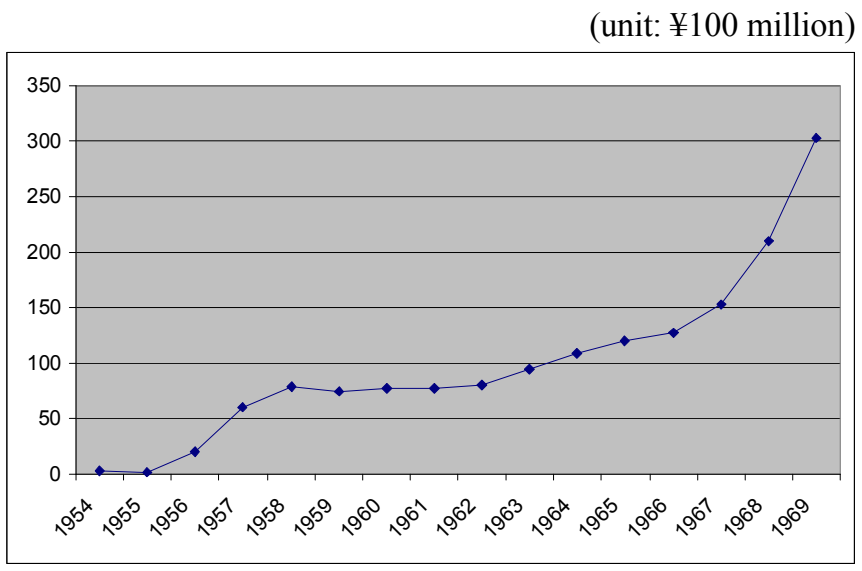

Source: Shōwa 44 nendo Genshiryoku hakusho (1969 Nuclear White Paper), Compiled by the author

\footnotetext{
${ }^{9}$ J. Halliday and G. McCormack, Japan's imperialism today, Penguin Books, Harmondsworth, 1973, pp. 18-19.

${ }^{10} \mathrm{H}$. Tamaru, Dakara genpatsu wa abunai! (That's why nuclear power plants are dangerous), Narusei Shuppan, Tokyo, 1998, p. 70.

${ }^{11}$ Genshiryoku, kyō soshite ashita (Nuclear power, today and tomorrow), The Agency of Natural Resources and Energy of the Ministry of Economy, Trade and Industry, 1998, p. 40.

${ }^{12}$ Nuclear White Paper 1969, by Genshiryoku iinkai, http://www.aec.go.jp/jicst/NC/about/ hakusho/wp1969/sb1401.htm, (accessed 20 March 2008).
} 
As Graph 1 illustrates, the Japanese government steadily increased the amount of its nuclear budget, which jumped from $¥ 250$ million in 1954 to $¥ 30$ billion in 1968 . In 15 years the Japanese government had established a successful NPP.

\subsection{Energy demand (1970s - mid 1980s)}

Due to the great demand for energy during the 1960s, particularly for manufacturing, the Japanese government focused on energy and nuclear power. The two oil shocks of 1973 and 1979 impacted badly on Japan's economy so that the government's agenda at that time placed a strong emphasis on a stable supply of energy resources. The government took three initiatives to implement the development of its NPP.

The first was the establishment of the Agency of Natural Resources and Energy (ANRE) in 1973; it was established under the Ministry of International Trade and Industry (MITI). The ANRE not only promoted the NPP but also planned a strategy to meet the demands of Japanese industry. The ANRE filled the role of architect and developer: as the developer of the program it focused on securing fuel for the country's NPP ${ }^{13}$; a reliable supply of enriched uranium fuel for its power plants was critical. Nuclear power offered resource-poor Japan a new form of energy with the added advantage that it decreased the country's heavy dependency on imported energy resources from politically unstable regions. Japan's crude oil is supplied mainly by Middle Eastern countries, whereas uranium is available from Canada, Australia and Kazakhstan. As the ANRE is under the authority of MITI, its principal focus is on energy security.

The second initiative the government took was to enact three electric power development laws in 1975. They comprise the Special Account Law for Electric Power Promotion, the Electric Power Development Promotion Tax Law, and the Law for the Adjustment of Regions

\footnotetext{
${ }^{13} \mathrm{~T}$. Shibata and H. Tomokiyo, Genpatsu kokumin yoron - Yoron chōsa ni miru genshiryoku ishiki no hensen (A public opinion poll for nuclear power - changes of nuclear awareness through an opinion poll), ERC Shuppan, Tokyo, 1999, p. 47.
} 
Adjacent to Power Generation Facilities. ${ }^{14}$ The ANRE claimed that under the three laws nuclear power plants would have a positive effect on regional areas. ${ }^{15}$ The laws also forced the builders of power plants to have a liability fund of $¥ 60$ billion in case of a accidents; if the claims were higher, then the government would meet them. ${ }^{16}$ Hayden Lesbirel pointed out that the aim of the three laws was to redistribute some of the gains derived from nuclear power generation from city communities into regional communities. ${ }^{17}$ This was a government strategy that aimed at mutual prosperity for both the nuclear power facility operators and the host communities. ${ }^{18}$ Lesbirel suggested that the three laws would give benefits to the areas surrounding the nuclear power sites, and that they aimed at promoting nuclear power development. The impetus for the laws of 1975 could have come from the government's 'Nippon Rettō Kaizō Ron (Japanese archipelago reconstruction plan)' in 1972. Kakuei Tanaka, the Prime Minister at that time, stressed the necessity of public works to revitalize regional economies and said that the three laws attempted to do that.

The third initiative was taken by the AEC when it released a report in the 1980s on safety management and accident prevention at nuclear power facilities. The responsible government bodies, the MITI, and other ministries promised tougher regulations on plant operators. Prior to the introduction of the report, Japan was operating 18 nuclear power plants and by the end of the 1970s numerous incidents such as the leakage of primary cooling water had occurred. ${ }^{19}$ The actions of domestic environmental movements may have been a contributing factor, but public doubt and dissatisfaction with the government's nuclear program grew. During the 1960 s and 1970s in which there were four major pollution cases, there became a greater public awareness of domestic environmental problems. The first lawsuit to prevent the construction of a power plant was lodged in 1973: since then there have been similar lawsuits, particularly in the Western parts of Japan. ${ }^{20}$ In 1974 the Japanese nuclear power submarine Mutsu had a

\footnotetext{
${ }^{14}$ Genshiryoku 2002 (Nuclear Energy 2002), p. 93.

${ }^{15}$ Ibid., p. 93.

${ }^{16}$ Ibid., p. 95 .

${ }^{17}$ H. Lesbirel, NIMBY politics in Japan, energy sitting and the management of environmental conflict, Cornell University Press, Ithaca, 1998, p. 36.

${ }^{18}$ Genshiryoku 2002 (Nuclear Energy 2002), p. 93.

${ }^{19}$ Nuclear White Paper 1972, by Genshiryoku iinkai, http://www.aec.go.jp/jicst/NC/about/hakusho/wp1972/sb2010201.htm, (accessed 27 March 2008).

${ }^{20}$ Shibata and Tomokiyo, Genpatsu kokumin yoron - Yoron chōsa ni miru genshiryoku ishiki no hensen (A public opinion poll for nuclear power - changes of nuclear awareness through an opinion poll), pp. 35-37.
} 
radiation leakage and the AEC realized that it had to take seriously safety issues relating to nuclear power operations. There were 36 incidents and equipment breakages at plants reported in $1978,{ }^{21}$ but the government had confidence in its safety regulations as no humans had been affected. The issuing of the safety report was meant to give an assurance that the government was prepared to tackle safety issues: this did not however slow down the building of further nuclear reactors.

The two major nuclear power plant accidents at Three Mile Island in the United States in 1979, and at Chernoble in the former Soviet Union in 1986, shocked the world. The scope of the environmental pollution and the loss of life at Chernoble led to a questioning in Japan of whether the potential threats to communities near nuclear facilities were being taken seriously enough. In spite of the accidents, the promoters behind Japan's NPP continued the construction and operation of further power plants. By 1988 Japan was the world's fourth largest producer of nuclear powered electricity generation with a capacity of $28,046 \mathrm{MW}$, following the US, France, and the Soviet Union. ${ }^{22}$

1.3. The global environment and nuclear energy (1990-)

As a result of the serious environmental damage caused by the Chernobyl accident in the late 1980s, the Japanese public started to express concerns about their own environment. The government however believed that nuclear power development was an economic necessity as well as providing an alternative primary source of electricity production to crude oil, a fuel that emits carbon dioxide and other environmentally hazardous materials.

Japan strengthened its nuclear power policy by participating in international meetings such as the G7 Summit in Paris in July 1989. Because of the tremendous concerns regarding global environmental issues, some countries, particularly the world's richest countries, believed that

\footnotetext{
${ }^{21}$ Nuclear White Paper 1982, by Genshiryoku iinkai, http://www.aec.go.jp/jicst/NC/about/hakusho/wp1982/sb1010104.htm, (accessed 27 March 2008).

${ }^{22} \mathrm{R}$. Drifte, Japan's rise to international responsibilities, the case of arms control, Atlantic Highlands Press, London, 1990.p. 30.
} 
using nuclear power provided the solution. Since then the Japanese government has actively engaged in global environmental diplomacy by advocating nuclear power. In the 1990s, the government continued to argue that harnessing nuclear power energy was the most promising method both for its economy and for the environment. In June 1990 an advisory committee from the MITI dealing with composite energy research reported on forecasts for future energy supplies and demand. In that report the government announced that Japan would build approximately 40 more nuclear power plants over the next 20 years. ${ }^{23}$ The government continued to emphasize the 'environmentally friendly' aspect of the use of nuclear power generators. In the 1990s alone, 15 new reactors were built, comprising both Boiling Water Reactors and Pressure Water Reactors.

In 1987 the World Commission on Environment and Development presented a paper titled, 'Our Common Future', also known as the Bruntland Report. It greatly influenced the Japanese government to become actively involved in global environmental concerns. In its Environmental White Paper of 1988, the government promoted itself with the slogan 'Sekai ni kōken suru kokka (The country that contributes to the world)'. In 1989, two international organizations, the International Energy Agency and the Organization for Economic Cooperation and Development, stressed the importance of nuclear power generation from a global warming perspective. The G7 (USA, Germany, France, UK, Italy, Canada and Japan) meeting at the Arch Summit in Paris acknowledged the benefits of developing nuclear power, and because of the Chernoble accident, also acknowledged the safety issues involved. The leaders at the meeting recognized that using nuclear power had an important role to play in reducing the output of greenhouse gases into the atmosphere. ${ }^{24}$ However, Vince Taylor maintained that the so called 'clean' nuclear reactor method would have only a modest effect on decreasing the rate of world carbon dioxide emissions, a rate that could result in climatic disaster. $^{25}$

\footnotetext{
${ }^{23}$ Shibata and Tomokiyo, Genpatsu kokumin yoron - Yoron chōsa ni miru genshiryoku ishiki no hensen (A public opinion poll for nuclear power - changes of nuclear awareness through an opinion poll), p. 106.

${ }^{24}$ The Paris Summit on international concerns about the environment, Population and Development Review, vol.15, no. 3, September 1989, p. 586.

${ }^{25}$ V. Taylor, "Living without nuclear energy", in M. Kaku and J. Trainer (eds.), Nuclear power, both sides: the best arguments for and against the most controversial technology, Norton, New York, 1982, p. 158.
} 
The Japanese government used this point, among others, to justify its use of nuclear power. However, Japan's nuclear power diplomacy focused very much on the economic advantages; less significance was attached to the advantages to the environment.

Japan hosted two international conferences, the 1993 G7 Summit in Tokyo, and the 1997 Third Conference of the Parties (COP-3) in Kyoto. These two conferences strengthened the government's determination to further develop its nuclear power policy. With global warming a major concern, being the host to the two conferences gave the government a trump card to show its commitment to the betterment of the global environment. Japan has built up its domestic nuclear power industry and strengthened its cooperation with the other nuclear power countries. Japan's White Paper on nuclear power in 1994 mentioned for the first time international cooperation and since then the government has been active in this sphere. The cooperation has varied from technical cooperation to sharing scientific and physics studies relating to nature with the USA, France, Canada, China, Indonesia, and many other countries. $^{26}$

During the 1990s when the government was focused singularly on nuclear technology, there were numerous nuclear related incidents and accidents (refer to Table 1), from the leakage of contaminated cooling water at Takahama to the accident at the Tokaimura reprocessing facility. The latter accident caused two employees to die from radioactivity and exposed many others to radiation contamination (discussed later).

\subsection{Sustainable supply and environmental preservation (2001-)}

At the beginning of 2001 Japan was operating 51 nuclear power plants and was the world's third largest producer of nuclear power, following the United States and France. In spite of the Tokaimura accident, at the beginning of the $21^{\text {st }}$ century the Japanese government gave a number of reasons as further justification for its promotion of nuclear power. These reasons included the sustainability of electricity supplies, environmental preservation, and the low cost

\footnotetext{
${ }^{26}$ Nuclear White Paper 1994, by Genshiryoku iinkai, http://www.aec.go.jp/jicst/NC/about/hakusho/wp1994/sb1020901.htm, (accessed 28 March 2008).
} 
of electricity to consumers. The ANRE announced in 2001 that it would be necessary to build 13 more nuclear power plants (each of $1693.7 \mathrm{kw}$ capacity) by $2010 .^{27}$

From 2000 Japan has consistently emphasized that technological innovation contributes to its NPP. This emphasis on technological innovation is regularly found in other government policies, such as those related to environmental issues. The ANRE stated in 2007 that the Fast Breeder Reactor (FBR) project had the largest budget allocation in nuclear related activities, with the allocation for the joint venture between the METI and the Ministry of Education, Science, Sports and Technology (MEXT) at $\$ 130$ million. ${ }^{28}$ The advantage of FBRs is that they produce plutonium during their operation (discussed later); thus for energy starved Japan, this technological development is extremely attractive.

Another area into which Japan has put a lot of effort is 'uranium diplomacy', the aim being to secure sustainable supplies of that material. In August 2006 Prime Minister Junichiro Koizumi visited Kazakhstan in order to secure a bilateral agreement on nuclear energy. The agreement included "joint development of uranium mines, uranium conversion, fuel processing, and introducing nuclear power generation". ${ }^{29}$ Furthermore, the government provided risk money to back private companies searching for uranium and thus acquire rights to any finds: the budget for this in the financial year 2007 was about $\$ 1.3$ million. ${ }^{30}$ The procurement of uranium has been a central endeavor in Japan's NPP.

\section{Concerns: Japan's nuclear power facilities}

Japan's determination to use nuclear power for electricity generation raises questions of safety. It is a fact that Japan's nuclear power plants have contributed a new source of supply to the

\footnotetext{
${ }^{27}$ Sōgō shigen enerugī chōsakai kara no messēji (message from the General Natural Resource Energy Investigation Committee), by the Agency of Natural Resources and Energy, 2001, p. 21.

${ }^{28} 2007$ nen do 'Genshiryoku rikkoku keikaiku' Kanren yosan no gaiyō (Outline of the related budget of 'nuclear state plan' in 2007), the Agency of Natural Resources and Energy, 2006, http://www.enecho.meti.go.jp/policy/nuclear/pptfiles/070111a.pdf, (accessed 11 January 2008).

${ }^{29}$ Nuclear energy nation plan - main points and policy package September 2006, the Agency of Natural Resources and Energy, p. 2, http://www.enecho.meti.go.jp/english/report/rikkokugaiyou.pdf, (accessed 9 January 2008).

${ }^{30}$ Ibid., p. 2.
} 
electricity grid that serves both industry and households; however there have been concerns over the numerous mishaps that have occurred in nuclear facilities within Japan.

\subsection{Mishaps at nuclear facilities}

In March 2000 the work ethic of some of those involved in the nuclear industry was the focus of the world's media. It was reported that at the nuclear processing plant in Sellafield England, its production staff out of sheer laziness had deliberately falsified the safety standards of their processed pellets, and a complacent management in the plant had allowed the problem to continue for years. ${ }^{31}$ This had important implications for the Japanese nuclear industry as it had been supplied with those pellets. The consequences of unethical work practices, and an irresponsible administration within organizations that handle dangerous nuclear substances, are often not confined to the one facility.

In 2002, a technician working for Tokyo Electric Power Company revealed dishonest practices within the company: it had concealed and falsified inspection data and had for years concealed multiple damaging incidents at its nuclear power plants. A moral consciousness put an end to this unethical procedure and exposed its malpractices and the inadequate supervision by government bureaucrats.

In spite of the government's determination to convince its citizens of the benefits of nuclear power generation, as the result of numerous nuclear mishaps they have continued to be apprehensive. Table 2 lists reported nuclear mishaps in Japan. This sense of uneasiness has been particularly noticeable among people living in communities that are located near nuclear facilities. Robert Goodin noted that "risk aversion increases with the size of the stakes and people are less willing to accept risks associated with new, large-scale, and untested technologies". 32

\footnotetext{
${ }^{31}$ The Weekend Australian, 11-12 March 2000.

${ }^{32}$ R. Goodin, "No moral nukes", Ethics, Vol. 90, No. 3, April 1980, p. 422.
} 
Table 1: Reported nuclear related mishaps in Japan

\begin{tabular}{|c|c|c|c|}
\hline Date & Place & Origins of the mishap & $\begin{array}{c}\text { Amount of } \\
\text { damage }\end{array}$ \\
\hline $\begin{array}{l}\text { 3/Nov. } \\
1979\end{array}$ & $\begin{array}{l}\text { Takahama nuclear power } \\
\text { plant (no.2) }\end{array}$ & $\begin{array}{l}\text { The leakage of primary } \\
\text { cooling water }\end{array}$ & Not major \\
\hline $\begin{array}{l}\text { 6/Jan. } \\
1989\end{array}$ & $\begin{array}{l}\text { Fukushima } 2^{\text {nd }} \text { nuclear } \\
\text { power plant }\end{array}$ & $\begin{array}{l}\text { The breakage of a } \\
\text { primary cooling water } \\
\text { pump }\end{array}$ & Not major \\
\hline $\begin{array}{c}\text { 9/Feb. } \\
1991\end{array}$ & $\begin{array}{l}\text { Mihama nuclear power } \\
\text { plant (no.2) }\end{array}$ & $\begin{array}{l}\text { The leakage of primary } \\
\text { cooling water }\end{array}$ & Not major \\
\hline $\begin{array}{c}\text { 8/Dec. } \\
1995\end{array}$ & Monju-FBR & $\begin{array}{l}\text { The leakage of sodium } \\
\text { solution }\end{array}$ & $\begin{array}{l}\text { Fire and then } \\
\text { sodium chemical } \\
\text { compound was } \\
\text { released }\end{array}$ \\
\hline $\begin{array}{l}\text { 11/Mar. } \\
1997\end{array}$ & $\begin{array}{l}\text { Tokaimura low level } \\
\text { radiation waste water } \\
\text { processing facility }\end{array}$ & $\begin{array}{l}\text { A fire causing an } \\
\text { explosion and the } \\
\text { emission of combustible } \\
\text { gases }\end{array}$ & $\begin{array}{l}37 \text { workers were } \\
\text { irradiated }\end{array}$ \\
\hline $\begin{array}{l}\text { 14/Apr. } \\
1997\end{array}$ & Fugen-new converter & $\begin{array}{l}\text { The leakage of } \\
\text { radioactive sodium }\end{array}$ & $\begin{array}{l}11 \text { workers were } \\
\text { irradiated }\end{array}$ \\
\hline $\begin{array}{c}16 / \text { Oct. } \\
1997\end{array}$ & Fugen-new converter & $\begin{array}{l}\text { The leakage of } 2 \text { tons of } \\
\text { primary cooling water }\end{array}$ & Not major \\
\hline $\begin{array}{c}\text { 5/Nov. } \\
1997\end{array}$ & Fugen-new converter & $\begin{array}{l}\text { The leakage of heavy } \\
\text { water from a purification } \\
\text { refinery }\end{array}$ & $\begin{array}{l}2 \text { workers were } \\
\text { irradiated }\end{array}$ \\
\hline $\begin{array}{c}\text { 12/July. } \\
1999\end{array}$ & $\begin{array}{l}\text { Tsuruga nuclear power } \\
\text { plant (no.2) }\end{array}$ & $\begin{array}{l}\text { The leakage of primary } \\
\text { cooling water }\end{array}$ & Not major \\
\hline $\begin{array}{l}\text { 30/Sep. } \\
1999\end{array}$ & $\begin{array}{l}\text { Tokaimura, JCO uranium } \\
\text { reprocessing facility }\end{array}$ & Rinkai (critical point) & $\begin{array}{l}2 \text { workers died and } \\
439 \text { people were } \\
\text { irradiated }\end{array}$ \\
\hline $\begin{array}{l}\text { 7/Nov. } \\
2001\end{array}$ & $\begin{array}{l}\text { Hamaoka nuclear power } \\
\text { plant (no.1) }\end{array}$ & $\begin{array}{l}\text { Break down in the system } \\
\text { of surplus heat removal } \\
\text { and steam condensation } \\
\text { pipes }\end{array}$ & Not major \\
\hline
\end{tabular}

Sources: Compiled by the author using several resources such as Genshiryoku 2002 and Genpatsu no honto to uso.

It should be noted when looking at Table 1 that an accident is deemed to have occurred when the mishap is rated 4 or higher on the STA's International Atomic Energy Agency (IAEA) scale (ranging upwards from 1 to 7), whilst when less it is deemed an incident.

Table 1 illustrates that the leakage of primary cooling water was the most common mishap. The first two, at Takahama and Fukushima, occurred in reactors that were only 4 years old and 
gives cause for concerns about the future. What is apparent is that many of the mishaps both major and minor were the result of human error.

A graphic example for justifiable public concern was the 1999 Tokaimura accident. It showed how human error created the potential for a catastrophic accident, and how the Japanese government had been negligent in enforcing safety standards. A detailed examination of this accident reveals how the company involved and the government regulators failed in their safety management practices. That the government allowed the company to operate under such conditions, with its inherent dangers, is ethically indefensible.

\subsection{The Tokaimura nuclear facility accident.}

This accident occurred on $30^{\text {th }}$ September 1999 and rated 4 on the IAEA scale. The accident caused the death of two employees and challenged the standards of safety management within the government and within the nuclear industry. The plant processes uranium oxide for commercial reactors and is located about $125 \mathrm{~km}$ Northeast of Tokyo. The facility is owned by a private nuclear fuel processing company named JCO Co. and was established in 1980: it was previously named the Japan Nuclear Fuel Conversion Co. and it is a fully owned subsidiary of Sumitomo Metal Mining Co. The Tokaimura accident was Japan's worst nuclear facility accident and it revealed lax work practices, and lax supervision by the regulatory authorities. This section focuses on two aspects of it; firstly to ascertain the nature of the accident, and secondly to examine Tokaimura's dilemma in relation to the three laws of 1975.

\subsubsection{The nature of the accident}

There were two primary causes for the accident. The first was the lack of training of the plant workers who were directly involved. It was reported that when they were mixing a uranium compound with nitric acid solution to produce fuel for a reactor power plant, they only realized that an accident had occurred when blue flames were spotted in the sedimentation 
tank. ${ }^{33}$ The blue flames phenomenon is known in Japanese as Rinkai; it is the point at which neutrons produced in the fission process are sufficient to sustain a chain reaction. ${ }^{34}$

The workers involved in the processing operation made two mistakes that led to the fatal accident. The first mistake was their laxity in heating up a stainless steel bucket in which to dissolve highly enriched uranium; to use such a method in a potentially dangerous environment is unbelievable. According to a media report, one of the workers said that the bucket's capacity of about 18 litres was quite useful because they could accurately measure the concentration. ${ }^{35}$ They made their second mistake when they carelessly poured $16 \mathrm{~kg}$ of the enriched uranium, instead of the normal amount of $2.3 \mathrm{~kg}$, into the sedimentation tank. Rinkai was then reached. Due to their lack of knowledge, the workers were unaware of the possible consequences of their actions. In spite of working at the plant for many years, one of the workers had only a few months experience in making the nitric acid/uranium solution for the Joyo fast breeder reactor, ${ }^{36}$ whilst the other two had only performed the operation for ten days. $^{37}$

The second contributing factor to the accident was the negligence of JCO. The company had ignored a directive in the government manual and allowed their workers to use a stainless steel bucket in which to dissolve the uranium; this unauthorized method had been in use since November 1996. The operation at the Tokaimura nuclear facility was to take impurities out of uranium oxide powder. The procedure was to first dissolve the uranium oxide powder in a dissolution tank, and then to put it into a storage tank to homogenize and then become a uranium solution. ${ }^{38}$ The three workers heated up the stainless steel bucket using a portable electric heater in order to facilitate dissolving the uranium powder and nitric acid. ${ }^{39}$ The workers believed that if they wore gloves and a mask then the substances would not be

\footnotetext{
${ }^{33}$ Asahi Shimbun, 1 October 1999.

${ }^{34}$ Ibid., 30 September 1999.

${ }^{35}$ Ibid., 7 October 1999.

${ }^{36}$ Ibid., 4 February 2000.

${ }^{37}$ Ibid., 3 October 1999.

${ }^{38}$ A newsletter about the 'Rinkai accident at JCO power plant', by the Agency of Science and Technology, the Government of Japan, 15 October 1999.

${ }^{39}$ Asahi Shimbun, 4 November 1999.
} 
dangerous, and that the heating method they used would make it quicker and easier for them to perform the operation. ${ }^{40}$

The Level 4 accident at Tokaimura was the worst recorded at a Japanese nuclear facility. Three months later in February 2000 around 450 people living around the nuclear facility were diagnosed as suffering from the effects of radiation exposure. The accident was caused by human error and by those in authority failing to act in accordance with required safety standards. Japanese corporate practices (discussed in the next chapter) that ignore the foundation of Rinri for the sake of profits clearly do not follow what has been taught by thinkers and scholars in Japanese history to ensure healthy relationships within the society.

\subsubsection{Tokaimura's dilemma}

The location of Japan's nuclear power plants pose dilemmas for those people living nearby. In 1955 two villages merged and this became the site of the Tokaimura facility where Japan's first nuclear power plant was established. The reactor has operated continuously since its construction in 1996. Known as the capital of Japan's nuclear power industry, Tokaimura's power facility has supplied the surrounding areas with relatively cheap electricity as well as providing the local people with many job opportunities on high wages. ${ }^{41}$ The initiatives for the establishment of the Taikamura facility are found in the government's Three Laws of 1975 (discussed earlier). The ANRE assured the community that by accepting the nuclear power facility it would have a positive effect on the regions prosperity, and that the Three Laws would apply to Tokaimura. The town had received about $¥ 61$ billion of fixed assets by 1998 and of those assets, $¥ 48.1$ billion related to the nuclear power facilities. About one third of the town's workforce was employed at the facility. ${ }^{42}$ Tokaimura has become a 'nuclear' town as its economic wellbeing is heavily dependent on the nuclear operations; the fact that the town with a population of 34,000 has 140 restaurants gives an indication of its prosperity. However, soon after the 1999 accident it was clear that the town's primary industries, particularly

\footnotetext{
${ }^{40}$ Asahi Shimbun, 7 October 1999.

${ }^{41}$ The Weekend Australian, 9-10 October 1999.

${ }^{42}$ Asahi Shimbun, 23 December 1999.
} 
agriculture and fisheries, were critically damaged as a consequence of that accident. Sales of produce from the area and other parts of Ibaraki prefecture were affected on the basis of hearsay. Although not contaminated by the accident, fruit and vegetables from the area were rejected at wholesale markets. Trading in fish from the area was suspended by the Fisherman’s Cooperative Association, causing a loss to the local fishermen of $¥ 5-6$ million a day. ${ }^{43}$ It was reported that by the end of 1999 the losses to primary industries amounted to about $¥ 1$ billion. ${ }^{44}$ The Three Laws may bring economic benefits to some communities, but without an adequate safety management scheme the main beneficiary remains the nation's nuclear power industry. These electric utilities are private companies geared towards profit; their shareholders are shielded by distance so that safety management at the plants is indeed an ethical issue.

\section{The power behind Japan's nuclear power development}

Japan's nuclear power policy has been shaped and developed by three main interest groups, two government bureaucracies and the Japanese nuclear industry. At the centre of the nuclear triangle is the Atomic Energy Commission (AEC) (refer to Figure 1). The two bureaucracies are the MEXT and the METI. Whilst the MEXT has the role of researcher and concentrates on nuclear research and development, the METI is the regulator and manages the safety issues of nuclear power. The third member is Japan's nuclear power industry. This group is the key player in determining government policy direction and is largely an unseen force behind policy formulation; it influences and directs the Japanese NPP. Scholars such as Hayden Lesbirel, speaking on NIMBY politics in Japan, have looked at the development of the nuclear energy facilities. However, limited attention has been given to Japan's 'nuclear power vested interest groups' who influence and manipulate the direction of government policy.

\footnotetext{
${ }^{43}$ Asahi Shimbun, 2 October 1999.

${ }^{44}$ Ibid.
} 


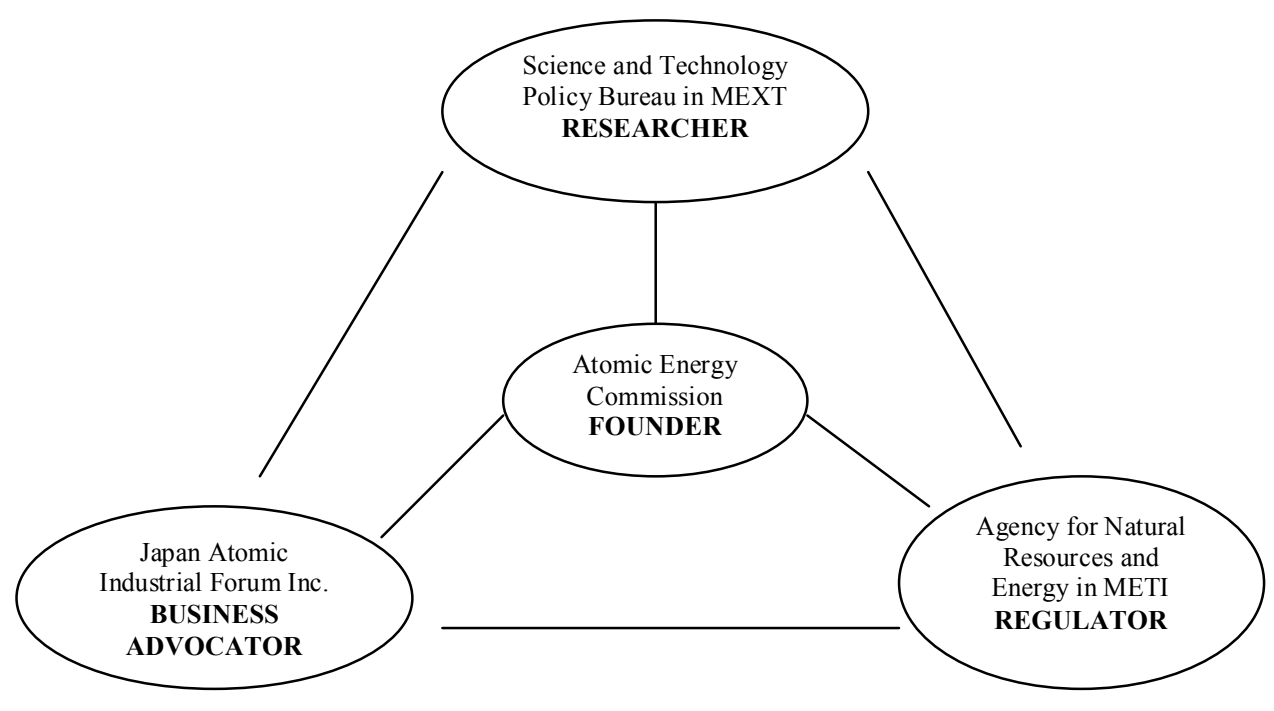

Source: Compiled by the author

3.1. Genshiryoku I'inkai: 原子力委員会 - The Atomic Energy Commission of Japan

The Japanese AEC was established in 1956 and its role varies from conducting research to regulating nuclear power generation; it is a long-serving body dedicated to the development of Japan's NPP. The AEC is pivotal to policy formulation; the background to its establishment was the enactment of the AEBL in 1955 (discussed earlier). One of the AEC's responsibilities is to put nuclear research into nuclear practice for safe and peaceful purposes.

There are two features of the AEC that confirm its significant position in policy development. The first is that it is set up within the Cabinet Office of the Japanese Government. The authority of the AEC is such that it formulates the framework of Japan's Nuclear Energy policy, and checks the administrative judgment of other associated government 
organizations. ${ }^{45}$ The AEC has five commissioners appointed by the Prime Minister to coordinate its operations. Although the AEC is the central administrative link to other relevant ministries such as the MEXT and the METI, it does not have controlling power over the policy direction. Even though the AEC is at the centre of policy making, it remains a neutral facilitator within the triangle. The AEC has operated within the Cabinet Office for more than 50 years and this point illustrates its central position in the central government's considerations; it is the foundation on which the policy is built.

The second feature of the AEC is that it has the power to determine budget allocations for the implementation of the government policy. The AEC not only submits fiscal estimates but also distributes finance to other relevant ministries. The nuclear-related budget for 2007 was in total around $¥ 483$ billion, an increase of $¥ 40$ billion from the previous year. ${ }^{46}$ There are five ministries (the MEXT, the Cabinet Office, the Ministry of Foreign Affairs, the Ministry of Internal Affairs and Communications, and the Ministry of Land, Infrastructure, Transport, and Tourism (MLIT) involved, to which the AEC distributes funds. Requests vary from $¥ 36$ million for the MLIT to $¥ 134$ billion for the MEXT. ${ }^{47}$ There are other ministries involved in Japan's nuclear energy program and the Ministry of the Environment (MOEN) is one of them. However, its involvement is only to give an environmental assessment of nuclear power facilities; it has no budget allocation. This clearly shows that environmental values do not rate highly in Japan's nuclear power deliberations. The AEC cooperates with other ministries and agencies to lead the nation's nuclear power development, and has maintained its central role of administrator in policy formulation.

\footnotetext{
${ }^{45}$ Administrative organizations for nuclear energy policy, the Atomic Energy Commission, http://www.aec.go.jp/jicst/NC/about/organizations.pdf, (accessed 23 January 2008).

${ }^{46}$ Heisei 19 nendo Genshiryoku kankè keihi gaisan yōkyū gaku (requested budget for nuclear related estimates for 2007), by the Atomic Energy Commission, 5 September 2006, http://www.aec.go.jp/jicst/NC/iinkai/teirei/siryo2006/siryo35/siryo2.pdf, (accessed 21 January 2008).

${ }^{47}$ Ibid.
} 
3.2. Science and Technology Policy Bureau under the MEXT

The Science and Technology Policy Bureau (STPB) focuses on the research and development of the nuclear energy program. Operating under the MEXT, the STPB is an entity resulting from a merger in 2001 of the Ministry of Education, and of the Science and Technology Agency (STA). The STA and the AEC were both established in 1956. It is little known that the STA operates under the same umbrella of Prime Minister's Cabinet Office as the NPP and focuses on nuclear energy research. As a consequence of the merger, the STPB is involved with two areas, nuclear research and energy research.

The STPB believes that the use of nuclear power is an extremely important element in Japan's quest to ensure a secure and adequate supply of primary energy resources. The STPB considers that nuclear power is not only a provider of energy but also the source of Japan's industrial strength. In the 2007 White Paper, the MEXT emphasized the high value of science and technology; the paper further stated that they play an important part in the Japanese strategy for industrial survival. The MEXT defines an important strategy as not only involving national security but also industrial security. The MEXT believes that nuclear power technology strengthens the global competitiveness of Japanese industries. ${ }^{48}$

The strength of the STPB is that as it has been the core research body for science and technology, it attracts large allocations from the government budgets. The MEXT requested a total budget of $¥ 1.2$ trillion for 2007 ; from that budget the largest allocation ( $¥ 285$ billion) went to the nuclear power sector, followed by $¥ 228$ billion for Japan’s space aeronautics. ${ }^{49}$ The MEXT also allocated $¥ 31$ billion to the Fast Breeder Reactor (FBR) project (discussed later). ${ }^{50}$ Thus from the 2007 budget, it gave a total of $¥ 316$ billion to the nuclear power sector.

The role of the STPB is to collaborate with the AEC and other related bodies; its position is therefore extremely important in determining Japan's nuclear policy direction. Not only does

\footnotetext{
${ }^{48}$ Heisei 19nen do gaisan yōkyū shuyō jikō (requested budget for main items for 2007), by the Ministry of Education, Culture, Sports, Science and Technology, available at: http://www.mext.go.jp/b menu/houdou/18/08/06083104/012.htm, (accessed 25 January 2008).

${ }^{49}$ Heisei 19nen do gaisan yōky ū shuyō jikō (requested budget for main items for 2007).

${ }^{50}$ Ibid.
} 
it have access to large sums of money through the MEXT for Research and Development, but the STPB also influences Japan's future national policies. The major emphasis in these policies is 'technology'. Nuclear power technology is not only about energy security, it is also about assisting the Japanese nuclear industry to grow. The cozy relationship between government-funded technology and industry (business) can be seen in other government policies, in particular in environmental policies. The Japanese government's emphasis on technology for development and problem solving has remained constant over the last half century.

\subsection{Agency for Natural Resources and Energy under the METI}

The ANRE was established in 1973 when the first oil shock hit Japan. The crisis of energy resources, particularly imported crude oil, on which Japan had become so dependent, prompted the ANRE's establishment. It is one of the key bodies that determines the nuclear energy policy and is responsible for policies concerning the supply of primary energy resources that include crude oil, coal, natural gas, and uranium. The ANRE, along with the AEC and the STPB, emphasizes the importance of nuclear energy, but a significant difference between them is that the ANRE has a close liaison with the nuclear industry. Its primary role is to secure Japan's energy resources; it also collaborates with the industry to promote the use of nuclear energy. Apart from its core role, the ANRE has since 2001 emphasized environmental protection and efficiency. ${ }^{51}$

The importance of the ANRE can be seen from the METI's budget distribution. In the 2008 budget the METI was to receive about $¥ 1$ trillion, of which around $¥ 722$ billion was then allocated to the natural resource and energy policy, the highest allocation by the METI. ${ }^{52}$ By contrast, the lowest at $¥ 65$ billion was allocated to the revitalization of rural regions and small

\footnotetext{
${ }^{51}$ Sōgō shigen enerugī chōsakai kara no messēji (Message from the research committee on natural resource energy) by The Agency for natural resource and energy, 2001, pp. 5-6.

${ }^{52}$ Heisei 20nen do keizai sangyōshō yosanan no gaiyo (Outline of the budget of the Ministry of Economy, Trade and Industry in 2008), The Ministry of Economy, Trade and Industry, 2007, http://www.meti.go.jp/press/20071224001/01 yosan.pdf, (accessed 3 April 2008).
} 
to medium sized Japanese companies. ${ }^{53}$ The budgetary allocations indicate the ability of government agencies to initiate and implement policies, not least in the ability of the ANRE to promote Japan's nuclear energy interests. In fact, the ANRE plays a commanding role in Japan's nuclear policy formulation and an assisting role in Japan's nuclear industry.

As a result of the restructuring of the Japanese central government in 2001, many ministries and agencies were reformed and restructured. As the safety aspect of nuclear power generation had become an important issue, in January 2001 under the METI the Nuclear and Industrial Safety Agency (NISA) was established. The NISA has focused on the safety aspect of nuclear power generation which previously had been covered by the ANRE and the STA. According to the ANRE its mission was to assure safety in nuclear power facilities and to stress government responsibility to enforce safety strategies. ${ }^{54}$ Thus the role of the NISA is important as it is the bridge between the Japanese government and the nuclear industry. The NISA is also the authority responsible for Japan's nuclear power regulation.

That the ANRE collaborates closely with Japan's nuclear industry is shown through a number of actions. The ANRE has placed stringent regulations on companies involved in the nuclear industry, such as those establishing, operating and managing power plants. It assesses applications and decides on whether to grant permission for such operations. ${ }^{55}$ The ANRE, and the NISA in particular, play a regulatory role between government bodies and the nuclear industry.

\subsection{Japan Atomic Industrial Forum Inc.}

Concerns over Japan's nuclear capabilities have been widely debated among scholars and researchers, but the nuclear power industry itself has in the past received modest attention. The role of Japan Atomic Industrial Forum Inc. (JAIF) has been extremely important for the

\footnotetext{
${ }^{53}$ Heisei 20nen do keizai sangyōshō yosanan no gaiyō (Outline of the budget of the Ministry of Economy, Trade and Industry in 2008).

${ }_{55}^{54}$ The Ministry of Economy, Trade and Industry, Japan, Nuclear and Industry Safety Agency, 2002, p. 2.

55 Ibid., p. 6.
} 
development of the Japanese nuclear power policy. The JAIF was established in 1956 and it is the voice of the Japanese nuclear industry; it has become an industry and could be described as 'Japan Nuclear Inc.'. Japan's big business takes a keen interest in government policy making where its interests are affected and this applies to Japan's nuclear policy; the JAIF has been central in influencing the direction of this policy. The Nuclear Inc. network is shown in Figure 2; it illustrates the close connection between the nuclear industry and the Japanese government.

Figure 2: The Nuclear Inc. network

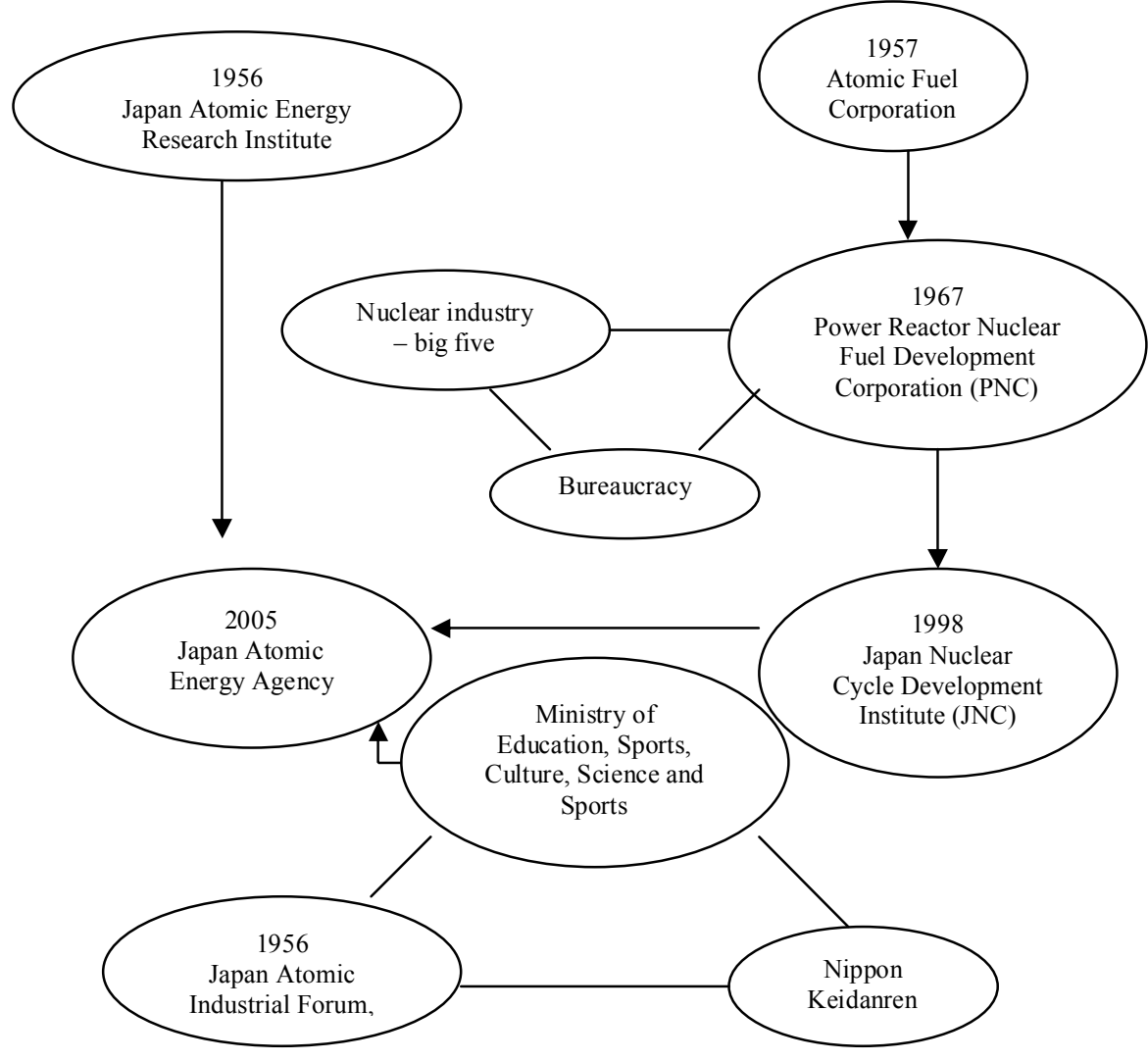

Source: Compiled by the author

The JAIF has strengthened itself and has become a more influential voice in government policy making. It promotes nuclear policy development to the government as well as 
supporting Japan's economic development through the pursuit of peaceful utilization of nuclear energy and its technology. ${ }^{56}$ There are four features of the JAIF that demonstrate its ability to influence Japanese government policy decisions and direction.

The first is that the JAIF has a close connection with the Japanese government and with Nippon Keidanren (Japan Business Federation), hereafter referred to as Keidanren. It is Japan's biggest economic organization and provides the thrust for the nation's economic prosperity. This close connection is a decisive element for the JAIF as the Keidanren exerts a strong influence over government policy-making (discussed in Chapter 3). The intimacy of the relationship is shown through the appointment of JAIF executives who have previously held top positions within the Keidanren. The JAIF chairman Takashi Imai was previously an honorary chairman of the Keidanren, the JAIF president Takuya Hattori was the chairman of the Environment and Safety committee of the Keidanren, and the vice president of JAIF, Yumi Akimoto, was the chairman of the Energy and Resources committee of the Keidanren. The latter two positions were held around 2005. The blending together of the two bodies provide a powerful, persuasive influence on government policy making.

The second significant feature is the size of the organization. The JAIF has more than 450 corporate members and 21 executives. It is composed of electric power companies, nuclear vendors, nuclear research organizations, Sōgō Shōsha (general trading companies), and local governments that own nuclear power plants. ${ }^{57}$ Large, influential Japanese companies such as Mitsubishi and Toshiba are actively involved in developing nuclear business and are members of the JAIF. It is reasonable to suggest that the JAIF operates under the Keidanren umbrella.

The third feature is the astronomical sums of money that are being poured into the Japanese nuclear power business. The October 2007 report of the JAIF showed that it is an industry worth $¥ 3$ trillion (approximately US\$30 billion). The 2006 nuclear related industry indicator showed that $¥ 1.7$ trillion was spent on electricity generation ventures and $¥ 1.6$ trillion in

\footnotetext{
${ }^{56}$ Introduction to JAIF, by Japan Atomic Industrial Forum, Inc., November 2007 http://www.jaif.or.jp/english/news/2007/jaif brochure2007.pdf, (accessed 29 January 2008).

${ }^{57}$ Introduction to JAIF, by Japan Atomic Industrial Forum, Inc.
} 
purchases of steel by the industry. ${ }^{58}$ Even though there have been fluctuations in development and sales over the last 20 years, the total amount expended on the industry has remained fairly constant. Hiroaki Koide and Akira Adachi reported that the industry had spent $¥ 3$ trillion annually on nuclear research and technology. ${ }^{59}$ Some idea of the size of the industry can be gauged by the human resources involved; in 2006 there were 45,885 people employed in the private nuclear sector. ${ }^{60}$ Even though this was a significant drop from just around 61,000 people in 1984, when combined with the associated public sector workforce the figure is huge. In 1997 there were 35,000 nuclear technicians and 60,000 non-technicians in private institutions, and 7,000 researchers and staff at public institutions and universities. Furthermore, 760 students graduate every year with a major in nuclear technology. ${ }^{61}$ These numbers show the strength and the depth of the industry.

According to Koide and Adachi, the Japanese government has given an annual subsidy to the industry of around $¥ 500$ billion $^{62}$; this goes to companies that conduct and develop nuclear research and technology. In return, the Japanese nuclear industry in 2005 gave a total of $¥ 83.2$ billion in grants to Japanese government research institutions such as Japan Atomic Energy Agency (JAEA) and others. ${ }^{63}$ The JAEA is the government funded research and administrative institution within the Japanese government that conducts nuclear related research. The subsidy flows from the government to industry, and the grants from industry to government research institutions indicate the influential power of the JAIF itself, a matter that has not generally been acknowledged.

The last feature is the influence and strength of the major companies engaged in the nuclear industry. Some of the companies are former Zaibatsu (industrial and financial conglomerates

\footnotetext{
${ }^{58}$ Dai 48kai (2006) Genshiryoku sangyō jittai chōsa no gaiyō (Outline of research of Japan's nuclear power industry), by Japan Atomic Industrial Forum, Inc., 29 February 2008. The data is available at: http://www.jaif.or.jp/ja/news/2008/48th-jittaichousa press-release.pdf, (accessed 4 June 2008).

${ }^{59}$ H. Koide and A. Adachi, Genshiryoku to kyōzon dekiruka (Can we live together with nuclear power), Kamogawa shoten, Kyoto, 1997, pp. 135 - 136.

${ }^{60}$ Dai 48kai (2006) Genshiryoku sangyō jittai chōsa no gaiyō (Outline of research of Japan's nuclear power industry).

${ }^{61}$ Koide and Adachi, Genshiryoku to kyōzon dekiruka (Can we live together with nuclear power), p. 136.

${ }^{62}$ Ibid., p. 136.

${ }^{63}$ Nihon no genshiryoku sangyō no gaiyō (Summary of Japan's nuclear power industry), by Japan Atomic Industrial Forum, October 2007, http://www.jaif.or.jp/ja/joho/press kit2007-sangyo.pdf, (accessed 4 June 2008).
} 
from the pre-World War II period) such as Mitsui, Mitsubishi and Sumitomo. These companies would appear to be the driving force behind Japan's nuclear industry.

The relationship between the nuclear industry, big business and the government is indeed close. There is an interlinking partnership in the planning, building, and the operation of nuclear plants, and the government continues to support this industry. An example of this close relationship is shown with Mitsubishi Heavy Industries (MHI): it was chosen by the government as the founding corporation to develop FBRs in Japan. The government selected MHI to develop the new generation FBRs and the company plans to build a unit by 2008 and to introduce a commercial reactor by $2025 .{ }^{64}$ As FBRs are considered to be the key to Japan's future nuclear power program, the close alliance between the government and MHI is understandable. According to 'World Nuclear News', the Japanese government allocated $¥ 13$ billion (US\$109 million) in 2008 for the development of the next generation reactors. ${ }^{65}$

The Japanese nuclear energy companies have been very active in expanding their prosperous businesses. In October 2006, Toshiba Corporation purchased a 51 percent share of Westinghouse USA for the sum of US\$5.4 billion (¥621 billion). ${ }^{66}$ Toshiba is looking to further expand into some parts of Asia, particularly into China. Japan's nuclear technology is indeed enabling its corporations to pursue nuclear power development opportunities abroad.

Finance is the key ingredient for influence in the nuclear industry power game. The Japanese Communist Party revealed that MHI had received METI research grants of around $¥ 10.1$ billion for research in 2004 . It further revealed that in 2003 MHI had donated about $¥ 10$ million as Seiji kifukin (political donations) to the Liberal Democratic Party (LDP). ${ }^{67}$ By

\footnotetext{
64 “Mitsubishi to develop Japan's next fast breeder reactor”, World Nuclear News, 18 April 2007, http://www.world-nuclear-news.org/newNuclear/180407-

Mitsubishi to develop Japan's next fast breeder rector.shtml, (accessed 18 January 2008).

65 “Mitsubishi to develop Japan's next fast breeder reactor”, World Nuclear News, 18 April 2007, http://www.world-nuclear-news.org/newNuclear/180407- Mitsubishi to develop Japan's next fast breeder rector.shtml, (accessed 18 January 2008).

${ }_{66}^{66}$ "Toshiba, bei WH baish̄u wo happyō (Toshiba report purchase of WH of USA)", Yomiuri shimbun online, 7 February 2006, http://www.yomiuri.co.jp/atmoney/mnews/20060207mh03.htm, (accessed 1 April 2008).

67 "Kenkyz kaihatsu hi (Research and development subsidy)" in Akahata Shimbun, by Japanese Communist Party, 29 August 2005, http://www.jcp.or.jp/akahata/aik4/2005-08-29/2005082901 04 1.html, (accessed 22 January 2008).
} 
comparison to the MHI grants, Japan's five million medium and small companies only received $¥ 8.9$ billion in 2003 . ${ }^{68}$ The majority of companies who received the METI’s research grants are companies that are not only big, but are also involved in the nuclear power industry. It could be said that the JAIF itself represents Japan's nuclear industry as a whole in its approach to collaboration and negotiation with the government, and to decisions that influence the government policy. That the Japanese LDP government has a close involvement with the nuclear industry was made clear by a report in the major Japanese newspaper Mainichi Shimbun on 7 April 2003 by Tetsuya Iida, the head of Kankyō enerugī seisaku kenkyūshō (Institute for Sustainable Energy Policies), a non-profit organization independent of the Japanese government and industry that researches energy issues in Japan. Iida argued that Japan's nuclear energy policy has been hijacked by the nation's strong believers in nuclear power, the LDP's nuclear power advocate members (zoku); they collaborated with the electric companies and their industries, and the METI, to promote further nuclear power to favor their vested interests, even though the policy saddles the Japanese public with a huge financial burden. ${ }^{69}$ Japan's nuclear power policy also places a financial burden on future generations, as well as creating the potential environment hazard that goes with nuclear power.

\section{Ethical concerns}

With the increase in the number of nuclear power plants there have also arisen concerns over the ethics that are associated with that form of electricity generation. Nuclear-related issues attract a broad range of views from scholars, researchers, politicians and environmental groups. However, there has been very little discussion in those debates based on a philosophical perspective. The philosopher Robert E. Goodin made the point that philosophers do not need to make apologies when participating in discussions of nuclear energy issues. ${ }^{70}$ The Japanese government has put forward a number of reasons to justify using nuclear power, but if there is an absence of ethical consideration then there is an imbalance in perspectives. An ethical

\footnotetext{
68 "Kenkyū kaihatsu hi (Research and development subsidy)".

${ }^{69}$ Kankyō enerugī seisaku kenkyūshō, http://www.isep.or.jp/kiji/kanko/mainichi030407.html, (accessed 31 March).

${ }^{70}$ R. Goodin, Political theory and public policy, University of Chicago Press, Chicago, 1982, p. 187.
} 
judgment of a nuclear energy policy is built on three pillars: a consideration for the environment, the consequences for future generations, and a focus on sustainability. These three elements (Figure 3) not only apply to a nuclear energy policy, but also to other policies such as whaling and forestry. The elements are based on environmental ethics, both Western and Japanese; sustainability for future generations is the core ethic. Japan's nuclear power policy has, however, been shaped by the nation's nuclear industry, aided by an accommodating rather than a regulating government. The industry has the responsibility of ensuring sound management practices, along with the government's role of policing it, in order to protect the environment. Some of the concerns about Japan's nuclear power policy will now be explored.

Figure 3: The three pillars of ethics in the use of nuclear energy

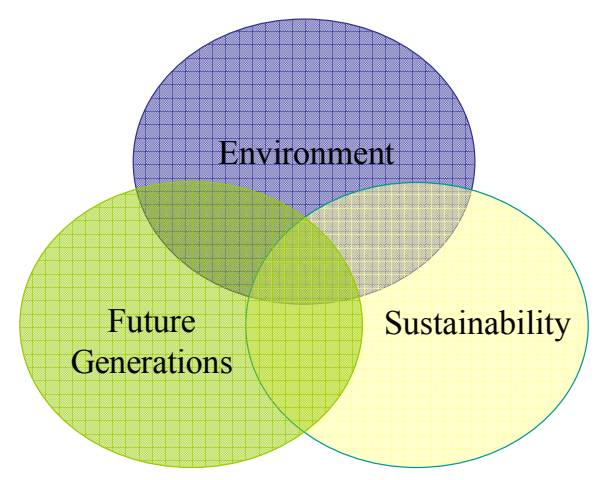

Compiled by the author

4.1. The focus of Japan's nuclear energy policy.

The Japanese government believes, and wants the public to believe, that using nuclear power is the best method of electricity generation for the country. A supposed advantage put forward by the government is that nuclear power plants do not emit carbon dioxide and thus this process does not contribute to global warming. As Japan is strongly committed to climate 
change issues, on the face of it this argument appears convincing. However, in the overall picture of using nuclear power the reality is that in the multiple operations from mining uranium to preparing it for reactor fuel, there are major carbon dioxide emissions. To that must be added Taylor's point that although nuclear energy is known as clean energy, its use will have only a modest effect on carbon dioxide emissions. ${ }^{71}$ Three ethical concerns regarding the policy focus need to be looked at.

The first is that the policy is driven by commercial interests. As mentioned in the previous section, the Japanese nuclear power industry is dominated by the country's big businesses which appear to have strong control over the direction of the policy. The government attempts to justify its development of the nuclear power program on the grounds that it is for the sake of energy security. The government is imposing its will on its citizens who are the ones who must bear the associated risks. The point of whether the policy is of direct benefit to the Japanese public has received only little scrutiny. Little ethical consciousness is shown in a policy driven by big business.

The second concern is that the policy discounts intergenerational interests. The significance of a consideration of the effects of policies upon future generations is clearly stated in the United Nation's statement on Sustainable Development. Principle 3 states that "the right to development must be fulfilled so as to equitably meet developmental and environmental needs of present and future generations." Sustainability has become a metaphor for environmental issues in a broad range of policy initiatives. Leslie Paul Thiele believes that the imperative of sustainability is a future-focused sensibility and is intrinsic to environmentalism. ${ }^{72}$ An examination of Japanese government White Papers on nuclear power reveal a focus on economic benefits rather than on social benefits. Japan's nuclear power policy gives details of an energy security plan for the supply of sustainable energy but it does not mention the interests of coming generations. In its concern with energy security, the policy fails to take into consideration the future social and environmental costs.

\footnotetext{
${ }^{71}$ Taylor, "Living without nuclear energy", in M. Kaku and J. Trainer (eds.), Nuclear power, both sides: the best arguments for and against the most controversial technology, p. 158.

${ }^{72}$ L. Thiele, "Limiting risks: environmental ethics as a policy primer", Policy Studies Journal, vol. 28, no. 3, 2000, p. 544.
} 
The final concern is the lack of public participation in policy formulation. The main focus of the policy is towards economics and power security and as a result most consultation takes place with 'big business'. It is extremely important that the public voice is heard, particularly when it is most affected by the government's decisions. Goodin emphasized the point that public participation in relation to democratic decision making is crucial. ${ }^{73}$ Lisberel noted that there is public participation in Japan with respect to the sitting and construction of nuclear facilities. ${ }^{74}$ However, McCormack used the instance of the Rokkasho nuclear facility to point out that in 1985 local government officials, faced with increasing debt, found it difficult to oppose plans generated in Tokyo; in 2000 they accepted a $¥ 240$ billion debt bail out through tax payer money. ${ }^{75}$ He further stated that the government bureaucracy has indulged the nuclear industry with trillions of Yen. The industry has not been driven by market forces nor, most importantly, by democratic consensus. ${ }^{76}$

Governments often employ a utilitarian approach in public policy making, but Goodin questions whether that approach is the best method. He argues that the utilitarianism theory is one that has to maximize preference satisfaction across all possible preferences and all possible people. ${ }^{77}$ If the Japanese government uses the argument of utilitarianism to justify operating more than 50 nuclear power plants, and plans to build a further dozen in the name of energy security, it raises the question as to which section of the community receives the greater benefit, Japanese industry or the Japanese public. Japan's nuclear power policy does not deliver an equal distribution of benefit: it greatly favors the business sector.

\subsection{Nuclear waste}

Unlike the conventional sources of energy of coal and crude oil, and the newly developed sources of wind, geothermal, and solar, nuclear energy confronts present and future

\footnotetext{
${ }^{73}$ Goodin, Political theory and public policy, p. 202.

${ }^{74}$ H. Lesbirel, NIMBY Politics in Japan, energy sitting and the management of environmental conflict, p. 38.

${ }^{75}$ G. McCormack, Client State, Japan in the American Embrace, Verso, London, 2007, p. 181.

${ }^{76}$ Ibid., p. 182.

${ }^{77}$ Goodin, Utilitarianism as a public philosophy, p. 3.
} 
generations with the dangerous element of radioactive waste. Lewis Roberts stated the principle that the significant hazard of nuclear waste should not be imposed on future generations. ${ }^{78}$ This element of the nuclear cycle raises fundamental questions of risk and responsibility. The disposal of nuclear waste is an ethical issue as it poses a burden on future generations and on the environment. The ethical consequence of using nuclear energy that serves only present day needs has not been addressed by the Japanese government, the nation's nuclear scientists, or Japan's nuclear industry.

Nuclear waste can be classified into two types. The first is high level-waste (HLW) that arises from spent fuel in power or weapons-production reactors, and is characterized by a mix of intensely radioactive fission products. The other type is low-level waste (LLW) which comes from commercially operated reactors and is characterized by low radioactivity. ${ }^{79}$ The much higher hazard is HLW which is treated in Japan by combining it in liquid form with molten glass; it is then poured into stainless steel canisters where it solidifies. Each canister is 1.3 meters long by 40 centimeters in diameter with a total weight of about $500 \mathrm{~kg}{ }^{80}$ The Japanese government coordinates with the AEC to handle the important issue of radioactive nuclear waste. The Japanese method of storing these canisters is to freeze them for around 40 years and then to bury them in safe underground storage. ${ }^{81}$

As mentioned earlier, the fundamental ethical issue of nuclear waste is that it leaves heavy responsibilities and liabilities onto coming generations. While the Japanese government highly values technological advancement to improve energy production and efficiency, this advancement has not reduced the burden of nuclear waste. The accumulated number of canisters is enormous. Since 1995 Japan has requested that its spent fuel be reprocessed abroad and that the waste to be then returned and stored at an HLW storage centre. As of March 1998, there were 128 HLW canisters stored in Japan and 3,500 canisters are expected

\footnotetext{
${ }^{78}$ L. Roberts, "Case study: nuclear power", in S. Berry (ed.), Environmental dilemmas: ethics and decisions, Chapman and Hall, London, 1993, p. 94.

${ }^{79}$ R. Wolfson, Nuclear choices, revised edition, The MIT Press, Cambridge and London, 1995, p.241.

${ }^{80} \mathrm{Ko}$ rebel hōshasei haikibutsu no shobun ni tsuite (About disposal of high level radioactive waste), The Agency of Natural Resources and Energy in the Ministry of Economy and Industry, 2001-2002, p. 3.

${ }^{81}$ Genshiryoku kyō soshite ashita (Nuclear power today, and tomorrow), The Agency of Science and Technology, December 1998, p. 22.
} 
to be returned to Japan over the next 20-30 years; stored LLW will amount to 490,000 barrels (a barrel equals 200 litres). ${ }^{82}$ It follows that as more nuclear reactors are brought on line, a greater amount of radioactive waste will be produced. The METI reported in May 2001 that 575 canisters were stored in Japan; it further reported at the end of 2002 that Japan possessed approximately 1,400 of them. ${ }^{83}$ A question naturally arises, where are the other 800 canisters stored?

A report from the AEC revealed that on top of the 15,500 HLW canisters that had been manufactured by 2001 , there would be an additional 1,100 to 1,400 produced annually, so that by 2020 there would be 40,000 of them stored in Japan. ${ }^{84}$ There are concerns not only for the problem of the physical storage of the waste, but also for the costs of storing it. In 2002, the AEC reported that the cost of the fabrication of the canisters and their storage is about $¥ 3$ trillion. $^{85}$ It should be noted that the Japanese method of storing nuclear waste is by vitrification and that that method does not allow for the possibility of future reprocessing.

These figures and costs demonstrate that the HLW produced from nuclear reactors carries a very high financial, security and ethical responsibility. The Japanese government's Nuclear White Paper emphasized future research and development, but neglected the ethical responsibility of nuclear waste, particularly HLW. In 2006 and 2007, whilst the allocation of $\$ 90$ million for HLW remained very much the same, the allocation for FBR development doubled from $\$ 50$ million to $\$ 100$ million. ${ }^{86}$

\footnotetext{
${ }^{82}$ Genshiryoku kyō soshite ashita (Nuclear power today, and tomorrow), pp. 23 - 24.

${ }^{83}$ Ibid., p. 3.

${ }^{84} \mathrm{Kō}$ reberu hōshasei haikibutsu shobun no gaiyō chōsha chiku no kōbo ni tsuite (About public offering of outline of research district of high level radio active waste disposal), The Atomic Energy Commission, Japan, 24 December 2002, http://www.aec.go.jp/jicst/NC/iinkai/teirei/siryo2002/siryo50/siryo3.pdf, (accessed 6 February 2008). ${ }^{85}$ Ibid.

${ }^{86}$ Nuclear related budget, 2006 Nuclear White Paper of Japan, http://www.aec.go.jp/jicst/NC/about/hakusho/hakusho2006/siryo32.pdf, (accessed 4 February 2008).
} 


\subsection{Plutonium}

The possession and stockpiling of plutonium has always been controversial. With Japan operating 55 plants in 2008 and a further 10 planned, its accumulation of plutonium from the reactors poses a serious problem. The AEC reported that the Japanese plutonium stockpile at the end of 2004 was 43.1 tons, an increase of 2.4 tons from $2003 .{ }^{87}$ Of further concern is that in addition to having one of the world's largest stocks of potential weapons grade plutonium $(45,000 \mathrm{~kg})$, Japan also has advanced missile technology. ${ }^{88}$

Japan's stockpile of plutonium raises questions of ethics as the country continues to produce and accumulate this hazardous substance. However, the Japanese government views the situation quite differently as it sees great advantages in utilizing the byproduct in plutonium fuelled reactors. The FBRs produce plutonium during their operation and so provide the core material for Japan's future NPP; by using this type of reactor Japan can be virtually self sufficient in fuel resources for electricity production. Japan's pro-nuclear power groups, local and central governments, and the nuclear related industries, are enthusiastic supporters of the use of plutonium. The use of this fuel creates additional hazards and costs, an element that the government ignores.

A major criticism of FBR's is that their operating costs are much higher than in reactors using uranium dioxide fuel. ${ }^{89}$ Japan has its 'Monju' FBR plant in Fukui prefecture. Construction of the plant started in 1985 and was completed in 1991; it uses MOX fuel (a blend of oxides from plutonium and natural uranium). FBR's are associated with many problems, such as the great difficulties associated with their operation, and the accumulation of plutonium. Monju commenced generating electricity in August 1995 but four months later it was closed down due to a leakage of sodium. ${ }^{90}$ It was expected that it would restart sometime in 2008 but, as

\footnotetext{
87 “Japan's plutonium stockpile tops 43 tons", by Science, physics, tech., and nano news, 8 September 2005, http://www.physorg.com/news6316.html, (accessed 18 January 2008).

${ }^{88} \mathrm{~F}$. Barnaby and S. Burnie, Thinking the unthinkable, Japanese nuclear power and proliferation in East Asia, Oxford research groups and Citizen's nuclear information center, 2005, p. 6.

${ }^{89}$ Barnaby and Burnie, Thinking the unthinkable, Japanese nuclear power and proliferation in East Asia, p. 10.

${ }^{90}$ Genshiryoku, kyo soshite ashita (Nuclear power, today and tomorrow), Agency of Science and Technology, 1998, p. 19.
} 
McCormack noted, although $¥ 600$ billion yen had been spent on it up to May 2005, it "had yet to light a single light globe; it is scheduled to be commercialized by 2050 ". 91

According to Jun Tateno, operating a light water reactor for one year yields about $300 \mathrm{~kg}$ of plutonium and, as a consequence, more than 10 tons of plutonium are created annually from 51 power plants. ${ }^{92}$ The Japanese government reported that after the Monju restarts its operation, it expects that it will need about $100 \mathrm{~kg}$ of plutonium for further research and development. ${ }^{93}$ The Japanese Citizen's Nuclear Information Center estimated that there is 367 $\mathrm{kg}$ of plutonium stockpiled at Monju facility, and about $10 \mathrm{~kg}$ in the reactor itself. ${ }^{94}$ Japan's plutonium stockpile is not confined to Japan as it has consignments for reprocessing in the United Kingdom and in France; as of 2000, a total of about 32 tons of plutonium will be returned from these countries. ${ }^{95}$ According to the AEC, there will be about 85 tons of separated plutonium, either in Japan or abroad, under commercial contracts by $2010 .{ }^{96}$

Barnaby and Burnie revealed in 2005 that Japan had one of the largest stocks of weapons usable plutonium in the world and, as mentioned, a most advanced missile technology ${ }^{97}$ This has raised the spectre of a military capability both at home and abroad. Some experts estimate that as little as $8 \mathrm{~kg}$ of reactor-grade plutonium is needed to produce a 20 -megaton bomb. ${ }^{98}$ This means that Japan is capable of producing about 4,000 of these bombs from just the reprocessed plutonium coming back from the United Kingdom and France alone. Japan's plutonium stockpile is already a strategic asset ${ }^{99}$ and this again raises the question of the ethical element in its NPP.

\footnotetext{
${ }^{91}$ McCormack, Client State, Japan in the American Embrace, p. 185.

92 J. Tateno, Hairo jidai ga hajimatta, kono genpatsu wa iranai (Era when the extinction of nuclear power plants began, we don't need these plants), Asahi Shimbun sha, Tokyo, 2000, p. 239.

${ }^{93}$ Agency of Natural Resources and Energy, Kangaeyō, Genshiryoku (Think about nuclear power), 2002, p. 18.

${ }^{94}$ Asahi Shimbun, 22 March 2000

${ }^{95}$ E. Johnston, "Monju ruling infuriates plaintiffs", Japan Times, 22 March 2000, http://www.japantimes.co.jp/news/news3-2000/news3-22.html, (accessed 12 May 2000).

${ }^{96}$ K. Kaneko, "Japan needs no umbrella", The Bulletin of the Atomic Scientists, vol. 52, no. 2, March/April, 1996, p. 47.

${ }^{97}$ Barnaby and Burnie, Thinking the unthinkable, Japanese nuclear power and proliferation in East Asia, p. 6.

${ }^{98}$ E. Johnston, "Monju ruling infuriates plaintiffs", Japan Times, 22 March 2000, http://www.japantimes.co.jp/news/news3-2000/news3-22.html, (accessed 12 May 2000).

${ }^{99}$ Barnaby and Burnie, Thinking the unthinkable, Japanese nuclear power and proliferation in East Asia, p. 10.
} 


\subsection{Nuclear weapons}

Acquiring nuclear weapons capability raises not only ethical concerns, but also places a question mark over human responsibilities to planet earth. The ethical argument over nuclear weapons is not just an issue for philosophers; discussion on the subject encompasses a range of thinkers from political philosophers to environmental ethicists. Goodin argued strongly that the use of nuclear reactors and their resultant by-products impose irreversible obligations. ${ }^{100}$ Environmental philosopher Clare Palmer said that nuclear power generation that produces highly toxic waste with its ensuing storage problems, and the possible use of this waste for nuclear weapons manufacture, raise the most fundamental ethical questions. ${ }^{101}$ Frank Barnaby and Shaun Burnie stated that Japan, with its technology and plutonium stockpile, could build advanced nuclear weapons within six months. ${ }^{102}$

As Japan has been the only country to have experienced the effects of atomic bombs, the possession of nuclear weapons is a sensitive subject among many of its people. Japan has endorsed at least three binding accords that confirm that any activities with nuclear weapons are unethical.

The first accord mentioned in the earlier section on Japan's nuclear power policy development is the 1955 AEBL. It is the foundation of the country's nuclear power policy for nuclear research and development. Article 2 in the law emphasizes that Japan's nuclear power is to be used exclusively for peaceful purposes.

The second accord of 1969, Hikaku Sangensoku (Three Non-Nuclear Principles), is a policy by which the Japanese government prohibited the possession, the manufacturing, and the introduction of nuclear weapons into Japan. The late 1960s was a difficult period for Japan as Prime Minister Eisaku Sato had to deal with problems ranging from domestic environmental pollution disasters to re-establishing diplomatic relations with other countries. During that

\footnotetext{
${ }^{100}$ Goodin, Political theory and public policy, p. 210.

${ }^{101}$ C. Palmer, Environmental ethics, contemporary ethical issues, ABC-CLIO Inc., California, 1997, p. 86.

${ }^{102}$ Barnaby and Burnie, Thinking the unthinkable, Japanese nuclear power and proliferation in East Asia, p. 10.
} 
decade, as Japan expanded its nuclear power development and its economy, the Hikaku Sangensoku pledged that Japan would remain a non-nuclear weapons country. The government has maintained that commitment and no changes have been made to that principle. Subsequent Prime Ministers have firmly maintained the government's position as a nonnuclear weapons country; this commitment is reaffirmed annually at both the Hiroshima and Nagasaki Peace Memorial Ceremonies.

The final accord is the Non-Proliferation Treaty of nuclear weapons (NPT). The NPT was established by the United Nations in 1968 with the aim of not only preventing the spread of nuclear weapons, but also of promoting the peaceful uses of nuclear power. The Japanese government ratified it and in 1976 reconfirmed that Japan was not going to arm and would follow the regulations of the AEBL and the Hikaku Sangensoku.

The three accords have remained very much the same since the government endorsed them. In spite of this, Japan's plutonium stockpile raises questions over government morality regarding nuclear weapons. Tateno, for example, emphasized that plutonium is a material for nuclear armaments and that plutonium taken from light water reactors could make low quality weapons. $^{103}$ Japan's concentration on FBR plants, its technological sophistication, and its accumulation of plutonium, leave no doubt that the country has the ability to build and use nuclear warheads. Nuclear weapons are unquestionably unethical, yet many countries possess them.

In spite of the Japanese government's firm commitment to be a non-nuclear weapons country and its signing of the previously mentioned agreements, some leading Japanese politicians have suggested a case for Japan to possess these weapons for self-defense purposes. These politicians have shown a rather nationalistic and provocative attitude regarding the possession of nuclear weapons. Yasuhiro Nakasone, a former Japanese Prime Minister (1982-1987), said that obtaining defensive nuclear weapons would not violate its Peace Constitution. ${ }^{104}$ Shinzo

\footnotetext{
${ }^{103}$ Tateno, Hairo jidai ga hajimatta, kono genpatsu wa iranai (Era when the extinction of nuclear power plants began, we don't need these plants), p. 239.

${ }^{104}$ R. Manning, "Rethinking Japan's plutonium policy: key to global Non-proliferation and Northeast Asian Security", the Journal of East Asian Affairs, vol. IX, no.1, Winter/Spring 1995, p. 122.
} 
Abe, Prime Minister from 2006 to 2007, "surely had North Korea in mind when he said that it is 'not necessarily unconstitutional' for Japan to develop a nuclear deterrent". ${ }^{105}$ A past leader of the Democratic Party of Japan, Ichiro Ozawa, added to the concern about Japan's policy stance when he said that the country could easily produce thousands of nuclear weapons using plutonium recovered from its commercial nuclear reactors. ${ }^{106}$

Japan's highly advanced technology sector, and its ambitious nuclear industry, make this scenario quite possible. Goodin has said that "nuclear proliferation is irreversible as once nations acquire the capacity to build nuclear weapons, they have it forever". ${ }^{107}$ The production and possession of nuclear weapons, under whatever justification, is fundamentally unethical.

\subsection{Environmental concerns}

The environmental advantages of nuclear power energy have often been overstated: the significant hidden costs to the environmental have been virtually neglected by Japanese bureaucrats, scientists and scholars.

Clean and green nuclear power generation is heralded as one of the Japanese government's global environmental initiatives, but this is not what drives the government. This is only lip service to the environment; its main goal is to have a reliable and available source of energy that will sustain its economy, and the 55 nuclear power plants operating in the country attest to that. The pillar of Japan's global environmental initiatives is sustainable development and this should also apply to the country's nuclear power policy. Nuclear power inevitably raises environmental issues: the United Nations Conference on Environment and Development at Rio de Janeiro in 1992 stated it very clearly. Principle 4 reads: "In order to achieve sustainable development, environmental protection shall constitute an integral part of the

\footnotetext{
105 "The son also rises in Japa" The Observer, Sunday 24 September 2006.

106 "Japan can construct nuclear bombs using its power plant plutonium", by Nuclear Control Institute, Washington, D.C., http://www.nci.org/02NCI/04/pr040902.htm, (accessed 18 January 2008).

${ }^{107}$ Goodin, "No moral nukes", Ethics, p. 436.
} 
development process and cannot be considered in isolation from it". ${ }^{108}$ That numerous accidents at nuclear facilities have caused environmental damage demonstrate that a strong ethical consideration is needed in nuclear power plant developments. Their location is closely tied to the sustainability of the amenity of the local environment.

Some examples of unusual environmental phenomena have been found near nuclear power facilities in Japan. Manabu Akaike and Isao Fujii reported that near the Hamaoka nuclear power site in Shizuoka prefecture, animals and plants with abnormalities were found, e.g. a turtle with 2 heads and 8 legs, and strangely shaped clover with 5 or 6 leaves; the ratio of abnormality in 2,500 samples collected was 1.72 percent. ${ }^{109}$ Although there is no proof that these phenomena were caused by radiation from the nuclear power generators, it should be noted that it is not uncommon to see such abnormalities in animals and plants near them. The Japanese government responded to the concerns of communities near power plant sites by applying the 1975 's Three Laws. This is an economic arrangement in which the government gives a subsidy to the local community in return for accepting a nuclear power plant. The Three Laws are meant to improve the nuclear industry, the power plants, and the surrounding communities, but very little consideration is given in the laws to the environment. Furthermore, a nuclear policy that involves an unequal distribution of benefits and burdens among various social groups dependent on geographic location cannot be morally justified. ${ }^{110}$ The location of nuclear power plants must also take into consideration non-human beings.

The 1986 Chernobyl accident illustrated just how far environmental pollution and food contamination can extend. Radioactive contamination was recorded in several places in Japan; iodine was found in the rain in Chiba and Fukui prefectures, and it was also found in lettuces and cabbages growing there. ${ }^{111}$ Considering how even small accidents can have a

\footnotetext{
108 "Rio Declaration on Environment and Development", United Nations Environment Program, UNEP , June 1992, http://www.unep.org/Documents.Multilingual/Default.asp?documentID=78\&articleID=1163 (accessed 29 May 2008).

${ }^{109}$ M. Akaike and I. Fujii, Yumori no sentaku (The choice for warmth), TBS Buritanika, Tokyo, 1998, p.20.

${ }^{110}$ H. Damveld and R. Berg, Nuclear waste and nuclear ethics, January 2000, p. 15, http://www.nuclearfiles.org/menu/key-issues/ethics/issues/scientific/nuclear waste ethics.pdf, (Accessed 29 May 2008).

${ }^{111}$ Nihon mirai tanken tai (ed.), Genpatsu tengoku no honto to uso (What is the truth or lies in Japan's nuclear power plants), Puranetto Shuppan, Tokyo, 1999, P.90.
} 
devastating effect, it is hard to see how the desire of the present generation to have greater supplies of electricity generated by nuclear reactors can be ethically justified. Environmental concerns are not just located near nuclear power plants. Arthur Johnston and Stewart Needham stated that uranium mining is associated with radon, a radioactive gas released at mine sites at concentrations substantially above normal background rates, and that this can lead to an increased radioactive exposure to the public. ${ }^{112}$ This applies to the flood plains in Australia's Kakadu National Park where there is uranium mining; the area is listed under the Convention on Wetlands of International Importance. ${ }^{113}$ Much of the land there has been recognized as a part of the traditional estate of the Aboriginal people of the region. ${ }^{114}$ Even though Japan does not have direct responsibility for the environment in foreign countries, its government has a causal responsibility as Japan's nuclear power program depends on foreign sourced uranium.

\section{Conclusion}

Japan has embarked on an ambitious nuclear energy development program, but it raises a number of ethical questions that encompass the areas of principled commercial enterprise, legitimate scientific research, as well as sociopolitical and philosophical values.

As Japan is singularly lacking in natural reserves, it needs to import vast amounts of energy resources to sustain the high standard of living it has chosen to enjoy; this decision alone demonstrates questionable ethical integrity. Whilst the direct cost to consumers of nuclear generated electricity may be attractive, what is not taken into account is the vast amount of tax payer's money that has been paid through the government's support of the nuclear industry. The morality of the government's NPP is compromised by the intimate relationship between business interests, the former ruling LDP, and government bureaucracies. The LDP controlled

\footnotetext{
${ }^{112}$ Nihon mirai tanken tai (ed.), Genpatsu tengoku no honto to uso (What is the truth or lies in Japan's nuclear power plants), p.18.

${ }^{113}$ A. Johnston and S. Needham, Protection of the environment near the Ranger uranium mine,_Environment Australia, Supervising Scientist report 139, Canberra, 1999, p.V.

${ }^{114}$ Ibid., p.V.
} 
government rewarded 'nuclear big business' with lucrative projects, the largess filtering down to local governments and ensuring continued support for its party members. Ethical considerations are put aside in the quest for political and economic gain, and for corporate opportunities.

The most unethical aspect of the nuclear policy is the burden that it places on future generations. The advantages of operating nuclear power are realized over an incredibly short period of time in comparison to the time needed for the radioactive waste to decay to safe levels; coping with these hazards will come at a tremendous cost to future generations who have never received the benefits. The government has become heavily dependent on the NPP which mortgages and endangers the wellbeing of succeeding generations; such a policy can only be described as irresponsible and unethical.

The next chapter that examines the domestic forestry and timber trade policy treads a similar path to that followed in the present chapter. An industry dominated triangle controls the policy at the expense of others, be they Japanese foresters or overseas forest dwellers. Japan's forestry policy presently encourages the preservation of its own forests whilst making vast demands on foreign ones. 


\section{CHAPTER SIX: Case study 3}

\section{DOMESTIC FORESTRY AND TIMBER TRADE POLICY Practices, principles, ethics}

Japan is one of the most highly forested nations in the world with a woodland covering of around 70 percent of the total land mass: of this 40 percent consists of plantations ${ }^{1}, 31$ percent is national forest, 11 percent is held by local governments, and 58 percent is privately owned. ${ }^{2}$

This chapter questions the ethics of Japan's forestry and timber trade policy. From the 1980s the domestic forestry policy has been influenced by the government's global environmental initiatives (discussed in Chapter 3); it has shifted from ensuring a continuing supply of domestic timber for industry, to protecting its forests for 'green' purposes. Japan sources vast amounts of timber from abroad and the tremendous environmental degradation caused to the forests of the timber supplying countries has given rise to social outcries over the resultant ecological destruction. Japan's forestry policy has been examined by scholars such as Peter Dauvergne in his 1997 book, Shadows in the Forests; in this he explored the politics of timber trading in Southeast Asia and the politics of Japanese businesses in that region. However, there has been little attention given to Japan's forestry and timber trade policies from an ethical perspective. In spite of global initiatives towards protecting the natural world, Japan's timber policy has a narrow focus on ensuring a sustainable supply of imported lumber. One of the nation's major concerns is sustaining its economic growth, but there is little awareness shown of the environmental impact that this activity has in the overseas countries that supply their natural resources to Japan.

This chapter consists of five parts. The first analyzes the development of Japan's forestry policy from the post war period; it shows how it was formed and how it developed. The

\footnotetext{
${ }^{1}$ M. Fujiwara, "Silviculture in Japan", Y. Iwai (ed.), Forestry and the forest industry in Japan, USB Press, Vancouver, 2002, p. 10.

${ }^{2}$ Y. Iwai, "Introduction", Y. Iwai (ed.), Forestry and the forest industry in Japan, p. XIV.
} 
second part examines Japan's timber imports, how they were coordinated and from where the timber was sourced. The third part looks at the uses Japan makes of timber. The fourth part investigates the main players in the Japanese forestry industry, and in the timber importing industry. The final part examines the philosophical aspect of Japan's forestry policy, and of its timber trading activity.

\section{The development of Japan's forestry policy}

The development of the policy can be divided into three eras; the period of increased timber demand (1950s-mid 1960s), the period of extreme demand (mid 1960s-mid 1980s), and the new approach period (the mid 1980s onwards).

\subsection{The period of increased timber demand (1950s-mid 1960s)}

Forests have always played an important part in the way of life of the Japanese, and timber has long contributed to traditional uses such as for house building and for fuel. Japan started plantation forestry at the end of the $17^{\text {th }}$ Century. ${ }^{3}$ Prior to 1920 and during World War II (WWII) the country was self sufficient in timber for housing. In the post war period there was an increased demand for timber and this demand accelerated greatly in the $1960 \mathrm{~s}^{4}$

At the conclusion of WWII Japan's foresters concentrated on silviculture (the study, cultivation, and management of forest trees) with the aim of making the most of their woodlands. Japan used the surplus labor from repatriated soldiers to initiate a strategy to establish extensive plantations. ${ }^{5}$ In order to revitalize timber production at that time, Japan focused on building a strong organizational backup to support the industry. The government took an important step by establishing two institutions to direct its forestry policy. The first in

\footnotetext{
${ }^{3}$ J. Iwamoto, "The development of Japanese forestry", in Iwai (ed.), Forestry and the forest industry in Japan, USB Press, Vancouver, 2002, p. 3.

${ }^{4}$ Iwai, "Introduction", p. XV.

${ }^{5}$ I. Fujikake, "Forestry labour", Iwai (ed.), Forestry and the forest industry in Japan, USB Press, Vancouver, 2002, p. 69.
} 
1947 was the Forestry Agency within the Ministry of Agriculture, Forestry and Fisheries (MAFF); this was designed to ensure the orderly management of national and privately owned forest land. The second, in 1949, was the establishment of a corporation named Nihon Ringyo Kyōkai (Japan Forestry Association (JFA)); its purpose was to support both the forestry and timber industries in Japan and to lobby government policy makers on its behalf. The JFA membership consists of more than 100 organizations from paper manufacturing companies to building associations. ${ }^{6}$

In 1953 the Forestry Agency announced its first strategic plan aimed at increasing timber production. Mitsuo Fujiwara pointed out that the Agency established a National Forest LongTerm Production Plan to produce timber from conifers; however, the practice of any kind of selection method was limited as Japan's forestry was based on the clear-felling technique. ${ }^{7}$

Demand for timber increased dramatically in the 1950 s and that period became a turning point for Japan's forestry and timber industry. The outbreak of the Korean War in1950 accelerated Japan's economic recovery. Included in this recovery was the need for timber in the construction industry; as a consequence, the price of lumber increased greatly in comparison to other commodities. The wood price index in Japan in 1952 was 100 , but by 1957 it had reached 154 and by 1961 it had almost doubled the 1952 price. ${ }^{8}$ Yoshiya Iwai and Kiyoshi Yukutake are of the opinion that in 1961 the government was so concerned that the high price of lumber might adversely affect the Japanese economy that "it decided to import roundwood, and to liberalize the trade in sawnwood and plywood by 1964 by reducing tariffs gradually". 9 An important dynamic at that time was that although the harvest from national forests was increasing, the domestic industry could not cope with the demand brought on by the country's remarkable economic growth; the difficult terrain where the forests were situated did not allow for modern efficiencies. Furthermore, the industry's fragmented and outdated operations were unable to adjust to changing demands; imported timber was able to be supplied in the quantity,

\footnotetext{
${ }^{6}$ Nihon Ringyō Kyōkai (Japan Forestry Association), available at; http://www.j-forestry.or.jp/teikan1.htm, (accessed 8 July 2008).

${ }^{7}$ Fujiwara, "Silviculture in Japan", p. 13.

${ }^{8}$ Y. Iwai and K. Yukutake, "Japan's wood trade", in Iwai (ed.), Forestry and the forest industry in Japan, USB Press, Vancouver, 2002, p. 245.

${ }^{9}$ Ibid., p. 245.
} 
quality, and sizes in line with new requirements. ${ }^{10}$ That, along with its tariff free advantage, made the lower priced imported timber more desirable, adding to the difficulties within the domestic industry.

1.2. Overseas timber: the extreme demand (mid-1960s to the mid-1980s)

At the beginning of the 1960s the Forestry Agency was faced with three main issues. One, the country's rate of timber self-sufficiency was continuing to fall; two, the volume of cheap imported timber was continuing to rise; and three, there was a drift of forestry workers away from villages to cities. Japan's domestic timber industry was simply unable to compete against the timber importing companies. The importers were able to ensure a steady supply of timber in the sizes that were now being used, whereas the small Japanese mills were producing their timber in outdated sizes (traditional Japanese houses had up to 200 different specifications $)^{11}$ and were not able to guarantee continuity of supply.

Due to the decline of the domestic forestry industry, in 1964 the Japanese government enacted the Basic Forestry Law (BFL). The purpose of the BFL was to increase forestry production, to improve national forests, and to advance the welfare of forestry workers. ${ }^{12}$ The Law defined the responsibilities of the central and local governments in relation to the national forests, and the forestry industry. It was significant in raising awareness not only on forestry issues, but also on environmental protection issues.

The BFL became the pillar of Japan's forestry policy direction. At the time of the Law's enactment, Japan's self-sufficiency rate in timber was around 70 percent, but by 1970 it had dropped to less than 50 percent and was continuing to fall (see Figure 1).

\footnotetext{
${ }^{10}$ Iwai, "Introduction", p. XIX.

${ }^{11}$ K. Ito, "Logging and log distribution", Iwai (ed.), Forestry and the forest industry in Japan, USB Press, Vancouver, 2002, p. 175.

${ }^{12}$ K. Matsushita \& K. Hirata, "Forest owner's association", in Iwai (ed.), Forestry and the forest industry in Japan, USB Press, Vancouver, 2002, p. 45.
} 
Figure 1: Japan's self-sufficiency rate for timber between 1955 and 2005

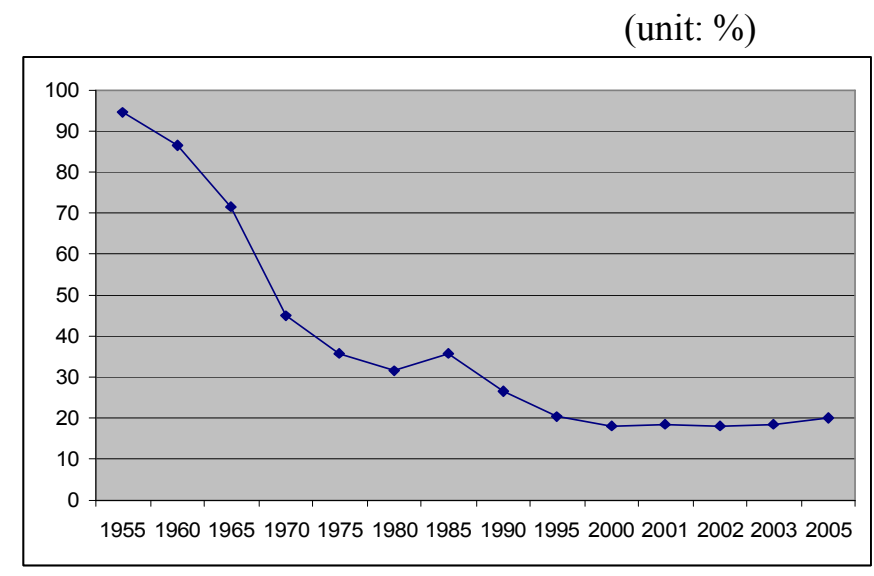

Source: Graph created by the author from information supplied by the Forestry Agency.

After the passing of the BFL, the Forestry Agency attempted to restore security to the industry by enacting a further three laws. The first in 1965 was the Village Promotion Law; it was designed to encourage the economic and social well-being of village life. The second in 1976 was the Forestry and Timber Industry Improvement Financial Assistance Law. The third in 1976 was the Forestry Industry Promotion Financial Assistance Provisional Law. The latter two laws were designed to financially assist Japanese forest owners in the improvement of their forestry practices; they were able to borrow 'interest free' money from their local governments who in turn were able to receive assistance from the central government. ${ }^{13}$ Both laws dealt primarily with the commercialization of timber production.

The 1970s was another defining decade for Japan's forestry industry. Environmental awareness at that time, both domestic and global, brought about a change of attitude among the Japanese towards their forests. The country began to pay more attention to the protection of the forests rather than to their productive capacity. The economic benefits that had been achieved by exporting domestic timber were eclipsed by the action of the large timber

\footnotetext{
${ }^{13}$ Kankei hōrei (Related laws), Forestry Agency in the Ministry of Agriculture, Forestry and Fisheries, http://www.rinya.maff.go.jp/seisaku/houritu.html, (accessed 15 July 2008).
} 
companies, which were able to import roundwood, process it, and then export the value added products.

When the second oil shock hit the Japanese economy in 1979, the government introduced the Regional Forest Policy; its aim was to coordinate regional forest operations and to promote logging, processing, and distribution. ${ }^{14}$ In spite of the attempts by the Government to revitalize and support the domestic industry, it struggled to survive.

During the 1960s and 1970s the domestic forestry industry became a casualty of the Government's economic policies. The rapid acceleration of the Japanese economy in the 1960s was achieved by a strong and determined trade policy; this had the effect of limiting the role that the Forestry Agency could play as it was only able to implement a general policy covering national and private forests. Although there were laws enacted to provide financial assistance to forest owners, the focus of the policy moved from production to protection. In the 1980s there were no new forestry laws or regulations and Japan's forestry policy remained much the same as it was in the 1970s. Shōji Mitsui stated that in the first half of the 1980s the forestry budget grew by only 3 percent over five years. ${ }^{15}$

\subsection{Japan's forestry policy: a new approach (the mid-1980s -)}

In the latter part of the 1980s, Japan's forestry received a boost as over a five year period the forestry budget grew by 21 percent. This increase was the result of the Baburu keiki (bubble economy) that the nation was experiencing. ${ }^{16}$ The increase in economic activity, along with sky high land and stock values, had a flow-on effect to government budgets that benefited forestry. However, the fiscal stimulus did not lead to better planning or results: "annual

\footnotetext{
${ }^{14}$ S. Mitsui, "National and regional forest policies", in Iwai (ed.), Forestry and the forest industry in Japan, USB Press, Vancouver, 2002, p. 147.

${ }^{15}$ Ibid., p. 147.

${ }^{16}$ Ibid., p. 148.
} 
revenue and expenditure calculations often allowed for harvesting operations but ignored the cost of growing stock". ${ }^{17}$

Environmental awareness reached a new level in the early 1990s and Japan's forestry policy took a further turn. For the first time Japan's Forestry White Paper acknowledged the relationship between global environmental concerns and forestry issues. Since the late 1980s an awareness of global environmental problems had become an important influence in guiding Japan's policies; the government now focused on forestry issues in the light of these concerns.

The most significant development for the forestry policy at that time was the revision of the BFL in 2001; it was the first time in 37 years that it had been amended. The law was renamed the Forests and Forestry Basic Law and was an acknowledgement by the government that it intended to emphasize the importance of sustainable forest management. The positive aspects of the new law were that they demanded an upgrading of the forestry industry, an enhancement of the forest biology and environment, and an improvement in the welfare of the foresters.

From the early 1990s the Forestry Agency initiated some new approaches. Three will be examined. The first followed an Agency announcement in a 1989 Forestry White Paper that it would use 'forestry diplomacy (林野外交)' where it stated clearly that the government would commit to forestry projects in developing countries. Japan offered expertise in forestry research and technology and dispatched experts and technicians to the Philippines, Thailand, Peru, Kenya, and to other developing countries. ${ }^{18}$ This type of diplomacy was very much based on technical assistance funneled through Japan's Official Development Assistance (ODA) programs. Furthermore, the Japan Bank for International Cooperation financed low interest, long term loans to the forestry sector in overseas countries. Between 1988 and 1999 the Forestry Agency assisted with 24 projects, mainly in afforestation ventures in the

\footnotetext{
${ }^{17}$ K. Matsushita, "National forest management", Iwai (ed.), Forestry and the forest industry in Japan, USB Press, Vancouver, 2002, p. 107.

${ }^{18} 1989$ Forestry White Paper by the Forestry Agency, http://www.maff.go.jp/hakusyo/rin/h01/html/index/htm, (accessed 24 September 2007)
} 
Philippines, Indonesia, India and Tunisia. ${ }^{19}$ The Agency, in line with other Japanese ministries, agencies, and departments, used overseas projects to promote Japanese technology.

The second initiative the Agency took was to implement the government's strategic approach towards revitalizing the domestic forestry industry. Two of the most intractable problems were the depopulation of forest villages and an ageing workforce: the average age of forestry workers in 2004 was 65 years. (See Figure 2) The decline of forestry activities persuaded many active workers to leave their villages for larger towns; this exodus compounded the forestry problems, creating dilemmas for other rural activities.

The central government's strategic approach was strengthened by the involvement of regional governments. As of June 2002, 115 villages, towns, and cities had initiated Sanson Shinkō (mountain village promotion) in order to entice city people to go and live in the mountain villages and towns. In 2002 the Agency initiated a project named Midori no koyō ( 緑の雇用: Green employment), an initiative to promote employment opportunities in the forestry industry. The regional governments' offered job opportunities and promoted the message of 'quality living’ to the city dwellers. The Forestry Agency requested $¥ 6.7$ billion in grants for its 2007 budget for Green employment, the purpose of which was to create more employment opportunities in the forestry region; ${ }^{20}$ this is an indication of how anxious the Agency was to bring about a return of people to the countryside and a return to a successful domestic forestry industry.

\footnotetext{
${ }^{19}$ The Forestry Agency, Shinrin, ringyō bunya no kokusai teki na torikumi (International contribution in forest and its industry), http://www.rinya.maff.go.jp/seisaku/sesakusyoukai/kaigi/con-3.html, (accessed 24 September 2007).

${ }^{20}$ Heisei 19nen do rinyachō kankei yosan gaisan kettei gaku no gaiyō (Related budget of the Forestry Agency 2007), the Forestry Agency, December 2006 http://www.rinya.maff.go.jp/puresu/h19-2gatu/rinseisin/0205s1.pdf (accessed 25 September 2007).
} 
Figure 2: The percentage of forestry workers aged over 65 between 1975 and 2004.

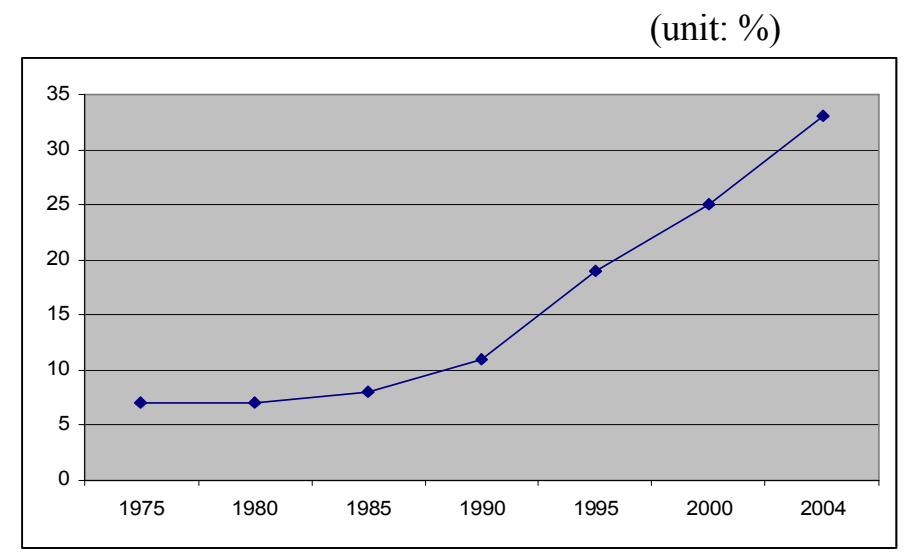

Source: Ringyō, Mokuzai sangyō no dōkō (Trends in the forestry and timber industry), from the Forestry Agency. ${ }^{21}$ Compiled by the author.

Due to the growing environmental awareness in Japan, the number of volunteers for forest husbandry has been increasing. The number of volunteer groups, including Non-Profit Organizations, was also growing, from 277 in 1997 to 1,863 in $2006{ }^{22}$ The Forestry Agency had established a 'volunteer support section' in order to encourage, and to provide assistance to these organizations. The government plan to encourage city dwellers to participate in forestry activities was significant in rejuvenating Japan's neglected forests.

The Agency's third approach was to establish regulations to prevent the trading in illegally logged timber. Japan set laws to verify the sustainability of the supplying forests, and to verify the legitimacy of timber imported into Japan. In April 2006, the Agency enacted a Law to promote so called 'green purchasing'; this law encouraged the purchase of timber that had been obtained legally and that had come from sustainable operations.

Japan's 2006 Forestry White Paper had two major themes; global environmental concerns and Japan's domestic timber industry. Despite this emphasis there had been little change since

\footnotetext{
${ }^{21}$ Ringyō, mokuzai sangyō no dōkō (The trend of the forestry and timber industry), The Forestry Agency, 2007 http://www.maff.go.jp/hitokuti/memo/memo5 4.pdf, (accessed 28 September 2007).

${ }^{22}$ Shinrin boranthia no genjyo (The current situation of forestry volunteers), the Forestry Agency, 2007 http://www.rinya.maff.go.jp/policy2/volunteer/con1.htm, (accessed 25 September 2007).
} 
1989 in the main agenda of the government paper. When Japan was enjoying the economic miracle of the 1970s, the domestic forestry industry was having difficulty adjusting to the changing conditions, but this was ignored. By 1993 logging costs were 28-52 percent of the auction price of the trees and this did not allow a sufficient margin for the costs of replanting and managing the forests. ${ }^{23}$ By April 2004, even though Japan had a forestry industry capable of sustaining an annual production of 4 billion $\mathrm{m}^{3}$, only 7 percent of mountain forest owners were selling their timber. ${ }^{24}$ Most forests would remain uncut and would progress from middle age to old age. For the first time in several generations, there was now sufficient tree pollen from mature trees around Tokyo to trigger allergies amongst residents.

The Japanese government put revenue from the domestic timber industry into the general account and not into the national forest account, and as a consequence there were insufficient funds to support a viable, sustainable domestic industry; "since 1994 all income, including subsidies from the national general account, has been used to service long term debt, the deficiency has been covered by new debt" ${ }^{25}$ This clearly shows how the government, in spite of laws and initiatives, failed to implement a sound policy to protect the domestic industry.

\section{The trio behind the forestry policy and timber trading}

The Japanese forestry policy has been primarily developed, shaped, and influenced by the three bodies which together form an 'Iron Triangle'. In this instance it is the Forestry Agency of the Ministry of Agriculture, Forestry and Fisheries (MAFF), the Sōgō Shōsha (Japanese general trading companies), and the Ministry of International Trade and Industry, later renamed as the Ministry of Economy, Trade and Industry. Although the three bodies had different roles in collectively shaping the forestry policy, they each ensured that their best interests were safeguarded. The focus of the policy had gradually shifted away from the central aim of fostering domestic timber production, to providing a greater emphasis on

\footnotetext{
${ }^{23}$ Ito, "Logging and log distribution", p. 167.

${ }^{24}$ K. Naito, "Kyōsei keizai he no michi (2), Yutaka na mori ga chiiki wo hagukumu (Path to coexistence with economy No.2, Rich forests enhance the community)" 21 Seiki bijinesu juku ( $21^{\text {st }}$ Century Business cram school), 23 April 2004, Nippon Hōsō Kyōkai (NHK), http://www.nhk.or.jp/business 21, (accessed 26 February2005).

${ }^{25}$ Matsushita, "National forest management", p. 99.
} 
creating an environmental consciousness towards forestry resources. Protecting Japan's forests had now become the priority.

Figure 3: The triangle of players in the Japan's forestry policy

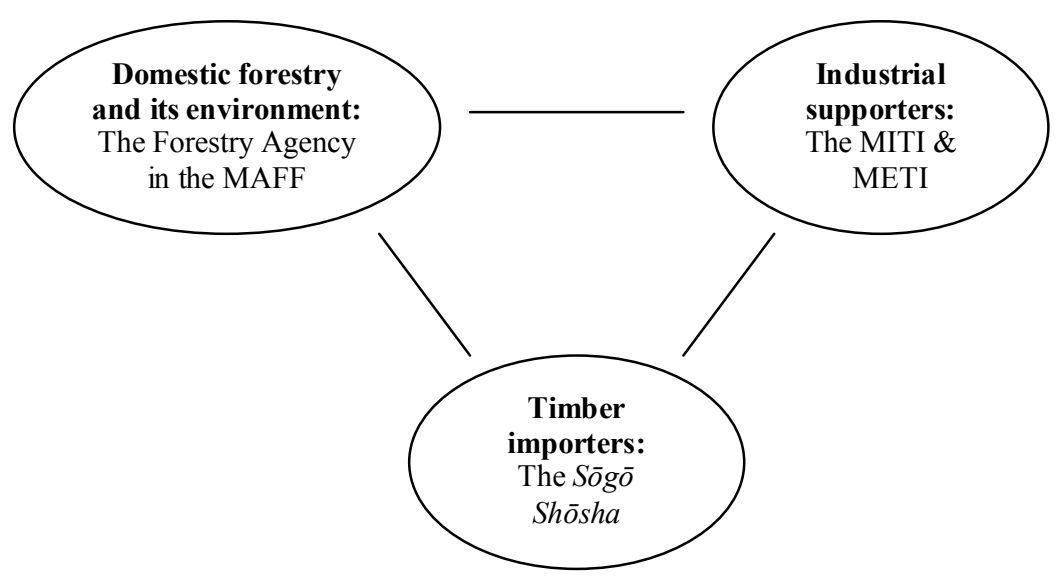

Source: Compiled by the author

The individual roles of the three bodies were as follows. The Forestry Agency sought to promote the wellbeing of the domestic forestry industry and to ensure a 'green environment' within the forests. The $S \overline{o g} \bar{o}$ Shōsha aimed to enhance profits by increasing timber importing activities. The role of the MITI and METI in policy formation did not appear to be very significant; their main role appeared to be to support and protect the trading environment of the Sōgō Shōsha.

\subsection{The Forestry Agency}

Following the democratization of Japan, the Forestry Agency was established in 1947 as a branch within the MAFF. Previously in the Meiji period, Japanese forests and the forestry industry were managed by the Japanese National Forest Management under the aegis of the 
Imperial Household. ${ }^{26}$ The Agency administers and shapes Japan's forestry and timber industry through the Rinsei-bu (林政部: department of forestry policy). There are three major roles that the Agency plays today; it promotes the domestic timber industry, it manages forests for disaster prevention and for recreational purposes, and it initiates measures to mitigate global warming. The Japanese government's national forest budget for fiscal year 2008 was $¥ 462$ billion, $¥ 335$ billion of which went to public related projects in Japan’s forestry. ${ }^{27}$ The $¥ 335$ billion, about 70 percent of the total budget, was spent on landslide and natural disasters in the forestry area, and also for promoting a strong awareness of the forestry environment.

When the Agency was established in 1947 its brief centered on domestic timber production; however, from the late 1980s it has promoted global environmental initiatives. Some recent tasks include initiatives to combat global warming, and portraying Japan's image as a country that practices 'green forestry'. Three roles that the Forestry Agency plays in shaping Japan's forestry policy will be examined.

First, since the implementation of the government 'timber import liberalization policy', the Agency has endeavored to promote the domestic industry. Due to the increase in imported timber, the Agency enacted the 1964 BFL in order to stress the importance of domestic forestry, and the domestic timber industry. However, the law was deficient in that it focused on projected yields from the plantations; it did not take into consideration market conditions. ${ }^{28}$ The Agency identified two problems involving forest workers: their productivity and their welfare. An assessment of Japanese forestry productivity shows that in the early 1980s it was 2.0 cubic meters per worker day, whereas in Sweden it was 7.1, and in Canada 13.2. ${ }^{29}$ Japan was clearly at a disadvantage as its national forests were generally located in mountainous regions where economies of scale were not able to be realized. However, in spite of the

\footnotetext{
${ }^{26}$ Matsushita, "National forest management", p. 85.

${ }^{27}$ Shinrin kyūshū mokuhyō tassē ni muketa heisei 20nen do no taisaku ni tsuite (Measures in 2008 aimed at countering carbon dioxide emissions through forestry absorbtion), the Forestry Agency, 2007, http://www.rinya.maff.go.jp/policy2/h20yosan/h20jyuuten.pdf, (accessed 28 July 2008).

${ }^{28}$ Matsushita, "National forest management", p. 105.

${ }^{29}$ K. Akao, "Private Forestry", in Iwai (ed.), Forestry and the forest industry in Japan, USB Press, Vancouver, 2002, p. 27.
} 
government identifying its responsibilities towards its foresters, timber imports continued to overwhelm the industry: it needed more than just promotion; it needed protection.

Second, the Agency was now placing a greater emphasis on using the forests for recreational purposes. This change had been prompted by the expectations of the Japanese public whose opinion can influence the direction of a government policy. According to a Japanese public opinion poll, even though its citizens believed that Japan's forests should provide an economic activity through the supply of timber, they also want to see the forests used more for recreational purposes. ${ }^{30}$ This illustrates an egocentric philosophy on their part; the Japanese want to preserve the quality of their own forests but fail to take into account the fact that other nations' forests would be denuded in order to sustain their affluent lifestyle. The poll also showed that although the public believed that Japan's forests should be improved to combat natural disasters, 67 percent of them expected the central and local governments to participate actively in global environmental initiatives. ${ }^{31}$ It can be assumed that with the high economic growth that has resulted from an increased urban lifestyle, many Japanese had lost the close relationship and interaction with their forests. The government had emphasized and encouraged public participation in the country's forestry development. Although the Forestry Agency stressed the importance of revitalizing the domestic timber industry; for instance by using 'green employment' the forestry policy was shifting from the primary aim of timber production to a more eco friendly use of the forests. Privately owned forests might survive through leases and subsidies, but it was unlikely that harvesting them would be economically viable. $^{32}$

Finally, the forestry policy promised to contribute towards projects that would help mitigate global warming and that the contribution was to be a part of MAFF domestic initiatives. In March 2002 the Forestry Agency adopted a formative approach named, 'A 10 year strategy to prevent global warming through forest absorption'. There were five principles involved in the strategy; they were improving the health of the forests, a management plan to give adequate

\footnotetext{
${ }^{30}$ Shinrin to seikatsu ni kansuru yoron chōsa (Public opinion poll regarding forests and lifestyle), the Forestry Agency, December 2003, available at: http://www.rinya.maff.go.jp/puresu/h16-3gatsu/0301survey.htm, (accessed 17 October 2007).

${ }^{31}$ Ibid.

${ }^{32}$ Akao, "Private Forestry", p. 40.
} 
protection to the forests, public participation in the projects, promotion of biomass techniques, and the strengthening of the $\mathrm{CO}_{2}$ intake recording system. ${ }^{33}$ The Agency showed two faces, the first that promoted a 'green consciousness' and the second that promoted logging. The vision of 'Green Forestry' might seem to be an environmentally sound idea, but the vision had a narrow focus on global warming; it did not take into account the many non-humans that inhabit the forests. Traditional Japanese religious and cultural principles emphasized reciprocal care, respect, and compassion towards animals as they often represented different Gods that protected humans and their agriculture, and in return, people will return on (恩) to them (mentioned in Chapter one).

If the Forestry policy does not also take into account the intrinsic value of the environment, then the soundness of the policy based on Japanese environmental ethics is questionable. As mentioned, 70 percent of Japans land mass is covered by forests and they host an abundant, diverse wildlife. The Agency saw forests primarily as a timber resource for human use and ignored the non-human inhabitants of the forests that were also dependent on that resource. The strong focus by the Agency on timber production is shown by its concern that deer and bears damaged 8,000 ha of forest annually. ${ }^{34}$ The contradiction in the Agency's 'Green Forestry' approach is that it ignored the fact that the non-human element is an important component of the forests.

Although the Forestry Agency's policy showed a move towards greater forest preservation, the Agency itself projected a somewhat mixed image. Whilst the Agency recognized the importance of sustainable domestic forestry, the Ministry of Environment saw it differently. According to the Ministry, forests needed protection as they are not only important for the many types of fauna that live there, but are valuable for the production of timber, a necessity for human beings. ${ }^{35}$

\footnotetext{
${ }^{33}$ Chikyū ondanka bōshi shinrin kyūshū gen 10 ka nen taisaku (A 10 year strategy to prevent global warming through forest absorption)", the Forestry Agency, December 2002, available at: http://www.rinya.maff.go.jp/seisaku/sesakusyoukai/ondanka/10kanen-3.html (accessed 19 October 2007). ${ }^{34}$ Yaseichōjyū ni yoru higai no jittai to taisaku (Damage from wild animals and the counter measurements), the Forestry Agency, available at : http://www.rinya.maff.go.jp/seisaku/sesakusyoukai/mamoru/3.htm, (accessed 19 October 2007).

${ }^{35}$ Naze shinrin wo mamoranakereba naranainoka (Why do we need to protect forests?), the Ministry of Environment, 2004, http://www.env.go.jp/earth/shinrin/pamph/p05.pdf (accessed 19 October 2007).
} 
These three policy approaches demonstrate that the Forestry Agency has been influenced by the wave of global environmental awareness and has moved away from the central focus of timber production, to a broader perspective of forest use.

\subsection{Sōgō Shōsha}

Sōgō Shōsha are Japanese general trading companies and there are three features that illustrate their role in Japan's forestry policy. The first is that they are involved in most fields of commerce that range through distribution, finance, transportation, and information technology. Mikio Sugino identified four characteristics of Sōgō Shōsha; one, their trading practices extend into industrial areas; two, the depth of their activities that extends to third nation trade; three, their involvement in multinational activities such as natural resource development and investment; and four, their sheer size, which he described as 'monopolized industrial capital'. ${ }^{36}$ The Sōgō Shōsha's business activities know no boundaries; they operate as borderless corporations. Their huge number, and there are more than 8000 of them, is a significant force in the Japanese economy; the dominant ones are Mitsubishi, Mitsui, Marubeni, Sumitomo, and Itochu. Whilst the Forestry Agency takes responsibility for the administration of domestic timber issues, the Sōgo Shōsha are timber importers and traders and have a dominant position in global timber trading. The Sōgō Shōsha's keiretsu (explained below) co-operate closely with the local ruling elite in the supplying of overseas countries and use this to great effect when acquiring natural resources. Nobuo Kawabe pointed out that the Japanese trading companies engage not only in direct trading activities, but also in thirdcountry trading and activities that includes the introduction of technologies, the development of natural resources, and manufacturing activities. ${ }^{37}$ Japan's trading companies might not directly influence their government's forestry policy, but their practices certainly impact on the Japanese domestic forestry industry, and on the socio-environmental wellbeing of the

\footnotetext{
${ }^{36}$ M. Sugino, Sōgō Shosha no shijō shihai (Market monopoly of Sogo Shosha), Ōtsuki Shoten, Tokyo, 1990, p. 2 -3 .

${ }^{37}$ N. Kawabe, "Overseas activities and their organization” in S. Yonekawa (ed.), General trading companies: a comparative and historical study, United Nations University Press, Tokyo 1990, p. 170.
} 
trading nations. Peter Dauvergne argues that the Sōgō Shōsha thrive on resources extracted from unsustainable sources, and then sell them at prices that have ignored environmental costs. $^{38}$

The second feature of the Sōgō Shōsha's is their business practices; they are Japan's main driving force in the global timber market and skillfully dominate the timber trade. These practices can be traced back to their origins in the Japanese zaibatsu (industrial as well as business finance conglomerates) that exerted control over Japan's economy during the Meiji period up until the end of the WWII. Even though General MacArthur dissolved the zaibatsu structure during the occupation, after its end in 1952 the former conglomerates reemerged as newly developed companies. They survived and thrived and maintained traditional Japanese business practices; an important aspect of these activities is the use of the Japanese keiretsu system. Keiretsu are the key links in the Japanese trading chain that connect the Japanese companies to the overseas markets. Dennis Encarnation explained that keiretsu is a vertical network of Japanese corporations that links the Japanese buyers and their suppliers. ${ }^{39}$ An example is Mitsubishi Corporation, the largest of the Sōgō Shōsha. It has control over a network of 118 companies (shown as business investments on their website) within Japan and overseas. Its network is established in 63 countries (20 in Europe, 20 in the Asia Pacific, 13 in Africa and 10 in the Middle East). ${ }^{40}$ The success of the keiretsu within the Sōgo Shōsha is that they have grown from a cultural tradition. They are founded on Confucian thought that stresses the principle of family loyalty and an interdependence through organizational networks; this philosophy has been applied and has proved their strength. It can be seen that Japanese corporate philosophy is a combination of Confucianism, Buddhism, and the Japanese hierarchical system.

\footnotetext{
${ }^{38}$ P. Dauvergne, Shadows in the forests, Japan and the politics of timber in Southeast Asia, Massachusetts Institute of technology, Cambridge, 1997, p. 6.

${ }^{39}$ D. Encarnation, "Introduction, Japanese multinationals in Asia" in Dennis Encarnation, Japanese multinationals in Asia, regional operations in comparative perspective, Oxford University Press, New York, 1999, p. 9.

${ }^{40}$ Global Network, Mitsubishi Corporation, Japan, available at:

http://www.mitsubishicorp.com/en/network/index.html, (accessed 25 October 2007).
} 
The Sōgo Shōsha play a significant role in shaping the Japanese economy. In the 2005 financial year the total sales from the seven major corporations, comprising over 4,000 companies, valued at some US\$720 billion. ${ }^{41}$ These figures illustrate that they are not just ordinary trading companies, but are companies that control and direct global commodities and resources to the benefit of the Japanese owners.

The Sōgo Shōsha are not only powerful organizations, but are also monopolistic; they use keiretsu to dominate and manipulate the market to achieve their aims. This illustrates a typical style of Japanese business conduct. The sheer size of the Sōgō Shōsha is extraordinary and they have no equivalent in other countries. Mitsubishi is a good example of their dimension; its total assets (consolidated financial results) at the end of the 2007 Japanese financial year was US\$115 billion, their trading transactions totaled some US\$205 billion, and their net income was US\$4.1 billion. ${ }^{42}$ Furthermore, Mitsubishi’s operations show that it is more than a straight forward trading company through its use of the keiretsu system; it has 55,867 employees, and 1,040 keiretsu of which 618 operate beyond Japan's borders. ${ }^{43}$ Table 1 lists the top six Sōgō Shōsha.

\footnotetext{
${ }^{41}$ Shōsha no katsudō (Shōsha's activity), Nihon bōeki kai (the Japan Foreign Trade Council, Inc.), http://www.jftc.or.jp/shosha/activity/p02.html, (accessed 22 October 2007).

${ }^{42}$ Shōsha gyōseki hyō (Shōsha, business achievement) as at March 2007 by Nihon bōeki kai (the Japan Foreign Trade Council, Inc.), 16 May 2008, http://www.jftc.or.jp/shosha/balancesheet/200703Shoshas-jpn.pdf, (accessed 24 October 2008).

${ }^{43}$ Kaisha jyōhō (Company information), Mitsubishi Shōji , 2007, http://www.mitsubishicorp.com/jp/about/index.html, (accessed 23 October 2007).
} 
Table1: Financial results (consolidated) as at 31 March 2007 of the top six Sōgō Shōsha and their keiretsu.

\begin{tabular}{|l|r|r|r|r|}
\hline & \multicolumn{1}{|c|}{ Sales profit } & Net Income & Employees & Keiret-su \\
\hline Mitsubishi Corporation & $¥ 20$ trillion & $\$ 4.1$ billion & 55,867 & 1,040 \\
\hline Mitsui \& Co., Ltd & $¥ 15$ trillion & $\$ 3.1$ billion & 41,761 & 491 \\
\hline Sumitomo Corporation & $¥ 10$ trillion & $\$ 2.1$ billion & 61,490 & 898 \\
\hline Marubeni Corporation & $¥ 9$ trillion & $\$ 1.2$ billion & 28,442 & 561 \\
\hline Itochu Corporation & $¥ 11$ trillion & $\$ 1.8$ billion & 45,690 & 651 \\
\hline $\begin{array}{l}\text { Toyota Tsusho } \\
\text { Corporation }\end{array}$ & $¥ 6$ trillion & $\$ 0.8$ billion & 22,945 & 361 \\
\hline
\end{tabular}

Source: Nihon bōeki kai (Japan Foreign Trade Council, Inc), ${ }^{44}$ compiled by the author

The final feature of the Sōgo Shōsha is their domination of Japan's timber trade, and the importance of their keiretsu chain to expand further business opportunities. The chain has a network of links with timber suppliers and contractors in the timber producing regions that gives further strength to the $S \overline{o g} \bar{o}$ Shōsha corporate power. As each trading company has hundreds of affiliated companies in all regions of the world, and as these are closely tied to regional contractors, this arrangement has been of tremendous benefit to Japan's trading interests. Dauvergne pointed out that the $S \overline{o g} \bar{o}$ Shōsha provide manufactures with a steady supply of resources, credit, low-interest loans, and reliable established links to buyers. ${ }^{45}$ The Sōgō Shōsha co-ordinate well with its keiretsu chains and this enables them to exert power and control over the world markets; the $S \overline{o g} \bar{o}$ Shōsha can be likened to a spider in a cobweb; they play a central role with connections over a wide area. For example, Peter Dicken and Yoshihiro Miyamachi stated that the electronics manufacturer Toshiba is a parent company that controls substantial numbers of companies including parts suppliers in vertically integrated Toshiba groups which are in turn horizontally integrated with other groups such as Mitsui. $^{46}$

\footnotetext{
${ }^{44}$ Shōsha gyōseki hyō (Shōsha, business achievement) as at March 2007 by Nihon bōeki kai (the Japan Foreign Trade Council, Inc.), 16 May 2008, http://www.jftc.or.jp/shosha/balancesheet/200703Shoshas-jpn.pdf, (accessed 24 October 2008).

${ }^{45}$ Dauvergne, Shadows in the forests, Japan and the politics of timber in Southeast Asia, p. 33.

${ }^{46}$ P. Dicken and Y. Miyamachi, “From noodles to satellites': the changing geography of the Japanese sogo shosha", Transactions the Institute of British Geographers, New Series, vol. 23, no. 1, 1998. p. 56.
} 
Dauvergne pointed out that the $S \bar{o} g \bar{o}$ Shōsha do not try to maximize profits on their imports, but prefer instead to maintain a high trading activity through small commissions. ${ }^{47}$ With the need for a secure and ready supply of timber for their Japanese customers, the Sōgo Shōsha skillfully use their keiretsu to control timber resources from the supplying regions. An example is the Sōjitsu Building Material Corporation, a keiretsu of Sōjitsu Corporation (a Sōgō Shōsha) whose core timber business has expanded overseas through a network of joint ventures. One such venture was with Tachikawa Forest Products (NZ) Ltd. in 1989 which led to the formation of the largest timber factory in New Zealand; this allowed Sōjitsu to expand its timber exports to China, Southeast Asia, and the Middle East. ${ }^{48}$ Furthermore, in the following year it established the PT Mitra Mutiara Woodtech timber processing factory in Surabaya, Indonesia, ${ }^{49}$ to ensure a constant supply of timber products from that region. The Shogo Shōsha practice of using their keiretsu to keep the price of timber artificially low deprives the exporting countries of a fair royalty.

The $S \overline{o g} \bar{o}$ Shōsha claim to promote sustainable forestry policies by initiating afforestation projects abroad but the reality is that the projects are tied to the Sōgo Shōsha and this guarantees them a constant supply of timber. Far from being altruistic global environmental initiatives, the projects are in reality further business opportunities where the true benefits to the host countries are often inadequate.

Since the 1990s, the Japanese government and Japanese trading companies have undertaken global environmental initiatives to cut down on $\mathrm{CO}_{2}$ gas emissions, Japan wants to be seen as a country that is committed to combating the global environmental crisis. While 70 percent of Japan's land is covered with forests, which is about 25 million hectares, Mitsui Bussan owns about 44,000 hectares which produces a public value of $¥ 120$ billion and absorbs 160,000 tons of carbon dioxide annually. ${ }^{50}$ However, there is a question of a genuine 'green approach' in

\footnotetext{
${ }^{47}$ Dicken and Miyamachi, "From noodles to satellites': the changing geography of the Japanese sogo shosha”, p. 33.

${ }^{48}$ Jigyō annai (Our business), Sōjitsu kenzai kabushiki kaisha (Sojitz Building Materials Corporation), 2007, http://www.sojitz-bm.com/business/index.html, (accessed 26 October 2007).

${ }^{49}$ Ibid.

${ }^{50}$ Mitsui Bussan no mori: Shinrin no kōeki teki kinō (Mitsui Corporation's forest: The forests function for public benefit), Mitsui Bussan Kabushiki Kaisha, 2008, http://www.mitsui.co.jp/csr/forest/function/index.html, (accessed 24 September 2009).
} 
the Sōgō Shōsha's domestic afforestation projects. Limited land availability and high logging costs generally persuade them to locate their forestry operations overseas where they can find much cheaper and more suitable broadacre land that has a greater potential for lower production costs.

2.3. The Ministry of International Trade and Industry (to 2000), and the Ministry of Economy, Trade and Industry (from 2001)

The third player in the timber industry is the Ministry of International Trade and Industry (MITI), and its successor the Ministry of Economy, Trade and Industry (METI) since 2001. When the Japanese government restructured its ministries in 2001, the MITI was renamed the METI. The name change followed role changes as well. Gregory Corning stated that there was a functional change to the integration of macroeconomic and microeconomic policy in the new Economic and Industrial Policy Bureau. ${ }^{51}$ Both ministries supported the timber industry in line with the central government's aims and in the country's national interests. The METI acts as a hidden though significant player in the formulation of Japan's industrial policy: it acts as a supporter for the Sōgō Shōsha's timber import activities.

Gandolfo Dominici argues that the METI is at the center of the Japanese network system through which Japanese corporations develop industrial initiatives. ${ }^{52}$ The METI completes the triad in Japan's forestry and timber policy activities; the Forestry Agency administrates the domestic forestry matters and timber industry, the $S \overline{o g} \bar{o}$ Shōsha imports the timber, and the METI frames Japan's trade policy. As discussed in Chapter 3, the Japanese government emphasizes that global environmental concerns are an important element in Japanese policies. Whilst Japan may commit itself to global environmental initiatives, policies that are related to the nation's economic welfare emphasize that securing resources is vital and timber is an important part of them. The METI, which is responsible for Japan's economy, is central to Japan's timber trade and actively supports the Japanese trading companies and accommodates

\footnotetext{
${ }^{51}$ G. Corning, Japan and the politics of techno-globalism, M.E.Sharpe, Inc., New York, 2004, p. 196.

${ }^{52}$ G. Dominici, From business system to supply chain and production in Japan, 2003, http://www.unipa.it/gandolfodominici/Business-sys-SCM2003.pdf, p. 16 (accessed 29 October 2007).
} 
their requirements. Two examples illustrate how the METI works closely with the Shogo Shōsha.

The first relates to the Japanese government's tariff policy on lumber and timber products. In 1964 the Japanese government abolished the tariff on logs and gradually reduced tariffs on plywood and other timber products from 20 percent in 1964 to 6 percent in $1999 .^{53}$ This encouraged the Shogo Shōsha to import more lumber and timber products into Japan; the consequence of this was that the domestic timber industry was put into further difficulty. There are two explanations to show why the government acted in this way. The first is that the domestic forestry industry has relatively little political power and receives little protection, unlike the domestic rice industry. The long ruling Liberal Democratic Party (LDP) protects the interests of Japan's rice farmers who have a strong political influence and, as a result, imported rice has continued to attract a high tariff. At the 2008 meeting of the World Trade Organization aimed at reducing tariffs, the MAFF struggled to protect the 778 percent tariff on milled rice; Japanese farmers have said that tariff reduction has "become a matter of life and death". 54 The Japanese farming sector is well protected by the LDP due to its voting power, but no such consideration has been shown to domestic forestry; it seems to be the least supported of the agricultural industries. The second explanation is that the MITI and METI who were responsible for trade, emphasized economic growth and encouraged the trading companies to import timber by reducing tariffs. This was largely to do with promoting the Japanese economy, but there was also an element of close collaboration between the trio of timber industry players.

A second example shows how the METI has been working towards improving access to overseas timber supplies for the Japanese timber trading companies. Mikio Sugino drew attention to three aspects that demonstrate how the $S \bar{o} g \bar{o}$ Shōsha have greatly changed the Japanese timber market through their timber imports: firstly, the role of the keiretsu; secondly, the $\operatorname{Sog} \bar{o}$ Shōsha sponsored specially designed ships for timber transportation; ${ }^{.5}$ and thirdly,

\footnotetext{
${ }^{53}$ FoE Japan, Shinrin puroguramu (Forestry program), available at: http://www.foejapan.org/forest/trade/factsheet01.html, (accessed 29 October 2007).

${ }^{54}$ WTO proposal plagues farmers, Japan Times Online, 29 July 2008, http://search.japantimes.co.jp/cgibin/nb20080729a3.html, (accessed 25 March 2009).

${ }^{55}$ M. Sugino, Sōgō Shōsha no shijō shihai (Sōgō Shōsha's market control), Ōtsuki Shoten, Tokyo, 1990, p. 274.
} 
the central and local governments invested in large public infrastructure projects such as ports and timber storage facilities ${ }^{56}$ demonstrating the readiness of the Ministry to facilitate trade through Sōgō Shōsha. The METI has as well been working towards improving the access by Japanese trading companies into the Malaysian market. There are at least two reasons for this: firstly, Malaysian import comprises about 60 percent of the total imports of plywood into Japan, and secondly, according to Nihon Yunyū Kyōkai (Japan Import Association), Malaysian plywood is acknowledged as 'legal' timber. ${ }^{57}$ In May 2005 the Japanese government led by Prime Minister Junichirō Koizumi made an agreement with the Malaysian government for an 'economic partnership'; with that agreement the Japanese government took the radical step of allowing Malaysian agriculture, forestry, and fishery products to be imported into Japan tariff free by $2015 .^{58}$ Furthermore, the Japanese government immediately removed tariffs on forestry products with the exception of plywood. ${ }^{59}$ Without question the economic partnership has benefited both nations from ODA to assisting trade activities; but the tariff free strategy will however add to the serious disadvantage of the domestic Japanese timber producers. The tariff strategy is of little advantage to the domestic forestry industry although it creates a more advantageous environment for the timber importers, which are of course the Sōgo Shōsha.

The two countries started their diplomatic relationship in 1947 and economics were an important part of it. Japan has achieved a more rapid economic development, though the relationship was meant to be more along the lines of a reciprocal arrangement. According to the Japanese MOFA, Japan's economic cooperation (cumulative total in fiscal year 2005) with Malaysia comprised \$9,693 million in loans, \$122 million in grants, and \$105 billion in technical co-operation. ${ }^{60}$ Technical cooperation is the most favoured approach in Japanese overseas economic collaborations as technology, especially that related to the environment, is a core element in the government's policy approach (see chapter 3). It is confident of the

\footnotetext{
${ }^{56}$ Sugino, Sōgō Shōsha no shijō shihai (Sōgō Shōsha's market control), p. 274.

${ }^{57}$ Marēshia, sarawaku san mokuzai, hontō ni gōhō desuka (Is the timber from Sarawaku in Malaysia legitimite?). Fairwood, 2008, http://www.fairwood.jp/printdoc/prdc mel26 02.shtml, (accessed 25 March 2009).

${ }^{58}$ Nichi Malaysia keizai renkei kyōtei (Japan-Malaysia economic partnership Agreement) by the Ministry of Economy, Trade and Industry, 25 May 2005, available at: http://www.meti.go.jp/policy/trade policy/epa/data/malaysia JointPressStatement j.pdf, (accessed 29 October 2007).

${ }^{59}$ Ibid.

${ }^{60}$ Japan-Malaysia Relations, by the Ministry of Foreign Affairs of Japan, November 2007, http://www.mofa.go.jp/region/asia-paci/malaysia/index.html, (accessed 2 January 2007).
} 
ability of technology to solve environmental problems. In forestry issues, the "economic partnership' with Malaysia has made it easier for Japan's Sōgō Shōsha to trade in timber and timber products; the tariff free agreement points up one characteristic of Japan's economic development strategy.

The involvement of the METI suggests that there are strong 'economic interests' in forestry issues. Even though overseas forests are being denuded with the resultant social and economic damage, Japan's corporate interests maintain a 'business as usual' attitude. The primary requirement is a ready and sustainable supply of timber for their mills; maintaining a viable and healthy domestic forestry industry and ensuring a sustainable industry for the countries' from which it imports, is of lesser importance.

\section{Japan's timber imports}

Japan's timber requirements in 2006 amounted to approximately 90 million metres of which around 80 percent was imported. ${ }^{61}$ Figure 1 shows that Japan's self-sufficiency rate of about 20 percent in 2005 had changed little over the preceding 5 years. From the 1970s the massive growth of the Japanese timber industry was sustained by imports; the activities of the global timber traders created major problems in world forests and have become a matter for serious concern. The requirements from Japanese and global traders encourage developing nations to use clear felling techniques to meet this demand, with the result that forest ecosystems are disturbed and degraded. The upshot is a loss of biodiversity and an excessive run off of ground water; the subsequent river pollution and spoilt environment creates a situation where the livelihoods of the indigenous societies can no longer be sustained.

\footnotetext{
${ }^{61} 2006$ Forestry White Paper, Forestry Agency, http://www.maff.go.jp/j/wpaper/w rinya/h19/pdf/data4-1.pdf, (accessed 21 July 2008).
} 
Of 193 countries in the world today, Japan imports timber from 130 of them. ${ }^{62}$ The pattern of Japan's timber imports has been one of constant expansion and there is every indication that it will continue; Japan has as a consequence of its heavy involvement in the international timber trade a moral responsibility to the global environment. The Forestry Agency revealed that in 2005 Japan was the world's third largest user of industrial logs, and the second largest user of sawmill logs. ${ }^{63}$

The United Nations Food and Agriculture Organization reported in the same year that Japan was the world's second largest consumer of sawn timber, the third largest user of paper and paperboard, and the fourth largest of pulp wood for paper. ${ }^{64}$

Figure 4: Volume of timber imported into Japan

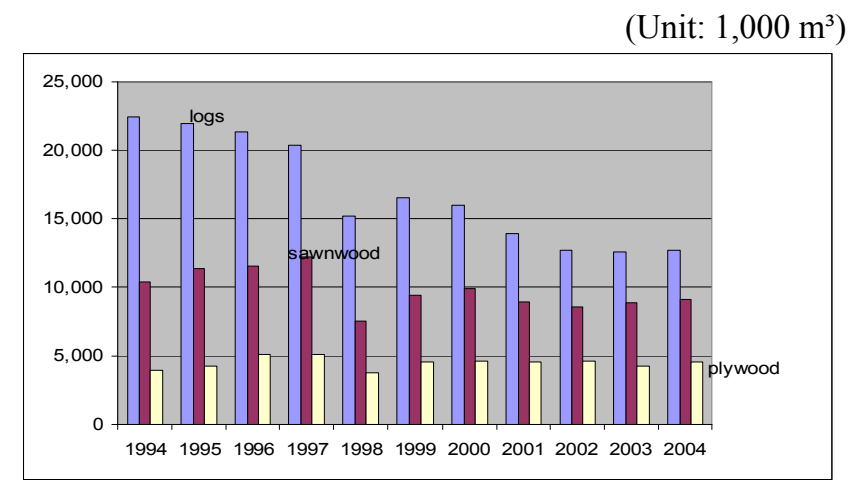

Source: The Forestry Agency, http://www.maff.go.jp/hakusho/rin/h16/html/r1050138.htm, (accessed 24 September 2007), compiled by the author

Japanese timber imports can be categorized into three general types; logs, sawn wood, and plywood. Since 1994 Japan has significantly reduced the quantity of imported logs from around 80 million metres in 1994, to around 70 million in 2003 (see Figure 4). There are two probable reasons for this. The first is the ending of the Japanese bubble economy in the early

\footnotetext{
${ }^{62}$ M. Yabe, Mori no chikara, Nihon rettō wa shinrin hakubutsukan da (The power of the forests, The Japanese archipelago is a forest museum), Kōdan-sha, Tokyo, 2002, p. 183.

${ }^{63} 2005$ Forestry White Paper, Forestry Agency, http://www.maff.go.jp/hakusho/rin/h18/html/data02.pdf, (accessed 27 September 2007).

${ }^{64}$ Food and Agriculture Organization of the United Nations, the date is available at: http://www.fao.org/forestry/site/28679/en, (accessed 11 October 2007).
} 
1990s that led to a slowing of the economy and a reduction in the demand for timber. The second was a growing consciousness of environmental protection in the timber exporting countries, resulting in restrictions dependent on the form in which the timber was exported, i.e., round logs, sawn logs, and sawn timber. Figure 5 shows that imported timber was about three times that of domestic logged timber; the imports are essential not only to meet Japan's domestic needs but also to feed the flow-through of the value added timber import/export industry, a high percentage of which goes to China. Although the total amount of timber imported into Japan has decreased, that reduction is not common with all the countries from which it imports.

Figure 5: Comparison of imported and domestic timber (log conversion)

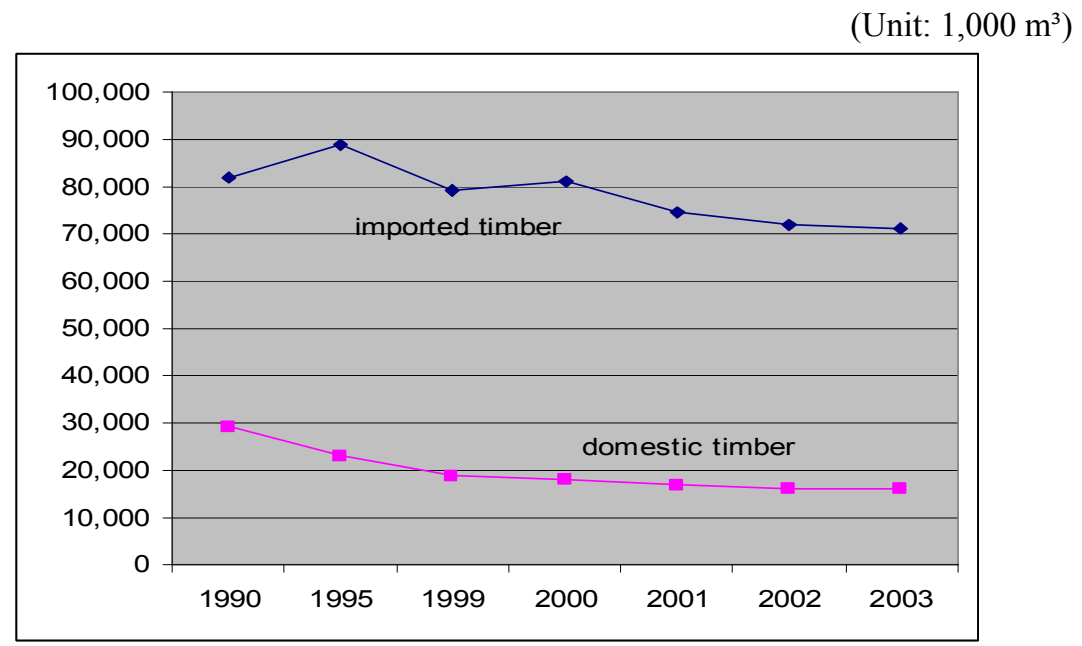

Source: Forestry Agency, http://www.maff.go.jp/hakusho/rin/h16/html/r1050136.htm, compiled by the author

Since 1990 countries such as the United States and Malaysia have significantly reduced the amount of timber which they export to Japan, whereas Russia and Australia have more than doubled their exports to the country. During the 1990s, Japan changed timber suppliers (see Table 2): timber imports from Malaysia declined by 50 percent whereas imports from Europe and China increased dramatically although steadily. There are several reasons for the European increase. According to Iwai and Yukutake, one factor was the change in method of 
house construction in Japan. European kiln-dried and laminated timber was well suited to the new method and was earthquake resistant; this was a particularly important factor after the Han-Shin earthquake in $1995 .^{65}$

Table 2: Timber exporting countries to Japan (1990-2003)

\section{NOTE:}

This table is included on page 228

of the print copy of the thesis held in the University of Adelaide Library.

Source: Forestry Agency, available at; http:/www.maff.go.jp/hakusho/rin/h16/html/r1050136.htm, (accessed 28 September 2007)

In 1993 the pattern of Japan's timber imports went through two changes. The first occurred when the European Union (EU) was established and the Japanese government strengthened its economic ties with it. The emergence of the EU as a powerful trading bloc made it one with which Japanese business wanted to engage. During the 1990s, Finland, Sweden and Austria were the main EU exporters to Japan and accounted for 90 percent of the total. ${ }^{66}$

The second change occurred when Malaysia imposed a ban on log exports. This forced Japan to look to other countries such as Papua New Guinea for supplies. In spite of Japan's

\footnotetext{
${ }^{65}$ Iwai and Yukutake, “Japan's wood trade”, p. 255.

${ }^{66} 2004$ Forestry White Paper Forestry Agency, available at

http://www.maff.go.jp/hakusho/rin/h16/html/r1050136.htm, (accessed 28 September 2007)
} 
economic stagnation during the 1990s, the high value of the Japanese currency made importing timber economically attractive. One consequence of the strong Yen was that it favored imported timber to the detriment of the domestic industry and demand for the domestic product fell from 29.3 million metres in 1990, to 18.7 million metres by $1999 .^{67}$

Whilst the total demand since 2000 for imported timber and timber products, particularly plywood and sawn wood, has remained stable, the timber suppliers to Japan have changed. The Forestry Agency reported that log imports from Russia increased from 24.7 percent in 1995 to 46.9 percent in 2006, sawmill timber from Europe from increased from 7.3 percent to 35.3 percent, and plywood from China increased from 0 percent to 15.6 percent. ${ }^{68}$ Timber suppliers to Japan have shifted from traditional suppliers such as Indonesia, Malaysia and others to new suppliers such as Europe and China.

Japan's dependency on imported commodities has grown tremendously since the end of World War II and amongst them timber is a major one. An overlooked feature of Japan's timber trade is the amount of raw timber that is imported, value added through processing, and then exported. This is happening on a large scale with China where that country is both the exporter of the logs, and the importer of those logs in the form of timber products. The Japanese Forestry White Paper of 2006 reported Japan had exported around \$100 million worth of timber products in that year: of that, the largest amount was destined for China whose imports from Japan grew from \$11 million in 2001 to \$36 million in 2006. ${ }^{69}$ Japanese industry, especially the construction and manufacturing sections, are now totally reliant on imported timber for their survival. Value adding to imported timber for export has now become a necessary activity to ensure the profitability of the general timber industry.

\footnotetext{
${ }^{67} 2004$ Forestry White Paper Forestry Agency.

${ }^{68}$ Rinsanbutsu jukyū to mokuzai sangyō (Supply of forestry products and timber industry), 2006, the Forestry Agency, http://www.maff.go.jp/j/wpaper/w rinya/h19/pdf/data4-1.pdf, (accessed 24 March).

${ }^{69} 2006$ Forestry White Paper, the Forestry Agency, http://www.maff.go.jp/hakusho/rin/h18/htm/data02.pdf, (accessed 30 September 2007).
} 


\section{Timber usage}

Eighty five percent of Japan's timber requirements are used by two major industries, the paper and paperboard manufacturers, and the construction industry; the first accounts for 42 percent, and the second for 43 percent (Figure 5).

\section{Figure 5: Timber usage in Japan by percentage}

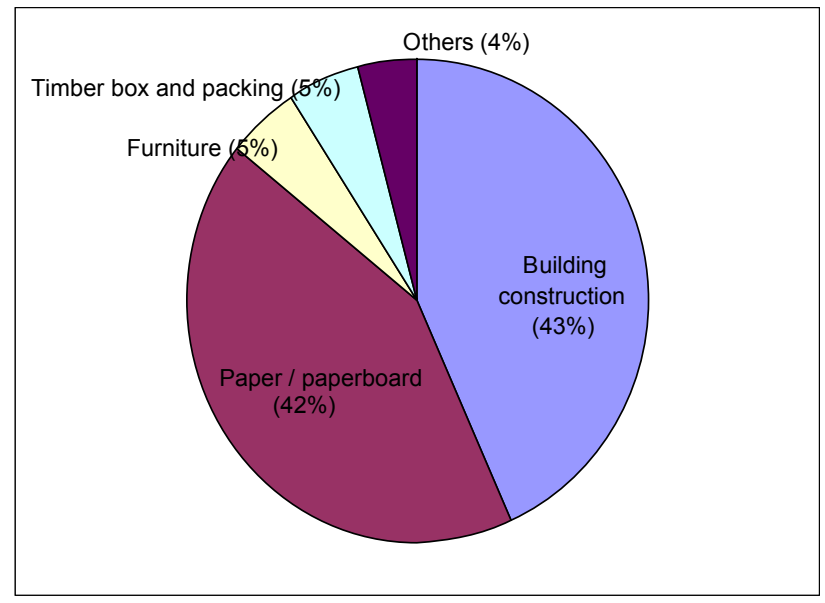

Source: Mokuzai no yōto (timber usage), http://www.shinrin-ringyou.com/mokuzai/mokuzai youto.php, (accessed 26 September 2007), compiled by the author.

This section examines the manner in which these industries use the resource.

\subsection{Building construction}

Due to the tremendous number of Japanese homes and buildings destroyed in WWII, there was a shortage of 4.2 million houses in the early postwar period, $;^{70}$ building reconstruction then became an important part of the nation's economy. As Japan was achieving a record high in economic growth during the 1960 s, so too did the building construction industry. The annual number of houses constructed grew four fold in the thirteen years from 260,000 in

\footnotetext{
${ }^{70}$ T. Ogi, "Home building and the home-building industry", p. 198.
} 
1955 to 1.2 million by 1968 ; between 1974 and 19981.42 million homes were being constructed annually. ${ }^{71}$ A recent survey from the Japanese government's statistics showed that construction of new homes had reached 1.7 million in 1990, but had only fallen to 1.2 million by $2004 .^{72}$ These figures show that housing construction has remained at a fairly constant level over the last three decades.

The Japanese people generally prefer homes constructed of timber as decorative effect and naturalness are widely appreciated. Tamutsu Ogi pointed out that timber houses constructed in Japan today are built mainly through the use of three systems, traditional post-and-beam, prefabricated, and the two-by-four inch $(2 \times 4)$ method. ${ }^{73}$ Whilst the annual number of houses built using the traditional method dropped from 842,769 in 1974 to 446,259 in 2000 , the number built by the $2 \times 4$ method accelerated from 32,462 in 1988 to 79,114 in $2000 .^{74}$ The 2x4 method of construction was introduced into Japan from the US and by 1974 it was the major method of construction for timber homes. The liberalization of timber import tariffs in 1964 greatly facilitated this use of the imported sawn wood.

Figure 6 gives the annual house construction in Japan between 1980 and 2005. Apart from Japan's 'bubble peak' in the economy around 1990, the number of newly built houses has remained constant over the last two decades. However, the percentage of timber houses being built has dropped from 59 percent in 1980 to 43.9 percent in $2005 .^{75}$

A large part of the timber used in Japan's building construction industry is now sourced from abroad: this is particularly so in house construction where imported timber has overwhelmed the domestic industry. ${ }^{76}$

\footnotetext{
${ }^{71}$ T. Ogi, "Home building and the home-building industry", p. 198.

${ }^{72}$ Chakkō shinsetsu jyūtaku kosū (Number of new houses being built), Sōmu shō (Ministry of Internal Affairs and Communications), 2007, available at: http://www.stat.go.jp/data/nihon/g2109.htm, (accessed 5 October 2007).

${ }^{73}$ Ogi, "Home building and the home-building industry", p. 201.

${ }^{74}$ Ibid., pp. 199 - 200.

${ }^{75}$ Ringyō kankei kihon shihyō (Basic indicator for forestry related issues), Ministry of Agriculture, Forestry and Fisheries, 2005, http://www.maff.go.jp/hakusho/rin/h18/html/sanko 01.pdf, (accessed 23 July 2008).

${ }^{76}$ Ogi, "Home building and the home-buildign industry", p. 204.
} 
Figure 6: Number of new homes built between 1980 and 2005

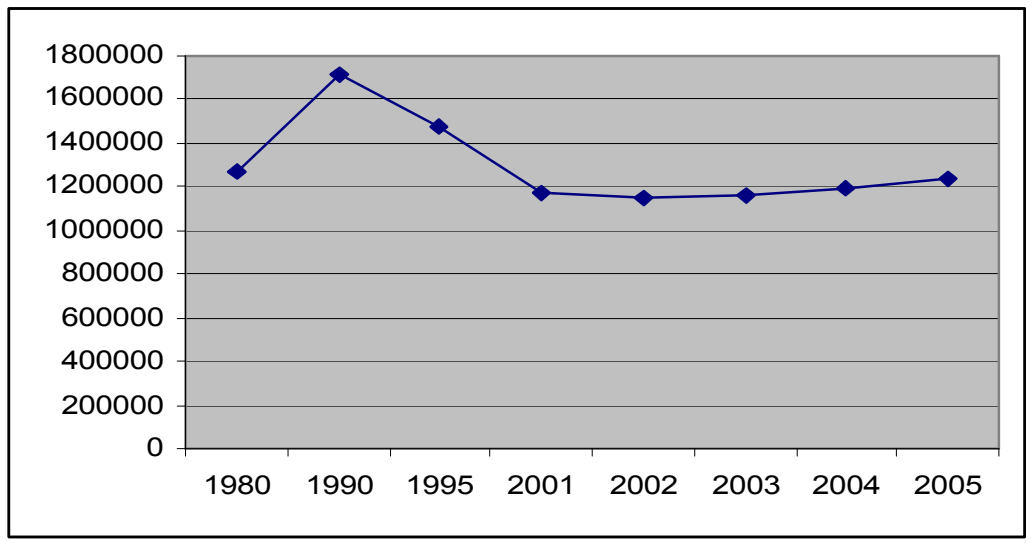

Souce: Ringyō kankei kihon shihyō (Basic indicator for forestry related issues), Ministry of Agriculture, Forestry and Fisheries, http://www.maff.go.jp/hakusho/rin/h18/html/sanko 01.pdf, (accessed 23 July 2008), complied by the author

\subsection{Paper}

As shown in Figure 5, about 40 percent of Japan's timber industry is involved in the conversion of lumber to paper and paperboard. While the building construction industry is supplied largely by imported wood, the manufacture of paper and paperboard is supplemented by the use of domestic wastepaper.

Paper has played an important part in traditional Japanese culture where the Japanese generally view it as an essential part of their heritage dating back to the $7^{\text {th }}$ century. Hideshi Noda stated that the use of paper has been one of cultural development. ${ }^{77}$ Since it commenced in the 1600s, Japanese paper making and its related industries have been economically significant and was especially so during the Meiji period. The way in which Japan's paper production developed and transformed into an important industry can be divided into three periods. The first period covers the origins of Japan's paper making.

\footnotetext{
${ }^{77}$ H. Noda, "The Japanese pulp and paper industry and its wood use", Iwai (ed.), Forestry and the Forest Industry in Japan, USB Press, Vancouver, 2002, p. 214.
} 
Japan imported the art in the $7^{\text {th }}$ century, a skill that had previously been practiced in China and Korea. Paper then became widely used in the daily lives of the Japanese from the use of shōji (traditional screen doors) in houses, to crafts, toys, and for ritual occasions. The traditional Japanese paper was a finely crafted product called washi: it was in everyday use until the 1870 s when the Western type of paper was introduced. ${ }^{78}$ Washi is made mainly from two, low bushy trees found in Japan, kohzo (paper mulberry) and mitsumata (paperbush). ${ }^{79}$ Japanese paper production using the washi method produced excellent quality paper and its manufacture was environmentally sustainable as the quantity required was able to be sourced from locally grown trees.

The second period was a major tuning point as the traditional way of paper making was replaced by mass production. It not only changed the volume of paper produced but it also changed the type of paper being made; this change occurred in the early Meiji period. There are at least two main reasons to explain the change. The first was that the new Meiji government restructured Japan's industry; it emphasized Westernization and encouraged businesses to introduce Western technologies. The Japanese paper industry took the initiative to introduce new technologies and today's leading paper companies date from that early period. The use of paper in Japan increased greatly during the Meiji period due to a greater number of newspapers being printed and the high number of translated books being published during the $1870 \mathrm{~s} .{ }^{80}$ The demand for paper was not confined to publications. Japan at that time changed its form of currency from coins to notes and this greatly increased the need for domestically produced paper.

The second factor was the change in the selection of raw materials. Whereas traditional Japanese paper used only locally grown timber, according to Noda the new Western style paper was made from rags and straw. ${ }^{81}$ Due to the increased demand, the industry decided in the late 1800s and early 1900s to use wood pulp. In 1910, Oji Paper and Fuji Paper built new mills in Hokkaido and Sakhalin where there was a reliable source of timber for wood pulp and

\footnotetext{
${ }^{78}$ H. Noda, "The Japanese pulp and paper industry and its wood use", p. 214.

${ }^{79}$ Washi no genryō (Raw material of washi), available at http://hm2.aitai.ne.jp/ row/material/material.html, (accessed 9 October 2007).

${ }^{80}$ Noda, "The Japanese pulp and paper industry and its wood use", p. 215.

${ }^{81}$ Ibid., p. 215.
} 
this enabled the mills to move into mass production. ${ }^{82}$ The domestic paper industry had already adopted mass production techniques by the time of the highly industrialized pre war period. Imports of paper peaked at 99,000 tons in 1936 and by 1940 domestic production had reached 1.5 million tons. ${ }^{83}$ The defeat of Japan in 1945 and the occupation of Sakhalin by the Soviets resulted in a reduction in paper production; by 1946 it had dropped to 210,000 tons. ${ }^{84}$ The industry made a number of changes in the post war period; it switched from using domestically sourced hard and softwood timber, to imported lumber, and it moved away from importing logs to importing wood chips.

The third period occurred in the 1960s when Japan's paper industry adjusted to several changes. As mentioned, the government liberalized timber imports and this led to a gradual increase in imported wood chips. As a percentage of total use, pulpwood imports increased from 19 percent in 1970, to 38 percent in 1985, and to 67 percent in $1997 .{ }^{85}$ The high value of the Yen meant that Japan could import wood chips relatively cheaply, which led to the decline of the domestic waste paper industry; particularly after the second oil shock in 1979 the waste paper industry could not survive against the competitiveness of the world waste paper market (see Figure 7). ${ }^{86}$

\footnotetext{
${ }^{82}$ Noda, "The Japanese pulp and paper industry and its wood use", p. 216.

${ }^{83}$ Ibid., p. 216.

${ }^{84}$ Ibid., p. 216.

${ }^{85}$ Ibid., p. 219.

${ }^{86}$ Koshi shijō kasseika ni tsuite (Revitalization of waste paper market), available at http://seminar.econ.keio.ac.jp/shimada/paper/ap/ap-1.pdf, (accessed 10 October 2007).
} 
Figure 7: Changes in the price of waste paper (1972-1999)

(Unit: $¥ / \mathrm{kg}$.)

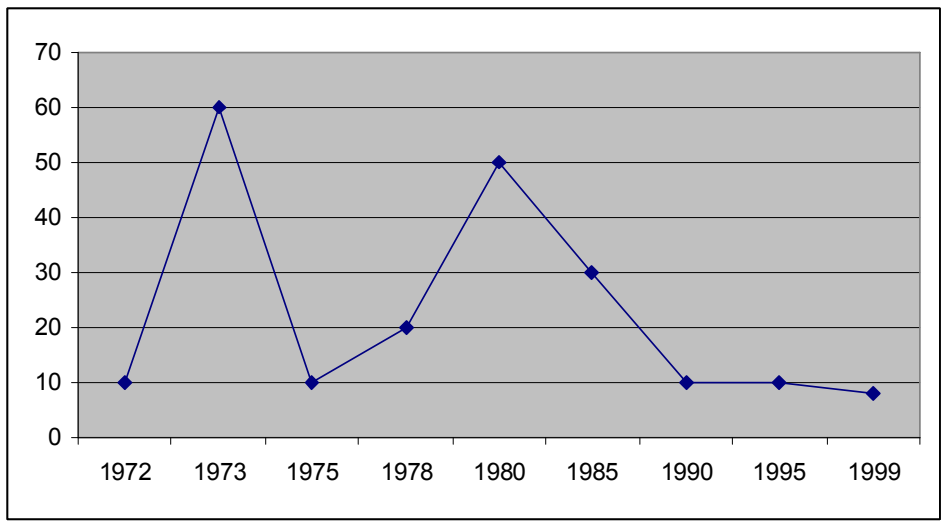

Source: Koshi shijo kasseika ni tsuite (Revitalization of the waste paper market), compiled by the author

In the early 1990s, amid rising global environmental concerns, the Government enacted the 1991 Recycling Law to promote the use of waste paper and Japan's paper industry now became a vigorous exporter of waste paper, mainly to neighboring Asian countries (see Figure $8)$.

Figure 8: Destination of Japan's waste paper exports (Unit: \%)

\section{NOTE:}

This figure is included on page 235

of the print copy of the thesis held in the University of Adelaide Library.

Source: Waste paper exported by Japan Paper Association, available at http://www.jpa.gr.jp/states/used-paper/index.html, (accessed 10 October 2007) 


\section{Concerns over illegal logging}

It goes without saying that the practice of illegal logging is unethical. At the $2000 \mathrm{G} 8 \mathrm{Summit}$ in Okinawa, Japan, the Japanese government announced a very clear principle that, "illegally harvested timbers should not be used" ${ }^{87}$ It can be said that action over illegal logging is never too late, but with Japan it was a case of too little for too long. The illegal activity costs the world economy between $\$ 10$ and 15 billion dollars a year ${ }^{88}$; this is not only a problem for the forestry industry, but it also has social, environmental, and economical consequences. The activities and results of illegal logging are complex; it encompasses corruption, theft of public land, diversion of revenues, and other illegal appropriations of public assets. ${ }^{89}$ Any involvement in illegal logging is a morally corrupt action; this applies particularly to corporations and governments that knowingly turn a blind eye to this practice and those bodies deserve the odium that they receive. Japan's MOFA has however participated in some international meetings such as the G8 Summit of 1998 in order to combat the practice.

If commercial logging is the main reason for deforestation in many of the developing regions, then illegal logging is the main culprit for vanishing tropical rainforests. It is estimated that in 2004 around 70 percent of timber harvested in Indonesia was from illegal logging and has led to an annual deforestation of 2 million hectares; ${ }^{90}$ the proportion of illegal logging is expected to reach 80 percent. -Illegal logging should be stopped as it is not only about depleting timber resources and the loss of revenue to the supplying country, it is also about concern for the forest environment, the forest ecology, and the forest's endangered species.

\footnotetext{
87 “Waga kuni no torikumi nit tsuite (Our country's strategy)”, The Forestry Agency, 2007, http://www.rinya.maff.go.jp/policy2/ihou/torikumi.html, (accessed 25 September 2007).

${ }^{88}$ R. Hembery, A. Jenkins, G. White and B. Richards, "Illegal logging, cut it out!", The UK's role in the trade in illegal timber and wood products by WWF UK in January 2007, http://www.org.uk/filelibrary/pdf/logging full report01.pdf, (accessed 25 September 2007).

${ }^{89}$ Corruption often cause of environmental damage, by Illegal-logging info., 24 August 2004, available at http://www.illegal-logging.info/item single.php?item=news\&item $\mathrm{id}=458 \&$ approach $\mathrm{id}=1$, (accessed 5 November 2007).

${ }^{90}$ Ibid.
} 
The Japanese government responded to the problem of illegal logging by stipulating binding directives in its departmental manuals. However, these directives are interpreted differently by the various government authorities. The MOFA views illegal logging as a hindrance to a sustainable forestry management system, ${ }^{91}$ whereas the Forestry Agency maintains that the practice is against the regulations in the host country and that there is a definite responsibility on the part of the country that imports that timber. ${ }^{92}$ The environmental organization Greenpeace has a more wide ranging critical view of the activity; it argues that revenue from illegal logging activities contributes to organized crime and money laundering, and that it poses a threat to international security. ${ }^{93}$ However, both the MOFA and the Forestry Agency just follow mandatory regulations rather than to take the initiative to accept a moral responsibility to combat the illegal practice. The Government enacted a law in 2005, named Gurīn kōnyu $\bar{u} \bar{o}$ (Law on promoting Green purchasing) that provides guidelines for measures to encourage purchasing eco-friendly goods and products. However, Greenpeace Japan argues that in regard to illegal timber, the Gurin kōny $\bar{u}$ ho does not specifically regulate its importation; although the law requests proof of legitimization, the way it verifies the proof is questionable. $^{94}$ The Japanese government prefers to enact laws to stress the importance of buying legal timber, and to persuade consumers and businesses to buy ecologically friendly products.

In January 2003 the Indonesian Minister for Forests, Muhammed Prakosa, made a critical but honest comment on illegal logging. He said, "Expecting or asking one country to combat illegal logging, while at the same time receiving or importing illegal logs, does not support the efforts to combat these forest crimes. In fact, allowing the import and trade of illegal timber products could be considered as an act to assist or even to conduct forest crime". 95 That the situation today is still quite bleak and is an ongoing problem was revealed in an Australian

\footnotetext{
${ }^{91}$ Iho bassai mondai (Illegal logging issues), the Ministry of Foreign Affairs, http://www.mofa.go.jp/mofaj/gaiko/kankyo/bunya/bassai.html, (accessed 5 November 2007).

${ }^{92}$ Iho bassai taisaku (Illegal logging countermeasure), the Forestry Agency http://www.rinya.maff.go.jp/policy2/ihou/taisaku.html, (accessed 5 November).

${ }^{93}$ Illegal logging - destroying the last ancient forests, Greenpeace International, http://www.greenpeace.org/international/campaigns/forests/threats/illegal-logging, (accessed 5 November 2007). ${ }^{94}$ Ihō bassai mokuzai wa yunyū subeki de wa nai to yaku hachi wari ga kaitō (About 80 percent agreed that Japan should no import illegally logged timbers), Greenpeace Japan, 24 April 2006, http://www.greenpeace.or.jp/press/releases/pr20060424a html, (accessed 26 March 2009).

${ }^{95}$ Greenpeace, Illegal logging - destroying the last ancient forests.
} 
newspaper report of November 2007. It said, "The Indonesian President Susilo Bambang Yudhoyona is facing increasing pressure to sack his present Forestry Minister, Malem Sambat Kaban, as the scandal around a fugitive illegal logging tycoon mounts". 96 The Minister is accused of aiding the fugitive to escape criminal charges over illegal logging. Further, a 2007 report by the UN estimates that if the present trends continue, 98 percent of the Indonesian rainforest would be gone by $2012 .^{97}$ Bio fuel companies wanting to create palm oil plantations prefer to log old growth forests for an immediate financial return rather than to follow the Indonesian government's directive to use cleared land. In the early 1990s, the Japanese government quite clearly avoided sharing any blame in regard to deforestation concerns. Saburō Kato, the director general of the Global Environmental Department at the Environmental Agency at that time, rejected the accusation of Japanese accountability. He argued that "on the whole, the loss of tropical timbers is due to population growth in developing countries, where people slash down trees and burn them to survive". ${ }^{98}$ The population increase in some of the developing countries has certainly had a negative effect on their forest environment, but the main cause is the high demand for timber and wood products from the developed nations. Furthermore, the massive debts that the poorer countries have accumulated due to pressure from the wealthy developed countries to engage in costly projects that have not delivered the promised rewards, have forced them to turn to quick and ready methods of repaying the debts, this often done through unsustainable logging. Iwai and Yukutake pointed out that the Japanese government equipped major overseas harbors with necessary amenities such as wharves and facilities, and that these have greatly helped exports to Japan, especially that of timber. ${ }^{99}$ This government assistance is a part of Japan's ODA to help improve the capabilities of those countries that export to Japan, but it nevertheless assists Japanese trading companies. Japan's timber trading includes illegal timber supplied from Indonesia: the logging has caused tremendous damage to the forests in some regions of the country. In 2005, M.S. Kaban, the Minister of Forestry of the Republic of Indonesia, announced that 2.8 million hectares of forest land have been destroyed annually. 100

\footnotetext{
${ }^{96}$ S. Fitzpatric, "Forests felled for bio-fuel boom." The Weekend Australian, 10-11 November 2007.

${ }^{97}$ Ibid.

${ }^{98}$ A. Coghlan, "The Green Empire”, New Scientist, vol.140, no.1893, 2 October 1993, p. 50.

${ }^{99}$ Y. Iwai and K. Yukutake, “Japan's wood trade”, p.251.

${ }^{100}$ Shinrin hakai no hanzai (Crime of forestry devastation), Crime File II, Greenpeace Japan, http://www.greenpeace.or.jp/campaign/forests/documents/doc060411.pdf, (accessed 26 March 2009).
} 
Furthermore, he added that in 2004 the illegally harvested timber had cost Indonesia US \$4 billion, ${ }^{101}$ a significant economic and social cost. For instance, Kayu Lapis Indonesia is a major timber supplying company in Indonesia that has connections with affiliated companies that deal in illegal timber. ${ }^{102}$ Greenpeace Japan stated that there are three Japanese trading companies, Tōyō Material, San Kenzai and Mitsui Sumitomo Kenzai, involved which knowingly import illegal timber from Indonesia. ${ }^{103}$ The Japanese government's 2006 Gurīn $k \bar{o} n y \bar{u} h \bar{o}$ has failed to prevent this unethical practice and there are concerns that this timber will penetrate into Japan's domestic market. The Sōgo Shōsha's practices, along with the government's soft regulations, make a mockery of combating illegal logging and protecting tropical rain forests.

\section{The ethics of the Forestry policy and of Japanese corporate practices}

Japan's forestry policy reflects the preference of the Japanese government to direct its policies by the use of regulations and binding laws. The policy has continued to focus on productivity within the Japanese forestry industry, due to global environmental initiatives which the government has since the 1980s consciously incorporated an 'environmental' element in its policies. Having said that, the government's focus on so called 'green management' places a greater weight on economics than on preservation. This short section will look at ethical elements relating to forestry issues. Firstly, the government policy needs to contain ethical considerations in order to make sound management decisions. Secondly, corporate Japan in general fails to include a moral consciousness in its business plans and practices. Many founders of Japanese big business in the Meiji era emphasized social and moral values when conducting business, but this precept appears to be fading away in modern Japan.

\footnotetext{
${ }^{101}$ Shinrin hakai no hanzai (Crime of forestry devastation), Crime File II, Greenpeace Japan. ${ }^{102}$ Ibid.

${ }^{103}$ An inquiry letter to the Japanese companies, Greenpeace Japan, 24 April 2006. http://www.greenpeace.or.jp/campaign/forests/documents/doc060424c.pdf, (accessed 27 March 2009).
} 


\subsection{Ethics of the forestry policy}

To define what ethics entails in forestry matters is not simple. Environmental philosophers and ethicists have stated the necessity of an ethical consideration in forestry issues, but none have clearly identified the nature of those ethics. The United Nations Conference on Environment and Development (UNCED) held in Rio de Janeiro in June 1992 attempted to define a so called 'forestry principle'. Principle 2 (b) of the UNCED states: "Forest resources and forest lands should be sustainably managed to meet the social, economic, ecological, cultural and spiritual needs of present and future generations". ${ }^{104}$ The definition given by the UNCED specifies that in forestry issues, sustainability is the key consideration.

In global environmental issues the cliché 'sustainable development' remains a popular catchphrase: however the neologism has come to have a greater emphasis on economical development rather than on ecological-social development. Forestry practice is an ethical issue and policy makers need to employ the principle of sustainability in its true sense. Sustainability encompasses not only the timber industry but also the ecological and cultural environment of the forests. Within environmental ethical theory there are two aspects of a forestry policy: consideration from an anthropocentric and from a non-anthropocentric view. Hugh Williams stated that the definition of good forestry means that firstly, forests should benefit human beings by serving their needs, and secondly, forests should serve the needs of its own ecosystem. ${ }^{105}$ It is essential that the Japanese government along with the Sōgo Shōsha see that sustainable practices are followed. The government has an obligation to protect the viability and well being of its domestic forestry industry, and to ensure responsible action by Japanese corporations in their overseas timber activities.

One of the first moral considerations that needs to be taken into account in a forestry policy is the potential for people who inhabit the forests to be displaced. Large corporations that do not apply an ethical code frequently exploit forest resources forcing forest dwellers to move due to

\footnotetext{
${ }^{104}$ Report of the United Nations Conference on Environment and Development, Rio de Janeiro, 3-4 June 1992, available at: http://www.un.org/documents/ga/confl 51/aconf15126-3annex3.htm, (accessed 4 January 2008).

${ }^{105} \mathrm{H}$. Williams, "What is good forestry? An ethical examination of forest policy and practice in New Brunswick", Environmental ethics, vol. 18, no. 4, 1996, p.393.
} 
the destruction of their habitat. This situation is brought about by a monetary perspective focused on profits. Sustainability is only considered from an economic viewpoint, little consideration is given to the function that trees serve for indigenous people and for the forest ecosystem. It is not often realized just how many people are directly dependent on forests for their livelihoods. The Food and Agriculture Organization of the United Nations (FAO) states that forests are the home to 300 million people around the world, ${ }^{106}$ roughly equivalent to the 2007 population of the United States. Furthermore, the FAO believes that about 1.2 billion people in the developing countries rely on agroforestry (a combination of agriculture and forestry that maintains sound and sustainable land management) to help sustain their agriculture and income. ${ }^{107}$ These people represent approximately one quarter of the world's population. The indigenous people who live in the forests have the greatest appreciation of them and are totally dependent on the forests for their livelihoods.

A second consideration is the intangible value of the woodland environment, forests and the natural world which are inseparable. Forests do not comprise just a collection of trees: they house indigenous people, animals, plants, and water storage properties; these elements all shape and contribute to their richness. Biodiversity is an important element in maintaining a sustainable viable forestry industry and the FAO pointed out that forests provide habitats for around two thirds of all species on earth. ${ }^{108}$ This clearly illustrates their significance. The vision of conservationists and preservationists on the forestry environment are somewhat different. The environmental philosopher Joseph DesJardins, pointed out that the conservationist's point of view is that the natural environment is a valuable resource to serve human interests, whilst the preservationists view is that leaving the wilderness alone also serves human interests. ${ }^{109}$ However, it could be argued that an ethical judgment on forest use still centres on what human beings can and should do.

\footnotetext{
${ }^{106}$ People and forests, Food and Agriculture Organization of the United Nations, available at: http://www.fao.org/forestry/site/28811/en/page.jsp, (accessed 12 October 2007). 
It is important to fully recognize the value of forests to the earth's environment. People in developed countries see forests as a valuable source of lumber rather than as a valuable contributor to the global ecosystem: thus the environmental value of the forests is eclipsed. This self-interest gives them a different perspective on forests than that of the forest inhabitants. Alastair Gunn argued that "we are seen as having no concern for their affairs except when our self-interest is affected". ${ }^{110}$ Value placed on the forests is value placed on the environment; it follows then that a sustainably managed forestry practice ensures the well being of the ecosystem.

\subsection{Japan's corporate ethics - a paradox}

This section firstly examines the corporate ethics of the Japanese trading companies, and secondly considers whether ethics in relation to the environment are applied in forestry management. As briefly explained under ethics in Chapter two, Dōtoku is seen in Japan as a set of moral principles based on Confucian thought. Eiichi Shibusawa (1840-1931), a Japanese thinker and entrepreneur, dealt with issues of business and morality from a Confucian aspect. His philosophy still has an influence in corporate ethical thought which in part asserts that company profits should also benefit the community. The Mitsui Corporation and Sojitsu Corporation are both dominant timber import companies. Mitsui states that its philosophy is to be fair, humble, and faithful; it emphasizes that trust demands the highest ethical conduct in society. ${ }^{111}$ Sojitsu stresses environmental and social responsibility: it believes that it is important that environmental conservation and a sustainable society co-exist with economic development. ${ }^{112}$ These philosophical principles are often advocated by the major trading companies and also by smaller Japanese companies.

\footnotetext{
${ }^{110}$ A. Gunn, "Environmental ethics and tropical rain forests: Should greens have standing", Environmental ethics, vol. 16, no.1, Spring 1994, p. 22.

111 "Philosophy and principles" by Mitsubishi Corporation, 1 May 2006, available at: http://www.mitsubishicorp.com/jp/en/about/philosophy/, (accessed 5 November 2007).

112 "Environment and social responsibility", Sojitz Corporation, available at: http://www.sojitz.com/en/corporate/environment/index.html, (accessed 5 November).
} 
Traditional moral principles in Japan also emphasized social responsibility. In recent years Kigyō no shakai teki sekinin (Corporate Social Responsibility) has been widely discussed among the Japanese due to scandals that range from date extension on food products to bid rigging; it stresses the importance of responsible behavior and practice. Within Japan the previous mind set of absolute loyalty to the company has started to lessen; the Japanese are now placing a greater value on social justice. ${ }^{113}$ Even though the Japanese society has become highly modernized, the populace desires to hold onto the old fashioned value of human interactions within their families and their communities; this is the foundation of Japanese ethical conscientious.

Many Japanese business entrepreneurs have emphasized the importance of ethics in the corporate world. Kōnosuke Matsushita, the founder of Matsushita Electric Company (also known as National or Panasonic) who contributed greatly to the economic prosperity of the post war Japan, valued religion and ethical behavior. Matsushita believed that human happiness will continue if it contains the two elements of emotional stability arising from religious morality, and the sustainability of material needs. Entrepreneurs have the responsibility to serve the society. ${ }^{114}$

The Japan External Trade Organization reported that the reason for the unveiling of the numerous scandals that have brought into question corporate ethics was the increase in the number of 'whistle blowers'. ${ }^{115}$ Whilst whistle blowers have challenged and exposed domestic corporate malpractice, this has not happened with Japanese employees abroad. In the overseas trading operations, the Sōgō Shōsha employees working with their counterparts, and with their keiretsu, have a strong sense of loyalty to their parent companies. The results are that in the timber industry immoral and unethical activities are not usually disclosed. This degree of loyalty not only destroys the forest environment, but also calls into question the

\footnotetext{
113 "Corporate ethics, businesses beef up their compliance programs", Japan External Trade Organization, Focus Japan, December 2002, available at: http://www.jetro.go.jp/thailand/e/data/corporate ethic.pdf, (accessed 6 November 2007).

${ }^{114}$ Katsujirō Koga, “Keizai to Dōtoku, kigyōka tachi no shisō (Economy and morality, an entrepreneur's thoughts)", Ningen kaigi, December 2003, p. 25.

115 Japan External Trade Organization, "Corporate ethics, businesses beef up their compliance programs", in Focus Japan, December 2002, available at: http://www.jetro.go.jp/thailand/e/data/corporate ethic.pdf, (accessed 6 November 2007)
} 
application of the Japanese code of corporate ethics. It would seem that all too often corporate ethics and company philosophies do not extend to their overseas business enterprises; they stop at Japan's borders. In spite of challenges over recent years by international organizations such as Greenpeace and Friends of the Earth, they have had little influence on corporate ethical thought.

It could be said that, rather than adhering to the notion of Japanese environmental ethics, Japan's corporate philosophy and forestry/environmental policy are guided by the goal of profit. Ethics based on cultural and empirical values should respect the significant and priceless non economic value of the environment. The Japanese who experienced the catastrophic environmental pollution in the mid $20^{\text {th }}$ century have developed an ethical responsibility towards the environment. This, however, does not seem to be the case with timber corporations; their narrow viewpoint is that forests are for sourcing timber, rather than that they are an essential ecosystem on which the world relies. A managed forestry policy that ensures sustainability of all its components is the key to preserving the forests for future generations.

\section{Conclusion}

The ethics of Japan's timber trade policy can be judged from two perspectives. The first is from its effect on Japan's domestic forests and forestry industry, and the second is from its effect on the global ecosystem, that includes the wellbeing of the indigenous people living in the forests from where Japan obtains its timber. If a government policy exhibits an immoral shortsightedness and a bias towards vested interests, then that policy can be deemed to be unethical.

Although the Japanese government used its demobilized soldiers in 1946 to implement a massive re-afforestation program, little consideration was given to the long term husbandry needed to see the forests through to the felling and milling stage, or to their subsequent replanting. Japan's rapidly developing industrialization gradually soaked up the cheap rural 
labor and this added to the difficulties of an industry that was located in mountainous and difficult terrain. When these forests were able to generate an income, the central government put the proceeds into its general account; as a consequence, when the domestic industry needed fiscal assistance, the national forest account had insufficient funds. This neglect, and the fact that the domestic industry was small, fragmented, and unable to adapt to changing demands, accelerated its decline. Adding to its problems, the central government favored big business in its drive towards economic growth and eased restrictions on imported timber; this together with the strong Yen made the abundant overseas timber cheaper than the home product. The government of the long ruling LDP sacrificed the domestic forestry sector in order to benefit those who kept it in power, big business.

Japan's Sōgō Shōsha and their keiretsu established huge global networks in their quest for overseas lumber, with the central and local governments aiding them with infrastructure projects such as ports and timber storage facilities. Japan's remarkable post war economic recovery was attained in the main by processing tremendous amounts of imported raw materials, and timber was a significant part of it. As a result of excessive logging world wide, the global environment, forestry viability, business principles, and fundamental human rights, have become victims. Over-exploitation of overseas timber resources by Japanese corporations, with the encouragement and support of the government, shows that neither fully respected the non timber value of forests. The close relationship of politicians with the Soggo Shōsha suggests that the LDP government cannot avoid the accusation that it acted in an unethical way. Forests are first and foremost viewed as an exploitable resource; little attention is given to the role that they play in the global ecosystem, or to the beings that depend on those forests.

The moral bankruptcy of the government's timber policy is shown further by its weak stance against the importation of illegal timber, and all that that entails. The government's own data verifies this practice, but its lack of affirmative action to curtail this activity is additional proof that the forestry policy is lacking in ethical content. 


\section{CONCLUSION}

This conclusion details the assessment of the enquiry into the ethical essence of Japan's global environmental policies. The analysis has shown that the policies have not employed an adequate ethical framework from the perspective of both Western and Japanese environmental principles. Environmental agendas are a relatively new concept for most countries. Japan's domestic environment policy was only legislated in 1972 and came as the result of pressure from citizens at the grass roots social level who were alarmed about the deteriorating condition of their environment. Their concerns were triggered by the nation's catastrophic environmental pollution crises resulting from the government's determined and narrowly focused drive towards economic development. The Japanese global environmental policy took life in the 1980 s when the country's economy was growing significantly and Japan was benefiting from the enormous amounts of raw materials that it was importing and in which it was singularly lacking. While the domestic environment policy was brought about by local social pressures, Japan's global environmental initiatives were the result of a global environmental awareness, especially among industrialized nations. Japan quickly adopted sustainable development as the aim and philosophy of the initiatives, but at the same time the policy accommodated business operations; it was designed not to jeopardise them but to support their sustainability. Japan's global environmental policy initiatives present contradictory features. For instance, the policy has shown a positive responsibility such as the setting up of the environmentally related Official Development Assistance (ODA) program designed to assist developing countries, and the hosting of the United Nation's Kyoto Conference on Climate Change in 1997. However, in spite of affirmative commitments from that time, a number of government policies, including those in the three case studies, do not uphold the Japanese promises to protect and conserve the environment and to ensure the sustainable use of world resources.

The examination of the three case studies proved the absence of adequate ethical consideration in these government policies. Although the case studies involve different raw materials, they have the common aim of maximising the 'utilization of resources'; importantly these are resources acquired from outside of Japan. The policies display 
different aims and frameworks but are connected in that they each have an effect on the global ecosystem. As such, the preservation and sustainable management of that ecosystem is the key to a responsible government policy.

The enquiry into the first case study, that of the whaling policy, has shown that the Japanese government sees whales as a resource to be used rather than as a marine species to be protected. The policy takes the narrow view of the commercial value of whales and fails to acknowledge their significant value in the marine ecology. Today's whaling policy largely consists of the scientific research program that has over the past two decades killed more than 10,000 whales. This flies in the face of the fact that with the availability of modern research methods, it is no longer necessary to carry out lethal methods to research the species. The government's continuing rhetoric about the justification for a resumption of pelagic commercial whaling reveals the determination of the vested interests of the Fisheries Agency, the Institute of Cetacean Research, and the Japan Fisheries Association. A study of the history of Japan's fishing industry reveals a failure to engage in a way that ensures sustainability of the marine stocks; the industry rarely shows restraint in its activities and in far too many instances when one source has been depleted, it then moves on to another. A further moral judgement can be made on the probity of spending large sums of money from the public purse on the scientific program where the major benefits go to vested interests, rather than to the general community. Whether commercial whaling is resumed or not, the beneficiaries of the tax payer funded program remain largely with Japan's fisheries organizations. This feature highlights the unethical aspect of the financial side of the program, quite apart from the humanitarian aspect of killing whales.

In the second case study, the nuclear energy policy, the enquiry revealed that it also is lacking in adequate ethical considerations. The importance of nuclear energy to Japan's economic survival was evidenced in 2007 through its use of 55 light water power reactors to feed into the electricity grid. However, this reliance discounts the fact that the nuclear energy policy fails to place an adequate value on social considerations and on the environment. The nuclear energy industry is largely promoted by Japanese corporations; it is shaped by economic considerations and it is driven by technological preferences. As with the whaling policy, the nuclear energy policy has been shaped and developed by a ruling triad, in this case the Ministry of Economy, Trade and Industry (METI), the Ministry of Education, Culture, Sports, Science and Technology, and the Japan Atomic 
Industrial Forum. The role of the triad is extremely important in that it is the voice of Japan's nuclear industry and can be described as 'Japan Nuclear Inc.'. Ecological concerns aside, of considerable concern are the astronomical sums of public money that are being poured into Japan's nuclear energy businesses. The government has given an annual subsidy to the industry of around $¥ 500$ billion; this funding goes to companies involved in nuclear research and technology. ${ }^{1}$ Furthermore, in 2008 the government allocated $¥ 13$ billion for the development of the next generation reactors. ${ }^{2}$ There is no question that finance is a major factor in the present power game of the nuclear industry, but it will also be a major factor in the legacy of using nuclear energy. Little consideration is given to the financial burden of coping with the toxic after-effects of disused plants and nuclear waste that will be passed onto future generations, the operations from which they will have received no benefit. Gavin McCormack noted that the indifference to a financial debt that will be passed on is emphasized by the fact that in 2007 Japan's national debt stood at 21 years of tax revenues at their present level. ${ }^{3}$

A further concern is Japan's accumulation of plutonium from its nuclear reactors; apart from the financial and environmental cost of storing the hazardous waste, there is the potential for its use in the manufacture of military weapons. Japan's plutonium stockpile is already a strategic asset and, notwithstanding Japan's 'peace' constitution, prominent politicians have canvassed the possibility that Japan could justify acquiring a nuclear weapon capability. Whether the nuclear energy policy is considered from the viewpoint of its bequest to the human and natural world, from its potential to allow nuclear weapons production, or from the vast amount of money that is being spent for present day energy needs, any policy that promotes its use is ethically deficient.

The third case study, the domestic forestry and timber trade policy, reveals a similar pattern as seen in the other two case studies; vested interests within an Iron Triangle, in this case the Forestry Agency, the METI, and Japan's Sōgō Shōsha, dominate and dictate policy direction. Japan's important industries of construction and manufacturing are now totally reliant on imported timber for their survival; the overseas timber trade policy and

\footnotetext{
${ }^{1}$ H. Koide and A. Adachi, Genshiryoku to kyōzon dekiruka (Can we live together with nuclear power?), Kamogawa shoten, Kyoto, 1997, P. 136.

2 "Mitsubishi to develop Japan's next fast breeder reactor", World Nuclear News, 18 April 2007, http://www.world-nuclear-news.org/newNuclear/180407-

Mitsubishi to develop Japan s next fast breeder reactor.html, (accessed 18 January 2008)

${ }^{3}$ McCormack, Client State: Japan in the American embrace, Verso, London, 2007, p. 45.
} 
practices raise questions of morality of intent. The all-powerful Sōgō Shōsha and their overseas keiretsu chain dominate the industry and keep the price of timber artificially low, with the consequence that the exporting countries are deprived of equitable royalties.

Illegal logging is the main culprit for vanishing tropical rain-forests and, although the Japanese government outwardly condemns the practice, it has been seen to be complicit in the activity. Apart from the costs to the world economy of around US\$13 billion dollars a year, ${ }^{4}$ there are added to that the social and environmental costs that impact severely on the forest dwellers in those regions where the timber is logged and who depend on those forests for their livelihood.

Japan's forestry policy shows a preference for regulations and binding laws: however, defining ethics in forestry issues is not a simple task and ethical considerations are an imperative. The ethics of the forestry policy can be judged from the fact that Japan actively protects its own woodlands that cover 70 percent of the country, whilst at the same time it imports massive amounts of timber from far less affluent countries. The inequalities in the forestry policy are articulated in a succinct critique by Shunya Yoshimi where he stated that "the opulence enjoyed by many Japanese today is the product of countless expropriations and displacements against nature and the Third World. It is something to which we possess no legitimate right". 5

This section of the conclusion is an appraisal of the analysis of the central arguments. I have established through the three case studies that 'sustainable development' is the central philosophy that drives the Japanese policies, but that it is in fact a cliché. However, although Japan's policies purport to demonstrate a responsible management approach through the application of this platitude, in practice they fail. The analysis of the Japanese domestic and global environmental policies, along with the three case studies, has shown that the policies are ethically deficient with respect to two main features. In the first instance, the policies are driven and directed for the benefit of vested interest groups who ensure that their wellbeing is accommodated in the matter of guidance, compromise, negotiation, and self-regulatory behaviour. In the second instance, the policies discount

\footnotetext{
${ }^{4}$ R. Hembery, A. Jenkins, G. White and B. Richards, "Illegal logging, cut it out!", by WWF UK in January 2007, http://www.org.uk/filelibrary/pdf/logging full report01.pdf, (accessed 25 September 2007).

${ }_{5}^{5}$ G. McCormack, The emptiness of Japanese affluence, Allen \& Unwin, NWS, 1996, p. 100.
} 
and/or ignore responsibilities for the future; short term goals override any consideration of intergenerational fairness.

In this thesis the presupposition is that in relation to the environment, an ethical practice is one built on the premise of 'a sustainable routine', one that will continue more or less indefinitely into the future. Where these practices involve resource extraction and harvesting, it is crucial that they ensure the security of the wellbeing of the global ecology. This thesis has exposed the ethical deficiency of the Japanese policies from both a Western and from a Japanese perspective in that they have ignored environmental responsibilities and obligations. Japan's traditional respect and reciprocal care for the natural world has also been cast aside in the implementation of these policies.

One of the key findings in this thesis is the revelation of who the players are who direct the government's policies. The dynamics of the policy formation rests with Japan's Iron Triangles where vested interest groups govern the policy direction.

The first dynamic (player) is generally the Sōgo Shōsha; these trading companies are a carry-over from the pre-war zaibatsu financial conglomerates and are at the centre of Japanese business activities. Their interlocking structure and world wide influence through their keiretsu give them an enormous advantage when it comes to business opportunities, and this is particularly true with resource procurement.

The second dynamic has been the political power of the long ruling LDP; the party's domination of Japanese politics in the past has ensured that its interests and influence were an integral part of the Japanese economy. The largesse passed down from the central government through its political connections to the village level resulted in government environmental policies being tailored to meet these expectations. The outcome was a severely compromised policy.

The third dynamic is the government bureaucracy. This institution has developed a very cosy relationship between its bureaucrats and big business through the amakudari system whereby bureaucrats can parachute into rewarding positions when they leave government. As they bear these opportunities in mind, government officials will not take a hard line 
against business and the party in power when they develop the policies; the consequence is that concessions are made that weaken the intent of the policies. In the three case studies these three entities are the dynamics that comprise the Iron Triangles.

The Japanese government has set stringent regulations within the country to combat domestic environmental problems and it has successfully encouraged the community to be involved in national environmental schemes where the participation rate is quite high. Although the players within the triangles have influenced Japanese environmental policies, Japan has been successful in promoting global environmental initiatives. Japan's contributions have without doubt been of benefit to the environment, but they have also been of benefit to the Japanese themselves. There are three reasons for this involvement. First, the government has set its sights on becoming a world leader in environmental pollution control through its technological expertise; it wants to share the experience and knowledge that it gained from the effects of the post WWII kogai. Second, the government wants to promote Japan as a 'Green Conscious Nation' through the willingness of its people to be involved in public resourcefulness. Thirdly, the government wants Japanese companies to expand their business opportunities by participating in Japan's environmental policy programs. In spite of lofty ideals, many of the policies that impact on the natural world fail to appreciate the necessity of protecting, conserving, and sustaining environmental integrity. In the environmental policies and in the three case studies, this failure can be attributed to the manipulative and political hand of the Iron Triangles.

This thesis has identified and articulated the Japanese model of environmental ethics and has compared it to the Western model. The Western code was built on the foundation of an academic, philosophical branch of understanding with an emphasis on rights, justice, and fairness in environmental issues; it exhibits a somewhat detached, one-way approach to the environment. The Japanese code was built on empirical values and experiences and placed a strong emphasis on a reciprocal relationship; it stressed compassion, care, respect, and togetherness with the natural world. The comparative analysis of the Western and Japanese codes of ethics has revealed similarities as well as distinctive differences. Religion has played an important part in the development of both codes, although they have led to different outcomes. Whilst the Western code espouses a philosophical view of respect and responsibility towards the environment which includes animals, the Japanese 
code is much broader and emphasizes reciprocal interaction and care between humans, between humans and nature, and between humans and animals. In the West this consciousness developed from a combination and merging of philosophical ethical theories; essentially a 'top down' approach. In Japan it grew from the interaction at the grassroots level of koggai victims, medical doctors, scholars, and the empirical values that are encapsulated in Minamata-gaku: it is a 'bottom up' approach. Japan's rich cultural traditions and religious practices has in the past fostered a special reciprocal relationship between the Japanese and their environment; this relationship has however been marred by outside dynamics that have influenced the integrity of government policies.

Japanese environmental policies today seem no longer to uphold these ideals; all too often problems have been dealt with by political and scientific approaches that omit or avoid the ingredient of philosophical wisdom and of ethical values. The policies in the three cases studies show a similar failure to uphold traditional ideals; they have been shown to be corrupted by vested interests.

An ethical consideration is a guide for the future. Policies that impact on the environment must include a moral obligation to guarantee future generations an equitable share of the earth's bounty. A core requirement in policies that use natural resources is to ensure 'sustainability'; it is not necessarily a restriction, but it is a balance between consumption and conservation. The Japanese policies examined in this thesis do not show this balance and fail to include an appropriate level of ethical consideration.

Finally, the thesis has attempted to evaluate Japan's global environmental performance through the three case studies; it has shown that the Japanese policies fail to incorporate sufficient ethical considerations and the power players behind the policies that have contributed to this deficiency. The thesis has opened the door to future research in an area that has received little attention from scholars and environmental philosophers, the development of a comparative theory on Japanese environmental ethics. This enquiry would explore the Japanese perception and understanding of environmental ethics in the context of rinri. This could lead to a new assessment of environmental performance and government policy making judged from a Japanese perspective and not just from a Western position. 


\section{BIBLIOGRAPHY}

Advertiser, 17 October 2008, p. 35.

Agency of Natural Resources and Energy 資源エネルギー庁 (2001) 総合資源エネルギ 一調査会からのメッセージ: Sōgō shigen enerugī chōsakai kara no messēji (Message from the General Natural Resource Energy Investigation Committee).

(2001 - 2002) 高レベル放射性廃棄物の処分について: Kō rebel hōshasei haikibutsu no shobun ni tsuite (About disposal of high level radioactive waste).

(2006) 2007 年度「原子力立国計画」関連予算の概要: 2007 nen do 'Genshiryoku rikkoku keikaiku' Kanren yosan no gaiyo (Outline of the related budget of 'nuclear state plan' in 2007),

http://www.enecho.meti.go.jp/policy/nuclear/pptfiles/070111a.pdf, (accessed 11 January 2008).

Agency of Science and Technology 科学技術庁 (1998) 原子力、今日そして明日:

Genshiryoku, kyō soshite ashita (Nuclear power, today and tomorrow).

October 1999 .

(1999) A newsletter about the 'Rinkai accident at JCO power plant', 15

(2002) 考えよう、原子力: Kangaeyō, Genshiryoku (Think about nuclear power).

Akaha, T. (1985) Japan in global ocean politics, University of Hawaii Press, Honolulu.

Akao, Ken-ichi (2002) "Private Forestry", in Y. Iwai (ed.) Forestry and the forest industry in Japan, USB Press, Vancouver, pp. 24 - 40.

Arai, Kikuo (2003) 'New business from recycling”, Asia Pacific Perspectives, vol. 1, no. 4, August, pp. $20-21$.

Araike, Manabu and Fujii Isao 赤池学・藤井 勲 (1998)「温もり」の選択: Yumori no sentaku (The choice for warmth), TBS Buritanika, Tokyo.

Asahi online news (2009) 'Midori no koyō, Kankyō shō ga teian (the Ministry of the Environment propose Green Employment)', 7 January, http://www.asahi.com/eco/TKY200901060337.html, (accessed 7 January 2009).

Asahi Shimbun 朝日新聞 (1999) 30 September (nuclear 34)

(1999) 1 October.

(1999) 3 October. 
(1999) 7 October.

(1999) 4 November.

(1999) 23 December.

(2000) 22 March.

(2000) 4 February.

(2002) 14 November.

(2002) "Whale meat imports to resume", The Asahi Shimbun, 6 March, http://www.asahi.com/english/national/K2002030600706.html, (accessed 6 March 2002).

(2003) 8 December.

(2005) 16 November.

(2008) 調査捕鯨、目標の 6 割どまりで帰港、妨害響くChōsa hogei, mokuhyō no rokuwari domari de kikō, bōgai tsuzuku (Research whalers return to Japan with a $60 \%$ catch, the disturbance continues), 15 April, http://www.asahi.com/special/070110/TKY200804150042.html, (accessed 22 April 2008).

(2008) Hogei bunka mamore, chihō gikai mo kokkai mo chōtōha de icchi danketsu 捕鯨文化守れ、地方外交も国会も超党派で一致団結 (Protect the whaling tradition, local government together with the central government collaborate on) (2008), 5 July, http://www.asahi.com/food/news/SEB200807050015.html, (accessed 21 May 2009).

Atomic Energy Commission, Administrative organizations for nuclear energy policy, http://www.aec.go.jp/jicst/NC/about/organizations.pdf, (accessed 23 January 2008).

(2002) 高レベル放射性廃棄物処分の「概要調査地区」の公募について:

Kō reberu hōshasei haikibutsu shobun no gaiyō chōsha chiku no kōbo ni tsuite (About public offering of outline of research district of high level radio active waste disposal), 24 December, http://www.aec.go.jp/jicst/NC/iinkai/teirei/siryo2002/siryo50/siryo3.pdf, (accessed 6 February 2008).

(2006) 平成 19 年度原子力経費関係経費概算要求額 Heisei 19 nendo

Genshiryoku kankē keihi gaisan yōkyū gaku (Requested budget for nuclear related estimates for 2007), 5 September,

http://www.aec.go.jp/jicst/NC/iinkai/teirei/siryo2006/siryo35/siryo2.pdf, (accessed 21 January 2008).

Attfield, Robin (2003) Environmental ethics, environmental problems and the ethics of science, http://www.ccels.cf.ac.uk/literature/publications/2003/attfieldpaper.pdf, (accessed 12 March 2007).

Australian (2009), “Cull considered for at-risk orcas", 11 May, p. 5. 
Baker, Scott and Clapham, Phillip (2005) "Appendix 1: Ethics of scientific whaling: issues and alternatives", Science, profit and politics: scientific whaling in the $21^{\text {st }}$ Century, a report by World Wide Fund for Nature (WWF), June, pp. $27-38$.

Bauer, Joanne (1992) The politics and ethics of global environmental leadership, 16 October, available at: http://www.cceia.org.resources/articles_papers_reports/967.html, (accessed 2 February 2007).

Barnaby, Frank and Burnie, Shaun (2005) Thinking the unthinkable, Japanese nuclear power and proliferation in East Asia, Oxford research groups and Citizen's nuclear information center.

Barrett, Brendan F.D. and Therivel, Riki (1991) Environmental policy and impact assessment in Japan, Routledge, London.

Beder, Sharon (1993) The nature of sustainable development, Scribe Publication Pty Ltd., Newham.

(2006) Environmental principles and policies: an interdisciplinary approach, University of New South Wales Press Ltd., Sydney.

(2006) Environmental principles and policies, UNSW Press, Sydney.

Befu, Harumi ベフ ハルミ (1987) イデオロギーとしての日本文化論 Ideorogī to shiteno nihon bunkaron (The theory of Japanese culture as an ideology), Shisō no Kagakusha, Tokyo.

(2001) Hegemony of homogeneity, an anthropological analysis of Nihonjinron, Trans Pacific Press, Melbourne.

Berry, Robert, J. (1993) “Appendix A: A code of environmental practice”, in Robert J. Berry (ed.), Environmental dilemmas, ethics and decisions, Chapman \& Hall, London, pp. $253-262$.

Bjorndal, Trond and Conrad, John (1998) “A report on Norwegian whale hunt", Marine Policy, vol. 22, no. 2, pp. $161-174$.

Bosshard, Peter (2005) "Introduction", in A Trojan Horse for large dams, how export credit agencies are offering new subsidies fro destructive projects under the guise of environmental protection, The Corner Hose, Environmental Defense, FERN, Friends of Earth Japan, the Halifax Initiative, International Rivers Network, Probe International, and the World Development Movement, published on September, the publication report was prepared by ECA WATCH.

Botzler, Richard and Armstrong, Susan (1998) Environmental ethics, Divergence and Convergence, $2^{\text {nd }}$ Edition, McGrow-Hill, Boston. 
Bowie, Norman (1990) "Morality, money, and motor cars" in M. Hoffman, R. Frederick and E. Petry, Jr. (eds.) Business, ethics, and the environment, the public policy debate, Quorum Books, New York, 1990, pp. 89 - 98.

Brazil, Mark (1992) “The wildlife of Japan: A $20^{\text {th }}$ Century naturalist's view”, Japan quarterly, July-September, vol. XXXIX, no. 3, pp. 328 - 338.

Brennan, Andrew (1993) "Environmental decision-making” in Robert, J. Berry (ed.), Environmental dilemmas, ethics and decisions, Chapman \& Hall, London, pp. 1 - 19.

Bromley, Daniel and Paavola, Jouni (2002) "Economics, ethics and environmental policy" in D. Bromley and J. Paavola (eds.), Economics, ethics and environmental policy, contested choices, Blackwell Publishers, Malden, MA, 2002, pp. 261 - 276.

Bullard, Monte (1974) “Japan's nuclear choice”, Asian Survey, vol. 14, no. 9, September, pp. $845-853$.

Callicott, J. Baird and Ames Roger T. (1989) "Epilogue: on the relation of idea and action", in J. B. Callicott and R. Ames (ed.), Nature in Asian traditions of thought: essays in environmental Philosophy, State University of New York Press, Albany, 1989, pp. 279 289.

Callicott, J. Baird (1994) Earth's insights, a survey of ecological ethics from the Mediterranean basin to the Australian outback, University of California Press, Berkerly.

Catalinac, Amy and Chan, Gerald (2005) "Japan, the West, and the whaling issue: understanding the Japanese side”, Japan Forum, vol. 17, no. 1 March, pp. 133-163.

Cavanaugh, Scott (2008) "Seeing the light", Japan Inc. , no. 80, 31 August, http://www.japaninc.com/mgz_september_2008 japanese-companies-changing-the-earth, (accessed 22 October 2008).

Cherfas, Jeremy (1989) The hunting of the whale, A tragedy that must end, Penguin books, London.

Chūō Nippō 中央日報 (2008) 日本環境産業のたえまない進化 “Nihon kankyō sangyō no taema nai shinka (Japan's environmental industrial market, endless progress)", 5 March, http://japanese.joins.com/article/article.php?aid=96951\&servcode=A00\&sectcode=A00, (accessed 24 February 2009).

Clammer, John (2001) Japan and its others, Globalization, difference and the critique of modernity, Trans Pacific Press, Melbourne.

Cochran, Charles and Malone, Eloise (2005) Public policy, perspectives and choices, $3^{\text {rd }}$ edition, Lynne Rienner Publishers, Colorado.

Commonwealth of Australia (1999) Industry and government energy delegation to Japan, Japan's energy future, dilemmas, policy targets and practicalities, industry science resources. 
Convention on International Trade in Endangered Species of Wild Fauna and Flora, http://www.cites.org/eng/disc/what.shtml, (accessed 9 April 2007).

Corliss, Mick (2001) "Recycling law lets producers off hook, taxes consumers: critics", The Japan Times, 21 March, available at: http://search.japantimes.co.jp/cgibin/nn20010321b1.html, (accessed 28 December 2007).

Corning, Gregory (2004) Japan and the politics of techno-globalism, M.E.Sharpe, Inc., New York.

Dai Nippon suisan kai 大日本水産会 (Japan Fisheries Association) http://www.suisankai.or.jp/daisui/zaimu/pdf/h18_report_3.pdf, (6 May 2008).

(2007) Rekishi 歴史 (History: Meiji - Heisei)

http://www.suisankai.or.jp/daisui/rekishi1.html, (accessed 8 August 2007).

(2007) Yakuin meibo 役員名簿 (Member's directory) July 2007,

http://www.suisankai.or.jp/daisui/zaimu/new pdf/yakuin.pdf, (accessed 6 May 2008)

(2008) Financial report between April 2007 - March 2008, http://www.suisankai.or.jp/daisui/zaimu/pdf/h19 plan_2.pdf, (accessed 7 May 2008).

Daly, Herman (1996) Beyond growth, the economics of sustainable development, Beacon Press, Boston.

Damveld, Herman. and Berg, Rovert Jan van den (2000) Nuclear waste and nuclear ethics, January, p. 15, http://www.nuclearfiles.org/menu/key-

issues/ethics/issues/scientific/nuclear_waste_ethics.pdf, (accessed 29 May 2008).

Danaher, Mike (1999) "Nature conservation, environmental diplomacy and Japan", Asian Studies Review, vol. 23, no.2, pp. $247-270$.

June, pp. $105-120$.

(2002) "Why Japan will not give up whaling”, Pacifica Review, vol. 14, no. 2,

Dauvergne, Peter (1997) Shadows in the forest, Japan and the politics of timber in Southeast Asia, Massachusetts Institute of Technology Press, Cambridge.

Des Jardins, Joseph (2001) Environmental ethics, an introduction to environmental philosophy, $3^{\text {rd }}$ edition, Wadsworth, Thomson learning, Belmont, CA.

Dicken, Peter and Miyamachi, Yoshihiro (1998) "“From noodles to satellites': the changing geography of the Japanese sogo shosha", Transactions the Institute of British Geographers, vol. 23, no.1, pp. 55 -78.

Dominichi, Gandolfo (2003) From business system to supply chain and production in Japan, http://www.unipa.it/gandolfodominici/Business-sys-SCM2003.pdf, (accessed 29 October 2007). 
Drifte, Reinhard (1990) Japan's rise to international responsibilities, the case of arms control, Atlantic Highlands Press, London.

Earth Summit in the United Nations homepage, http://www.un.org/geninfo/bp/enviro.html, (accessed on 4 January).

Eco 2006, report from the International Whaling Commission Annual Meeting, http://www.earthisland.org/immp/ECO2006/issue1.html, (accessed on 28 September 2006).

Earth Summit in the United Nations homepage, http://www.un.org/geninfo/bp/enviro.html, (accessed on 4 January).

Encarnation, Dennis (1999) "Introduction, Japanese multinationals in Asia" in Dennis Encarnation, Japanese multinationals in Asia, regional operations in comparative perspective, Oxford University Press, New York, pp. 3 - 16.

Energy Information Administration, official energy statistics from the U.S. government, (2006) http://www.eia.doe.gov/pub/international/iealf/tableh1co2.xls, (accessed on 4 April 2007).

Environment Agency (1999) 'Our intensive efforts to overcome the tragic history of Minamata disease'by Environment Health Department.

Environment White Paper 環境白書 (1972)

http://www.env.go.jp/policy/hakusyo/hakusyo.php3?kid=147, (accessed 18 February 2009). December 2007).

(1972) http://www.env.go.jp/policy/hakusho/img/147/tbx.1.gif, (accessed 5

(1977) http://www.env.go.jp/hakusho/hakusho.php3?kid=152, (accessed 30 October 2008).

(1980) http://www.env.go.jp/policy/hakusyo/hakusyo.php3?kid=155, (accessed 3 December 2007).

(1988) http://www.env.go.jp/policy/hakusho/hakusho.php3?kid=163, (accessed 3 January 2007).

(1989) http://www.env.go.jp/policy/hakusho/hakusho.php3?kid=201, (accessed 17 October 2008).

(1989) http://www.env.go.jp/policy/hakusyo/hakusyo.php3?kid=204, (accessed 21 October 2008).

(1993) http://www.env.go.jp/policy/hakusyo/hakusyo.php3?kid=205, (accessed on 5 January 2007).

(1994) http://www.env.go.jp/policy/hakusyo/hakusyo.php3?kid=205, (accessed 28 November 2007). 
(2007) http://www.env.go.jp/policy/hakusho/h19/index.html, (accessed 3 November 2008).

Evanoff, Richard. (1994) "Beyond 'cultural differences", Japan Environment Monitor, vol. 7, no. 2, \#62, June, p.3.

(1996) "Social Ecology: basic principles, future prospects. An interview with Murray Bookchin - part 1", Japan Environment Monitor, Issues \# 83, June, pp. 4 - 7.

Fairwood フェアウッド (2008) マレーシア、サラワク産木材、本当に「合法」です か? : Marēshia, sarawaku san mokuzai, hontō ni gōhō desuka (Is the timber from Sarawaku in Malaysia legitimite?). http://www.fairwood.jp/printdoc/prdc mel26 02.shtm1, (accessed 25 March 2009).

Fitzpatric, Stephen (2007) "Felled fro bio-fuel boom”, The Weekend Australian, 10-11 November.

FoE Japan, 森林プログラム: Shinrin puroguramu (Forestry program), http://www.foejapan.org/forest/trade/factsheet01.html, (accessed 29 October 2007).

Food and Agriculture Organization of the United Nations, http://www.fao.org/forestry/site/28679/en, (accessed 11 October 2007).

Forestry Agency 林野庁, 違法伐採対策: Ihō bassai taisaku (Illegal logging countermeasure), http://www.rinya.maff.go.jp/policy2/ihou/taisaku.html, (accessed 5 November).

, 関係法令: Kankei hōrei (Related laws), http://www.rinya.maff.go.jp/seisaku/houritu.html, (accessed 15 July 2008).

，森林・林業分野の国際的な取り組み: Shinrin, ringyō bunya no kokusai teki na torikumi (International contribution in forest and its industry), http://www.rinya.maff.go.jp/seisaku/sesakusyoukai/kaigi/con-3.html, (accessed 24 September 2007).

(2002) 地球恩だか防止森林吸収源 10 力年対策: Chikyū ondanka bōshi shinrin kyüshū gen 10 ka nen taisaku (A 10 year strategy to prevent global warming through forest absorption)", December, available at:

http://www.rinya.maff.go.jp/seisaku/sesakusyoukai/ondanka/10kanen-3.html (accessed 19 October 2007).

(2003) 森林と生活に関する世論調査: Shinrin to seikatsu ni kansuru yoron chōsa (Public opinion poll regarding forest and living), the Forestry Agency, December, available at: http://www.rinya.maff.go.jp/puresu/h16-3gatsu/0301 survey.htm, (accessed 17 October 2007).

(2003) 野生鳥獣による被害の害態と対策: Yaseichōjyū ni yoru higai no jittai to taisaku (Damage from wild animals and the counter measurements), 2003, 
http://www.rinya.maff.go.jp/seisaku/sesakusyoukai/mamoru/3.htm, (accessed 19 October 2007).

(2006) 平成 19 年度林野庁関係予算概算決定額の概要: Heisei 19nen do rinyachō kankei yosan gaisan kettei gaku no gaiyō (Related budget of the Forestry Agency 2007), December, http://www.rinya.maff.go.jp/puresu/h19-

2gatu/rinseisin/0205s1.pdf (accessed 25 September 2007).

(2006) 林産物需給と木材産業: Rinsanbutsu jukyū to mokuzai sangyō (Supply of forestry products and timber industry), http://www.maff.go.jp/j/wpaper/w_rinya/h19/pdf/data4-1.pdf, (accessed 24 March).

(2007) 森林ボランティアの現状: Shinrin boranthia no genjyō, (The current situation of forestry volunteers) the Forestry Agency, http://www.rinya.maff.go.jp/policy2/volunteer/con1.htm, (accessed 25 September 2007).

(2007) 林業 ・ 木材産業動向 Ringyō, mokuzai sangyō no dōkō (The trend of the forestry and timber industry), The Forestry Agency, 2007 http://www.maff.go.jp/hitokuti/memo/memo5 4.pdf, (accessed 28 September 2007).

(2007) 森林吸収目標達成に向けた平成 20 年度の対策について:

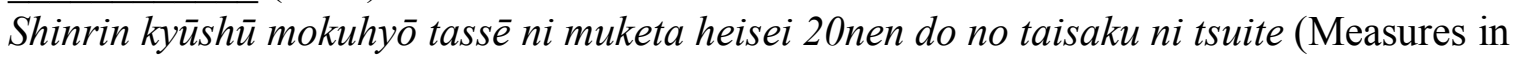
2008 aimed at countering carbon dioxide emissions through forestry absorbtion) http://www.rinya.maff.go.jp/policy2/h20yosan/h20jyuuten.pdf, (accessed 28 July 2008).

(2007) 我が国の取り組みについて: “Waga kuni no torikumi nit tsuite (Our country's strategy)", http://www.rinya.maff.go.jp/policy2/ihou/torikumi.html, (accessed 25 September 2007).

Forestry Agency White Paper 林業白書 (1989)

http://www.maff.go.jp/hakusyo/rin/h01/html/index/htm, (accessed 24 September 2007).

(2003) http://www.maff.go.jp/hakusho/rin/h16/html/r1050136.htm, (accessed 28 September 2007)

(2005) http://www.maff.go.jp/hakusho/rin/h18/html/data02.pdf, (accessed 27 September 2007).

(2006) http://www.maff.go.jp/j/wpaper/w rinya/h19/pdf/data4-1.pdf, (accessed 21 July 2008).

Frey, Bruno, S. (1999) "Morality and rationality in environmental policy", Journal of consumer policy, 22, 1999, pp. $395-417$.

Friedheim, Robert (1996) "Moderation in the pursuit of justice: explaining Japan's failure in the international whaling negotiations", Ocean development \& international law, 27, no.4, pp. $349-378$.

Fujitake, Ichiro (2002) "Forestry labour", in Y. Iwai (ed.) Forestry and the forest industry in Japan, USB Press, Vancouver, pp. $67-83$. 
Fujiwara, Mitsuo (2002) "Silviculture in Japan", in Y. Iwai (ed.) Forestry and the forest industry in Japan, USB Press, Vancouver, pp. 10 - 23.

Geishoku Labo 鯨食ラボ, http://www.gishoku-labo.co.jp/labo_1.html, (accessed 5 July 2007).

Geiniku kakaku to shokuniku kakaku no suihi 鯨肉価格と食肉価格 (A comparison of the price between whale meat and the other meat), http://www.maboroshich.com/ata/lif 12 3.htm, (accessed 21 April 2008).

Genshi nenryō seisaku kenkyūkai 社団法人原子燃料政策研究会 (Council for Nuclear Fuel Cycle, http://www.cnfc.or.jp/j/nuclear/index.html, (accessed 31 March 2009).

Genshiryoku 原子力 (Nuclear) 2002 (2002), The Agency of Natural Resources and Energy, the Ministry of Economy, Trade and Industry.

Genshiryoku, kyō soshite ashita 原子力今日そして明日 (Nuclear power, today and tomorrow) (1998), The Agency of Natural Resources and Energy, the Ministry of Economy, Trade and Industry.

Genshiryoku iinkai 原子力委員会 (1956), Nuclear White Paper 原子力白書, http://www.aec.go.jp/jicst/NC/about/hakusho/wp1956/sb10101.htm, (accessed 18 March 2007).

(1969), Nuclear White Paper 原子力白書, http://www.aec.go.jp/jicst/NC/about/hakusho/wp1969/sb1401.htm, (accessed 20 March 2008).

(1972), Nuclear White Paper 原子力白書, http://www.aec.go.jp/jicst/NC/about/hakusho/wp1972/sb2010201.htm, (accessed 27 March 2008).

(1982), Nuclear White Paper 原子力白書, http://www.aec.go.jp/jicst/NC/about/hakusho/wp1982/sb1010104.htm, (accessed 27 March 2008).

(1994), Nuclear White Paper 原子力白書, http://www.aec.go.jp/jicst/NC/about/hakusho/wp1994/sb1020901.htm, (accessed 28 March 2008).

Gillespie, A. (2000) "Whaling under a scientific auspice: the ethics of scientific research whaling operations", Journal of International Wildlife Law \& Policy, vol.3, no.1, Spring, pp. $1-49$.

Global environmental bureau in the Ministry of Environment (2005) “3R イ二シアティブ 閣僚会合について: 3R inithiatibe, kakuryō kaigō ni tsuite (Regarding the ministerial meeting of 3R initiatives)”, かんきょう: Kankyō (Environment), March, pp. 16-20. 
Global Environment Centre Foundation, http://www.gec.jp/gec/database/index-j.html, (accessed 11 March 2009).

Goghlan, Andy (1993) “The green empire”, The New Scientist, vol. 140, no. 1893, pp. 48 50 .

Goodin, Robert E. (1980) "No moral nukes", Ethics, vol. 90, no. 3, April, pp. 417 - 449.

(1982) Political theory and public policy, University of Chicago Press,

Chicago.

(1995) Utilitarianism as a public philosophy, Cambridge University Press,

Cambridge.

Greenpeace International, Illegal logging - destroying the last ancient forests, http://www.greenpeace.org/international/campaigns/forests/threats/illegal-logging, (accessed 5 November 2007).

Greenpeace Japan (2002) Press release, 23 April, http://www.greenpeace.or.jp/press/2002/20020423 html, (accessed 9 October 2006).

(2006) 違法伐採木材は輸入すべきではないと約 8 割が回答: Ihō bassai mokuzai wa yunyū subeki de wa nai to yaku hachi wari ga kaitō (About 80 percent agreed that Japan should no import illegally logged timbers), 24 April, http://www.greenpeace.or.jp/press/releases/pr20060424a html, (accessed 26 March 2009).

Gressor, J., Fujikura, K. and Morishima, A. (1981) Environmental Law in Japan, the MIT Press, Massachusetts.

Gunn, Alastair. (1994) "Can environmental ethics save the world?", in Frederick, Ferŕe and Peter, Hartel (eds.), Ethics and environmental policy, theory meets practice, The University of Georgia Press, Georgia, pp. $195-216$.

(2001) "Environmental ethics and trophy hunting", Ethics and Environment, vol. 6, no. 1, pp. $68-95$.

Haiyaku 配役 (Players) http://luna.pos.to/whale/jpn_bio_play.html, (accessed 27 July 2007).

Halliday, Jon and McCormack, Gavan (1973) Japan's imperialism today, Penguin Books, Harmondsworth.

Hara, Takeshi 原 剛 (1993) ザ・クジラ Za Kujira (The Whales), Bunshin do, Tokyo.

(1995) "The history, present situation and challenges of environmental

journalism", by the Japanese forum of environmental journalists, http://www33.ocn.ne.jp/ jfej/index-r.html, (accessed on 5 January 2007). 
Harada, Masazumi 原田正純 (2002) いのちの旅「水俣学」 の軌跡 Inochi no tabiMinamata-gaku he no kiseki (The path of life, traced through Minamata-Studies), Tokyo Shimbun Shuppan kyoku, Tokyo.

$$
\text { ,水俣の教訓から新しい学問への模索 Minamata no kyokkun kara }
$$

atarashii gakumon he no mosaku (Seeking a new study from the lessons of Minamata), http://www3.kumagaku.ac.jp/minamata/link/gaiyo/gaiyo-02.htm, (accessed 28 May 2007).

Harrison, R. (1999) “Jeremy Bentham", Honderich (ed.), The philosophers, Introduction to great Western thinkers, Oxford University Press, New York, pp. $122-129$.

Harsh, Bradley (1999) "Consumerism and environmental policy: moving past consumer culture”, Ecology Law Quarterly, vol. 26, no. 3, pp. 543 - 610.

Hatakeyama, Takemichi, Ōtsuka, Tadashi and Kitamura, Yoshinobu 畠山武道 ・大塚 直 ・北村嘉宣 (2003) 環境法入門 Kankyō ho nyūmon (Introduction to Environmental Law), Nihon Keizai Shimbun sha, Tokyo.

Hembery Rachel, Jenkins Anna, White George, and Richards Beatrix (2007) Illegal logging, cut it out!, The UK's role in the trade in illegal timber and wood products, by WWF UK in January, http://www.org.uk/filelibrary/pdf/logging_full_report01.pdf, (accessed 25 September 2007).

Hirata, Keiko (2004) 'Beached whales: Examining Japan's rejection of an international norm”, Social Science Japan Journal, vol. 7, no. 2, pp. 1 - 21.

Holland, A., Light, A., and O'Neill, J. (2008) Environmental values, Routledge, New York.

Hoshikawa, Jun 星川 淳 (2007) 日本はなぜ世界で一番クジラを殺すのか: Nihon wa naze sekai de ichiban kujira wo korosunoka (Why is Japan the highest killer of whales in the world?), Gentosha, Tokyo.

Hoshino, Yoshiro (1992) “Japan's post-second world war environmental problems”, in Jun Ui (ed.), Industrial pollution in Japan, United Nations University Press, Tokyo, pp. 64 76.

Igarashi, T. (1999) "Public works at crossroads", Social Science Japan, no. 17, December.

Illegal-logging info. (2004) Corruption often cause of environmental damage, 24 August, http://www.illegal-

logging.info/item single.php?item=news\&item id=458\&approach $\mathrm{id}=1$, (accessed 5 November 2007).

Ima kujira no minato wa いま、クジラの港は (What about whaling towns now?) (2001) Osakana Tsūshin; Gyo おさかな通信ギョッ (Fish correspondence; Fish), pp. 21 - 25.

Imai, K. (1980) “Japan's industrial organization”, Kazuo Sato (ed.), Industry and business in Japan, M.E. Sharpe Inc., New York. 
Imura, H. (2005) "Evaluating Japan's environmental policy performance", in H. Imura and M. Schreurs (eds.), Environmental policy in Japan, Edward Elgar, Northampton Massachusetts, pp. $342-359$.

(2005) “Japan's environmental policy: past and future” in H. Imura and M.

Schreurs (eds.), Environmental policy in Japan, Edward Elgar, Northampton Massachusetts, pp. $15-47$.

Ishi, Takaaki 石井孝明 (2004) 京都議定書は実現できるのか: Kyoto giteisho wa jitsugen dekiruno ka (Can the Kyoto Protocol be achieved?), Heibon sha, Tokyo.

International Whaling Commission, http://www.iwcoffice.org/commission/iwcmain.htm, (accessed 4 March 2007).

Commission,

"Scientific permit whaling - Iceland" by the International Whaling

http://www.iwcoffice.org/conservation/permits.htm, (accessed 1 September 2006).

'The IWC and scientific permits',

http://www.iwcoffice.org/conservation/permits.htm, (accessed 28 August 2006).

Alaska, May,

(2007) Chair's summary report of the $59^{\text {th }}$ annual meeting, Anchorage, http://www.iwcoffice.org/ documents/meetings/ChairSummaryReportIWC59rev.pdf, (accessed 4 March 2008).

(2007) Norwegian whaling 2006, Ministry of Fisheries and Coastal Affairs, Norway, 21 May, http://www.iwcoffice.org/_documents/commission/IWC59docs/59WKM\&AWI6.pdf, (accessed 23 April 2008).

Ishi, H, Okajima, S. and Hara, T. 石弘之 ・ 岡島成行 - 原 剛 (1992) 徹底討論地球環境 Tettei tōron, Chikyū kankyō (Debate on Global environment), Fukutake Shoten, Tokyo.

Ishi, Hiromitsu 石 弘光 (1999) 環境税とは何か Kankyō zei toha nanika (What is the environmental tax?), Iwanami Shoten, Tokyo.

Ishii, Takaaki 石井孝明 (2004) 京都議定書は実現できるのか Kyoto giteisho wa jitsugen dekiruno ka (Can the Kyoto Protocol be achieved?), Heibon sha, Tokyo.

Ito, Katsuhisa (2002) "Logging and log distribution", in Y. Iwai (ed.) Forestry and the forest industry in Japan, USB Press, Vancouver, pp.161 - 178.

Iwai, Hiromi 岩井宏實 (2002) 日本の神々と仏 Nihon no kamigami to hotoke (Japan's Gods and Buddha), Seishun Shuppan Sha, Tokyo.

Iwai, Yoshiya (2002) "Introduction", in Y. Iwai (ed.) Forestry and the forest industry in Japan, USB Press, Vancouver, pp. xiii - xx.

Iwai, Yoshiya and Yukutake, Kiyoshi (2002) "Japan's wood trade”, in Y. Iwai (ed.)

Forestry and the forest industry in Japan, USB Press, Vancouver, pp.244 - 258. 
Iwamoto, Junichi (2002) "The development of Japanese forestry", in Y. Iwai (ed.) Forestry and the forest industry in Japan, USB Press, Vancouver, pp.3 - 9.

Jain, Purnendra (1989) Local politics and policymaking in Japan, Commonwealth publishers, New Delhi.

(2000) "Jumin Tohyō and the Tokushima anti-dam movement in Japan, the people have spoken”, Asian Survey, vol. 40, no. 4, pp. 551 - 570.

(2005) Japan's subnational governments in international affairs, Routledge,

London.

Jamo, K. S. (1994) "Malaysian forest, Japanese wood, Japan's role in Malaysia's deforestation" in Jomo. K.S. (ed.), Japan and Malaysian development, in the shadow of the rising sun, Routledge, London, pp. $182-212$.

Japan External Trade Organization (2006) "Kankyō jūshi no shisei o tsuyomeru Nihon kigyō (Japanese companies who strengthen their stance on the importance of the environment)", http://www3.jetro.go.jp/jetrofile/BodyUrlpdfDown.do?bodyurlpdrf $=05001269001$ BUP 0.pdf, (accessed on 19 January 2007).

Japan Atomic Energy Commission (2005) 原子力関係予算: Heisei 18 nen do, Genshiryoku kankei yosan (Nuclear related budget for 2006), http://www.aec.go.jp/jicst/NC/about/hakusho/hakusho2006/siryo32.pdf, (accessed 4 February 2008).

Japan Atomic Industrial Forum, Inc. (2007) 日本の原子力産業の概要: Nihon no genshiryoku sangyō no gaiyō (Summary of Japan's nuclear power industry), October 2007, http://www.jaif.or.jp/ja/joho/press kit2007-sangyo.pdf, (accessed 4 June 2008).

(2008) 第 48 回〔2006 年度〕原子力産業実態調査の概要 Dai 48kai (2006) Genshiryoku sangyō jittai chōsa no gaiyō (Outline of research of Japan's nuclear power industry), 29 February 2008. The data is available at:

http://www.jaif.or.jp/ja/news/2008/48th-jittaichousa press-release.pdf, (accessed 4 June 2008).

(2007), Introduction to JAIF,

http://www.jaif.or.jp/english/news/2007/jaif brochure2007.pdf, (accessed 29 January 2008).

Japan Automobile Manufacturers Association, Inc. (2008) 2007 年度低公害車等の出荷 台数実績の公表について 2007 nendo teikōgaishatō no shukka daisū jisseki no kōhyō ni tsuite (Regarding a report on the 2007's low environmental pollution car shipment), 20 October, http://release.jama.or.jp/sys/news/detail.pl?item id=1346, (accessed 23 October 2008). 
Japan Bank for International Cooperation 国際協力銀行

http://www.jbic.go.jp/english/base/about/environ/index.php, (accessed 9 February, 2007).

Japan Fisheries Association 大日本水産会 (2006) 2007 年度低公害車等の出荷台数実 績の公表について Isarabi いさらび, no. 51, September, http://www.suisankai.co.jp, (accessed 7 August 2007).

Japan Times (2001) The Institute of Cetacean Research, "Whales are increasing as fish stocks decline", 23 July. This is an advertisement of the ICR.

(2006) “Japan's excessive fishing of southern tuna detailed”, 18 December.

Japan Times Online (2008) WTO proposal plagues farmers, 29 July,

http://search.japantimes.co.jp/cgi-bin/nb20080729a3.html, (accessed 25 March 2009).

Japanese Communist Party (2005) 研究開発費 Kenkyū kaihatsu hi (Research and development subsidy) in Akahata Shimbun, 29 August, http://www.jcp.or.jp/akahata/aik4/2005-08-29/2005082901_04_1.html, (accessed 22 January 2008).

Johnson, Chalmers (1991) MITI and the Japanese miracle, the growth of industrial policy, 1925-1975, The Charles E. Tuttle Company, Inc., Tokyo.

Johnston, Arthur and Needham, Stewart (1999) Protection of the environment near the Ranger uranium mine, Environment Australia, Supervising Scientist report 139, Canberra.

Johnston, E. (2000) "Monju ruling infuriates plaintiffs", Japan Times, 22 March, http://www.japantimes.co.jp/news/news3-2000/news3-22.html, (accessed 12 May 2000).

Kamiya, Mitsuo 神谷 満雄 (2003) “日本人がもつていた職業哲学: Nihonjin ga motte ita shokugyō tetsugaku (Occupational philosophy that Japanese have)”, 人間会議 Ningen kaigi, Winter, pp. 36 - 39.

Kaneko, Kumao (1996) "Japan needs no umbrella", The Bulletin of the Atomic Scientists, vol. 52, no. 2., March / April, pp. 46- 51.

Kankyō bengoshi gurūpu 'Chikyū' 環境弁護士グループ地球 (1999) 環境と法律を守ろ う Kankyō to Hōritsu, Chikyū wo mamorō (Environment and Law, Protect the earth), Hitotsubashi Shuppan, Tokyo.

Kankyō shimin 環境市民 (2007) 第 5 回日本の環境首都コンテスト Dai 5 kai Nihon no kankyō shuto kontesuto (The $5^{\text {th }}$ Japan's environmental capital contest), http://www.minamtacity.jp/jpn/kankyo etc/shuto_contest/contest.htm, (accessed 4 June 2007).

Kalland, Arne and Moeran, Brian (1992) Japanese whaling, end of an era?, Curzon Press Ltd., London. 
Koide, Hiroaki and Adachi, Akira 小出祐章・足立明 (1997) 原子力と共存できるのか: Genshiryoku to kyōzon dekiruka (Can we live together with nuclear power), Kamogawa shoten, Kyoto.

Katoh, Kunioki. 加藤邦興 (1977) 日本公害論: Nihon kōgai ron (The theory of Japanese kōgai), Aoki Shoten, Tokyo.

Katsuto, Naito 内藤克人 (2004) 「共生」経済への道〔2〕豊かな森が地域をはぐく む: "Kyōsei keizai he no michi (2), Yutaka na mori ga chiiki wo hagukumu (Path to coexistence with economy No.2, Rich forests enhance the community) "21 Seiki bijinesu juku (21 ${ }^{\text {st }}$ Century Business cram school), 23 April 2004, Nippon Hōsō Kyōkai (NHK), http://www.nhk.or.jp/business 21, (accessed 26 February2005).

Kawabe, Nobuo (1990) "Overseas activities and their organization" in Shinichi, Yonekawa (ed.), General trading companies: a comparative and historical study, United Nations University Press, Tokyo, pp.170 - 203.

Kawaguchi, Yoriko 山口順子 (2000) 国内での実績を作ることが日本の地球環境への 貢献となる “Kokunai deno jisseki wo tsukurukoto ga nihon no chikyū kankyō he no kōken to naru (Establishing an actual achievement will lead Japan to contribute to the global environment)”, 外交フォーラム Gaikō Fōramu, no. 146, October, pp. 10 - 11.

Kitoh, Sūichi (2003) 鬼頭秀一教授、恵泉女子大学（現：東京大学大学院）Keisen University, Faculty of Humanities. A personal interview with the author, 12 December 2003, Japan.

Knight, John (2005) 'Feeding Mr. Monkey: cross-species food 'exchange' in Japanese monkey parks", in John Knight (ed.), Animals in person, Berg, New York, pp. $231-254$.

Koga, Junichiro. 古賀純一郎 (2000) 日本を動かす財界シンクタンク: Keidanren, Nihon wo ugokasu zaikai shinkutanku (Keidanren, business circle think-tank who influences Japan), Shinchō sensho, Tokyo.

Koga, Katsujiro. 古賀勝次郎 (2003) 経済と道徳 - 企業家達の思想経済と道徳 - 企業 家達の思想 “Keizai to dōtoku - kigyōka tachi no shisō (Business and Morality entrepreneur's thoughts)”, 人間会議 Ningen kaigi (Human Conference), Winter, pp. 22 25 .

Komatsu, Masayuki. and Endō, Hisashi. 小松正之・遠藤久 (2002) 国際マグロ戦争 Kokusai maguro saiban (International tribunal for Southern Bluefin Tuna), Iwanami shoten, Tokyo.

Koshi shijō kasseika ni tsuite 古紙市場活性化について (Revitalization of waste paper market), available at http://seminar.econ.keio.ac.jp/shimada/paper/ap/ap-1.pdf, (accessed 10 October 2007). 
Kumamoto Gakuen University News letter 熊本学園ニュースレター (2001), 水俣学と は何か Minamata-gaku to wa nanika (What is Minamata-gaku?),

http://www3.kumagaku.ac.jp/minamata/link/gaiyo/gaiyo-01.htm, (accessed 28 May 2007).

Kyōdō Senpaku Kaisha Ltd. 共同船舶会社 (2006) “Changes in the shareholder composition", 24 March, http://www.icrwhale.org/eng/060324news.pdf, (accessed 12 May 2008).

Kyokuyo Co. Ltd. 株式会社 極洋, IR jyōhō IR 情報 (IR information), http://www.kyokuyo.co.jp/ir/result.html, (accessed 6 May 2008).

Lower House, the government of Japan (2008) 答弁本文情報 Tōben honbun jyōhō (Text of parliamentary reply), 1 February,

http://www.shugiin.go.jp/itdb shitsumon_pdf_s.nsf/html/shitsumon/pdfS/a169024.pdf/\$Fil e/a169024.pdf, (accessed 22 April 2008).

Lesbirel, Hayden (1998) NIMBY politics in Japan, energy sitting and the management of environmental conflict, Cornell University Press, Ithaca.

Manning, Robert (1995) "Rethinking Japan's plutonium policy: key to global Nonproliferation and Northeast Asian Security", the Journal of East Asian Affairs, vol. IX, no.1, Winter/Spring 1995, pp. 115 - 131.

Maruyama, Tokuji. 丸山徳次 (2003) 環境の豊かさを求めて - モデルとしての里山 "Kankyo no yutakasa wo motomete - moderu to shiteno Satoyama (To pursue for the healthy environment - Satoyama as a model)”, 人閒会議 Ningen kaigi, Winter December, pp. $204-207$.

McNeill, David (2008), "Justice Minister talkls in death-penalty riddles", Japan Times, 27 January, http://search.japantimes.co.jp/cgi-bin/fl20080127x3.html, (accessed 21 February 2008).

Matsushita, Kazuo 松下和夫 (2000) 環境政治入門: Kankyō seiji nyūmon (An introduction to environmental politics), Heibon sha, Tokyo.

Matsushita, Koji (2002) "National forest management", in Y. Iwai (ed.) Forestry and the forest industry in Japan, USB Press, Vancouver, pp. 84 - 117

Matsushita, Koji and Hirat, Kunihiro (2002) "Forest owner's association", in Y. Iwai (ed.) Forestry and the forest industry in Japan, USB Press, Vancouver, pp. $41-66$.

Maull, Hanns W. (1992) “Japan's global environmental policies”, in Andrew Hurrell and Benedict Kingsburry (eds.), The international politics of the environment, Clarendon Press, Oxford, pp. $354-372$.

McCormack, Gavan (1996) The emptiness of Japanese affluence, Allen \& Unwin, NSW. (2007) Client State, Japan in the American Embrace, Verso, London. 
McNeill, David (2007) "Japan and the whaling ban: siege mentality fuels 'sustainability' claims", Japan focus and Asia-Pacific e-journal, 13 February, http://www.japanfocus.org/products/details/2353, (accessed 5 March 2008).

Minamata city (2007) 水俣市、ごみの分別について Minamata shi, Gomi no hunbetsu nit tsuite (Minamata city, sorting out of rubbish), (2007), http://www.minamatacity.jp/jpn/kankyo_etc/gomi/gomi top.htm, (accessed 29 May 2007).

Ministry of Agriculture, Forestry and Fisheries 農林水産省 (2005) 林業関係基本指標: Ringyō kankei kihon shihyō (Basic indicator for forestry related issues), 2005, http://www.maff.go.jp/hakusho/rin/h18/html/sanko_01.pdf, (accessed 23 July 2008).

(2006) Media release on St. Kitts and Nevis, 19 June 2006 by Fisheries Agency. (2006) 鯨類調査捕獲事業費補助金 Geirui chōsa hokaku jigyōhi hojyokin (Subsidy on Cetacean research catch project) http://www.maff.go.jp/j/aid/hozyo/2006/suisan/pdf/21.pdf, (accessed 1 May 2008).

農林水産省 ODA 予算による取り組み Nōrin suisanshō ODA yosan ni yoru torikumi (Ministry of Agriculture, Forestry and Fisheries, dealing with ODA budget ), http://www.maff.go.jp/kokusai/cooperation/02/pdfl/data02-1-2.pdf, (accessed 25 March 2008).

(2007) 食糧自給率 Shokuryō jikyū ritsu (Self-sufficient rate on Food), http://www.maff.go.jp/j/tokei/sihyo/data/02.html, (accessed 23 March 2009).

(2008) 漁村地域力向上事業 Gyoseon chiiki ryoku kōjyō jigyō (Project for the revitalization of regional fishing) by Fisheries Agency, 2008, http://www.maff.go.jp/j/aid/hozyo/2008/suisan/pdf/25.pdf, (accessed 21 May 2008).

(2008) 漁村地域力向上事業 Gyoseon chiiki ryoku kōjyō jigyō (Project for the revitalization of regional fishing) by Fisheries Agency, 2008, http://www.maff.go.jp/j/aid/hozyo/2008/suisan/pdf/06.pdf, (accessed 21 May 2008).

(2008) 平成 21 年度水産予算概算決定の概要 Heisei 21 nendo suisan yosan gaisan kettei no gaiyo (The Fisheries detailed budget for 2009), December, http://www.jfa.maff.go.jp/j/budget/pdf/21kettei.pdf, (accessed 20 May 2009)

, Japan's whale research programs - Qs \& As, by the Institute of Cetacean Research, http://www.jfa.maff.go.jp/whale/document/Japan_research faq.htm, (accessed 5 September 2006).

, Whaling section, Fisheries Agency, Japan,

http://www.jfa.maff.go.jp/whale/index.htm, (accessed 1 July 2007).

Ministry of Economy, Trade and Industry 経済産業省 (2005) 日マレーシア経済連携協 定: Nichi Malaysia keizai renkei kyōtei (Japan-Malaysia economic partnership Agreement) 25 May, 
http://www.meti.go.jp/policy/trade policy/epa/data/malaysia JointPressStatement j.pdf, (accessed 29 October 2007).

(2007) 平成 20 年度経済産業省予算案の概要 Heisei 20nen do keizai sangyōshō yosanan no gaiyō (Outline of the budget of the Ministry of Economy, Trade and Industry in 2008), http://www.meti.go.jp/press/20071224001/01 yosan.pdf, (accessed 3 April 2008).

Ministry of Education, Culture, Sports, Science and Technology 文部科学省 (2006) 平成 19 年度概算要求主要事項 Heisei 19nen do gaisan yōkyū shuyō jikō (requested budget for main items for 2007), http://www.mext.go.jp/b_menu/houdou/18/08/06083104/012.htm, (accessed 25 January 2008).

Minister of the Environment 環境省 (1997) Environmental Impact Assessment Law, http:y//www.env.go.jp/en/laws/policy/assess/chap1.html, (accessed 29 November 2007).

(1969) Kōgai hakusho 公害白書 (Pollution White Paper),

http://www.env.go.jp/policy/hakusyo/hakusyo.php3?kid=144\&serial=11251\&kensaku=1\& word, (accessed 28 March 2008).

(1972) 環境白書 Environment White Paper

http://www.env.go.jp/policy/hakusyo/hakusyo.php3?kid=147, (accessed 18 February 2009).

(1972) 環境白書 Environment White Paper

http://www.env.go.jp/policy/hakusho/img/147/tbx.1.gif, (accessed 5 December 2007).

(1977) 環境白書 Environment White Paper

http://www.env.go.jp/hakusho/hakusho.php3?kid=152, (accessed 30 October 2008).

(1980) 環境白書 Environment White Paper

http://www.env.go.jp/policy/hakusyo/hakusyo.php3?kid=155, (accessed 3 December 2007).

(1988) 環境白書 Environment White Paper

http://www.env.go.jp/policy/hakusho/hakusho.php3?kid=163, (accessed 3 January 2007).

(1989) 環境白書 Environment White Paper

http://www.env.go.jp/policy/hakusho/hakusho.php3?kid=201, (accessed 17 October 2008).

(1989) 環境白書 Environment White Paper

http://www.env.go.jp/policy/hakusyo/hakusyo.php3?kid=204, (accessed 21 October 2008).

(1993) 環境白書 Environment White Paper

http://www.env.go.jp/policy/hakusyo/hakusyo.php3?kid=205, (accessed 5 January 2007).

(1994) 環境白書 Environment White Paper

http://www.env.go.jp/policy/hakusyo/hakusyo.php3?kid=205, (accessed 28 November 2007). 
(2007) 環境白書 Environment White Paper

http://www.env.go.jp/policy/hakusho/h19/index.html, (accessed 3 November 2008).

(1968), 公害白書 Kōgai White Paper

http://www.env.go.jp/policy/hakusho/honbun.pho3?kid=144\&bflg=1\&serial=11261, (accessed 20 February 2009).

(1970), 公害白書 Kōgai White Paper

http://www.env.go.jp/policy/hakusyo/hakusyo.php3?kid=145, (accessed 18 February 2009).

環境アセスメントガイド Kankyō Asesumento Gaido (Environmental Assessment Guide), http://www.env.go.jp/policy/assess/1-1guide/1-2.html, (accessed 29 November 2007).

法令 Hōrei (Law), http://www.env.go.jp/hourei/, (accessed 28 November 2007).

騒音 Sōon (Noise) in 法令 Hōrei， http://www.env.go.jp/hourei/sogo mokuji.php?mn=07, (3 December 2007)

(2000) Law for the recycling of specified items of home appliances (Home Appliance Recycling Law), http://www.env.go.jp/en/laws/recycle/08.pdf, (accessed 22 October 2008).

(2001) 21 世紀環境の世紀を迎えて、21seiki kankyō no seiki wo mukaete $\left(21^{\text {st }}\right.$ Century, the century for environment $)$, April.

(2002), 環境問題の関心 Kankyō mondai no kanshin (Interests for environmental issues), http://www.env.go.jp/policy/kihon keikaku/plan/tenken 02/koku pdf/03-2.pdf, (accessed 10 May 2007).

(2002), 環境問題に関する考え方 Kankyō mondai ni kansuru kangae kata (Thoughts about environmental issues), http://www.env.go.jp/policy/kihon_keikaku/lifestyle/h1610 01/03 3.pdf, (accessed10 May 2007).

http://www.env.go.jp/hourei/, (accessed 9 December 2007).

(2003), media report, 我が国の環境ビジネスの市場規模及び雇用の現状 と将来予想について ‘Wagakuni no kankyō biginesu no shijō kibo oyobi koyō kibo no genjyō to shōrai yosoku ni tsuiteno suikei nit suite (About the current and future in Market and employment scales of Japan's environment businesses)' 29 May, http://www.env.go.jp/press/press.php?serial=4132, (accessed 6 November 2008).

みなんでとめよう温暖化 “Minna de tomeyō ondanka”

(We do stop global warming)", http://www.env.go.jp/earth/ondanka/kokumin, (accessed 23 September 2006). 
(2004) Naze shinrin wo mamoranakereba naranainoka (Why do we need to protect forests?), the Ministry of Environment, 2004, http://www.env.go.jp/earth/shinrin/pamph/p05.pdf (accessed 19 October 2007).

(2005) 2005 年地球温暖化対策 2005 nen Chikyū ondanka taisaku (Climate change measures), http://www.env.go.jp/press/file view.php?serial=8615\&hou $\mathrm{id}=7603$, (accessed on 12 January, 2007).

(2005) International Environmental Cooperation toward sustainable development, Environmental Cooperation Office, Global Environment Bureau, 8 July, http://www.env.go.jp/earth/coop/coop/arikata j.html, (accessed 9 February 2007).

(2005) 2005 年度の温室効果ガス排出量速報值 2005 nen do no onshitsu kōka gasu haishutsu ryō sokuhyōchi (the amount of greenhouse gas emissions in Japan, 2005), http://www.env.go.jp/press/file-view.php?serial=8615\&hou id=7603, (accessed 12 January 2006).

(2007) 21 世紀環境立国戦略 21 seiki kankyō rikkoku senryaku (Strategy to be the Environmental State in the $21^{\text {st }}$ century), http://www.env.go.jp/guide/info/21c ens/21c strategy 070601.pdf, (accessed $11 \mathrm{March}$ 2009).

(2008) 環境白書 Environment White Paper http://www.env.go.jp/policy/hakusyo/h20/pdf/full.pdf, (accessed 10 March 2009).

Ministry of Finance 財務省 (2006) http://www.mof.go.jp/jouhou/syukei/h19/h180908.htm, (accessed 20 December 2007).

Ministry of Foreign Affairs of Japan 外務省 (2000) http://www.mofa.go.jp/policy/un/pamh2000_achieve/global.html, (accessed 2 January 2007).

(2001) “Japan's environmental ODA - strategy progress towards sustainable development", http://www.mofa.go.jp/policy/oda/category/environment/pamph/2001/oda.html, (accessed 12 September 2005).

(2003) 政府開発援助大綱について Seifu kaihatsu enjo taikō no kettei ni tsuite (Decisions of the Official Development Assistance), August, http://www.mofa.go.jp/mofaj/gaiko/oda/seisaku/taiko.html, (accessed 9 February 2007).

(2005) ODA Hakusho (2005 ODA White Paper), http://globalwarming.mofa.go.jp/mofaj/gaiko/oda/shiryo/hakusho/05 hakusho/ODA2005/h tml/zuhyo/index.htm, (accessed 7 October 2005).

(2005) セントビンセント 及びグレナディーン諸島: Sento binsento oyobi gurenadīn shotō (Saint Vincent and the Grenadines), The Ministry of Foreign Affairs, the government of Japan, http://www.mofa.go.jp/mofaj/area/svg/index.html, (accessed 15 September 2006). 
(1998) Diplomatic Bluebook of Japan,

http://www.mofa.go.jp/policy/other/bluebook/1998/I-d.html\#2, (accessed on 9 January 2007).

(2002) ヨハネスブルグサミット、小泉総理大臣内外記者会見

Yohanesu burugu samitto, Koizumi Souri daijin, Naigai kisha kaiken (Opening speech and interviews by the Prime Minister, Junichiro Koizumi at the Johannesburg Summit, 3 September 2002) http://www.mofa.go.jp/mofaj/gaiko/kankyo/wssd/koizumi speech.html, (accessed 12 January 2007).

(2005) 地球環境問題、国際環境協力と我が国の外交 Chiky $\bar{u} k a n k y \bar{o}$ mondai, kokusai kankyō kyōryoku to wagakuni no gaikō, http://www.mofa.go.jp/mofaj/gaiko/kankyo/pdfs/mon gaiko.pdf, (accessed 31 March 2007).

(2007) Japan - Malaysia Relations, November,

http://www.mofa.go.jp/region/asia-paci/malaysia/index.html, (accessed 2 January 2007).

, 違法伐採問題: Ihō bassai mondai (Illegal logging issues),

http://www.mofa.go.jp/mofaj/gaiko/kankyo/bunya/bassai.html, (accessed 5 November 2007).

Ministry of Internal Affairs and Communication 総務省 (2007) 着工新設住宅戸数:

Chakkō shinsetsu jyūtaku kosū (Number of new houses being built), available at:

http://www.stat.go.jp/data/nihon/g2109.htm, (accessed 5 October 2007).

(2008) the Statistics Bureau and the Director-General for Policy Planning, http://www.stat.go.jp/english/data/handbook/c05cont.htm\#cha5_2, (accessed 14 January 2009).

Mitsui Bussan 三井物産 (2008) 三井物産の森 : 森林の公益的機能: Mitsui Bussan no mori: Shinrin no kōeki teki kinō (Mitsui Cooperation's forest: The forests function for public benefit), http://www.mitsui.co.jp/csr/forest/function/index.html, (accessed 24 September 2009).

Mitsubishi Corporation, Global Network, http://www.mitsubishicorp.com/en/network/index.html, (accessed 25 October 2007).

Mitsubishi Shōji 三菱商事(2007) 会社情報 Kaisha jyōhō (Company information), http://www.mitsubishicorp.com/jp/about/index.html, (accessed 23 October 2007).

Mitsuhashi, Tadahiro 三橋規宏 (2002) 環境経済入門 Kankyō keizai nyūmon (Introduction to environmental economics), Nihon keizai shimbun sha, Tokyo.

Mitsui, Shoji (2002) "National and regional forest policies", in Y. Iwai (ed.) Forestry and the forest industry in Japan, USB Press, Vancouver, pp.145 - 160. 
Miyamoto, Kenichi 宮本憲一 (1989) 日本の環境政策: Nihon no kankyō seisaku (Japan's environmental policy), Ōtsuki Shoten, Tokyo.

Miyamoto, S. (1967) “The relation of philosophical theory to practical affairs in Japan", in C. Moore The Japanese mind, essential of Japanese philosophy and culture, University of Hawaii Press, Honolulu, pp. 4 - 23.

Morishita, Joji 森下丈二 (2001) “捕鯨問題の歴史的年表と将来の展望: Hogei mondai no rekishiteki nenyō to shōrai no tenbō (Historical transition of the whaling issue and its future: an analytical approach by a matrix)”, 国際漁業研究: Kokusai gyogyō kenkyu (Journal of International Fisheries), vol 4, no.1, March 2001, pp. 1 - 4.

(2002) なぜクジラは座礁するのか ? Naze Kujira wa zashou surunoka (Why are whales beaching?), Kawade Shobou Shinsha, Tokyo.

Mulgan, Aurelia (2000) The politics of agriculture in Japan, Routledge, London.

Nakamura, Hajime (1967) "Basic features of the legal, political, and economic thought of Japan", in Charles Moore (ed.), The Japanese mind, essential of Japanese philosophy and culture, University of Hawaii Press, Honolulu, pp. 143 - 152.

Nakamura, Y. (2006) “Keidanren lauds Abe's first 40 days in office”, Japan Times, 6 November, available at: http://search.japantimes.co.jp/cgi-bin/nb20061106jp.html, (accessed 9 December 2007).

Nelson, Gaylord (1980) "Earth Day '70: What it meant", EPA History, http://www.epa.gov/history/topics/earthday/02.htm, (accessed 30 April 2007).

Namba, Miho (2003) “Japan's recycling program”, Asia Pacific Perspectives, vol. 1, no.4, August, pp. $22-23$.

Nancho Consultations, http://www.nancho.net/advisors/anaes.html, (accessed 12 May 2007).

Nettairin kōdō netto wāku 熱帯林行動ネットワーク(Japan Tropical Forest Action Network), 違法伐採と日本の木材輸入: Ihōbassai to nihon no mokuzai yunyū (Illegal logging and Japan's timber import), http://www.jca.apc.org/jatan/pub/bookihou1.html, (accessed 5 November 2007).

New Energy and Industrial Technology Development Organization (NEDO), http://www.nedo.go.jp/introduing/about.html, (accessed on 10 April 2007).

http://app2.infoc.nedo.go.jp/kaisetsu/egy/index.html, (accessed 12 March 2009).

Nasu, Keiji 奈須敬二 (1990) 捕鯨盛衰記 Hogei seisuiki (The story of whaling's rise and fall), Kourin, Tokyo. 
Nevill, J. (2006) Ethics, fisheries, and marine protected areas, Working draft paper, 26 June, pp. $1-18$.

New Energy and Industrial Technology Development Organization, http://www.nedo.go.jp/introduing/about.html, (accessed 10 April 2007).

NHK 教育テレビテレビ (2006) 菅原文太長靴の旅、人とクジラがたどった道 ETV Sugawawa Bunta Nagagutsu no tabi, hito to kujira ga tadotta michi (A trip in wellington boots, a road passed by humans and whales by Sugawara Bunta), 22:00-23:30, 8 December.

Nihon bōeki kai (the Japan Foreign Trade Council, Inc.) 日本貿易会(財), 商社の活動: Shōsha no katsudō (Shōsha's activity), http://www.jftc.or.jp/shosha/activity/p02.html, (accessed 22 October 2007).

(2008) 商社業績表 (平成 2007 年 3 月決算),

http://www.jftc.or.jp/shosha/balancesheet/200703Shoshas-jpn.pdf, (accessed 24 October 2008).

Nihon mirai tanken tai (ed.) 日本未来探検隊 編 (1999) 原発天国のホントとウソ: Genpatsu tengoku no honto to uso (What is the truth or lies in Japan's nuclear power plants), Puranetto Shuppan, Tokyo.

Nihon Geirei Kenkyūjo 日本鯨類研究所 (The Institute of Cetacean Research), 日本鯨類 研究所の沿革と設立目的 Nihon geirui kenkyūsho no enkaku to setsuritsu mokuteki (History and establishment of the Institute of Cetacean Research), http://www.icrwhale.org/01-A.htm, (accessed 20 May 2009).

(2006) 2006 Revenue and expenditure report, data available: http://www.icrwhale.org/H18sushi.pdf, (accessed 12 May 2008).

(2007) 財産目録 Zaisan Mokuroku (Assets Details) as at 30 September 2007, data available at: http://www.icrwhale.org/H_18jigyo.pdf, (accessed 12 May 2008).

Nihon genshiryoku kenkyū hō 日本原子力研究法 (Japan nuclear power research law), May 1956, revised 2002, http://www.jaea.go.jp/jaeri/jpn/orga/05/pdf/jaeri-law.pdf, (accessed 19 March 2008).

Nihon hogei kyōkai 日本捕鯨協会 (Japan Whaling Association), http://www.whaling.jp/history.html, (accessed 1 August 2007).

Nihon keizai shimbun 日本経済新聞 (2004)「捕鯨」堂々と大儀を語れ Hogei dōdo to taigi wo katare ('Whaling' seek justice with dignity") 5 July.

Nihon Kyakkatten Kyōkai (The Association of Japan department store) 日本百貨店協会 (2005) “百貨店業界の ‘COOL BIZ と WARM BIZ' (Hyakka ten gyōkai no 'COOL BIZ to WARM BIZ' (Department store's 'Cool BIZ and 'Warm Biz')”, 環境 Kankyo, December, pp. $6-8$. 
Nihon Keizai Shimbun 日本経済新聞 (2004) 26 April. (footnote 59)

Nihonjinron 日本人論,

http://ja.wikipedia.org/wiki/\%E6\%97\%A5\%E6\%9C\%AC\%E4\%BA\%BA\%E8\%AB\%96, (accessed 23 May 2007).

Nihonjin no hinkaku, dōtoku kan ni kansuru chōsa kekka 日本人の道徳観に関する調査 結果 (Research on Japanese dignity and ethical perceptions) (2006),

http://research.goo.ne.jp/Result/000296, (accessed16 May 2007).

Nihon no genshiryoku 日本の原子力, http://www.fepc-atomic.jp/thumbnail/infobase/d-04.html, (accessed 7 January).

Nihon Ringyō Kyōkai 日本林業協会 (Japan Forestry Association), http://www.j-forestry.or.jp/teikan1.htm, (accessed 8 July 2008).

Nippon Keidanren 日本経団連 (2006) 日本経団連、日本経団連総会における御手洗 新会長就任挨拶 2006 年 5 月 24 日 Nippon Keidanren sōkai ni okeru miterai shin kaichō ni okeru Miterai shin kaichō shūnin aisats, 24 May 2006,

http://www.keidanren.or.jp/japanese/speech/20060524c.html, (accessed on 29 March 2007).

, About Nippon Keidanren,

http://www.keidanren.or.jp/english/profile/pro001.html, (accessed 7 December 2007).

(2007) 経団連ビジョン「希望の国、日本」Keidan ren bijon, 'Kibō no kuni, Nihon' (Keidanren's vision, dream country, Japan)

http://www.keidanren.or.jp/japanese/policy/2007/vision.html, (accessed on 29 March 2007).

(2007) 経団連の政策評価について Keidanren no seisaku hyōka ni tsuite (Regarding Keidanren's policy assessment), November, http://www.keidanren.or.jp/japanese/policy/2007/087.html, (accessed 9 December 2007).

Noda, Hideshi (2002) "The Japanese pulp and paper industry and its wood use", Y. Iwai (ed.), Forestry and the Forest Industry in Japan, UBC Press, Vancouver, 2002, pp. 214 229.

Notehelfer, F. G. (1975) “Japan's first pollution incident”, Journal of Japanese Studies, Vol., 1, No. 2, pp. 351- 383.

(1984) "Between tradition and modernity. Labor and the Ashio Copper Mine”, Monumenta Nipponica, vol. 39, no. 1, Spring, pp. 11 -24.

Nuclear and Industrial Safety Agency, NISA, 原子力安全・保安院 (2002), This is a government's brochure. 
Nuclear Control Institute, Washington D.C. (2002) "Japan can construct nuclear boms using its power plant plutonium", 9 April, http://www.nci.org/02NCI/04/pr040902.htm, (accessed 18 January 2008).

Nuclear energy national plan - main points and policy package September 2006, the Agency of Natural Resources and Energy, p. 2,

http://www.enecho.meti.go.jp/english/report/rikkokugaiyou.pdf, (accessed 9 January 2008).

Odin, Steve (1991) "The Japanese concept of nature in relation to the environmental ethics and conservation aesthetics of Aldo Leopold", Environmental ethics, vol. 13, no. 4, Winter, pp. $345-360$.

Ogi, Tamutsu (2002) "Home building and the home-building industry", Y. Iwai (ed.), Forestry and the Forest Industry in Japan, UBC Press, Vancouver, 2002, pp. 198 - 214.

Oishii kujira kyōshitsu おいしいクジラ教室 (Delicious whale meat cooking class), http://www.e-kujira.or.jp/topic/edu/06/0210/index.html, (accessed 16 April 2008).

O’Neill John, Holland Alan and Light Andrew (2008) Environmental values, Routledge, New York.

Organization for Economic Co-operation and Development (OECD) (2002) Environmental performance review on Japan, conclusions and recommendations, Paris-11 January.

(2005), science, technology and industry scoreboard 2005, briefing note for Japan, http://www.oecd.org/dataoecd/18/21/35471711.pdf, (accessed on 2 February 2007).

Observer (2006) "The son also rises in Japan”, Sunday 24 September.

Palmer, Clare (1997) Environmental ethics, Contemporary ethical issues, ABC-CLIO, Inc., California.

Paris Summit on international concerns about the environment (1989), Population and Development Review, vol.15, no. 3, September, pp. 583 - 587.

PBS Online forum, "Environmental diplomacy" analysis of the Kyoto Global Climate Conference, (1997) http://www.pbs.org/newshour/forum/december97/kyoto_12_12.html, (accessed on 28 August 2006).

Pempel, T. J. (1982) Policy and politics in Japan, creative conservatism, Temple University Press, Philadelphia.

Plumwood, Val (2002) Environmental culture, the ecological crisis of reason, Routledge, London.

"Politics at Stockholm: national foot-dragging" (1972), Science News, Vol. 101, No. 25, p. $\underline{390 .}$

Preston, Ronald H. (1987) The future of Christian ethics, SCM Press Ltd, London. 
Pulvers, R. (2007) "It was 40 (very different) years ago today....", Japan Times, 15 April, http://search.japantimes.co.jp/cgi-bin/fl20070415rp.html, (accessed 19 November 2007).

Pyle, Kenneth B. (1975) "Symposium: the Ashio Copper Mine pollution case:

introduction: Japan faces her future", Journal of Japanese studies, vol. 1, no.2, Spring, pp. $347-50$.

Rawls, John (1971) A Theory of Justice, The Belknap Press of Harvard University Press, Cambridge.

Rivers Watch East, Southeast Asia (RWESA) and, Friends of the Friends of the Earth Japan (2003 )Development and disasters, Japanese-funded dam projects in Asia, March.

Rix, Alan (1975) “Tokyo's governor Minobe and progressive local politics in Japan”, Asian Survey, vol. 15, no. 6, 1975, pp. $530-542$.

Roberts, Lewis (1993) “Case study: nuclear power”, in Robert James Berry (ed.), Environmental dilemmas: ethics and decisions, Chapman and Hall, London, pp. 86 - 103.

Routley, R. and Routeley, V. (1995) "Against the inevitability of human chauvinism", in R, Elliot (ed.), Environmental ethics, Oxford University Press, New York, 1995, pp. 86 - 103.

Samuels, R. (1994) Rich nation, strong army: national security and the technological transformation of Japan, Cornell University Press, Ithaca.

Schreurs, M. (2002) Environmental politics in Japan, Germany and the United States, Cambridge University Press, Cambridge.

Shibata, Tetsuji and Tomokiyo, Hiroaki 柴田鉄治・友清裕昭 (1999) 原発国民世論、世 論調査にみる原子力意識の変遷: Genpatsu kokumin yoron - Yoron chōsa ni miru genshiryoku ishiki no hensen (A public opinion poll for nuclear power-changes of nuclear awareness through an opinion poll), ERC Shuppan, Tokyo.

Shima, K. (1999) “Japan and whaling”, Social Science Japan, August 1999, pp. 3 - 6.

Shitahodo, Y. (1993) "The Japanese tradition of economic ethics", T. Dunfee and Y. Nagayasu (eds.), Business ethics: Japan and the global economy, Issues in business ethics, Kluwer Academic Publishers, Dordrecht, pp. 219 - 229.

Shikin no nagare 資金の流れ (money flows), http://luna.pos.to/whale/jpn bio money.html, (accessed 6 August 2007).

Shōji, Hikaru and Miyamoto, Kenichi 庄司光・宮本憲一 (1991) 日本の公害: Nihon no kōgai (Japan's environment pollution), Iwanami Shoten, Tokyo.

Singer, Peter (1995) How are we to live: ethics in an age of self-interest, Mandarin, Port Melbourne.

(1999) “George Wilhelm Friedrich Hegel”, in Honderich (ed.), The philosophers, Introduction to great Western thinkers, Oxford University Press, New York, pp. 130 - 137. 
Söderberg, M. (1996) “Japanese ODA - what type, the whom and why?", in M. Söderberg (ed.), The business of Japanese foreign aid, five case studies from Asia, Routledge, London, pp. $31-50$.

Sōgō shigen enerugī chōsakai kara no messēji 総合資源エネルギー調査会からのメッ セージ (message from the General Natural Resource Energy Investigation Committee) (2001), by the Agency of Natural Resources and Energy.

Sōjitsu kenzai kabushiki kaisha (Sojitz Building Materials Corporation) 双日建材株式会 社 (2007) 事業案内 :Jigyō annai (Our business), http://www.sojitzbm.com/business/index.html, (accessed 26 October 2007).

Stenmark, M. (2002) Environmental ethics and policy making, Ashgate Publishing Limited, Hants.

Sterba, J. (2005) "World Justice", Journal of Social Philosophy, vol. 36, no. 2, Summer, pp. $159-174$.

Stoett, P. (1997) The international politics of whaling, UBC Press, Vancouver.

水質保全法 Suishitsu Hozen Hō (Water Quality Conservation Law), available at: http://www.shugiin.go.jp/itdb housei.nsf/html/houritsu/03119581225181.htm, (accessed 16 November 2007).

Sugino, Mikio 杉野幹夫 (1990) 総合商社の市場支配: Sōgō Shosha no shijō shihai (Market monopoly of Sogo Shosha), Ōtsuki Shoten, Tokyo.

Sumi, Kazuo (1989) “The 'whale war' between Japan and the United States: problems and prospects”, Denver Journal of International Law \& Policy, vol. 17, no. 2, pp. 317 - 372.

Suwa, Yūzo 諏訪 雄三 (1998) 日本は環境に優しいのか: Nihon wa kankyō ni yasashii no ka (Is Japan kind to the environment?), Shinpyō Sha, Tokyo.

Suzuki, Maggie (1993) "Contradictions, ethics, and environmentalism in Japan", Japan environment Monitor, vol. 5, no. 8, \#50, January, pp. 12 - 13.

Takagi Fund (2004) http://www.takagifund.org/08/ui/ui01.html, 20 June (accessed 12 February 2007).

Takemura, Eiji (1997) The perception of work in Tokugawa Japan, University Press of America, Maryland.

Tamaru, Hirofumi 田丸博文 (1998) だから原発は危ない! Dakara genpatsu wa abunai! (That's why nuclear power plants are dangerous), Narusei Shuppan, Tokyo.

Tateno, Jun (2000) 灰炉時代が始まったーこの原発はいらない: Hairo jidai ga hajimatta, kono genpatsu wa iranai (Era when the extinction of nuclear power plants began, we don't need these plants), Asahi Shimbun sha, Tokyo. 
Taylor, Jonathan (1999) “Japan's global environmentalism: rhetoric and reality", Political Geography, 18, pp. 535 - 562.

Taylor, Vince (1982) "Living without nuclear energy", in M. Kaku and J. Trainer (eds.), Nuclear power, both sides: the best arguments for and against the most controversial technology, Norton, New York, pp. 155 - 159.

Thiele, L. (2000) "Limiting risks: environmental ethics as a policy primer", Policy Studies Journal, vol. 28, no. 3, pp. $540-557$.

Tsuru, Shigeto (1989) "History of pollution control policy", in Tsuru and Weidner (eds), Environmental policy in Japan, Edition Sigma, Berlin, pp. 15 - 42.

(1999) The political economy of the environment, the case of Japan, the Athlone Press, London.

Uni, Jun. 宇井純 (1989) 公害原論 Kōgai genron (Kōgai Principle), Aki Shobō, 1989.

(1992) "Minamata disease", in J. Ui (ed.), Industrial pollution in Japan, United Nations University Press, Tokyo, pp. $103-132$.

(1992) “Conclusions", in J. Ui (ed.), Industrial pollution in Japan, United Nations University Press, Tokyo, pp. $173-183$.

(1992) “Overview”, in J. Ui (ed.), Industrial pollution in Japan, United Nations University Press, Tokyo, pp. $1-17$.

，“21 世紀は自然と生活のための科学を: 21 seiki wa shizen to seikatsu no tame no kagaku wo (Science in the $21^{\text {st }}$ Century is existence with life)", Nelsis-Net, available at: http://www.nelsis.jp/nelsis/vol3/p12.htm, (accessed 19 November 2007).

Ui, Jun and Kitoh, Shūichi 宇井純・鬼頭秀一 (2006) 水俣に第三者はいない

“Minamata ni dai san sha wa inai (Minamata does not have the third party)”, 軍縮地球市 民: Gunshuku chikyū shimin, no. 6, Autumn, pp. 10 - 20.

United Nations Environment Program, UNEP (1992) "Rio Declaration on Environment and Development", June,

http://www.unep.org/Documents.Multilingual/Default.asp?documentID=78\&articleID=11 63 (accessed 29 May 2008).

United Press International (2005) "Japan's plutonium stockpile tops 43 tons", Physong.com, 8 September, http://www.physorg.com/news6316.html, (accessed 18 January 2008).

Upham, Frank (1987) Law and social change in postwar Japan, Harvard University Press, Cambridge. 
Urayasu city, Chiba prefecture, available at:

http://www.city.urayasu.chiba.jp/2000/2004/mukashi banashi/nepyo kaisetu.html, (accessed 16 November 2007).

Van de Veer, D. and Pierce, C. (1986) People, Penguins and plastic trees. Basic issues in environmental ethics. Wadsworth, Belmont, California.

Company, Belmont.

(1994) The environmental ethics and policy book, Wadsworth Publishing

Walker, Brett (2006) The lost wolves of Japan, University of Washington Press, Seattle.

Wapner, Paul (2000) "People, nature, and ethics", Current History, November 2000, vol. 00 , no. 640 , pp. $355-360$.

Washi no genryō 和紙の原料: Washi no genryō (Raw material of washi), available at http://hm2.aitai.ne.jp/ row/material/material.html, (accessed 9 October 2007).

Watsuji, Tetsurō 和辻哲郎 (1979) 和辻哲郎全集 Watsuji Tetsurō Zenshū (Collected works of Watsuji Tesurō), no.11, Iwanami Shoten, Tokyo.

2007).

(2004) http://plato.stanford.edu/entries/watsuji-tetsuro/, (accessed 11 May

Watsuji, Tetsurō and Furukuwa, Tetsushi (eds.) 和辻哲郎・古川哲史 (1977) 日本の文 化: Nihon no bunka (Japan's culture), Mainichi Shimbun-sha, Tokyo.

Water pollution control law, by the Ministry of Environment, Government of Japan, available at: http://www.env.go.jp/en/laws/water/wlaw/ch1.html, (accessed 19 November 2007).

Weekend Australian (1999) 9 - 10 October.

(2007) Japanese whalers go with no guard, 15 - 16 November.

(2000) 11-12 March 2000.

White, L. (1967) "The historical roots of our ecological crisis", Science, 155, available at: http://aece.org/resources/spiritual/rootsofcrisis.pdf, (accessed 15 February 2008).

Wolfson, R. (1995) Nuclear choices, revised edition, The MIT Press, Cambridge.

World Nuclear News (2007) "Mitsubishi to develop Japan's next fast breeder reactor", 18 April, http://www.world-nuclear-news.org/newNuclear/180407-

Mitsubishi to develop Japan's next fast breeder rector.shtml, (accessed 18 January 2008).

Worldwide number of ISO14001, http://www.ecology.or.jp/isoworld/english/analy14k.htm, (accessed 14 April 2007).

Xavier La Canna, "Most of whale kill pregnant", The Advertiser, 26 July 2007 
Yabe, Mitsuo 矢部三雄 (2002) 森の力、日本列島は森林博物館だ Mori no chikara, Nihon retto wa shinrin hakubutsukan da (The power of the forests, The Japanese archipelago is a forest museum), Kōdan-sha, Tokyo.

Yamaguchi, H. (2005) “Assessing the sustainability of Japan's foreign aid program: an analysis of development assistance to energy sectors of developing countries", Bulletin of Science, Technology \& Society, vol. 25, no. 5, October, pp. 412 - 425.

Yamamoto, W. (1994) "Japanese Official Development Assistance and Industrial Environmental Management in Asia", which was presented at the Nautilus Institute Workshop on Trade and Environment in Asia-Pacific, on September at Honolulu, http://www.nautilus.org/archives/papers/enviro/trade/odaasia.html, (accessed 12 February, 2007).

Yokkaichi kōgai, http://www.yokkaichikougai.tcup.ca/contents1/guide/1 zensoku/contents/preguidecss.htm, (accessed 26 November 2007).

Yomiuri shimbun 読売新聞オンライン (2004) 学校給食 50 年 Gakkō Kyūshoku 50 nen (School lunch for 50 years), 5 November, http://www.yomiuri.co.jp/kyoiku/special/s01/20041105tv01.htm, (accessed 11 July 2007).

(2006) 東芝、米 WH 買収を発表 Toshiba, bei WH baishū wo happyō (Toshiba report purchase of WH of USA), 7 February, http://www.yomiuri.co.jp/atmoney/mnews/20060207mh03.htm, (accessed 1 April 2008).

Yoshimoto, Tetsurō 吉本 哲郎 (2003) 小さな世界への回帰 “Chiisana sekai heno kaiki (The return to the small world)”, かんきょう: Kankyō, no.28, July, pp. 8 - 9. 